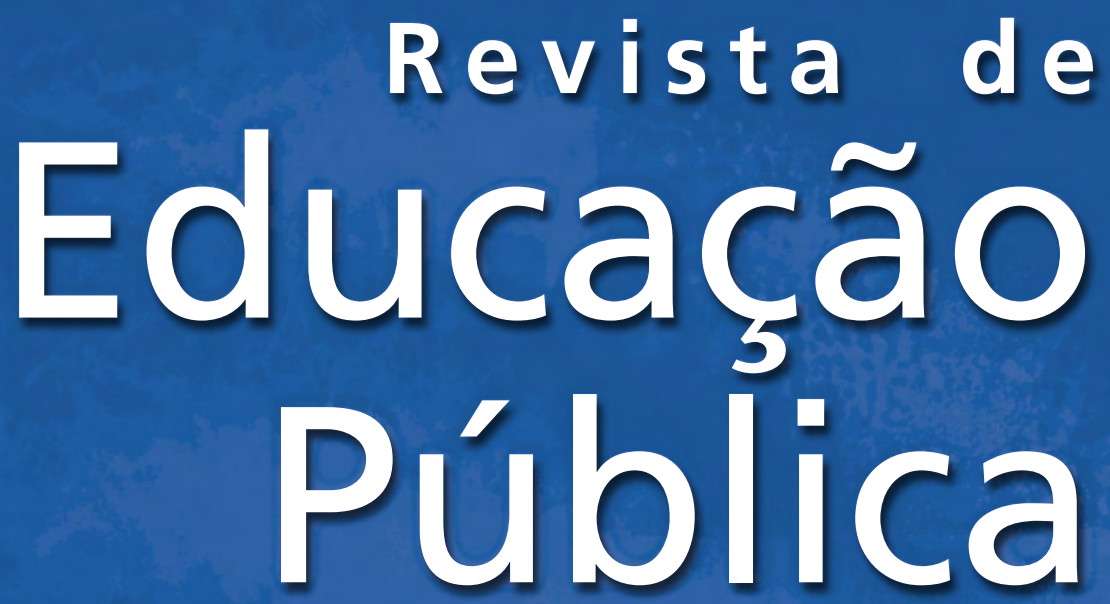

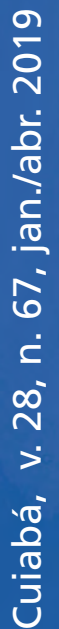


Reitora • Chancellor

Myrian Thereza de Moura Serra

Vice-Reitor • Vice-Chancellor

Evandro Aparecido Soares da Silva

\section{Coordenador da EdUFMT • EdUFMT's Coordinator}

Renilson Rosa Ribeiro

\section{Conselho Editorial • Publisher's Council}

Formula e aprova a política editorial da Revista;

Aprova o plano anual das atividades editoriais;

Orienta a aplicação das normas editoriais.

Bernard Fichtner - Universitat Siegen, Fachbereich 2 - Alemanha Bernardete Angelina Gatti - Fundação Carlos Chagas, São Paulo/SP, Brasil

Célio da Cunha - UnB, Brasília/DF, Brasil

Elizabeth Fernandes de Macedo - UERJ, Rio de Janeiro/RJ, Brasil Filomena Maria de Arruda Monteiro - UFMT, Cuiabál

MT, Brasil (editora geral)

Florestan Fernandes - In Memoriam

Francisco Fernández Buey - Universitat Pompeo Fabra, Espanha - In Memorian

José del Carmen Marín - Université de Genève, Suisse

Rute Cristina Domingos da Palma - UFMT, Cuiabá/MT, Brasil (editora adjunta)

Nicanor Palhares Sá - UFMT, Cuiabá/MT, Brasil

Paulo Speller - UFMT, Cuiabá-MT, Brasil

Conselho Consultivo • Consulting Council

Avalia as matérias dos artigos científicos submetidos à Revista.

Alicia Civera Cerecedo, Centro de Investigación y de Estudios Avanzados del Instituto Politécnico Nacional, México

Ana Canen - UFRJ, Rio de Janeiro, Brasil

Antônio Vicente Marafioti Garnica - UNESP/Bauru/Rio Claro, SP, Brasil

Alessandra Frota M. de Schueler - UFF, Niterói/RJ, Brasil Ângela Maria Franco Martins Coelho de Paiva Balça Universidade de Évora, Portugal

Benedito Dielcio Moreira - UFMT/Cuiabá, MT, Brasil Clarilza Prado de Sousa - PUCSP, São Paulo/SP, Brasil Claudia Leme Ferreira Davis - PUCSP, São Paulo/SP, Brasil Denise Meyrelles de Jesus - UFES, Vitória/ES, Brasil Dora Piñeres de La Ossa - Universidade de Cartagena - Colômbia Elizabeth Madureira Siqueira - UFMT, Cuiabá/MT, Brasil Geraldo Inácio Filho - UFU, Uberlândia/MG, Brasil

Héctor Rubén Cucuzza - Universidad Nacional de Luján, Província de Buenos Aires, Argentina

Helena Amaral da Fontoura - UERJ, Rio de Janeiro, Brasil Jader Janer Moreira Lopes - UFF, Niterói/RJ, Brasil Jaime Caiceo Escudero - Universidad de Santiago de Chile, Santiago, Chile Justino P. Magalhães - Universidade de Lisboa, Portugal
Ministério da Educação

Ministry of Education

Universidade Federal de Mato Grosso - UFMT

Federal University of Mato Grosso

Luiz Augusto Passos - UFMT, Cuiabá/MT, Brasil

Mariluce Bittar - UCDB, Campo Grande/MS, Brasil - In Memorian

Margarida Louro Felgueiras - Universidade do Porto, Portugal

Pedro Ganzeli - UNICAMP, Campinas/SP, Brasil

Rosa Maria Moraes Anunciato de Oliveira - UFSCar/São

Carlos, Brasil

\section{Conselho Científico • Scientific Council}

Articula as políticas específicas das seçôes da Revista; organiza números temáticos; e articula a comunidade científica na alimentação regular de artigos.

Nilce Vieira Campos Ferreira - UFMT, Cuiabá/MT, Brasil Educaçáo, Poder e Cidadania

Education, Power and Citizenship

Michèle Sato - UFMT, Cuiabá/MT, Brasil

Beleni Saléte Grando - UFMT, Cuiabá/MT, Brasil

Educação Ambiental

Environmental Education

Daniela Barros Silva Freire Andrade - UFMT, Cuiabá/

MT, Brasil

Educação e Psicologia

Education and Psychology

Kátia Morosov Alonso - UFMT, Cuiabá/MT, Brasil

Cultura Escolar e Formação de Professores

School Culture and Teacher Education

Elizabeth Figueiredo de Sá - UFMT, Cuiabá/MT, Brasil

História da Educação

History of Education

Marta Maria Pontin Darsie - UFMT, Cuiabá/MT, Brasil Rute Cristina Domingos da Palma - UFMT, Cuiabá/MT, Brasil Educação em Ciências e Matemática

Education in Science and Mathematics

Aceita-se permuta/ Exchange issues / On demande échange

\section{Endereço eletrônico:}

Sistema Eletrônico de Editoração de Revista (SEER): Open Journal Systems (OJS): <http://periodicoscientificos. ufmt.br/ojs/index.php/educacaopublica>

Revista de Educação Pública

Av. Fernando Corrêa da Costa, n. 2.367, Boa Esperança, Cuiabá-MT, Universidade Federal de Mato Grosso, Instituto de Educação, sala 101. CEP: 78.060-900 - Telefone: (65) 3615-8466 Email: rep@ufmt.br 


\section{Revista de Educação Pública}

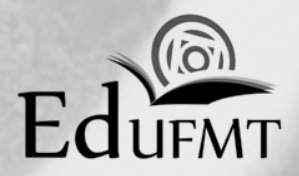

2019 
Copyright: (C) 1992 EdUFMT

Publicação articulada ao Programa de Mestrado e Doutorado em Educação da Universidade Federal de Mato Grosso

Av. Fernando Corrêa da Costa, n. 2.367, Boa Esperança, Cuiabá/MT, Brasil - CEP: 78.060-900 - Telefone: (65) 3615-8431

Homepage: <http://www.ufmt.br/ufmt/unidade/?l=ppge/>

\section{Missáo da Revista de Educaçáo Pública}

Contribuir para a divulgação de conhecimentos científicos da área de Educação, em meio às diferentes perspectivas teórico-metodológicas de análises, em tempos e espaços diversos, no sentido de fomentar e facilitar o intercâmbio de pesquisas produzidas dentro desse campo de saber, em âmbito regional, nacional e internacional, e assim, contribuir para o enfrentamento e debates acerca dos problemas da educaçấo brasileira em suas diferentes esferas.

Nota: A exatidáo das informaçóes, conceitos e opinióes emitidos nos artigos e outras produçóes sáo de exclusiva responsabilidade de seus autores. Os direitos desta ediçăo săo reservados à EdUFMT - Editora da Universidade Federal de Mato Grosso.

É proibida a reproduçáo total ou parcial desta obra, sem autorizaçáo expressa da Editora.

\section{EdUFMT}

EdUFMT Av. Fernando Corrêa da Costa, n. 2.367 - Boa Esperança. Cuiabá/MT - CEP: 78060-900

Homepage: <http://www.editora.ufmt.br/>. Email: <edufmt@hotmail.com>. Fone: (65) 3615-8322 / Fax: (65) $3615-8325$.

Editora Sustentável

(C) Site: <www.editorasustentavel.com.br>. Email: <editorasustentavel@gmail.com>. Fone: (65) 98159-9395.

Coordenador da EdUFMT: Renilson Rosa Ribeiro

Editora da Revista de Educaçáo Pública: Filomena Maria de Arruda Monteiro

Editora Adjunta: Rute Cristina Domingos da Palma

Técnica: Dionéia da Silva Trindade

Revisáo de texto: Maria das Graças Martins da Silva

Editoração eletrônica e finalizaçáo: Téo de Miranda - Editora Sustentável

Periodicidade: Quadrimestral

\section{Fontes de Indexaçáo:}

BBE - Bibliografia Brasileira de Educação (Brasil, Cibec/Inep/MEC)

$<$ http://pergamum.inep.gov.br/pergamum/biblioteca/index.php>.

Capes - Coordenação de Aperfeiçoamento de Pessoal de Nível superior - PERIODICOS.CAPES

<http://www-periodicos-capes-gov-br.ez52.periodicos.capes.gov.br/index.php?option=com_phome>

CLASE - Citas Latinoamericanas en Ciencias Sociales y Humanidades - Dirección General de Bibliotecas.UNAM

<http://132.248.9.1:8991/F/NUFM9L9KGCNIAJ8AS8T18UEEIDB8SC1BVMC8DLDD9673C3AKUE-10563? func=find-

-acc\&acc_sequence=000878343>

Diadorim - <http://diadorim.ibict.br/handle/1/375>

IBICT - Instituto Brasileiro de Informação em Ciência e Tecnologia - <http://www.ibict.br/>

IRESIE - Índice de Revista de Educación Superior y Investigación Educativa - UNAM

Universidad Autónoma del México - <http://132.248.192.241/-iisue/www/seccion/bd_iresie/>

LATINDEX - <http://www.latindex.unam.mx/buscador/resBus.html?opcion+2exacta+\&palabra=RevistaEducacaoPublica >

PKP - Public Knowledge Project - <http://pkp.sfu.ca/>

SciELO - EDUC@ - <http://educa.fcc.org.br/scielo.php?script=sci_serial\&lng=pt\&pid=2238-2097>

Sumários de Revistas Brasileiras - <http://sumarios.org/>

WebQualis - <http://qualis.capes.gov.br/webqualis/principal.seam>

\section{Catalogação na Fonte}

\section{R454}

Revista de Educação Pública - v. 28, n. 67 (jan./abr. 2019), Cuiabá,

EdUFMT, 2019, 256 p.

Anual: 1992-1993. Semestral: 1994-2005. Quadrimestral: 2006-

ISSN Eletrônico 2238-2097

1. Educação. 2. Pesquisa Educacional. 3. Universidade Federal de Mato

Grosso. 4. Programa de Pós-Graduação em Educação.

CDU37.050z

\section{Disponível também em:}

Sistema Eletrônico de Editoração de Revista (SEER): Open Journal Systems (OJS):

$<$ http://periodicoscientificos.ufmt.br/ojs/index.php/educacaopublica $>$

\section{Comercializaçáo:}

Correspondência para assinaturas e permutas:

Revista de Educação Pública, sala 101, Instituto de Educação/UFMT

Av. Fernando Corrêa da Costa, n. 2.367, Boa

Esperança, Cuiabá/MT - CEP: 78.060-900.

Email: <rep@ufmt.br>

\section{Fundaçấo Uniselva}

Caixa Econômica Federal / Agência 0686

Operação 003 / Conta Corrente 303-0

Assinatura anual: $\mathrm{R} \$ 55,00$

Exemplar avulso: $\mathrm{R} \$ 25,00$
Apoio:

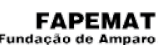

Fundação de Amparo

Pesquisa do Estado
de Mato Grosso

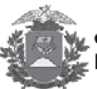
Mato Grosso
Este número foi produzido no formato $155 \times 225 \mathrm{~mm}$, em impressão offset, no papel Suzano Pólen Print $80 \mathrm{~g} / \mathrm{m}^{2}, 1$ cor; capa em papel triplex $250 \mathrm{~g} / \mathrm{m}^{2}, 4 \times 0$ cores, plastificação fosca em 1 face. Composto com os tipos Adobe Garamond e Frutiger. Tiragem: 300 exemplares

\section{Projeto Gráfico original:}

Carrión \& Carracedo Editores Associados Av. Senador Metello, 3773 - Cep: 78030-005 Jd. Cuiabá - Telefax: (65) 3624-5294 www.carrionecarracedo.com.br editoresassociados@carrionecarracedo.com.br 


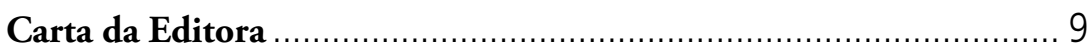

Cultura Escolar e Formaçã̃o de Professores .............................................. 13

Sentidos de qualidade: vozes de professores e

estudantes egressos da EJA no Ensino Superior ............................. 15

Caroline de Moura ROSA

Sita Mara Lopes SANT' ANNA

Odilon Antônio STRAMARE

Educação e Psicologia

A presença dos jogos de papéis na

Educaçáo Infantil

Maria Lidia Sica SZYMANSKI

Lisiane Gruhn COLUSSI

Pesquisa com crianças:

entre a experiência no campo e a escrita do texto

Irene Carrillo Romero BEBER

Maria Carmen Silveira BARBOSA

Educação, Poder e Cidadania

Diferenças, alteridade e

construçáo de valores inclusivos

Sandrelena da Silva MONTEIRO

Aquarela brasileira:

fantasmas melaninos, venenos melanômicos

Armando de Melo LISBOA

Educação Ambiental

Formaçáo continuada em Educaçáo Ambiental:

uma proposta em movimento

Raquel Fabiane Mafra ORSI

Antonio Fernando Silveira GUERRA 
História da Educação.

Cartas Sororales entre de dos mujeres intelectuales:

Palma Guillen y Gabriela Mistral

Oresta LÓPEZ PÉREZ

Reformas na educaçáo profissional brasileira na década de 1990:

consenso e hegemonia

Arão Davi OLIVEIRA

Celeida Maria Costa de SOUZA e SILVA

Educação em Ciências e Matemática

Ciência escolar e ciência fora da escola:

opinióes e interesses de jovens brasileiros

Graciela S. OLIVEIRA

Nelio BIZZO

Aprendizagem da docência na formação inicial de professores: estudar para ensinar matemática

Simone POZEBON

Anemari Roesler Luersen Vieira LOPES

Notas de leituras, resumos e resenhas

Educaçáo e Democracia: as liçóes da Finlândia para o Brasil

Camila EMÍLIO

Marineide de Oliveira GOMES

Informes da pós-graduação e da pesquisa

Seminário Educaçáo 2018: 30 Anos do Programa de Pós-graduaçáo em Educaçáo - Diálogos entre Políticas Públicas, Formaçáo de Professores e Educaçáo Básica

Filomena Maria de Arruda MONTEIRO

Relaçáo das defesas de Mestrado e Doutorado realizadas no PPGE/UFMT no período acadêmico 2018/2

Diretrizes para autores 252 
Contents

Editor letter

School Culture and Teacher Education

Senses of quality: the voices of teachers and

students coming from YAE in Higher Education.

15

Caroline de Moura ROSA

Sita Mara Lopes SANT’ ANNA

Odilon Antônio STRAMARE

Education and Psychology

The presence of role games in Early Childhood Education 41

Maria Lidia Sica SZYMANSKI

Lisiane Gruhn COLUSSI

Research with children:

between the experience in the field and the writing of the text

Irene Carrillo Romero BEBER

Maria Carmen Silveira BARBOSA

Education, Power and Citizenship 85

Differences, alterity and building of inclusive values 87

Sandrelena da Silva MONTEIRO

Brazilian Watercolor: melanin ghosts, melanomic poisons.

Armando de Melo LISBOA

Environmental Education

Continuing education in Environmental Education:

an action in movement

Raquel Fabiane Mafra ORSI

Antonio Fernando Silveira GUERRA 
History of Educacion

Sorority letters between two intellectual women:

Palma Guillén and Gabriela Mistral

Oresta LÓPEZ PÉREZ

The purpose of reforms in brazilian professional education in the 1990s: consensus and hegemony

Arão Davi OLIVEIRA

Celeida Maria Costa de SOUZA e SILVA

Education in Science and Mathematic

School and out-of-school science:

opinions and interests of young brazilians

Graciela S. OLIVEIRA

Nelio BIZZO

Teaching of learning in initial teacher education: need and sense of studying to teach mathematics 219

Simone POZEBON

Anemari Roesler Luersen Vieira LOPES

Reading's notes, summary and review

Education and Democracy: the learning of Finland in Brazil........241

Camila EMÍLIO

Marineide de Oliveira GOMES

Post graduation information and research development

Seminar on Education 2018: 30 Years of the Post-graduate Program in Education - Dialogue between Public Policies, Teacher Training and Basic Education

Filomena Maria de Arruda MONTEIRO

Relation of Masters and PhD defenses in the PPGE of academic period 2018/1

Submission Guidelines 252 


\section{Carta da Editora}

Estimados leitores e leitoras,

É com imenso prazer que apresentamos à comunidade acadêmica a primeira edição da Revista de Educação Pública do ano de 2019, com artigos que envolvem temáticas amplas e com representatividade institucional de vários autores, todos nas respectivas áreas e com suas devidas peculiaridades. Na sequência deste editorial, será possível encontrar contribuiçóes significativas que enriquecem o debate no campo da educação, por meio de pesquisas realizadas em âmbito nacional e internacional. Manteremos o trabalho que vem sendo realizado na revista nos últimos anos com o fluxo editorial aberto em demanda contínua, mesmo considerando o momento difícil pelo qual passamos no Brasil, com muitas incertezas quanto aos investimentos na produçáo do conhecimento nas universidades públicas.

Já estamos trabalhando na produção das próximas edições que compóem nosso número especial temático, articulado ao Seminário Educação - SEMIEDU, evento anual do Programa de Pós-Graduação em Educação, que este ano teve como temática os "30 anos do Programa de Pós-Graduação em Educação: Diálogos entre Políticas Públicas, Formação de Professores e Educação Básica”. Esta temática possibilita prever o potencial das reflexóes que integraram o referido evento, tanto na articulação dialógica entre as discussóes quanto na diversidade de conhecimentos a serem problematizados.

Trazemos aqui na apresentação deste editorial, trecho da conferência de abertura proferida por José González-Monteagudo como uma das reflexóes que teceu ao longo de seu texto, por considerar que este vem compor conosco, instigando nossa sensibilidade e entrelaçando-se às discussões dos demais artigos deste número a seguir,

[...] educación intercultural se construye con diálogo y encuentro compartido basado en el respeto y la valoración de alumnado, profesorado, familias, asociaciones y otros actores educativos, mediante una dinámica de participación y de diálogo.

É nesse contexto que o primeiro artigo Sentidos de qualidade: vozes de professores e estudantes egressos da EJA no Ensino Superior, trata os discursos sobre qualidade que veiculam nas escolas de Educação Básica da Modalidade de Educação de Jovens e Adultos e na Universidade presentes nos dizeres de professores e 
estudantes egressos da EJA. Evidencia nas vozes dos professores a qualidade na perspectiva neoliberal voltada ao ingresso no mercado de trabalho e nas vozes das acadêmicas egressas da EJA a predominância do discurso de qualidade social.

$\mathrm{O}$ artigo sobre $A$ presença dos jogos de papéis na Educação Infantil investiga se os jogos protagonizados ocorrem na Educação Infantil, por meio de análise do Projeto Pedagógico e de observação e anotaçôes em caderno de campo das atividades lúdicas de crianças de 5 a 6 anos. Ao identificar estes como uma oportunidade para realização dos desejos irrealizáveis que surgem na criança pré-escolar, reafirma-se que a escola necessita compreender e explorar as necessidades e criar incentivos, abrindo espaços e tempo na organização curricular para tais jogos.

Chamando a atenção para Pesquisa com crianças: entre a experiência no campo e a escrita do texto, o artigo propóe uma reflexão sobre o rico momento de estar com as crianças e ser desafiado a apreender os sentidos de suas açóes e a teorizaçáo do vivido, de explicitar e evidenciar o que foi aprendido. Esses momentos se complementam em uma aprendizagem contínua que nos instiga a novas aventuras de pesquisa.

Em sintonia com preocupações sobre Diferenças, alteridade e construção de valores inclusivos, problematiza-se as relaçóes estabelecidas com as diferenças nas interaçóes sociais e as implicaçóes do processo de desenvolvimento moral na construção de relaçóes de alteridade. Reafirmam que as relaçóes sociais constituem-se em um complexo processo de interação que propicia a modificação do sujeito em relação ao outro e a si mesmo.

As reflexóes contidas em Aquarela brasileira: fantasmas melaninos, venenos melanômicos, abordam a identidade racial, apontando para a importância crucial da desracialização da práxis política emancipatória para que ela possa alcançar êxito. Acrescenta que uma práxis negra antirracista deve romper com fechados identitarismos, num movimento de reinventar-se, conectar-se com o vir-a-ser humano "em companhia do homem, de todos os homens" (FANON, 1968, p. 274) ${ }^{1}$.

$\mathrm{O}$ artigo Formação continuada em Educação Ambiental: uma proposta em movimento parte da experiência vivida nas formaçóes continuadas de professores da Gerência de Educação de Itajaí-SC, para refletir sobre os elementos essenciais na formação continuada para ampliação da inserçáo da educação ambiental na escola. Assim, permitiu a construção de uma mandala de formação em EA, valorizando o Ser, o sentir e o agir, náo como gavetas desconectadas, mas em um movimento contínuo de fazer-refazer caminhos, pensar-repensar outros modos de reencantar a Educação.

1 FANON, F. Os condenados da terra. Rio de Janeiro: Civilização Brasileira, 1968. 
Em Cartas sororales entre de dos mujeres intelectuales: Palma Guillen y Gabriela Mistral, lança-se um olhar imerso no tecido epistolar como a figuração da irmandade entre duas grandes professorass latino-americanas: a escritora chilena e ganhadora do prêmio Nobel Gabriela Mistral e Palma Guillén, professora, diplomata e escritora mexicana, enfatizando as contribuiçóes da comunicação entre as mulheres, como representação sororal, enfrentando, às suas maneiras, a distância, a desesperança, a dor pessoal e as percepçóes do mundo na guerra que viveram.

Focalizando documentos da década de 1990 à luz dos conceitos de estado, de Gramsci (1991), acumulação flexivel do capital, de Harvey (1992), e trabalho, de Marx (1971) o artigo sob o título Reformas na educação profissional brasileira na década de 1990: consenso e hegemonia, reflete sobre as propostas e interesses do empresariado nacional e dos organismos internacionais na reforma da educação profissional brasileira.

Ciência escolar e ciência fora da escola: opinióes e interesses de jovens brasileiros, buscou-se as percepçóes de 2.404 estudantes matriculados no $1^{\circ}$ ano do Ensino Médio de 78 escolas sobre a ciência escolar e o interesse pela ciência fora da escola. Concluem que os estudantes reconhecem a importância das aulas de ciências e o seu papel no cotidiano, mas a proporção de interessados em aprofundar sobre temas científicos em outros espaços de informação é menor.

Nessa mesma linha o artigo Aprendizagem da docência na formação inicial de professores: estudar para ensinar matemática, apresenta resultados de uma pesquisa com acadêmicos de Licenciatura em Matemática e Pedagogia em um projeto desenvolvido com alunos do Ensino Fundamental em uma escola de rede pública estadual do Rio Grande do Sul. A partir dos episódios analisados ficou evidenciada a necessidade dos futuros professores de estudar o conteúdo a ser ensinado e o sentido atribuído por eles a essa ação.

Esperamos que os textos ora publicizados sejam um convite a manter nosso diálogo vivo e o desejo de seguir ampliando nossas problematizaçóes e formas outras de construir conhecimento juntos.

Filomena Maria de Arruda Monteiro Editora da Revista de Educação Pública Universidade Federal de Mato Grosso 



\section{Cultura Escolar e Formação de Professores}





\section{Sentidos de qualidade: vozes de professores e estudantes egressos da EJA no Ensino Superior

\author{
Senses of quality: the voices of teachers and \\ students coming from YAE in Higher Education
}

Caroline de Moura ROSA ${ }^{1}$

Sita Mara Lopes SANT' ANNA²

Odilon Antônio STRAMARE ${ }^{3}$

\begin{abstract}
Resumo
$\mathrm{O}$ artigo apresenta concepçóes de qualidade presentes nos dizeres de professores e egressos da Educação de Jovens e Adultos (EJA) no ensino superior. Para tanto, partindo dos estudos de Gadotti (2003), Gentili (1999) e Marques (2000) sobre a perspectiva neoliberal e social, promove-se pesquisa qualitativa, mediante pesquisa de campo, desenvolvendo entrevista semiestruturada com os participantes. Falas foram analisadas com base na Análise de Conteúdo, conforme (BARDIN, 2011). Como resultados, sobressaem-se nas falas dos professores a qualidade na perspectiva neoliberal voltada ao ingresso no mercado de trabalho. O discurso de qualidade social predomina nas falas das acadêmicas egressas da EJA.
\end{abstract}

Palavras Chave: Educação de Jovens e Adultos. Conceitos de Qualidade. Análise de Discurso.
Abstract

The article presents concepts of quality present in the words of teachers and graduates of Youth and Adult Education (known as YAE) in higher education. To do so, starting from the studies of Gadotti (2003), Gentili (1999) and Marques (2000) on the neoliberal and social perspective, qualitative research is promoted through field research, developing a semi-structured interview with the participants. Lines were analyzed based on the Content Analysis, according to (BARDIN, 2011). As a result, the teachers' speeches emphasize the quality of the neoliberal perspective aimed at entering the labor market. The discourse of social quality predominates in the speeches of the academic graduates of the YAE.

Keywords: Youth and Adult Education. Quality Concepts. Content Analysis.

1 Universidade Estadual do Rio Grande do Sul. Licenciada em Pedagogia pela Universidade Estadual do Rio Grande do Sul, em São Francisco de Paula. E-mail: <carolinerosa1996@hotmail.com>.

2 Doutora em Educação, pela Universidade Federal do Rio Grande do Sul - UFRGS (2009). Professora adjunta da Universidade Estadual do Rio Grande do Sul - UERGS, atuando nos cursos de Licenciatura em Pedagogia e Licenciatura em Letras na graduação e, também, no Mestrado Profissional em Educação. Líder do grupo de pesquisa do CNPq "Educação de Jovens e Adultos: docência, formação e processos pedagógicos da EJA", desde 2014. Reitoria: Endereço profissional: Rua Sete de Setembro, no 1156 Centro - Porto Alegre, Centro 90010191 - Porto Alegre, RS - Brasil. Telefone: (51) 32889034 URL da Homepage: http://www.uergs.edu.br E-mail: <sita-santanna@uergs.edu.br>.

3 Prof. Assistente da Universidade Estadual do Rio Grande do Sul, em Cruz Alta e São Francisco de Paula. E-mail: <straodin@yahoo.com.br>.

\begin{tabular}{|l|l|l|l|l|l|} 
R. Educ. Públ. & Cuiabá & v. 28 & n. 67 & p. $15-37$ & jan./abr. 2019 \\
\hline
\end{tabular}




\section{Introdução}

O presente artigo trata das concepçóes de qualidade presentes nos dizeres de professores do Ensino Médio, estudantes egressos da EJA que frequentam o ensino superior, bem como de professores-coordenadores de cursos que recebem alunos oriundos dessa modalidade, na universidade pública. Nessa perspectiva, busca-se investigar se a abrangência do conceito de qualidade veiculado nesses espaços contribui com os desejos e a permanência desses estudantes na universidade, visando saber também como esses acadêmicos, oriundos da EJA se percebem nesse contexto. Ao interpretar o conceito de qualidade na perspectiva da composiçáo de melhorias no sentido de atender as necessidades, considerando a satisfaçáo de todos os participantes do processo educativo e pela responsabilização de suas partes, entende-se que esse é um tema a ser discutido, ampliado e refletido de forma constante. Embora sejam encontradas inúmeras citaçôes do termo "qualidade" em múltiplos documentos - desde a própria legislaçáo educacional vigente no Brasil - suas concepçóes e contextos de realidades se diferem significativamente.

Visando compreender esse quadro, a metodologia aplicada parte dos pressupostos da pesquisa qualitativa e de cunho descritivo. Para tanto, efetivou-se levantamento bibliográfico, tendo por foco estudos sobre o conceito de qualidade e suas bases legais e, ainda, no que tange às políticas educacionais e as implicaçóes da influência do Banco Mundial e Fundo Monetário Internacional para as políticas públicas, reforçando concepçóes de qualidade neoliberal em confronto com as de qualidade social em educaçáo, também presentes nesses cenários. Esta investigaçáo tem como instrumento de coleta de dados entrevistas registradas em áudio e realizadas mediante agendamento com os participantes, nas dependências da universidade pública localizada no Rio Grande do Sul. Em seguida, foram feitas análises das falas coletadas a partir de orientações da Análise de Conteúdo, com base nos estudos de Bardin (2011), considerando que as trajetórias desse processo foram se constituindo na medida em que a interpretação possível de seu conteúdo foi sendo mobilizada.

\section{O conceito de qualidade e algumas bases legais em educação}

Qualidade é um termo dinâmico e está sempre se remodelando. Advinda do latim qualitate, em concordância com o Novo Dicionário Aurélio (FERREIRA, 1999, p. 1675), significa: "Numa escala de valores, qualidade que permite avaliar e, consequentemente, aprovar, aceitar, ou recusar qualquer coisa [...] Categoria 
fundamental do pensamento que designa os modos diversos como as coisas são". Considerando na conformidade generalizada, se perfaz no posicionamento de quesitos e critérios que auxiliam na melhoria de um ideal ou situação, que não esteja resultando da maneira correta ou, minimamente, propícia. Segundo Garvin (2002, p. 57), esta palavra é sinônima do conceito de "desenvolver, projetar, produzir e 'comercializar' um produto ou ideologia que seja mais econômico e facilitador para a população que irá usufruir deste recurso, sendo mais útil e sempre satisfatório". Também se definem como características essenciais, a propriedade, o traço pessoal, o caráter, a natureza, a espécie, o tipo, e a excelência. Para Marques (2000, p. 116), a qualidade da educaçáo pode ser vista no sentido técnico-instrumental referindo-se "as características ou fatores que contribuem para a eficácia do ensino, ou seja, para levar a bom termo a missão e os objetivos da organizaçáo". No sentido axiológico, conforme o autor, estar-se-ia referindo-se ao "valor intrínseco e à essência do ensino".

Dessa forma, o pensamento sobre a palavra qualidade passa a remeter a um cuidado e traz à tona críticas acerca da educaçáo e de seus indicadores de qualidade, estes táo veiculados na atualidade e que seriam responsáveis por avaliar o sistema em conformidade com o que se exige para que a educação tenha um valor equalizado, ou seja, de igual proporçáo ou dimensáo a todos que dela participam, reforçando, ainda, epistemologias que englobam este grande círculo: o da qualidade única e geral do ensino de um país, externalizando-a por conta de comparaçóes com os demais sistemas educacionais. Essa concepçáo de qualidade insiste no ideal de que, não simplesmente são frutos de pseudo-ditaduras na medida em que um ou mais governos promovem para que os envolvidos as sigam, mas sim, veladamente, estipulam uma série de fatores que, regrados e organizados de modo transparente, trabalham pelas melhorias, que em muitos casos, ficam apenas no papel.

O Brasil da atualidade remete-se, sempre, à lógica de comparação com os países mais desenvolvidos, visto que há um investimento na área, advindo de órgãos externos; tendo como título exemplar o Banco Mundial. Neste entendimento é imprescindível que sejam avaliadas as instituiçóes de ensino com intuito de obtenção de melhores índices e resultados, criando padróes que devem ser seguidos por todas. Tais padróes, como indicadores, se encontram distribuídos entre as leis do país, de forma explícita, na tentativa de que sejam reconhecidos.

Especificamente, na modalidade de Educação Básica, como se confere a Educação de Jovens e Adultos, os principais precedentes do significado da palavra em questão, estão promulgados em muitas leis e pareceres estabelecidos para a educação em geral e, também, para essa em particular. As políticas de estado e governos têm evidenciado a exigência de um padrão de qualidade a ser alcançado 
e claro, o mesmo segue instituído por ideais, trazendo consigo os mecanismos de "aferição" deste nível que são difusos na perspectiva de contribuir com o acesso e permanência dos estudantes, estejam eles em qualquer um dos níveis de ensino.

$\mathrm{Na}$ década de 80 ressurge o debate beneficiando o direito à educação. Esse movimento, ocorrido no fim da ditadura militar, principalmente caraterizado pela falta de democracia, supressão de direitos constitucionais, censura, perseguição política e repressão aos que eram contra esse regime, desencadeou, na segunda metade da década, a luta que buscava acesso e, posteriormente, a ampliação da escola pública com qualidade para atendimento em todas as instâncias educacionais formais. De acordo com os debates, houve circundantes modificações nas leis brasileiras, a se observar pela Constituição Federal de1988, que trouxe avanços significativos em termos jurídicos, introduzindo o ponto de vista de direito público e social. No sentido educativo, há alta gama de concepçóes sobre a educação, tratando-a como dever fundamental do estado e da família para o exercício da cidadania. Já na Constituição consta o primeiro indício do termo qualidade para a implantação de padróes determinados e, da mesma forma, de efetiva realização de um Plano Nacional de Educação, principiando melhorias. Dispondo como base a própria Constituição Federal de 1988, intercepta-se no inciso sétimo do Artigo 206, a afirmação de que o ensino será ministrado com garantia de padrão de qualidade. E cabendo no mesmo segmento a explicitaçáo de como o procedimento deve ser efetuado perante a prática, do mesmo modo como incita e assegura "oportunidades educacionais igualitárias" mediante assessoria de recursos provenientes dos regentes. A esse respeito, assim se manifesta a referida Constituição em seu Artigo 211, $\$ 1^{\circ}$ :

A União [...]financiará as instituiçóes de ensino públicas federais e exercerá, em matéria educacional, função redistributiva e supletiva, de forma a garantir equalização de oportunidades educacionais e padrão mínimo de qualidade do ensino mediante assistência técnica e financeira aos Estados, ao Distrito Federal e aos Municípios. (BRASIL. Constituição Federal, 1988).

Nesta perspectiva tem-se um indicativo de que o Brasil mantém pressupostos regidos por lei de melhorias constantes na educação, tendo apenas a progredir com os alunos mediante normas vigentes regularizadas. Ainda, dentro das especificaçôes pertinentes do bloco educacional, a implantação da EJA como modalidade de Ensino da Educação Básica faz com que a qualidade se mantenha presente como quesito de suma importância. Estas reformas propositam padróes 
mínimos de qualidade conferidos, conforme Carreira (2013, p. 22-23), como ambiente escolar em boas condiçóes de utilização, com recursos disponíveis aos professores e alunos; a própria docência; promoção do acesso à informação; apoio educacional; alimentação; saúde e higiene; promoçáo da convivência; suporte pedagógico à docência; administração; manutenção, conservação e segurança, bem como a integração com a sociedade, quesitos estes, retirados de um manual característico do Fundo Nacional de Desenvolvimento da Educação, que os específica como insumos mínimos.

A Lei de Diretrizes e Bases da Educação Nacional, nº 9.394 (BRASIL, 1996) refere-se à qualidade de modo que:

Art. 3o $\mathrm{O}$ ensino será ministrado com base nos seguintes princípios: [...] IX - garantia de padrão de qualidade; [...] Art. 4o $\mathrm{O}$ dever do Estado com educação escolar pública será efetivado mediante a garantia de: [...] IX - padróes mínimos de qualidade de ensino, definidos como a variedade e quantidade mínimas, por aluno, de insumos indispensáveis ao desenvolvimento do processo de ensinoaprendizagem. (BRASIL, Lei de Diretrizes e Bases, $\mathrm{n}^{\circ}$ 9394/96).

Em segmentos educativos, esta lei especifica que os padróes de qualidade existem, não esclarecendo quais são, pois, eles dependem da governabilidade imposta, entretanto, foram propostos inicialmente, a partir de longas discussóes acerca do tema. Desde que a EJA foi anunciada como uma das modalidades da Educação Básica, encontra-se submersa nos discursos de que há padróes educacionais gerais que devem ser seguidos, assim como farão os níveis e demais modalidades expressas pela legislação.

Os indicadores ${ }^{4}$ que a própria $\mathrm{LDB}$ menciona em vários de seus artigos pressupóem buscas sobre o que acontece, de fato, no cotidiano escolar, como atenção às quantidades de alunos atendidos; insumos necessários ao desenvolvimento do processo de ensino-aprendizagem (com referência nos citados do Fundo Nacional de Desenvolvimento da Educação - FNDE, 2013, publicados no site oficial); avaliação do processo nacional de rendimento escolar; cálculo sobre o custo do aluno, enquanto estudante de escola pública; etc. Saber o que todas essas

4 Indicador, de acordo com Marques (p. 57, 2000) significa a análise e avaliaçăo das organizaçóes escolares e das políticas educativas recorrentes à informação estatística, levando em conta um conjunto de características consideradas significativas para medir o impacto da educação. 
demandas significam passa a ser uma questão essencial. Havendo entendimento sobre qualidade, como uma série de intervençóes que servem para promoçáo de uma melhoria significativa, existe a necessidade básica de mecanismos que defendam e garantam esse pressuposto de extrema importância para o ensino congruente com o que se deseja ofertar.

Conforme as dimensóes ainda tratadas no livro de Usos dos Indicadores de Qualidade, dispóe-se a parte de processos, que é uma atençáo voltada às ações continuadas em questáo de formaçáo para professores, gestáo democrática na qual toda a comunidade escolar possa participar, de forma democrática, das políticas curriculares que regem os conteúdos, metodologias e avaliaçóes de aprendizagem totalmente transparente e acessível, buscando, inclusive, parcerias como sistema de ação conjunta, auxiliando umas às outras a se readequarem conforme os padróes/ indicadores mínimos de qualidade. Como último advento deste é possível encontrar o trabalho que seria desenvolvido com equidade, que cumpre com a premissa de superar todas as discriminaçóes e desigualdades, incluindo e integrando pessoas de quaisquer gêneros, renda, etnia, raça, religiáo, entre outros meandros pertinentes da sociedade. Propositando ser essa a escola de qualidade, são necessárias muitas transiçóes que atravessaráo a realidade que se encontra nessa instituição.

Diante do conceito substancial de qualidade, percebe-se esta como medidas de aprimoramento de determinada situação ou ambiente que esteja precisando passar por uma transformação, para que seus envolvidos fiquem satisfeitos e, como na situaçáo da educaçáo, obtenham um bom ensino que os permitam prosseguir com suas carreiras, dando-lhes oportunidades igualitárias e acesso aos que dela precisam.

\section{Qualidade: educação neoliberal e educação social}

Permeada por um processo característico e num discurso igualitário e "para todos”, a educação neoliberal, desde os primórdios da sociedade, é excludente; compreende os sujeitos como produtos da construção da livre concorrência, da ação dos mais hábeis, eficientes e eficazes, cujas credenciais, na verdade, são decorrentes da mercadologia a qual estão inseridos. Em processos educacionais esta concepção neoliberalista transforma as pessoas em instrumentos das lógicas de mercado e do trabalho. A estratégia utilizada em "cursos" neoliberais se embasa na manipulação do afetivo, sentimentos e desejos individuais, através do convencimento publicitário, não permitindo que circulem visóes alternativas às lógicas estabelecidas. Isso significa que, permeando a noção de igualdade, a proposta dá espaço para a redefiniçẫo de produtividade, qualidade e modernidade, 
não existindo aberturas para novas ideias. O que permanece, de fato, é a utilização de uma metodologia indutiva que auxilia o processo de dar regalias a quem se sobressai e muitos planos de carreira de docentes que atuam nessa lógica, operam com a meritocracia que gera individuais avanços progressivos e pecuniários.

$\mathrm{Na}$ construção da educação social proposta por Gadotti (2003) cada pessoa tem seu potencial. No intuito de explorar esses quesitos e aprimorá-los a fim de trazer uma contribuição socioeducativa, Gadotti (2003, p. 9) enuncia que, em um tempo, "a escola pública era para poucos" sendo boa para esses "poucos". Hoje, essa escola é para todos e especialmente, para os pobres e, como tal, deve ser de qualidade sociocultural. Isso significa "investir nas condiçóes que possibilitam essa nova qualidade que inclui transporte, saúde, alimentação, vestuário, cultura, esporte e lazer".

Com essa perspectiva, Gadotti (2003, p. 9) demanda o que seria uma nova qualidade, enfatizando:

Não basta matricular os pobres na escola (inclusão). É preciso matricular com eles, também, a sua cultura, os seus desejos, seus sonhos, a vontade de 'ser mais'. É preciso matricular o projeto de vida desses novos alunos numa perspectiva ética, estética e eco pedagógica. A educação integral precisa visar à qualidade sociocultural da educação, que é sinônimo de qualidade integral.

Em constante confronto com a teoria neoliberal, a concepção de escola para todos - incluindo seus aspectos sociais, e de qualidade sociocultural - traz consigo a orientação de que não é necessária somente a oferta de ensino para a sociedade, mas sim um investimento que estimule as áreas que precisam de atenção, o que significa que a instituição em si tem que abranger as pessoas como um todo. Porém, há uma inconformidade com o entorno e como ele é gerido. A partir da concepção que é trazida por Gadotti em sua fala, a proposta de uma Nova Qualidade compreende partir dos desejos de seus educandos, ministrando conhecimentos que queiram saber, propícios para suas vidas e muito significativos para seu aprendizado.

A qualidade em si entra como uma questáo avaliativa do que está sendo ofertado, comparando com o que se possui na realidade. A participação do neoliberalismo nessa demanda educativa permite a imposição de padróes em suas metodologias. $\mathrm{Na}$ educação social, a adjacência gira acerca do indivíduo, constituindo o seu ensino de maneira que ele se sinta deveras confortável e agente de açôes transformadoras, já que, aprimorando seu olhar crítico, pode expor seus pensamentos e suas análises, exprimindo quais e porque as mudanças podem 
ser feitas. Esse aspecto, controverso ao neoliberalismo, em que se encontram pessoas quietas e acomodadas com a situação cuja qualidade lhes impóe, faz com que permaneçam sem questionar os porquês de existirem essas padronizações; o costume da maioria é o de aceitar as regras, sem indagá-las, tendo-se nesse ciclo muito clara a objetivaçáo dessa proposta, que fornece um sentimento de bem estar, em um discurso de participação e qualidade estendida, conforme aponta Gentili (1995, p. 244):

O neoliberalismo ataca a escola pública a partir de uma série de estratégias privatizantes, mediante a aplicaçáo de uma política de descentralização autoritária e, ao mesmo tempo, mediante uma política de reforma cultural que pretende apagar do horizonte ideológico de nossas sociedades a possibilidade mesma de uma educaçáo democrática, pública e de qualidade para as maiorias.

Cabe ressaltar que, dentro de toda a lógica educativa, os pressupostos que guiam os indicadores de qualidade que buscam ser alcançados em quaisquer instituições de ensino, em parte, são orientados pelo Banco Mundial, importante "investidor", posicionando as demandas. Este delimita o que se deve alcançar e em qual período, com o fundamento de regularizar os gastos e apontar quais regiôes e áreas precisam de maior atenção. O Banco Mundial e o Fundo Monetário Internacional $(\mathrm{FMI})^{5}$ demandam à política pública educacional brasileira que descentralize a gestão educacional, otimizando recursos e, como estratégia de controle de qualidade, centralize a avaliação a fim de que seja constituído um sistema nacional, o qual todas as escolas devem submeter-se. Com base em Junior e Maués (2014, p. 1140):

A descentralização da gestáo em seus aspectos administrativos e financeiros significou a responsabilização crescente das instituiçóes escolares pelo rendimento escolar de seus alunos, a partir de parâmetros de avaliação definidos externamente e maior racionalização de nos gastos, incluindo incentivo à captaçấo de recursos via parcerias público-privadas e via projetos de voluntariado, como o Amigos da Escola. E a

5 Ao fim da $2^{\text {a }}$ Guerra Mundial os EUA saíram fortalecidos do conflito e criaram o Banco Internacional para Reconstruçáo e Desenvolvimento (BIRD), o Fundo Monetário Internacional (FMI) e outros Agentes para ampliar sua influência no mundo que se reestruturava. Deste lugar de controle é que estes organismos agem para um mundo "pró-neoliberal" e um conservadorismo fiscal. 
centralização dos sistemas de avaliação como forma de fixar padróes de desempenho e induzir aos resultados esperados pelas escolas e pelos alunos.

Estes sistemas de avaliação advindos de propostas governamentais trazem consigo a concepção de descentralização ocorrido nas instituições de ensino. Conforme Junior e Maués (1999, p. 1140) "É nesse contexto que são implantados o Sistema de Avaliação da Educação Básica (SAEB), de 1990, o Exame Nacional do Ensino Médio (ENEM), de 1998, e o Exame Nacional de Cursos (ENC), criado em 1995". Conforme Cury (1996), a LDBEN no 9394 Brasil (1996) reflete essa perspectiva de descentralização em termos da flexibilidade do planejamento e da gestão administrativa e financeira que 'são repassadas à escola e a forte centralizaçáo na avaliação, entendida como controle de resultados e fixação de padrôes de desempenho". Assim, o controle não estaria mais diretamente relacionado ao currículo e aos processos pedagógicos, mas sim na saída, mediante avaliação.

Nessa perspectiva, o Banco Mundial vê na educação, "um filão em possibilidades de parceria com setores privados, comercialização de recursos tecnológicos, etc." Conforme aponta o relatório do FMI, o intuito da padronização de conteúdos programáticos será a nova orientação ao Brasil, o que já ocorreu com a produção da Base Nacional Comum Curricular - BNCC. Nesse contexto, a qualidade da educação é a condição da eficiência econômica.

Em contraposição, Gadotti (2003) defende muito uma educação social e sustentável que traz à tona uma nova perspectiva de vida e, consequentemente, de qualidade. Para Gadotti (2003, p. 17), precisamos escolher uma "construção de maior valor social, a partir da sustentabilidade: pois introduzir uma cultura da sustentabilidade e da paz nas comunidades escolares é essencial para que elas sejam mais cooperativas e menos insolidárias. Necessitamos de outros paradigmas, fundados numa visão sustentável do planeta Terra (GADOTTI, 2003).

Em paralelo a estas posiçóes indiciadas e em defesa da educação sustentável ${ }^{6}$, há uma crítica que envolve o estilo de vida adquirido na atualidade que interessa

6 Assim, Sustentabilidade é uma ideia para definir ações e atividades humanas que visam suprir as necessidades atuais dos seres humanos, e não comprometer os recursos legados aos futuros, os herdeiros, as próximas geraçôes que habitarão o planeta Terra. Pensar na produção recorrente da "sociedade de consumo", que é exatamente o oposto do desenvolvimento sustentável, usar com inteligência os recursos que necessitamos passam a ser focos da Educação para a Sustentabilidade e Educação Social. Para além de constituir um direito humano fundamental, a educação é igualmente um pré-requisito para se atingir o desenvolvimento sustentável e um instrumento essencial à boa governança, às tomadas de decisão informadas e à promoção da democracia (O nosso futuro comum. Comissão mundial sobre o meio ambiente e o desenvolvimento. Organização das Naçóes Unidas, 1991). 
muito aos que vivem da lógica de mercado. Nesta, as pessoas têm desenvolvidas as capacidades de intervir, de terem um olhar mais amplo sob as perspectivas que regem as suas próprias realidades. Essa concepção relacionada à educação social opóe-se da abordagem neoliberal, em que os indivíduos estão atrelados a prognósticos e modelos de vida que envolvem o individualismo e o consumo, como exemplos.

\section{No Parecer $n^{\circ} 11 / 00$, percepções sobre qualidade na EJA}

Atribuindo uma harmonia a essa concepção deveras sustentável, trazida pelas concepçóes de Gadotti (2003), aborda-se como questáo normativa o Parecer $\mathrm{n}^{\circ}$ 11, Brasil (2000), que apresenta as Diretrizes Curriculares Nacionais da Educação de Jovens e Adultos, que compreende a EJA como modalidade com suas peculiaridades.

Embora o texto não negue a formação para o trabalho, colocando-a como necessidade, tendo em vista "os tempos de grandes mudanças e inovaçóes nos processos produtivos" (BRASIL, 2000) enuncia que o jovem e o adulto, através da EJA "pode retomar seu potencial, desenvolver suas habilidades e confirmar suas competências adquiridas na educação extraescolar e na própria vida" (BRASIL, 2000). Essa forma de olhar não nega a influência da lógica de mercado e dos processos neoliberais presentes na educação, mas os reconfigura na medida em que inverte essa lógica na perspectiva dos sujeitos. Assim, do ponto de vista deste parecer, a EJA deve ser pensada para o seu público, reforçando, de fato, o que uma modalidade é; constituindo-se num jeito, um modo diferenciado de ser, com base no seu público. A partir disso, o documento passa a afirmar que uma educação de qualidade influencia "como fator preponderante na qualidade de vida das pessoas" (BRASIL, 2000). O parecer deixa claro que as características da modalidade devem ser respeitadas e consideradas com a formação de um professor que seja um profissional na área, e que a reconheça como tal. Não bastam, apenas, demandas e números que mostrem o que vem acontecendo nas instituiçóes de ensino. É congruente que exista capacitação para os docentes atuarem e que este seja um fator relevante a esta qualidade esperada. Neste, a palavra "qualidade" aparece articulada ao direito à educação e atrelada às funçóes da própria EJA como benefício para os estudantes. Para que a contextualização destes pressupostos que regem a modalidade em questão, se apresentem de forma clara, o relator elenca as funçóes da EJA, que se constituem como reparadora, equalizadora e qualificadora, que proporcionam um olhar criterioso sobre a oferta desta educação, a fim de compreender a sua própria existência, enquanto modalidade EJA. 
Em princípio, após as lutas para fazer desta a modalidade de ensino que oferta oportunidade aos adultos que náo puderam, por múltiplos fatores, estudar em outros tempos, tem-se a função reparadora como intenção de regularizar uma situação histórica. Perante o olhar deste parecer, que alerta que reparação não é suprimento, a função reparadora "[...] Significa não só a entrada no circuito dos direitos civis pela restauração de um direito negado: o direito de uma escola de qualidade, mas também o reconhecimento daquela igualdade ontológica de todo e qualquer ser humano".

Assim, desta "negação, resulta uma perda: o acesso a um bem real, social e simbolicamente importante. Logo, não se deve confundir a noção de reparação com a de suprimento". Neste sentido, a função reparadora deve ser vista como uma oferta mais concreta da presença de jovens e adultos na escola, resgatando a conquista da cidadania antes perdida, e agora, com garantia de qualidade, bem como a inserção no mundo de trabalho, através de aquisição de competências necessárias e exigidas para tanto. Inserindo neste contexto tem-se a ideia de que a EJA toma a forma de integrar, qualificando mais a cidadania na sociedade.

A função equalizadora se exprime em ser uma alternativa viável, propondo que a EJA seja pensada e constituída por processos pedagógicos que satisfaçam as necessidades de aprendizagens, de seus estudantes. Sobre essa função, o texto manifesta que a reentrada no sistema educacional "deve ser saudada como uma reparação corretiva, ainda que tardia, possibilitando aos indivíduos novas inserções no mundo do trabalho, na vida social, nos espaços da estética e da abertura dos canais de participação".

Essas "novas inserçóes dos sujeitos" impõem mudanças e inovações na proposta a ser desenvolvida na EJA para que o estudante consiga retomar seu potencial, explorando suas habilidades e competências, participando, de forma construtiva com sua experiência de vida, a fim de qualificar-se ainda mais. Deste modo, chegase a função qualificadora, que chama a atenção no sentido de que os conhecimentos dos jovens e adultos se articulem aos universalmente construídos de forma adequada e mediante valores universais. A esse respeito, o documento diz: "Mais do que uma função, ela é o próprio sentido da EJA". Ela tem como base o caráter incompleto do ser humano cujo potencial de desenvolvimento e de adequação pode se atualizar em quadros escolares ou não escolares. Desta forma, "mais do que nunca, ela é um apelo para a educação permanente e a criação de uma sociedade educada para o universalismo, a solidariedade, a igualdade e a diversidade".

Esta função, tem como sinônimo a "função permanente", induzida pela relação com o conceito de qualidade. Embora, numa perspectiva de qualidade social, a funçáo qualificadora dialoga e cumpre a promessa de conquistar os conhecimentos requeridos pela sociedade que impóe, além da competição como 
ponto de sobrevivência. Isso significa que, onde existe desemprego ou avanço tecnológico, os jovens e adultos que desejam ocupar-se disso, devem, portanto, minimamente estarem capazes para assumir tais papéis. Ainda assim, é possível à modalidade EJA reificar que existe a possibilidade de, em qualquer época, obterse formação, melhor empregabilidade, desenvolver e aprimorar os já estabelecidos conhecimentos.

\section{A pesquisa}

Do ponto de vista metodológico, realizou-se pesquisa qualitativa em educação, efetivando-se, de acordo com os procedimentos, pesquisa bibliográfica e pesquisa de campo. Segundo Minayo (1994, p. 21), a pesquisa qualitativa: "trabalha com o universo de significados, motivos, aspiraçóes, crenças, valores e atitudes", cujas relaçóes, processos e fenômenos "não podem ser reduzidos à operacionalização de variáveis". Nessa perspectiva, a coleta de dados ocorreu mediante a realização de entrevistas semiestruturadas, que foram efetivadas e registradas em áudio, com a autorização dos participantes. As entrevistas foram transcritas na forma como foram relatadas. A identidade dos participantes foi preservada, conforme prerrogativas e termo de consentimento informado da universidade. Segundo Gil (2010, p. 50), o uso de questionários e entrevistas tem importante papel, pois estes instrumentos "caracterizam-se pela interrogação direta das pessoas, cujo comportamento se deseja conhecer, em papel ou pessoalmente, por questionamento direto".

Para tanto, na Escola que oferta Educação Básica de EJA, buscou-se, como sujeitos a serem entrevistados, primeiramente, um ex-coordenador da modalidade, por sua inserção e conhecimento na realidade da escola pública estadual e, também, ouviu-se um professor de EJA da mesma instituição. Na universidade buscouse, de igual forma, os coordenadores dos cursos de Licenciatura em Pedagogia e Administração Rural e Gestão Agroindustrial, que também atuam como docentes nessas graduaçóes. A escolha destes profissionais ocorreu por acumularem saberes de gestão, com a docência de graduação. Na perspectiva de ouvir as vozes dos estudantes, três egressas da Educação Básica de EJA foram entrevistadas. Entre elas, duas estudantes cursam Licenciatura em Pedagogia e uma, bacharelado em Administração Rural e Gestão Agroindustrial. A análise destas falas foi conduzida de acordo com a Análise de Conteúdo proposta por Bardin (2011, p. 38). Tratase de uma técnica de investigação que "através de descrição objetiva, sistemática e qualitativa do conteúdo manifesto das comunicaçóes tem por finalidade a interpretação das mesmas". 


\section{Sobre as vozes dos professores e estudantes}

Por intermédio das entrevistas realizadas com os professores e alunos, sejam eles da modalidade EJA ou do Ensino Superior, têm-se aspectos de suma importância para a compreensão do termo "qualidade" e quais seriam estes insumos táo almejados pela legislação.

O primeiro grupo de falas refere-se a manifestaçóes dos docentes da EJA. As entrevistadas, agora denominadas: Coordenadora - EJA e Professora - EJA, possuem 55 e 69 anos, ambas de sexo feminino e atuantes na mesma escola estadual que oferta modalidade EJA no turno da noite. No sentido de verificar como conceituam qualidade, as professoras da escola dizem que:

- Qualidade é um trabalho bem feito, é a oferta de subsidio para que tudo que tu 'vả propor tenha, da maneira mais ampla possivel, um objetivo maior e que dê resultados positivos, pois você pode fazer qualquer tipo de serviço e relaxar, ou seja, sem qualidade nenhuma, da mesma forma que pode fazer um serviço com qualidade, por isso deve-se haver capacitação. (Coordenadora-EJA)

- Qualidade é tudo de importante, pois, se a possuimos, temos a certeza de ir bem no mercado de trabalho e até na educação. Comparo ela à expressão '8 ou 80': temos ela para que seja algo bom, ou não temos e o resultado será ruim. (Professora - EJA)

As duas entrevistadas atendem ao solicitado e apresentam os seus conceitos de qualidade. Esses conceitos representam concepçóes adquiridas histórica e socialmente, mesmo que inconscientemente. Essas abordagens incorporam expressóes que as identificam, bem próximas de uma concepção neoliberal de qualidade. Entre elas destacam-se "a oferta de subsídio", "objetivo" “o resultado". Esse resultado, presente no discurso de ambas é valorado como "positivo", "bom" ou "ruim". De uma forma direta, na fala da professora de EJA "a qualidade é tudo de importante" relacionada à "certeza de ir bem no mercado de trabalho e até na educação". Ao que parece, essas vozes que falam no dizer da professora valorizam mais a qualidade para a inserção no mercado de trabalho em si, do que para a educaçáo, que fica em segundo plano. Essa qualidade tem valor de exatidáo, conteúdo numérico como o expresso em "8 ou 80 ". Interessante que esta voz da qualidade em seu sentido técnico - instrumental como especifica Marques (2000) - apaga no dizer das professoras qualquer relaçáo de conhecimento ou experiência, táo reproduzidos em discursos educacionais ou de EJA. 
Nessa mesma direção, buscou-se saber o conceito de qualidade para as professoras do ensino superior público.

-Qualidade é possuir uma boa infraestrutura em termos de universidade, um horário para que os professores tenham preparação para as aulas, terem como se aperfeiçoar, não ter uma carga horária tão excessiva, possuir uma sede própria, acesso à rede de internet e recursos, biblioteca adequada, formação dos professores, etc. (Coordenadoralprofessora Pedagogia)

-Qualidade me lembra algumas palavras, tem a ver com melhorias, talvez uma evolução durante o tempo, o que daria para contrapor com quantidade e números, no sentido de melhorias, indicadores, 'melhorar'... (Coordenadoralprofessora - Administração Rural e Agroindustrial)

A primeira entrevistada, ao responder à questão, apresenta respostas a partir da realidade em que vive na universidade, ou seja, fala no que não tem ou não ocorre a contento. Os itens apresentados pela mesma são os almejados pelos indicadores de qualidade preconizados para a educação, desde a LDB (BRASIL, 1996).

A fala da segunda entrevistada, de forma direta, apresenta e lembra termos que também são referidos pela legislação educacional geral conforme padróes. Estes constituem indicadores que podem expressar "melhorias" e "evoluçâo" "durante o tempo". Mais uma vez, o conteúdo presente nas vozes das professoras está relacionado às concepçóes neoliberais de qualidade. Em relação ao significado da qualidade na demanda específica da educação, a Coordenadora da EJA respondeu:

- Tu 'oferece' qualidade na educação quando sabe o que está fazendo, e tu só 'sabe' o que tu faz se tu 'correr' atrás de atualizaçóes, de pesquisas, de estudo, tá sempre, o tempo todo buscando, sempre inovando, propostas, pensadores, outras formas de trabalhar, estratégias, metodologias, ou seja, qualidade na educą̧ão é a busca de conhecimento para que tu sempre 'atualize' tuas propostas pedagógicas na realidade a qual esteja sendo inserida. (Coordenadora - EJA)

O conteúdo presente na fala dessa professora lembra as palavras de Gentili (1999, p. 47) que por conta da estatização malsucedida há "um sistema escolar rígido e incapaz", de garantir "a eficácia e a eficiência dos serviços oferecidos". Por conta disso, produz-se a competição interna e o desenvolvimento de um sistema de prêmios e castigos com base no mérito e no esforço individual dos atores envolvidos 
na atividade educacional. Imbuída por essa concepção, a professora, sem refletir sobre o que diz, remete a si o que a política de estado e gestão educacional em suas esferas deveriam se ocupar. A formaçáo de professores, conforme o que aponta a atual LDB e o Parecer 11/2000, é dever de política de estado.

A segunda entrevistada sobre a qualidade na educação, diz:

-Eu acho até que a gente tem muita qualidade na educação, só que 'tá' difícil a educą̧ão em si, porque talvez o próprio governo não dá exemplo, e porque as famílias estejam cada vez mais trabalhando fora, os filhos ficam por conta, outras já não estão nem aí com o que acontece com seus filhos, e eles vêm muito carentes de casa, entrando na conversa do colega, não prestando atenção e a educação fica a desejar. A gente se esforça e até os pressiona para que eles participem, porém é bem complicado. Ou seja, a qualidade na educação é uma aula bem preparada, com propostas que os alunos se interessem, que sejam motivados em casa, em questâo dos horários, disciplina, tenham materiais básicos, enfim, tudo. (Professora - EJA)

A fala realizada pela professora envolve o que falta e dificuldades enfrentadas pelos professores, fazendo críticas ao governo, às famílias e aos alunos. O governo não cumpre seu dever, então, as famílias "cada vez mais" têm que trabalhar "fora" e "os filhos ficam por conta". Isso gera, de forma cíclica, uma série de consequências, como denuncia a professora. Para que haja qualidade na educaçáo, pensando a "aula", as "propostas" que considerem "os interesses" tem que haver organização e motivação "em casa", "horários, "disciplina”, "materiais básicos", "enfim, tudo" o que não se tem. Ela reforça "a gente se esforça, porém, é bem complicado".

Para a professora qualidade é "tudo". Em sua fala, demanda por qualidade sociocultural, como apresenta Gadotti (2003). Do questionamento sobre qualidade na educação, assim se manifestaram as professoras:

-A qualidade na educação passa pela formação dos professores, que talvez não seja correta para o curso em questão, tampouco para comportar alunos com necessidades especiais. (Coordenadoralprofessora - Administração Rural e Agroindustrial)

-A qualidade pra mim tem a ver com indicadores. Talvez a qualidade na educaşão possa ser medida, analisada, através de alguns indicadores. Qualidade na educação, eu acho que, tem a ver com muitos (ressalta na fala) fatores, por exemplo: professores com uma boa formação, capacitaçẫo, uma boa infraestrutura, incentivo 
ao aluno em termos de buscar a informação, conhecimento, dentro dos seus estudos, são fatores que devem ser levados em consideração pra que se tenha uma evolução, uma qualidade dentro da educação. (Coordenadora/professora - Pedagogia)

As duas responderam no sentido de aprimorar o ensino que já existe e ambas ressaltam a qualidade relacionada à formação de professores. A fala da primeira corresponde ao que falta, questionando a qualidade da formação oferecida pelo próprio curso que, segundo ela, "talvez não seja correta". A segunda, apresenta "fatores" no sentido de "fixar padrôes de desempenho e indução de resultados", como falam Junior e Maués (2014).

$\mathrm{Na}$ tentativa de levantar quais seriam os parâmetros que regeriam um ensino mais satisfatório, em comparação com o que se possui atualmente, a professora da escola falou:

- Pra 'ti' oferecer qualidade na EJA, tem que se trabalhar motivação, pois o público de EJA, em sua maioria, são pessoas que estão vindo do seu trabalho, cansadas, muitas vezes sem jantar ou conseguir tomar um banho, ai se não se oferece um trabalho de qualidade em sala de aula, como você espera que ele retorne no outro dia, ou mesmo, que fique até o fim da aula? Outra coisa que é fundamental para qualificar o ensino da EJA, é a não infantilização dos alunos, deve-se trabalhar com um assunto que eles realmente queiram aprender, que vá render pra eles. (Coordenadora - EJA)

Ao referir sobre parâmetros de qualidade a professora elenca o que falta, apresenta problemas e dificuldades. Caracteriza o público da EJA e o que essa demanda. Qualidade aprece articulada a não infantilização, a aprendizagem significativa e desejos, a manutenção, frequência e permanência dos estudantes. Como contraponto da realidade desta escola, a professora entrevistada traz fatores diferenciados, elencando aspectos positivos da qualidade na EJA:

-A qualidade na EJA, acho muito boa, a iniciar pelos livros deles, se quiserem ou interessarem em ler, adquirem um conhecimento muito amplo, já que o contenido que passamos tem de ser de forma bem sucinta, por isso este esclarece bastante as coisas. Percebo uma grande evolução dos alunos a partir das aulas. Eu trabalho de maneira clara, com linguagem compreensiva, não me distancio deles, fico próxima, sociável com eles, pra que possuam abertura pra questionamentos, para aqueles que têm interesse, se torna valioso. (Professora - EJA) 
A professora afirma, ainda, que a qualidade na EJA é muito boa e justifica sua afirmação apresentando fatores que potencializam essa qualidade como livros, conduta de proximidade com os alunos, trabalho de maneira clara, linguagem compreensiva, proximidade, sociabilidade, abertura para questionamentos e interesse.

Em perspectiva semelhante, as Coordenadoras de Cursos da universidade também apresentam fatores de qualidade, conforme as falas que seguem:

-Eu acho que uma das questóes da qualidade que nós temos é um quadro de professores qualificados, a maioria já doutores $e$ os demais se formando em doutores e pós-doutores. Já a qualidade na minha prática, é tentar trazer novas abordagens, estimular que o aluno seja crítico e participe das aulas com as suas construçôes. Com o advento do WhatsApp criamos um link entre aluno e professor que antes não existia, e isso facilita bastante em termos de organização, esclarecimentos, etc. (Coordenadora/professora - Pedagogia).

- Nós enquanto docentes, se reconhecer, tendo que buscar novas metodologias, novos espaços, para que possamos passar o conteúdo de forma diferente, chamando mais atenção do aluno, e que esses pontos, possam se tornar a qualidade na educação ministrada. Como ponto de discussão durante este ano, tem-se o agravante de infraestrutura, que, com o advento da universidade ser pequena, necessita-se buscar algo melhor, pois já estamos crescendo bastante e isso facilita na permanência $e$ no interesse acerca das aulas. (Coordenadora/professora Administração Rural e Agroindustrial).

As coordenadoras apresentam fatores ou aspectos de qualidade que reconhecem nos cursos que coordenam. Entre os fatores têm destaque: quadro de docentes, novas abordagens na prática, estimular a criticidade e participação nas aulas, uso de WhatsApp na comunicação, reconhecimento, busca por novas metodologias, infraestrutura, permanência e interesse dos alunos.

\section{Acadêmicas egressas da EJA}

As acadêmicas, estudantes egressas da EJA são todas adultas, as três estão em fases finais dos seus cursos, tendo idades entre 26, 41 e 53 anos. Demostram-se felizes por estarem na universidade, empenhando-se para participar da entrevista. Trazem consigo a emoção de saberem buscar, sozinhas, as informaçóes solicitadas pelos professores, e de terem, ao longo do período na universidade, conseguido 
dominar as tecnologias disponíveis para o que precisarem. Ressaltam a grande importância de práticas realizadas fora da sala de aula. Projetam, com a conclusáo dos seus cursos, o aprimoramento de seus conhecimentos, e o proveniente trabalho na área desejada.

As estudantes possuem diferentes argumentos quando se trata das dificuldades que tiveram ou ainda estão enfrentando em seus cursos no Ensino Superior. As variaçóes se perfazem em: "dificuldades nas disciplinas à distância e vespertino, em que as explicaçóes não ficam completas como deveriam; dificuldades para interpretar a ordem dada pelo professor, havendo necessidade de pesquisa na internet para que a intenção fique esclarecida; dificuldades em matemática, por pensar que não conseguiria acompanhar, deixando para os últimos semestres". As mesmas tentam superar tais dificuldades pedindo ajuda para os colegas, ou ainda, como citado na fala de uma das estudantes, "em buscas na internet". Alegam possuir bastante contato com seus professores, porém, ainda não há abertura suficiente para que suas dificuldades sejam resolvidas por alternativa da universidade, como parte do currículo.

Como constatado, das três acadêmicas entrevistadas, todas possuem alguma dificuldade que não fora sustada por nenhum dos professores. Isso se deve ao fato de que os mesmos não possuem conhecimento sobre a realidade de egressos da EJA na instituição. As professoras/coordenadoras entrevistadas reagiram com surpresa ao compreenderem estes casos e, ainda, afirmam que esses alunos realmente possuem mais dificuldades em relação aos demais, porém, recebem tratamento igualitário, e se propóem, de forma aberta, "a auxiliar" em quaisquer dúvidas que possam surgir.

Refletindo sobre possíveis faltas em seus cursos, as acadêmicas assim se posicionaram:

-Não, acho que falta algumas coisas. Por exemplo, temos pouca aula de disciplinas importantes, principalmente quando nos é ofertado vespertino. Existem aulas que a gente não consegue acompanhar e as coisas ficam meio a desejar. E em termos de cursos à distância, a gente fica sem apoio 'pras' dúvidas. (Acadêmica Pedagogia 1)

- Acho que sim, porque tiramos muito proveito. Quem fez EJA sabe o que se passa de dificuldade, e 'teve' momentos que eu pensei que não ia dar conta por causa da falta de um ensino médio regular, por isso o conhecimento obtido na universidade foi muito proveitoso. (Acadêmica Pedagogia 2)

- Acho que é bom, sim, pois é bem amplo, me completa o que faltou na EJA, por exemplo, história é algo que eu 
'tô' buscando para conseguir compreender bem, visto que vimos as disciplinas de forma rápida demais. (Acadêmica Administração Rural e Agroindustrial)

Diante dessas respostas, encontram-se críticas em torno dos cursos que as alunas desempenham. O conjunto completo das alunas entrevistadas está em fase final de curso na universidade e atribuem papéis positivos e negativos às aulas que receberam ao longo do tempo. Afirmam, ainda, possuírem algum tipo de dificuldade e que, para saná-las, contaram com o auxílio de professores e colegas de forma a compreender melhor os temas até então novos, estes pouco abordados na sala da EJA.

Tendo por base a perspectiva de mudar algo em seus cursos, o que possibilitaria deixar a sua permanência mais "aproveitável" e adequada para sua formação, as alunas fazem as seguintes proposiçóes:

- O curso deveria ter mais práticas nas turmas, ou seja, permitir que a gente possa ter mais oportunidades de atuar em sala de aula. (Acadêmica Pedagogia 1)

- Eu não vejo uma necessidade de mudar a Pedagogia, mas sim, me debruçar mais sobre as disciplinas que não compreendo; (Acadêmica Pedagogia 2)

- Não mudaria nada na Administraçäo Rural, pois acho um curso bem completo, que preenche o que não tive na EJA. (Acadêmica Administração Rural e Agroindustrial)

Conforme as colocaçóes, as entrevistadas demonstram gostar dos cursos escolhidos. Uma delas pede por "mais práticas no seu campo de atuação", que seria a sala de aula, fora dos estágios supervisionados que o curso oferta. As demais compreendem que o esforço para que as aulas sejam melhores para si é um esforço advindo delas mesmas, visto que sua formação de EJA - Ensino Médio, não forneceu subsídios suficientes para o pleno conhecimento que gostariam de agregar. A universidade também tem sido um complemento para o aprendizado, esforçando-se, da maneira possível. Apesar de apresentarem argumentaçóes sobre seu estado atual, demonstrando fragilidades, consideram alguém egresso de EJA, ter a oportunidade de ser estudante de um curso superior público e gratuito, como algo muito importante e imensurável.

A fim de compreender as relaçóes que esta realidade assegura, as estudantes compartilham seus sentimentos:

-Me sinto outra pessoa. Antes eu não sabia falar, me socializar. Eu cresci bastante em termos de me impor. Percebi que ser acomodada náo resolve e, com a faculdade, 
aprendi a não desistir facilmente dos objetivos. (Acadêmica Pedagogia 1)

Estudante 2 - Me sinto valorizada. Tudo que eu começava, desistia, pois pensava que não era pra mim, que não valia a pena, porém Pedagogia é uma área que eu gosto, algo que me interessa e, por isso, não desisti. (Acadêmica Pedagogia 2)

Estudante 3 - Me sinto muito feliz. Nunca pensei que eu fosse capaz de estar numa universidade, portanto, dou valor à minha estadia aqui e me esforço bastante pra fazer destas aprendizagens, algo válido para a minha vida. (Acadêmica Administração Rural e Agroindustrial)

Com base nestes dizeres, nota-se que, por mais que haja dificuldades em seus caminhos, as três acadêmicas anunciam estarem obtendo "bons aproveitamentos" nos cursos em que estão matriculadas e frequentam. É importante relatar que, apesar de considerarem o "advento de provirem da Educação de Jovens e Adultos", relatam, hoje, que esse foi um ensino que pode ser considerado "fraco", "não abrangente dos conhecimentos necessários para se prestar um vestibular"; elas transpassam felicidade e realização ao encontrarem na universidade o que lhes faltavam. As discentes complementam, ainda, que, para seu total aproveitamento acerca das disciplinas ministradas na universidade em questão, seria interessante "dedicar-se mais, fazendo bastante leitura para tirar dúvidas das teorias"; "escolher uma faixa etária para aprofundamento de materiais e estudos a fim de trabalhar com a mesma" e, ainda, salientam a necessidade de "agrupar mais a administração de empresas não somente rural, pois, assim, teríamos uma oportunidade maior de ingressar direto no mercado de trabalho". Novamente, elencando as conotaçôes neoliberais de estudo para melhoria na qualidade, a partir do trabalho, as estudantes procuram desempenhar seus papéis com a finalidade de, assim que obterem as formaçóes, iniciarem as atividades com base nos conteúdos estudados, aplicando suas aprendizagens e progredindo mais. A apresentação e análises descriminadas revelam que os discursos sobre qualidade são múltiplos.

Nos dizeres dos professores aparecem concepçóes de qualidade, em grande parte das vezes, como senso comum instituído de perspectiva neoliberal. $\mathrm{Na}$ fala das acadêmicas egressas de EJA, por outro lado, as perspectivas de qualidade social se fazem presentes em grande maioria. Ou seja, elencam os pressupostos conotados por Gadotti (2003) e Gentili (1999) os quais transparecem as concepçóes que se contrapóem em sentido de exemplificar o dinamismo que procede e educação atual. Em boa parte dos enunciados 
dos professores, em abordagem sobre qualidade, se sobressaem os problemas e os que lhes falta. Entre esses problemas, o de infraestrutura é bem geral e, no que tange a EJA, a infantilização aparece de forma específica.

Dentro de ambos os casos, são quesitos propostos como inferências do que se deve fazer ou suprir, a fim de que a modalidade obtenha sua própria identidade, em consonância com as práticas que contribuem para estas melhorias. De um modo amplo, embora esse náo fosse o foco do trabalho, junto às vozes sobre a qualidade, foram apontados indicadores de qualidade, conforme apresenta o quadro que segue, especificando de modo sucinto, quais são estes ideais:

\section{Quadro - Sentidos de qualidade}

\begin{tabular}{|c|l|l|}
\hline \multicolumn{1}{|c|}{ Perspectivas } & \multicolumn{1}{|c|}{ Concepções de Qualidade } & \multicolumn{1}{c|}{ Qualidade como Indicadores } \\
\hline \multirow{5}{*}{ Perspectivas EB- EJA } & $\begin{array}{l}\text { Aprimoramento da metodologia; } \\
\text { Resultados positivos; } \\
\text { Preparo para o trabalho; } \\
\text { Trabalho bem feito; } \\
\text { Consciência do que se faz. }\end{array}$ & $\begin{array}{l}\text { Incentivo à permanência; } \\
\text { Não infantilização; } \\
\text { Insumos básicos para que o aluno } \\
\text { não evada; } \\
\text { Aprendizagem } \\
\text { Qualificação das práticas. }\end{array}$ \\
\hline Perspectivas Ensino Superior & $\begin{array}{l}\text { Indicadores para melhoria do ensino; } \\
\text { Infraestrutura adequada; } \\
\text { Formação para o docente. }\end{array}$ & $\begin{array}{l}\text { Acessibilidade; } \\
\text { Formação do professor; } \\
\text { Metodologias novas; } \\
\text { Infraestrutura; } \\
\text { Laboratório de estudos e biblioteca. }\end{array}$ \\
\hline Perspectivas das discentes & $\begin{array}{l}\text { Inserção no mercado de trabalho; } \\
\text { Resgate da aprendizagem não } \\
\text { desenvolvida; } \\
\text { Sentimento de felicidade com o que } \\
\text { faz ou estuda. }\end{array}$ & $\begin{array}{l}\text { Aprimoramento do conhecimento; } \\
\text { Práticas participativas; } \\
\text { Oferta de atividades diferenciadas; } \\
\text { Superação das dificuldades não } \\
\text { abordadas antes. }\end{array}$ \\
\hline
\end{tabular}

O que esse quadro revela é o quanto é importante perguntar e ouvir as pessoas. As abordagens de qualidade social, que se sobressaem em boa parte dos indicadores presentes nos dizeres das discentes, revelam essa importância. Ao que se evidencia, as acadêmicas oriundas da EJA se percebem participando, superando dificuldades e aprimorando conhecimentos, nesse contexto. 


\section{Reflexões finais}

O presente artigo constitui sua importância por conceituar e refletir sobre a qualidade de forma a apresentar seus meandros, significados, e, também, na perspectiva de como os discursos sobre qualidade que veiculam nas escolas de Educação Básica da Modalidade de Educação de Jovens e Adultos e na Universidade, através dos dizeres, em circulação, de professores e estudantes egressos da EJA.

O que se evidencia é que, nas vozes dos participantes da pesquisa, circulam discursos da qualidade diversos, mas, nos dizeres dos professores a vinculaçáo maior relaciona-se às concepçóes neoliberais bem mais que os relacionados à qualidade social, presente de forma mais ampla nos dizeres das acadêmicas egressas da EJA. Importante destacar que, nas vozes dos professores, abranger o tema da qualidade, de forma geral implica em falar no que sempre falta e a destacar problemas.

Conforme já referido, essa pesquisa não teve a intenção de abordagem nos indicadores de qualidade e táo pouco em seu entendimento como ferramenta de gestão, mas ao final, por conta de ocorrências dos conteúdos nas falas, uso de expressóes e palavras sistematizaram-se os indicadores, como efeito da entrevista estabelecida.

O que o presente artigo apresenta ao mundo acadêmico é que, embora essas instituiçóes sigam padróes e indicadores de qualidade externos que têm em si concepçóes neoliberais, talvez pudessem e devessem ouvir a sua comunidade escolar ou universitária para que, assim, quem sabe, as vozes da qualidade social pudessem ecoar, com maior intensidade.

\section{Referências}

BARDIN, L. Análise de conteúdo. São Paulo: Edições 70, 2011.

BRASIL. Constituição (1988). Constituição da República Federativa do Brasil. Brasília, DF: Senado Federal: Centro Gráfico, 1988.

. LDB. Lei de Diretrizes e Bases da Educaçáo Nacional: no 9394/96. Brasília, DF: Senado Federal, 1996.

. Parecer 11/2000. Diretrizes Curriculares Nacionais para a Educaçáo

de Jovens e Adultos. Disponível em: shttp://www.portal.mec.gov.br/cne/ arquivos/pdf/PCB11_2000.pdf>. Acesso em: 11 abr. 2017. 
CARREIRA, D. (Org.). O uso dos indicadores da qualidade na educaçáo na construçáo e revisáo participativas de planos de educaçáo. 1. ed. São Paulo: Ação Educativa, 2013.

FERREIRA, Aurélio Buarque de Holanda. Novo Aurélio Século XXI: o dicionário da língua portuguesa. Rio de Janeiro: Nova Fronteira, 1999.

GADOTTI, Moacir. Qualidade na educação: uma nova abordagem. São Paulo: Instituto Paulo Freire, 2003.

GARVIN, D. A. Gerenciando a qualidade: a visão estratégica e competitiva. Rio de Janeiro: Qualitymark, 2002.

GENTILI, P. Escola S. A.: Quem ganha e quem perde no mercado educacional do neoliberalismo. São Paulo: CNTE, 1999.

. Pedagogia da Exclusáo: Crítica ao neoliberalismo em educaçáo. 9. ed. Rio de Janeiro: Vozes, 1995.

GIL, A. C. Como Elaborar Projetos de Pesquisa. São Paulo: Atlas S. A., 2010.

JUNIOR, W. P. da M.; MAUÉS, O. C. O Banco Mundial e as Políticas Educacionais Brasileiras. Porto Alegre: Educaçáo \& Realidade, v. 39, n. 4, p. 1137-1152, out./dez. 2014.

MARQUES, Ramiro. Dicionário breve de Pedagogia. 2. ed. [S.I.], 2000. Disponível em: $<$ http//www.eses.pt/usr/ramiro/docs/ética_pedagogia/ dicionário\%20pedagogia.pdf> Acesso em: 15 mar. 2017.

MINAYO, M. C. de S. (Org.). Pesquisa Social: Teoria, método e criatividade. 18. ed. Petrópolis: Vozes, 2001. 



\section{Educação e Psicologia}





\title{
A presença dos jogos de papéis na Educação Infantil
}

\section{The presence of role games in Early Childhood Education}

\author{
Maria Lidia Sica SZYMANSKI ${ }^{1}$ \\ Lisiane Gruhn COLUSSI²
}

\begin{abstract}
Resumo
Investiga-se se os jogos protagonizados ocorrem na Educação Infantil, pesquisando-se o Estado do Conhecimento, e apresenta-se um Estudo de Caso, referente a uma escola municipal, organizado em duas etapas: uma documental, envolvendo a análise do Projeto Pedagógico, e a outra envolvendo observação e anotaçôes em caderno de campo das atividades lúdicas de crianças de 5 a 6 anos, durante 14 horas. Constatou-se que a Educação Infantil não resolveu o falso dilema entre escolarizar e brincar, e não propicia tempo e espaço para jogos protagonizados. Conclusivamente, ressalta-se a importância de que a escola possibilite tais jogos, os quais são fundamentais para o desenvolvimento afetivo, social e cognitivo.
\end{abstract}

Palavras-chave: Educação Infantil. Jogos protagonizados. Psicologia Histórico-Cultural.
Abstract

We investigate whether role playing games occur in the kindergarten by researching the Knowledge State, and we present a Case Study concerning a Municipal School, involving two steps: one is documental, analyzing its Pedagogical Plan, and another, involving observation, which was registered in a field notebook, about role playing activities from children aged 5 to 6 years, during 14 hours. It was found that early childhood education no longer solved the false dilemma between schooling and playing, and did not provide time and space for role playing games. It was concluded, emphasizing the importance that the school allows the occurrence of such games, which are fundamental to emotional, social and cognitive development.

Keywords: Childhood Education. Role playing games. Historical-CulturalPsychology.

1 Doutora em Psicologia (USP). Docente do Mestrado em Educaçáo (UNIOESTE). Líder do GPAAD Grupo de Pesquisa Aprendizagem e Ação Docente.UNIOESTE - Campus Cascavel - PR.

2 Mestre em Educação (UNIOESTE). Membro do GPAAD - Grupo de Pesquisa Aprendizagem e Açáo Docente. UNIOESTE, Cascavel, PR. E-mail: <lisianegcolussi@gmail.com>.

\begin{tabular}{|l|l|l|l|l|l|} 
R. Educ. Públ. & Cuiabá & v. 28 & n. 67 & p. $41-61$ & jan./abr. 2019 \\
\hline
\end{tabular}




\section{Introdução}

A Psicologia Histórico-Cultural, ao estudar o papel da Atividade no desenvolvimento psíquico, ressalta a importância dos jogos de papéis ${ }^{3}$, na faixa etária dos 3 a 6 anos. Várias pesquisas, voltadas à Educação Infantil, têm discutido a questão lúdica no cotidiano pedagógico,entretanto, poucas se voltam especificamente aos jogos protagonizados. Assim, o presente artigo objetiva discutir se esses jogos ocorrem no cotidiano pedagógico, e de que forma eles se manifestam.

Para compreender essa questáo, inicia-se apresentando os principais conceitos que envolvem a discussáo sobre o desenvolvimento do psiquismo humano na perspectiva da Psicologia Histórico-Cultural, ressaltando a relação entre a atividade humana e a formação da consciência. A seguir, volta-se essa análise para o desenvolvimento do psiquismo infantil, ressaltando o papel do jogo protagonizado, atividade principal nesse processo, na faixa etária ora abordada. E reflete-se sobre a importância e o compromisso das escolas que promovem Educação Infantil, como responsáveis por desenvolver atividades mediadoras que promovam esse desenvolvimento.

Com o objetivo de situar as pesquisas nessa área, retoma-se a produção acadêmica acervada na Biblioteca Digital Brasileira de Teses e Dissertaçóes entre os anos de 2004 e 2014, referentes à periodização do desenvolvimento psíquico na faixa etária dos 3 aos 6 anos, voltadas ao estudo de Daniil Borisovich Elkonin (1904-1984), utilizando-se como busca as palavraschaves "Elkonin" e "jogos protagonizados".

A seguir, direciona-se essa análise a uma escola municipal, buscando os jogos protagonizados em sua proposta pedagógica e no cotidiano escolar de crianças de 5 a 6 anos. Finaliza-se ressaltando a importância de um processo de formação docente, que possibilite à escola compreender a relevância dos jogos protagonizados para o desenvolvimento emocional, social e cognitivo da criança, de forma a ofertar tempo e espaço, bem como disponibilizar materiais para que esses jogos de papéis possam ocorrer.

3 Este trabalho fundamenta-se no conceito de jogo proposto por Vigotski (2008), e posteriormente de jogos protagonizados/jogos de papéis, proposto pela escola soviética (ELKONIN, 2009). Assim, entende-se "jogo de papéis" e "jogos protagonizados" como sinônimos. 


\section{O desenvolvimento do psiquismo humano na perspectiva da Psicologia Histórico-Cultural}

O trabalho social, modificando as condições de existência, propiciou ao homem o surgimento da consciência, presidido pelas leis do desenvolvimento sócio-histórico, em detrimento das leis da evolução biológica (LEONTIEV, 1978). Nessa direção, a consciência

[...] é a expressão ideal do psiquismo, desenvolvendo-se graças à complexificação evolutiva do sistema nervoso central pela decisiva influência do trabalho e da linguagem, inaugurando a transformação do ser orgânico em ser social. Com o advento da consciência, a realidade - e tudo o que a constitui - adquire outra forma de existência representada pela imagem psíquica, pela ideia que dela se constrói. (MARTINS, 2013, p. 28).

Portanto, a dimensão qualitativa do desenvolvimento humano, na perspectiva filogenética, deve-se à superação da adaptação natural do homem ao meio, na medida em que estabelece coletivamente uma relação de troca com a natureza por meio das atividades que constituem o trabalho social, produzindo e modificando suas condiçóes biológicas iniciais ou originais.

Da mesma forma, na perspectiva ontogenética, as condiçóes de existência determinam as atividades da vida material, principalmente laborativas, e geram mudanças no comportamento e na consciência das pessoas. Conforme os estágios de desenvolvimento se sucedem, formam-se novas necessidades específicas no campo psíquico, envolvendo novas atividades. Odesenvolvimento dessas atividades é condição para as mudanças mais relevantes nos processos psíquicos e nas singularidades psicológicas da personalidade. Esse processo é permeado pela historicidade, pois cada cultura envolve diferentes atividades, as quais terão papel mediador nos processos de apropriação e objetivação que constituem o funcionamento psicológico.

No conjunto de atividades, aquela que predomina e envolve o modo/ meio pelo qual o sujeito estabelece suas principais relaçóes com a realidade externa, buscando satisfazer suas necessidades, é denominada atividade principal, que é provocada por um motivo e envolve açóes e operaçóes. Portanto, considera-se que o desenvolvimento da natureza social-humana se alicerça no trabalho, principal atividade por meio da qual o ser humano relaciona-se com o mundo. 
Com o desenvolvimento histórico, cultural e tecnológico humano, as necessidades biológicas, ainda que vitais, quando garantidas, tornam-se secundárias, e o homem privilegia as complexas necessidades sociais. São essas necessidades sociais que motivam a atividade humana e propiciam o surgimento da consciência. Elas estão originalmente submetidas a relaçóes sociais e condicionam a gênese da imagem psíquica, possibilitando às estruturas neuronais tornarem-se cada vez mais complexas (LEONTIEV, 1978; LURIA, 1991).

Nesse processo, a partir do entrecruzamento orgânico e cultural, desenvolvemse as funções psíquicas superiores (FPS), envolvendo ações conscientes e controladas, como o pensamento abstrato, raciocínio, atenção voluntária, percepção, sentimentos, memória mediada, linguagem e vontade, dentre outras. Trata-se de um processo constante, consequência da participação do sujeito em atividades compartilhadas. Antes de se constituírem como psicológicas, essas funçóes tipicamente humanas perpassam pelas relações entre as pessoas, em um processo interpessoal que se transforma em intrapessoal.

Destaca-se, portanto, que a consciência não resulta unicamente do mundo subjetivo, nem tampouco é resultado de um processo unicamente biológico, uma vez que ela se forma nas relaçóes do sujeito com o mundo à sua volta. Trata-se de um movimento dialético, no qual, ao mesmo tempo em que a consciência vai se ampliando, isso é, ao se ampliar a representação interna do mundo externo, apropriação que depende da atividade do sujeito, essa consciência regula a forma como o sujeito realiza a própria atividade.

A apropriação do mundo objetivo pelo homem por meio da atividade não é mera cópia, mas produto da reelaboração das suas apreensóes pessoais. Quanto mais esse processo de apropriação amplia-se, maior facilidade para novas apropriaçóes.

Em síntese, para a Psicologia Histórico-Cultural, no estudo do psiquismo, a consciência e a atividade são categorias centrais e entre elas há uma relação recíproca. A forma como o sujeito relaciona-se com a realidade, isso é, como ele funciona, envolve os processos funcionais tipicamente humanos, tais como atenção, percepção, memória ou pensamento. Desenvolver-se psiquicamente significa, principalmente, desenvolver essas funçôes, o que ocorre por meio das atividades, dentre as quais uma se destaca como mais importante em cada época do desenvolvimento. Portanto, o estudo do desenvolvimento psicológico acontece pela identificação e análise dessa atividade principal, e de sua relação com a consciência, isso é, com as açóes e operaçóes por ela mobilizadas, que compóem dialeticamente o processo integral do psiquismo.

Com base nesses pressupostos, na próxima seção, discute-se mais especificamente o desenvolvimento do psiquismo da criança. 


\section{O desenvolvimento do psiquismo infantil e o jogo protagonizado}

$\mathrm{Na}$ verdade, os fenômenos objetivos já estáo dados no contexto social, antecipadamente à consciência, porém cabe a ela captá-los e reconstituí-los. Desse modo, o desenvolvimento psicológico inicia-se à medida que a criança se apodera dos modos de fazer e dizer, construídos coletivamente pela humanidade. Não se trata apenas de um processo biológico de crescimento, mas de uma evoluçấo, na qual novas reorganizaçóes integram a dimensão cultural à biológica, ainda que um aspecto náo possa ser reduzido ao outro.

Conforme vai se tornando membro da sociedade, a criança passa a ter obrigaçóes por ela impostas e os estágios sucessivos do seu desenvolvimento são de fato graus diferentes dessa transformação. Processos anteriores preparam processos posteriores, em uma relação dialética de transformação e mudança, náo linear, guiada principalmente pela atividade principal, por isso também denominada atividade-guia. Entretanto, nem sempre a atividade-guia é a mais frequente; assim, para identificá-la, Leontiev propóe três aspectos:

Primeiramente é a atividade dentro da qual [surgem e] se diferenciam outros tipos de atividades. [...] [Por exemplo,] a criança começa a estudar, brincando. Em segundo lugar, na atividade-guia [...] se formam ou se reestruturam processos psíquicos particulares. [...] [mas que se manifestam em outras atividades infantis]. Em terceiro, a atividade-guia é uma atividade da qual depende intimamente, num determinado período de desenvolvimento, as principais mudanças psicológicas observáveis da personalidade da criança. (LEONTIEV, 1981 apud PRESTES, 2010, p.162).

Já em 1933, referindo-se à brincadeira, Vigotski estabelecia a diferença entre atividade predominante, isto é, a mais frequente, e atividade principal, ou seja, a que estabelece "a linha principal do desenvolvimento na idade pré-escolar" (VIGOTSKI, 2008, p.24).

Posteriormente, Elkonin (1987), embasado nos estudos de Vigotski e Leontiev, buscou esclarecer essa relação e investigou qual a atividade dominante, isso é, atividade-guia, em cada um dos diferentes períodos da vida. Definiu características e forças motrizes que possibilitam a passagem da atividade dominante de uma etapa à outra, estruturando esse processo em três grandes períodos, cada um dos quais subdivididos em dois conjuntos, um relativo à esfera motivacional e das necessidades, e o outro à esfera das possibilidades técnicas e operacionais: 
a. Na primeira infância, do ponto de vista motivacional, a criança apresenta a necessidade de comunicação emocional direta ( $1^{\circ}$ grupo). Por exemplo, ela chora, grita para se comunicar e suas atividades objetais são essencialmente manipulatórias. Gradativamente, a criança vai se apropriando dos objetivos, motivos e normas que constituem suas relaçóes sociais. E, do ponto de vista de suas possibilidades operacionais, vai passando de atividades meramente manipulatórias àquelas observadas em seu contexto social, apropriando-se desses procedimentos socialmente elaborados de ação com os objetos ( $2^{\circ}$ grupo);

b. Na infância, a necessidade na esfera motivacional refere-se à vivência dos papéis adultos, sem o ônus da realidade, o que a criança faz por meio dos jogos de papéis ( $1^{\circ}$ grupo). Do ponto de vista técnico-operacional, a criança vivencia esses jogos e inicia o desenvolvimento de atividades de estudo ( ${ }^{\circ}$ grupo);

c. Na adolescência, na esfera motivacional, a necessidade é de uma comunicação íntima pessoal ( $1^{\circ}$ grupo), sendo que suas possibilidades técnicas e operacionais envolvem atividades de estudo e formação profissional ( $2^{\circ}$ grupo).

Considerando-se o objeto de reflexão proposto no presente estudo, destacase, a seguir, o jogo protagonizado, também denominado jogo de papéis. Utilizase esse termo para designar a brincadeira infantil não estruturada, com regras subentendidas, papéis definidos, por meio das quais as crianças reproduzem os papéis sociais adultos com o intuito de inserção na sociedade.

No jogo de papéis, a criança não tem como preocupação central aprender a usar os objetos humanos ou conseguir realizar as operaçôes genuínas dos adultos. $\mathrm{O}$ motivo desses jogos está no processo em si. A criança não representa um adulto com determinada profissão ou açóes/operaçóes próprias do mundo dos adultos, como cozinhar/cortar os temperos. $\mathrm{Na}$ verdade, essas açóes/operaçóes são meios para que ela possa vivenciar, nas relaçóes que estabelece com outras crianças, aquelas observadas entre os adultos ou entre os adultos e as crianças.

[...] no jogo protagonizado influi, sobretudo, a esfera da atividade humana, do trabalho e das relaçôes entre as pessoas e [...], por conseguinte, o conteúdo fundamental do papel assumido pela criança é, precisamente, a reconstituição desse aspecto da realidade. (ELKONIN, 2009, p.31).

Por isso, o jogo protagonizado náo se configura como atividade espontânea, uma vez que se trata de uma produção das crianças com base nas relaçóes que elas observam/estabelecem com os adultos, e entre os adultos e as crianças, o que confere grande importância a essas relaçóes (ELKONIN, 2009). Portanto, a reconstrução do papel de adulto, escolhido pela criança nos jogos de papéis, está 
atrelada às suas condiçôes e relações concretas de vida. É necessário que a criança realize as diversas ações que esse papel demanda socialmente e, em decorrência, desenvolva as operaçóes que envolvem essas açóes.

A conversão da menina em mãe, e da boneca em filha, dá lugar a que os atos de dar banho, dar de comer e preparar a comida se transformem em responsabilidades da criança. Nessas açôes [estão implícitas diversas operaçôes, como preparar a água do banho, esfriar a papinha do bebê, etc.] manifesta-se então a atividade da mãe com o filho, seu amor e sua ternura, ou até o contrário: isso depende das condiçóes concretas de vida da criança, das relaçóes concretas que a circundam. (ELKONIN, 2009, p. 404-405).

Ainda, para o autor, o conteúdo fundamental dos jogos de papéis são as normas de conduta que permeiam as relaçóes entre os adultos, e são vivenciadas pela criança ao interpretar e submeter-se às regras que o papel de adulto exige. As relaçóes baseadas nas regras são fonte do desenvolvimento da moral infantil. A criança tem uma liberdade relativa nesse momento porque precisa adequar sua conduta ao papel que interpretará, seguindo as regras que dele decorrem.

Ao perceber as limitaçóes produzidas pelo que quer e pelo que não pode realizar, a criança avança em seu desenvolvimento, criando um mundo fictício no qual realiza suas necessidades por meio da imaginação em seus jogos de papéis. Surgem oportunidades para desvincular o pensamento das situaçóes concretas. $\mathrm{O}$ jogo de papéis oportuniza "[...] uma situação de transição entre a ação da criança com objetos concretos e suas açóes com significados.” (OLIVEIRA, 2011, p. 69).

A capacidade da criança de dominar seu próprio comportamento, controlando-o para alcançar determinado fim nas situaçôes de jogos de papéis, tem uma importância fundamental no desenvolvimento cognitivo infantil, por produzir uma zona de desenvolvimento iminente ${ }^{4}$.

[...] a criança sempre se comporta muito além do comportamento habitual para sua idade. Ela age como se fosse mais velha, maior, mais forte, mais capaz do que é na

4 A expressão "zona de desenvolvimento iminente" (ZDI) sustenta o conceito que se refere a "[...] processos que, no curso do desenvolvimento das mesmas funçóes, ainda não estão amadurecidos, mas já se encontram a caminho, já começam a brotar; amanhã, trarão frutos; amanhã, passarão para o nível de desenvolvimento atual." (VIGOSTKI, 2004, p. 485 apud PRESTES, 2010, p. 173). ZDI é o que conhecemos por ZDP nas traduçóes anteriores a de Prestes (2010), especialmente no livro "A formação social da mente" (VIGOTSKI, 1998). 
realidade. Ela age ou tenta agir como um adulto em relação aos objetos e conceitos do mundo adulto, do universo humano. Assim, tendo como referência o comportamento do adulto, [...] [o jogo de papéis] contém, de forma condensada, todas as tendências do desenvolvimento posterior da criança. (ROSSLER, 2006, p. 60-61).

Dessa forma, a brincadeira liberta a criança de suas limitaçóes situacionais, ainda que exija o respeito às regras de funcionamento de cada papel, e lhe possibilita experiências que, ao serem vividas sem os entraves da realidade, abrem caminho para futuras aprendizagens.

A relação do jogo com o desenvolvimento é a da aprendizagem para o desenvolvimento. Por trás do jogo estão as mudanças de necessidades e as mudanças de consciência de caráter mais geral. O jogo é uma fonte de desenvolvimento e cria zonas de evoluçáo imediata. (ELKONIN, 2009, p.424).

Assim como a aprendizagem orienta e estimula processos internos de desenvolvimento, o jogo de papéis também o propicia, por provocar novas necessidades que impulsionam mudanças evolutivas. Portanto, é importante que se propiciem condiçóes para que a brincadeira de papéis sociais, isso é, o jogo protagonizado, seja vivenciada pelas crianças dos três aos seis anos. As possibilidades de engendrar o desenvolvimento infantil por meio dos jogos protagonizados se abrem, uma vez que esse brincar já é um contexto de aprendizagem, pois propicia generalizaçóes de conceitos e permite que a criança viva as relaçóes que observa no seu entorno,atribuindo significados do mundo dos adultos aos objetos (ELKONIN, 1998).

\section{O papel da escola}

A ação pedagógica na Educação Infantil, com base na Psicologia HistóricoCultural, exige a apropriação dos conhecimentos teóricos que a fundamentam, e consequentemente a valorização dos jogos protagonizados, como formas de experimentação infantis essenciais para o desenvolvimento das funçóes psíquicas superiores.

Esses jogos exercem grande influência em todas as facetas do desenvolvimento, pois, neles também se formam níveis mais elevados de percepção, memória, imaginaçáo, 
processos psicomotores, processos verbais, elaboração de ideias e de sentimentos, etc., auxiliando a passagem do pensamento empírico concreto para formas mais abstratas de pensamento, premissa básica da complexa aprendizagem sistematizada. (MARTINS, 2007, p. 74).

As funçôes psíquicas superiores que se manifestam concretamente nas relaçôes sociais não se desenvolvem espontaneamente, exigem a interação social. As situaçóes que promovem seu desenvolvimento precisam ser oportunizadas ao indivíduo, e a escola tem grande responsabilidade nesse processo, pois, compreendendo-o, legitima a importância de focalizar esses processos funcionais ao desenvolver suas práticas pedagógicas.

Portanto, o grau de complexidade requerido nas açóes dos indivíduos e a qualidade das mediaçóes disponibilizadas para sua execução representam os condicionantes primários de todo o desenvolvimento psíquico. Em suma, funçóes complexas não se desenvolvem na base de atividades que não as exijam e as possibilitem. (MARTINS, 2013, p. 276).

É importante observar que não é possível estabelecer uma correspondência linear entre as ações pedagógicas e o desenvolvimento dos processos funcionais.

Ou seja, do ponto de vista pedagógico, não se trata do planejamento de açóes que visem ora ao desenvolvimento de dada funçáo ora ao de outra - uma vez que as mesmas operam em unidade, orquestrando a atividade em curso. Trata-se, entáo, da promoçáo de atividades ricas em possibilidades de aprendizagens que promovam desenvolvimento [...] (MARTINS, 2013, p. 307).

Destaca-se, assim, não só a importância do professor como mediador, mas a necessidade de compreender o desenvolvimento humano como objeto central para a organização dos processos educativos que realmente promovam e efetivem o desenvolvimento da criança.

Nesse sentido, os jogos de papéis, atividade-guia na faixa etária dos 3 aos 6 anos, constituem-se em necessidade para o desenvolvimento psíquico infantil. Assim, abrir espaços para que essa atividade ocorra e compreender sua importância é fundamental nessa faixa etária.

Mas, o que dizem as pesquisas sobre a apropriaçáo dos pressupostos de Elkonin na prática pedagógica da criança pequena? 


\section{O Estado do conhecimento}

As pesquisas sobre o Estado do conhecimento verificam os aspectos destacados na produçấo acadêmica em dado campo do conhecimento. Com esse intuito, buscaram-se as pesquisas acervadas na Biblioteca Digital Brasileira de Teses e Dissertaçóes, entre os anos de 2004 a 2014, referentes à periodização do desenvolvimento psíquico, na faixa etária dos 3 aos 6 anos, que abordam os estudos de Daniil Borisovich Elkonin (1904-1984). Ao utilizar-se como busca as palavraschaves "Elkonin" e "jogos protagonizados", foram selecionados oito trabalhos, dos 23 referentes a Elkonin. As dissertaçóes de mestrado foram publicizadas nos anos de 2005, 2006, 2007, 2008, 2010 e 2011 e as teses de doutorado em 2003 e 2009. Apresentam-se, a seguir, suas principais considerações.

Sobre o brincar: O brincar é importante e significativo para as crianças de 4 a 5 anos. Existem diferenças entre o brincar em casa e na instituição (LEAL, 2003). No contexto escolar, o faz-de-conta constitui-se na principal brincadeira (ARAUJO, 2008). Entretanto, o docente valoriza a brincadeira por ele planejada e dirigida, a qual objetive a aprendizagem e o treino de habilidades. A brincadeira livre é compreendida como "bagunça" apenas tolerada, nunca estimulada no ambiente da sala de aula (MARTINS, 2009) .

A análise sobre como os professores compreendem a maneira das crianças se apropriarem do brinquedo para criar situaçóes lúdicas, revela que pais e professoras atribuem um papel fundamental ao brinquedo e à brincadeira, como facilitadores do ensino e promotores do desenvolvimento infantil. No entanto, ambos foram eximidos dos seus aspectos lúdicos e utilizados para atingir objetivos relativos a conteúdos escolares e não escolares, com caráter instrumental por colaborar na formação da criança como futuro trabalhador (ÁLVARES, 2011). Assim, é indispensável que família, escola e criança redescubram a magia do brinquedo e da brincadeira (ÁLVARES, 2011).

Compreensão sobre o brincar e a prática pedagógica: As interações durante o jogo protagonizado são essenciais para a expressão e o desenvolvimento da singularidade da criança entre 4 e 6 anos. Durante o jogo emergem importantes elementos observados pelo modo como as crianças se conduzem nos momentos de negociaçáo, suas posturas diante dos colegas nas atitudes de afastamento e de aproximação, no convite para mudar de lugar com o parceiro, nas relaçóes de poder, no modo como realizam suas protagonizações, bem como nos processos criativos na elaboração de argumentos e na reconstrução das relaçóes sociais (SOUZA, 2010).

Trata-se da tese de doutorado de Cristina Amorim Martins. 
É interessante que se ofereça à criança uma atividade lúdica na qual ela seja livre para experimentar, criar e singularizar-se por meio de suas interaçóes (SOUZA, 2010). Assim, por exemplo, a brincadeira de faz-de-conta de escolinha, com crianças em torno de 6 anos, favorece o uso de regras quando o papel pretendido é legitimado pelos demais participantes. Nesses casos, há interação e a brincadeira prospera predominando regras do tipo reproduzidas, quando o papel de aluno e/ou de figuras de autoridade retrata o vivido pelas crianças e as regras construídas, as quais exigem negociação de sentidos e significados para que acordos sejam feitos e embates resolvidos (AMBRA, 2005). Portanto, brincar de faz-de-conta propicia uma oportunidade para que as crianças se preparem para o futuro, aprendendo a conviver (AMBRA, 2005).

Por não compreenderem a importância do brincar como atividade principal, por meio da qual se desenvolvem processos psicológicos que promovem a transição para um novo e mais elevado nível de desenvolvimento, as professoras deixam de oportunizar preciosos momentos para o brincar e de mediar situaçóes que desafiem as crianças a verbalizar durante as brincadeiras (MOCHIUTTI, 2007).

Maior investimento na formação inicial e continuada docente: Martins (2009) aponta o comprometimento da qualidade do trabalho docente por razóes como a ausência de uma reflexáo crítica sobre o conceito de criança e sobre a postura adultocêntrica da escola e da sociedade, bem como a inexistência de formação em serviço para a superação das dificuldades. Comprova, portanto, a necessidade da formação inicial reflexiva e crítica sobre esses aspectos, ratificando a posição de outros autores (LEAL, 2003; ARAUJO, 2008). Os processos de formação precisam do apoio dos dirigentes públicos, valorizando e propiciando condiçôes para a participação docente em eventos científicos, publicaçóes, intercâmbios, grupos de estudo e cursos de graduação e pós-graduação (LEAL, 2003).

Há necessidade de um programa de formação que redefina o papel da Educação Infantil e propicie a elaboraçáo coletiva da proposta educativa, instrumentalizando professoras e professores para o trabalho e, consequentemente, elevando a qualidade do atendimento às crianças. A valorização do brincar, assim como as necessidades e o desenvolvimento das crianças devem ser objeto de discussão coletiva, orientando as reflexóes sobre os caminhos pedagógicos que promoverão o desenvolvimento e a aprendizagem nessa faixa etária (LEAL, 2003; AZEVEDO, 2006).

Mochiutti (2007) sugere aprofundar o debate sobre as açóes políticopedagógicas viabilizadas no interior dos cursos de formação em nível superior dos professores que atuam ou atuarão na Educação Infantil. Azevedo (2006) ressalta ainda a importância de que a Educação Infantil seja um fim, e não uma mera preparação para o Ensino Fundamental. Propóe que o professor seja instruído de forma a considerar a criança como sujeito cultural, social e histórico. 
O brincar como estratégia escolar: Verifica-se que os docentes utilizam o jogo na Educação Infantil como momento de recreação e ocupação do tempo ou como atividade pedagógica para atingir objetivos escolares, desconhecendo o jogo protagonizado em si, como fator importante para o desenvolvimento psicológico da criança pequena (SOUZA, 2010; MOCHIUTTI, 2007; ÁLVARES, 2011).

Ao prevalecer o tempo institucionalizado em detrimento do tempo da e para a criança, reduzem-se as possibilidades de vivência plena de atos de criação e imaginação, reproduzindo as práticas educativas uniformes que ocorrem no Ensino Fundamental (MOCHIUTTI, 2007).

Mesmo quando a escola se organiza de modo a potencializar aspectos do imaginário, do lúdico, do artístico e do criativo, em tarefas que os privilegiam, esses aparecem em segundo plano, priorizando-se o aspecto escolar, em razão da homogeneização no formato e na dinâmica dos trabalhos, engessando o tempo e o espaço (MOCHIUTTI, 2007). Ao conceber o jogo protagonizado como uma estratégia de ensino de conteúdos escolares verifica-se a perda das principais características do lúdico, tais como imprevisibilidade, ausência de seriedade e de consequências (SOUZA, 2010).

Portanto, é importante repensar a prática que prioriza as atividades mais escolarizantes, legitimando o que é mais e o que é menos importante à criança aprender, e que coloca em segundo plano as experiências que focalizam a ação lúdica e criativa, uma vez que nesse modelo a Educação Infantil não é pensada pelos saberes próprios da infância (MOCHIUTTI, 2007).

$\mathrm{O}$ cenário aqui delineado demonstra a relevância de ampliar o número de pesquisas sobre o papel do brincar, assim como revela a ausência de trabalhos que visem analisar a presença de jogos protagonizados como atividade estruturante do psiquismo infantil.

\section{A pesquisa de campo}

Com base no referencial apresentado, realizou-se uma pesquisa de campo, envolvendo crianças de 5 a 6 anos de idade, que frequentavam a Educação Infantil, com o objetivo de verificar se e como os jogos de papéis acontecem no processo pedagógico desenvolvido em uma escola municipal de uma cidade da região sudoeste do Estado do Paraná.

A pesquisa foi aprovada pelo Comitê de Ética em Pesquisa da Universidade Estadual do Oeste do Paraná (UNIOESTE) (Parecer 898.472, processo CAAE $\left.n^{\circ} 34228314.9 .0000 .0107\right)$. Considera a subjetividade dos sujeitos, a percepção do pesquisador, os acontecimentos do ambiente que os cerca, e os fenômenos 
estudados não são reduzidos a simples variáveis, mas sim representados em sua totalidade, dentro de seus contextos (FLICK, 2009), não se apoiando em situaçóes artificiais criadas em laboratório, mas sim em práticas e interações dos sujeitos na vida cotidiana. Assim, pode ser considerada pesquisa qualitativa, envolvendo um Estudo de Caso, organizado em duas etapas: na etapa documental, foi analisado o Projeto Pedagógico da escola; na segunda etapa, os dados foram coletados por meio de observaçóes e anotaçóes em caderno de campo, durante 11 dias, totalizando 11 encontros, num total aproximado de 14 horas-relógio, para posterior análise.

A instituição pública de ensino envolvida foi sugerida pela Secretária Municipal de Educaçáo, quando feita a solicitação para o desenvolvimento da pesquisa, por sua disponibilidade e por apresentar características comuns a qualquer outra escola do município. Desse modo, considera-se que uma escola e um grupo de crianças "[...] contém a totalidade social e a expressa nas suas açóes, pensamentos e sentimentos. Assim, o processo apreendido [...] pode revelar algo constitutivo de outros sujeitos que vivem em condiçóes semelhantes." (AGUIAR, 2001, p. 140).

$\mathrm{Na}$ Escola Municipal de Educaçáo Infantil, a diretora informou professora, turma e turno para a realização das observaçóes, por ser a única turma de préescolar no período da tarde, frequentada por crianças entre 5 e 6 anos. Objetivavase verificar como eram desenvolvidas e de que forma as atividades lúdicas inseriamse no Projeto Pedagógico da escola. Buscavam-se respostas às perguntas:

- Na interação escolar entre as crianças aparecem jogos de papéis?

- Na rotina escolar estão previstas e/ou organizadas intencionalmente situaçóes em que se vivenciam jogos de papéis?

- Quais brincadeiras e/ou atividades compóem o lúdico no espaço escolar?

\section{O lúdico na proposta pedagógica da escola investigada ${ }^{6}$}

A análise da Proposta Pedagógica da escola revelou um texto fragmentado e com ênfase no Ensino Fundamental, quando, na verdade, deveria estar voltada à Educação Infantil. Não esclarece as concepções de criança, de infância, de brincadeira e de ensino-aprendizagem que apoiam o trabalho pedagógico da escola. Refere-se apenas a que as crianças aprendem e desenvolvem nas relaçóes

6 Por questốes éticas optou-se por omitir o nome da escola e, portanto, por não citar o Projeto Pedagógico da escola investigada, nas referências. 
de trocas e do brincar. A opção pelos conteúdos escolares não é justificada, bem como sua importância para a aprendizagem e para o desenvolvimento infantil.

As citaçōes, a seguir, foram extraídas do Projeto Pedagógico da escola pesquisada. O texto cita Vygotsky, entendendo a criança "[...] como ser social inserido em uma cultura, e [afirma que] consequentemente será através da interação com o outro que a criança potencializa sua capacidade de se desenvolver e de aprender." Entretanto, observa-se uma incoerência ao colocar, em outro trecho, que "a criança é capaz de expressar-se 'desde sempre' (sic) através dos pensamentos, sentimentos e da imaginação", não contemplando a questão da historicidade na constituição do sujeito, que parece ser compreendido como pronto e acabado.

Quanto aos encaminhamentos metodológicos, o projeto orienta que os limites de cada criança sejam respeitados e, "[...] que cada uma tenha seu desenvolvimento, interesses e necessidades peculiares satisfeitos, uma vez que vive num contexto 'sócio-cultural' que precisa ser considerado." Sugere, ainda, para

\section{[...] observar a criança nas atividades que realiza (jogos, condutas espontâneas, etc.); propor situaçóes significativas às crianças, onde elas se utilizem do seu conjunto de ideias, relacionando e garantindo um novo significado; valorizar as manifestaçôes espontâneas da criança (o "faz-de-conta", as imitaçóes, os desenhos, as histórias, as narrativas, a fala, etc.); criar espaços onde possa ocorrer um planejamento coletivo que possibilite decidir em grupo as atividades a serem realizadas; contribuir para ampliar a leitura de mundo de cada criança.}

Esse é o único trecho em que o faz-de-conta é citado com a indicação de que seja valorizado, porém não como uma atividade promovedora do desenvolvimento infantil e de essencial importância na rotina da sala de aula.

\section{As atividades lúdicas no cotidiano escolar}

No primeiro dia de observação, permaneceu-se na escola durante todo o período vespertino. Verificou-se, então, que além do intervalo para o recreio, a escola só permitia que as crianças brincassem no Dia do Brinquedo, que ocorria às sextas-feiras na última hora-relógio do período da tarde, horário em que as observações passaram a se concentrar. Pode-se constatar a não manifestação desses episódios na escola, em outros momentos diferentes do cotidiano pedagógico. A ênfase do trabalho pedagógico concentrava-se nas atividades ditas escolares, fato 
amplamente ratificado na literatura por Leal (2003), Azevedo (2006), Mochiutti (2007), Martins (2009) e Álvares (2011).

Constatou-se ainda que, no Dia do Brinquedo, cada criança limitava-se a levar um brinquedo para a escola, permanecendo na própria sala de aula. Essa limitação de tempo e espaço refletia-se no brincar, cerceando a evolução para jogos de papéis. Assim, nas 14 horas de observação do brincar nessa escola, as crianças empurravam carrinhos, utilizavam jogos eletrônicos trazidos de casa, montavam quebra-cabeças da escola, imitavam animais ou brincavam de pegapega. Nas dez semanas de observação, podem-se registrar, em caderno de campo, apenas duas brincadeiras que envolviam jogo de papéis, descritas a seguir:

A menina A.M (5 anos) brinca de vendedora e de atendente de caixa com o brinquedo caixa registradora, oferecendo um kit de maquiagem às amigas: " - Quem quer comprar?” Em seguida, uma colega senta-se perto dela no sofá e adquire o kit de maquiagem. Imitam papéis de adultos que conversam enquanto pintam suas unhas. $\mathrm{O}$ jogo se encerra.

No segundo episódio, outra criança pega a caixa registradora, passa a imitar uma atendente de lanchonete e anuncia para os demais: “ - Quem quer comprar? Você quer? O que você deseja?” As crianças que participam do jogo compram lanches, comem rapidamente, conversam e saem para brincar de outra coisa.

Nesses jogos, as crianças retratam situaçóes já vivenciadas em seu cotidiano em que adultos realizam atividades profissionais de vendedora e atendente de lanchonete.

[...] isso significa que a criança vê o adulto, sobretudo, pelo lado de suas funções. Quer atuar como o adulto, sente-se totalmente dominada por esse desejo. Precisamente sob a impressão desse desejo muito geral, primeiro mediante as sugestôes do adulto (o educador ou os pais), começa atuando como se também ela o fosse. Essa sensação é tão grande, que basta uma pequena alusão para que a criança se converta alegremente, claro que no aspecto puramente emotivo, em adulto. É pela força dessa sensação que se explica a facilidade com que as crianças assumem os papéis dos adultos. (ELKONIN, 2009, p. 404).

A principal característica da atividade lúdica no jogo de papéis é o fato de a criança criar uma situação fictícia para representar um papel de adulto, conforme o sentido que ela lhe atribui. Assim, nos fragmentos relatados, as protagonizaçóes infantis dos papéis de vendedora e compradora/consumidora partem de situaçóes vivenciadas por elas, em que gestos e posturas retratam aspectos relacionais do mundo adulto. Essas relaçóes que os adultos estabelecem entre si, ao utilizarem 
os objetos, constituem o foco principal e se manifestam nas relaçóes que a criança estabelece com outras crianças, no desenvolvimento do jogo protagonizado.

Porém, não se trata de mera cópia dos elementos da realidade, há um processo de imaginação em atividade que permeia a reelaboração das vivências infantis, e se manifesta nos jogos de papéis. "É uma combinação dessas impressóes [vivenciadas] e, baseada nelas, a construção de uma realidade nova que responde às aspiraçóes e aos anseios da criança." (VIGOTSKI, 2009, p. 17). Assim, embora a criança conheça todos os elementos dessa reconstrução, os rearranja de maneira inusitada, de forma a atender aos seus desejos.

O típico da situação "fictícia" é a transferência das significações de um objeto a outro e as açôes reconstitutivas em forma sintética e abreviada das açôes reais no papel de adulto adotado pela criança. Isso chega a ser possível quando se baseia na disparidade, que aparece na idade pré-escolar, entre o que se vê e o sentido que se lhe dá. (ELKONIN, 2009, p. 200).

Essa disparidade entre o que a criança vê e o sentido que é atribuído ao objeto tem profundo significado emocional para a criança. $\mathrm{O}$ fundamental é compreender que esses jogos envolvem possibilidades de aprendizagem e, embora sejam espontâneos, resultam de processos que se relacionam com as vivências infantis, emocionalmente mais significativas. Considerando que as escolhas dos papéis estão relacionadas aos significados que assumem para a criança, poder-se-ia pensar que esses primeiros papéis de adulto, que apareceram da forma abreviada ora relatada, de alguma forma relacionam-se com suas vivências cotidianas, podendo estar ligados às profissóes de seus pais.

Para se manifestarem, os jogos protagonizados requerem alguns elementos mediadores, internos e externos. Um importante "[...] mediador externo à criança são os brinquedos e artefatos (objetos, indumentárias, etc.) e, em especial, a presença de outras crianças.” (OLIVEIRA, 2011, p. 143). Já o elemento mediador interno "[...] são, por exemplo, as memórias de situações, as percepções e sensaçóes, as expectativas e necessidades das crianças, que vão se apresentando ao longo da experiência cotidiana" (OLIVEIRA, 2011, p. 143). Na situação escolar observada, embora não houvesse mediadores externos, os papéis observados decorrem de mediadores internos fundamentais ao revelar memórias de situaçóes vivenciadas pelas crianças.

Quanto mais se consegue propiciar momentos e atividades que permitem interaçôes de pequenos grupos, mais se auxilia 
a criança a aprender como se conduzir nas relaçóes com diferentes parceiros. Com isso são criadas oportunidades para a construçấo de conhecimentos e de sentidos pessoais sobre o mundo e sobre si. (OLIVEIRA, 2011, p. 143).

Trata-se, portanto, da vivência das relaçóes que a criança observa nas situaçóes cotidianas, colocando-se na perspectiva do adulto, satisfazendo a necessidade emocional infantil de antecipar esses papéis, situando-se em uma nova zona de desenvolvimento psíquico iminente, e, como tal, profícua e necessária para o desenvolvimento psíquico infantil.

\section{Algumas considerações finais: jogos protagonizados e desenvolvimento psíquico na Educação Infantil}

As escolas de Educação Infantil enfatizam o trabalho pedagógico voltado ao saber escolar e deixam de lado o brincar como atividade lúdica e criativa. Quando ocorrem, as atividades lúdicas são utilizadas apenas como estratégias para a apropriação do saber escolar (LEAL, 2003). Na mesma direção, as pesquisas de Azevedo (2006), Mochiutti (2007) e Araújo (2008) apontam para o desconhecimento docente quanto à importância do brincar para o desenvolvimento infantil, assinalam a especificidade das brincadeiras e a importância de que o professor compreenda que a Educação Infantil não é uma etapa preparatória para o Ensino Fundamental. Essas consideraçóes ratificam-se na presente pesquisa.

Se pouco se observa quanto à presença do brincar na Educação Infantil, a situação agrava-se com a ausência quase total de jogos protagonizados, os quais envolvem temas trazidos pela própria criança com base nas relaçóes que ela observa entre os adultos. Essa ausência é provocada pela forma como as atividades da escola se organizam, não possibilitando tempo e espaço para que os jogos de papéis ocorram, o que revela o desconhecimento da equipe de ensino quanto à contribuição pedagógica e emocional dessas vivências pela e para a criança.

A Pedagogia Histórico-Crítica propóe que o desenvolvimento seja guiado pela educação, isso é, por uma "[...] sistematização da educação de forma que esta possa dirigir regularmente os ritmos e o conteúdo do desenvolvimento por meio de açôes que exercem influência sobre este." (DAVIDOV; SHUARE, 1987, p. 151). Esse processo concretiza-se pela mediaçáo docente. Ao professor cabe desenvolver tarefas que atuem como mediadoras entre o ponto de partida discente - conhecimento empírico, cotidiano, o que o aluno já traz - e o ponto discente de chegada - apropriação do conhecimento científico. 
A Psicologia Histórico-Cultural destaca que atividade e consciência articulamse reciprocamente. Propóe, ainda, que a atividade-guia que se articula ao desenvolvimento psíquico da criança dos 3 aos 6 anos é o brincar, necessariamente associado à criação de uma situação fictícia, em que a criança tenha oportunidade de vivenciar relaçóes adultas observadas em seu contexto, por meio de papéis em que as protagoniza. Essas vivências referem-se a situaçóes de fundamental importância para a formação de suas neoconexóes psíquicas, por ligar-se ao desenvolvimento das funçóes intelectuais e ao desenvolvimento da esfera afetiva.

O jogo protagonizado é uma oportunidade para realizar as tendências e os desejos irrealizáveis que surgem na criança pré-escolar, os quais são anteriores ao jogo e sem os quais o jogo inexistiria. Vivenciar o lúdico propicia um salto no desenvolvimento da criança, que passa a comportar-se com maior maturidade, procurando resolver a nova situação que protagoniza. Ela precisa solucionar o conflito gerado pelo que quer e pelo que não pode ainda realizar, por isso, cria um mundo imaginário no qual realiza seus desejos.

É justamente nesse mundo imaginário que surge o jogo de papéis e, principalmente, desenvolve-se a imaginação, processo psicológico especificamente humano da consciência e originário na ação da criança. A atividade mental do pré-escolar é decisivamente influenciada pela ludicidade ao realizar uma ação pressupondo outra, ou ainda, ao manipular um objeto pressupondo outro, o que faz a imaginação ser fundamental para o jogo de papéis.

Além da imaginação, os jogos protagonizados permitem o aprimoramento de novos domínios, consequentemente, desenvolvem o psiquismo: atenção, memória ativa e voluntária, vocabulário, raciocínio lógico-causal, exigindo concentração para rememorar vivências anteriores. Possibilitam, ainda, uma conduta arbitrada, ou seja, um maior controle sobre os próprios comportamentos, assegurando, assim, a gênese de aprendizagens sistematizadas mais complexas. Ao brincar de jogo de papéis, a criança reconhece suas capacidades e potencialidades, expóe suas opinióes acerca da sociedade em que vive, demonstra seus sentimentos, revela sua consciência na busca de humanizar-se.

A função social da escola está vinculada à formação do homem para viver em sociedade, sendo que os conhecimentos transmitidos devem servir para o desenvolvimento e o aprimoramento das capacidades humanas. $\mathrm{O}$ que requer aprendizagem, que, por sua vez, requer ensino, responsabilidade da escola.

Considerando que as condições históricas são complexas e se articulam ao modo de produção, "não é o homem que transforma as circunstâncias, por si só, mas enquanto as transforma, transforma-se a si próprio." (BATISTA; LIMA, 2012, p.33). Nesse sentido, a formação da criança pequena mediante a educação escolar é parte de uma totalidade maior, de um projeto político de sociedade, a 
ser transformada. É função da escola compreender e explorar as necessidades e criar incentivos, abrindo espaços e tempo na organização curricular, propiciando à criança vivências viabilizadas por meio dos jogos de papéis, para que ela avance a estágios de desenvolvimento cada vez mais evoluídos.

Dessa forma, a educação da criança pequena pode reafirmar seu caráter institucional e social, reivindicado pela sociedade, possibilitando o acesso aos conhecimentos historicamente construídos pela humanidade, necessários ao desenvolvimento das novas geraçóes.

\section{Referências}

AGUIAR, W. M. J. A pesquisa em psicologia sócio-histórica: contribuições para o debate metodológico. In: BOCK, A. M. B.; GONÇALVES, M. G. M.; FURTADO, O. (Org.). Psicologia sócio-histórica: uma perspectiva crítica em psicologia. São Paulo: Cortez, 2001.

ÁLVARES, L. O. O brinquedo em instituiçóes públicas de Educação Infantil: os significados atribuídos por pais e professoras. 2011. 148 f. Dissertação (Mestrado) - Pontifícia Universidade Católica de Goiás, Goiânia. Disponível em: <http://tede.biblioteca.ucg.br/tde_busca/arquivo. php?codArquivo=1026>. Acesso em: 15 out. 2015.

AMBRA, K. Preparando-se para o futuro: as regras elaboradas por crianças de 6 anos durante a brincadeira de faz-de-conta.2005. Dissertação (Mestrado) - Pontifícia Universidade Católica de São Paulo, São Paulo. Disponível em: $<$ http://www.pucsp.br/ pedpos/resumo/ rautor.htm?r05_001>. Acesso em: 12 out. 2015.

ARAÚJO, V. C. de. A brincadeira na instituiçáo de Educação Infantil em tempo integral: o que dizem as crianças? 2008. 138f. Dissertação (Mestrado) - Universidade Federal de Juiz de Fora, Minas Gerais. Disponível em: <http:// www.uff.br/ppge/files/2010/07/Dissertacao_Viviam.pdf>. Acesso em: 23 nov 2015.

AZEVEDO, J. I. A. C. de. A criança e o brincar: um estudo sobre as concepçôes das educadoras infantis. 2006. 119f. Dissertação (Mestrado) Universidade Regional de Blumenau, Santa Catarina. Disponível em: <http:// proxy.furb.br/tede/tde_busca/arquivo.php? codArquivo=200>. Acesso em: 15 out 2015 . 
BATISTA, E. L.; LIMA, M. R. A pedagogia histórico-crítica como teoria pedagógica transformadora: da consciência filosófica à prática. In: MARSIGLIA, A. C. G.; BATISTA, E. L. (Org.). Pedagogia histórico-crítica: desafios e perspectivas para uma educação transformadora. Campinas: Autores Associados, 2012. p. 01-36.

DAVIDOV, V; SHUARE M. (Org.). La psicologia evolutiva y pedagógica en La URSS (antologia). Moscou: Progresso, 1987.

ELKONIN, D. B. Psicologia do jogo. 2. ed. São Paulo: Martins Fontes, 2009.

- Sobre el problema de la periodización del desarrollo psíquico en la infancia. In: DAVÍDOV, Vasili; SHUARE, Marta. La psicologiaevolutivay pedagogica em La URSS.URSS. Editorial Progreso, 1987. p. 104-124.

FLICK, Uwe. Introdução à pesquisa qualitativa. Porto Alegre: Artmed, 2009.

LEAL, L. L. L. O brincar da criança pré-escolar: estudo de caso em uma escola municipal de Educação Infantil. 2003. 227 f. Tese (Doutorado) - Universidade Federal de São Carlos, São Paulo. Disponível em: <http://www.bdtd.ufscar. $\mathrm{br} / \mathrm{htdocs} /$ tedeSimplificado//tde_busca/arquivo.php?codArquivo=287 > . Acesso em: 30 dez. 2016.

LEONTIEV, A. N. O desenvolvimento do psiquismo. Lisboa: Livros Horizontes, 1978.

. Os princípios psicológicos da brincadeira pré-escolar. In: VIGOSTKI, L. S.; LURIA, A. R.; LEONTIEV, A. N. Linguagem, desenvolvimento e aprendizagem. São Paulo: Ícone: 2014. p. 119-142.

LURIA, A. R. Curso de psicologia geral: sensações e percepção; psicologia dos processos cognitivos. 2.ed. Rio de Janeiro: Civilização Brasileira, 1991, v. II.

MARTINS, C. A. A participaçáo de crianças e professora na constituiçáo da brincadeira na Educaçáo Infantil. 2009. 283 f. Tese (Doutorado) Universidade Federal do Ceará, Fortaleza. Disponível em: <http://www.teses. ufc.br/tde_busca/arquivo.php? codArquivo =3042>. Acesso em: 12 out 2015 .

MARTINS, L. M. O desenvolvimento do psiquismo e a educaçáo escolar: contribuiçôes à luz da psicologia histórico-cultural e da pedagogia históricocrítica. São Paulo: Autores associados, 2013.

MOCHIUTTI, S. Educação Infantil e cultura lúdica: um olhar sobre a prática pedagógica das professoras da Escola de Aplicação da UFPA.2007. 
164f. Universidade Federal do Pará, Belém. Dissertação (Mestrado) Disponível em: <http://www.ppged.belemvirtual.com.br/ arquivos/File/ dissertacoes2007/Solange_Mochiutti.pdf>. Acesso em: 15 out 2015.

OLIVEIRA, Z. de M. de R. Jogo de papéis: um olhar para as brincadeiras infantis. São Paulo: Cortez, 2011.

PRESTES, Z. R. Quando náo é quase a mesma coisa: uma análise de traduçôes de Lev Semionovitch Vigotski no Brasil, repercussôes no campo educacional. 295 f. Tese (Doutorado) - Faculdade de Educação, Universidade de Brasília, Brasília, 2010.

VYGOTSKY, L. S. A formaçáo social da mente. São Paulo: Martins Fontes, 1998.

VIGOTSKI, L. S. A brincadeira e o seu papel no desenvolvimento psíquico da criança. Tradução de Zoia Prestes. Revista Virtual de Gestáo de Iniciativas Sociais, 8, 23-36. (Original Work Published in 1933), jun. 2008. Disponível em $:<$ https://isabeladominici.files.wordpress. com/2014/07/revista-educinfant-indic-zoia.pdf>. Acesso em: 19 fev. 2017.

. Imaginação e criaçáo na infância: ensaio psicológico, livro para professores. Tradução de Zoia Prestes. São Paulo: Ática, 2009.

ROSSLER, J. H. O papel da brincadeira de papéis sociais no desenvolvimento do psiquismo humano. In: ARCE, A.; DUARTE, N. (Org.). Brincadeira de papéis sociais na educaçáo infantil: as contribuiçóes de Vigotski, Leontiev e Elkonin. São Paulo: Xamã, 2006.

SOUZA, R. A. de. Um estudo sobre o processo de singularização de crianças através do jogo protagonizado. 2010. 120 f. Dissertação (Mestrado) Universidade Federal do Ceará, Fortaleza. Disponível em: <http://www.teses. ufc.br/tde_busca/arquivo.php?codArquivo=4616>. Acesso em: 12 out. 2014. 



\title{
Pesquisa com crianças: entre a experiência no campo e a escrita do texto
}

\author{
Research with children: \\ between the experience in the field and the writing of the text
}

\author{
Irene Carrillo Romero BEBER ${ }^{1}$ \\ Maria Carmen Silveira BARBOSA ${ }^{2}$
}

\begin{abstract}
Resumo
A tessitura do texto foca em dois momentos do desenvolvimento da pesquisa com crianças. O primeiro é relativo ao processo de observação: estar com as crianças numa atitude de escuta, marcada pela presença física do pesquisador na captura das cenas e episódios e nos processos de interação entre o pesquisador e os sujeitos da pesquisa. $\mathrm{O}$ segundo diz respeito ao processo de distanciamento da escrita, a teorização das açóes vivenciadas no campo de pesquisa. Os dados gerados indicam que pesquisar com crianças envolve interaçóes afetivas e corpóreas, ou seja, a presença pessoal afeta e é afetada pelas experiências vividas no campo.
\end{abstract}

Palavras-chave: Pesquisa. Escrita. Educação Infantil. Corporeidade.
Abstract

The writing of the text focuses on two moments in the development of research with children. The first moment is related to the process of observation: being with the children in an attitude of listening, which is marked by the physical presence of the researcher in the capture of scenes and episodes, and in the processes of interaction between the researcher and the subjects. The second moment has to do with the process of distancing during the writing, the theorizing of actions experienced in the field of research. The data generated indicate that research with children involves affective and body interactions, i. e. the personal presence affects and is affected by the experiences lived in the field.

Keywords: Research, Writing, Children Education, Corporeity

1 Doutora em Educação da UFRGS. Professora Adjunta IV no Curso de Pedagogia, Campus de Sinop na Universidade do Estado de Mato Grosso. Atua na área de Educação, participando em projetos de pesquisa e extensão. Atualmente as interações entre adultos e crianças nos espaços da escola de Educação Infantil, com enfoque na corporeidade e nas experiências de aprendizagem com o corpo em movimento das crianças. Universidade do Estado de Mato Grosso, Campus de Sinop. Av. dos Ingás no 3001, Centro, 78550000 - Sinop, MT - Brasil. Telefone: (066) 35112100. E-mail: <irenecrbeber@gmail.com>.

2 Doutorado em Educação pela Universidade Estadual de Campinas, Brasil (2000). Professor Titular da Universidade Federal do Rio Grande do Sul, Brasil. Faculdade de Educaçấo, Departamento de Estudos Especializados. Avenida Paulo da Gama, s/no Farroupilha 90046-900 - Porto Alegre, RS - Brasil Telefone: (51) 33163099. E-mail: <licabarbosa@ufrgs.br>.

R. Educ. Públ. v. 28 n. 67 jan./abr. 2019 


\section{Abrindo a conversa}

O desafio teórico-metodológico de pesquisar com as crianças tem instigado um número cada vez maior de pesquisadores, que buscam compreender seus mundos e suas experiências. Esse processo nos coloca diante da necessidade de ampliar os nossos entendimentos acerca dos seus modos de agir, comunicar, aprender e interagir. Adentrar nesse universo é sem dúvida um dos grandes desafios aos pesquisadores que buscam pesquisar com as crianças, incluindo-as na geração de dados como protagonistas, como agentes sociais ativos de suas primeiras impressóes do mundo.

Nos últimos 20 anos, presenciamos o crescimento substancial de grupos de pesquisa, em especial os ligados aos Programas de Pós-Graduação ${ }^{3}$, que se propóem a pesquisar o universo infantil a partir de metodologias que ampliam a participação efetiva das crianças na produção e compreensão das experiências vividas. Esse volume de estudos tem potencializado igualmente o número de livros e artigos que tematizam a experiência de pesquisa com crianças; entre eles, se encontram Faria et al. (1999), Lopes da Silva, Nunes e Macedo (2002), Cohan (2005), Cruz (2008), Filho e Prado (2011) e Guimarães (2011).

Assim, este texto busca compartilhar, a partir da nossa experiência de pesquisa, os desafios de se operar com os instrumentais metodológicos da etnografia, evidenciando como a utilizaçáo desses instrumentos de pesquisa nos permitiu interagir com as crianças. Ao assumirmos uma atitude de escuta e acuidade perceptiva, pudemos compreender como a presença do pesquisador interfere, amplia vínculos, modifica o ambiente no qual a criança está inserida e como esses aspectos devem ser operacionalizados no desenvolvimento da pesquisa.

$\mathrm{Na}$ perspectiva etnográfica, o pesquisador é primeiramente percebido como um estranho ${ }^{4}$ que se insere no campo. No decorrer da investigaçáo, constrói estratégias de aproximação com o intuito de capturar as manifestações das crianças e durante o desenvolvimento da pesquisa acaba sendo capturado, envolvido nessa relação, como nos ensina Geertz (2008, p. 20): "fazer etnografia é estabelecer relaçóes". Nessa perspectiva, a ação de pesquisar com as crianças implica numa

3 No IV Seminário do Grupeci, em 2014, reuniram-se cerca de 70 grupos, com a apresentação de 200 trabalhos, divididos em cinco eixos temáticos diferentes.

4 O termo estranho aqui faz referência ao sentido de alguém que nâo pertence ao grupo. Os estudos antropológicos fazem menção a esse contexto: o estranho (ou ainda o estrangeiro) como alguém que não é do grupo, e que precisa conquistar seu espaço e estabelecer relaçôes. 
atitude de escuta do pesquisador, indispensável nos movimentos apreensão das experiências de como as crianças percebem o mundo 5 .

Ao revisarmos a produçáo nessa área, pudemos identificar que os trabalhos que abordam ${ }^{6}$ metodologicamente as dinâmicas de pesquisa com crianças com frequência abordam as complexas interaçôes dos pesquisadores com as crianças, mencionam os aspectos relativos às suas açóes, às intencionalidades e iniciativas de conhecer, bem como as trocas interativas com os demais sujeitos envolvidos.

Esses estudos refletem sobre as multiplicidades de faces presentes nas dinâmicas que envolvem a ação de pesquisar com as crianças. Como apreender os sentidos das suas experiências nas brincadeiras? Como capturar e avaliar os seus processos de aprendizagens? Como analisar e traduzir pela escrita o observado? Como narrar as cenas e os episódios, e como manter uma postura ética na pesquisa, interagir com elas sem invadir de modo excessivo seu espaço?

Neste texto, não abordaremos todos esses aspectos. No entanto, pretendemos nos deter na análise compreensiva de dois momentos igualmente significativos que permeiam o processo de pesquisa. $\mathrm{O}$ primeiro aspecto está relacionado à inserção no campo de pesquisa, à experiência de conviver com as crianças numa perspectiva de escuta, numa relação que envolve a presença física do pesquisador. É o instante em que suas estratégias de pesquisa precisam possibilitar o capturar, apreender e compreender as açôes das crianças e dos demais envolvidos na pesquisa. Esses procedimentos exigem do pesquisador uma atitude ativa e intencional em dar visibilidade às açóes e iniciativas de conhecer e se comunicar das crianças.

$\mathrm{Na}$ experiência de pesquisa vivenciada, a nossa interação se efetivou, na maioria das situaçóes, pela via da corporeidade, ou seja, na intercomunicação corporal, pelo olhar, no toque, uma comunicação não centralizada na oralidade, uma vez que as crianças pequenas não conseguem se expressar plenamente pela fala. A expressão de seus desejos é manifestada em gestos, movimentos, atitudes que evidenciam suas intencionalidades. Nesses processos, a presença física do pesquisador é um fator preponderante que em algumas situaçóes aproxima, facilita

5 Em 1989, foi publicado no Brasil um clássico artigo de Clifford Geertz denominado "Estar lá, escrever aqui”, que versa sobre a produção da antropologia no momento da escrita. Esse texto tornou-se referência na antropologia contemporânea. Também Claude Lévi-Strauss (1977) havia trabalhado com os conceitos de Olhar, escutar, ler em um livro sobre antropologia e arte. No Brasil, o antropólogo Roberto Cardoso de Oliveira inspirou-se e proferiu uma palestra com tema semelhante na UNICAMP: "O Trabalho do Antropólogo: Olhar, Ouvir, Escrever”. Nós, seguindo nessa jornada, nos inspiramos nessa dualidade complementar para refletir sobre questốes metodológicas na pesquisa com crianças.

6 Muitas teses e dissertaçōes desenvolveram metodologias e tiveram a participação efetiva das crianças. Entre elas, podermos citar Beber (2014), Vargas (2014), Gobbato (2011), Coutinho (2010) e Buss (2012). 
as interações. Em outras ocasióes, as crianças rejeitam a presença observadora do pesquisador, uma vez que ela interfere no desenvolvimento da cena ou do episódio em curso. A aceitação pela criança dessa presença observadora precisa ser conquistada e negociada, ao longo do processo de inserção no campo de pesquisa.

O segundo aspecto da pesquisa destacado neste texto está relacionado ao processo de distanciamento, o momento de teorizaçáo e de escrita dos processos vividos no campo de pesquisa. Trata-se do exercício de escrita, no qual se busca significar num outro plano as experiências e aprendizagens vivenciadas. Entendemos que a interpretação densa e criteriosa dos dados não é possível sem o esforço do distanciamento; no entanto, o exercício da escrita envolve um complexo movimento entre o distanciamento e a aproximação. Ao mesmo tempo em precisamos nos distanciar, o campo não sai de nós - pois ele está em nós. $\mathrm{O}$ processo de análise/compreensão implica necessariamente no reconhecimento das aprendizagens vividas por nós e pelas crianças no campo, ou seja, compreender em que medida fomos impactados pela experiência de pesquisa com as crianças, $o$ que elas nos mostraram com seus corpos em movimento no contexto investigado.

\section{Organização metodológica do estudo}

A experiência de pesquisa ${ }^{7}$ foi desenvolvida numa instituição pública que atende crianças de 0 a 5 anos, num município da Região Norte do Mato Grosso. O grupo constituía-se de 25 crianças, com idades entre 2 e 3 anos. Além das crianças, foram objeto de observação e análise os adultos que se revezavam no atendimento de cuidado e educação das crianças. Ao todo foram seis adultos, sendo duas professoras e quatro auxiliares. A geração dos dados se efetivou a partir da observação direta com auxílio de filmagens, fotografias e anotaçôes no diário de campo.

Com o intuito de potencializar as dinâmicas de geração dos dados, afinamos o uso dos instrumentais teórico-metodológicos da perspectiva etnográfica de Geertz (1989), da escuta sensível desenvolvida por Barbier (2007) e da abordagem fenomenológica de Merleau-Ponty (1994, 2004, 2006). A partir da composição dessa tríade metodológica, foi delineado o que, ousamos dizer, pode ser compreendido como um instrumento metodológico: o olhar em $3 D$.

7 A experiência de pesquisa culminou com a tese de doutorado em Educaçáo As experiências do corpo em movimento das crianças pequenas: Reflexōes para a pedagogia da infância, um estudo que buscou apreender as dinâmicas do corpo em movimento das crianças e as interaçốes entre adultos e crianças nos espaços da creche. 
O desafio da pesquisa era construir um olhar e uma observação densa em perspectiva, com os quais pudéssemos desenvolver um olhar ampliado de vários ângulos, uma vez que o objetivo central do estudo era evidenciar como as crianças de 2 a 3 anos manifestam sua corporeidade e, por meio das açóes autônomas e criativas, produzem suas aprendizagens, significam e recriam os objetos e os espaços. Como sinaliza Beber (2014), com o corpo em movimento, a crianças produzem narrativas que expressam suas intencionalidades e percepçóes sobre o mundo e as coisas.

Assim, ao desenvolvermos o olhar em 3D como um recurso metodológico, buscamos referência e analogia à metáfora da visão tridimensional em $3 \mathrm{D}$ utilizada pelo cinema. Nela, a formaçáo de uma imagem em três dimensóes, de fato, náo existe. $\mathrm{O}$ efeito é conseguido graças à maneira como o cérebro humano percebe as imagens. $\mathrm{Na}$ prática, para que haja uma imagem $3 \mathrm{D}$, são necessárias duas imagens sobrepostas, projetadas em ângulos diferentes. Em outras palavras, ao perceber que se tratam de duas imagens, ou imagens que não estão perfeitamente alinhadas entre si, o cérebro humano intuitivamente tenta alinhá-las e, para isso, coloca uma em primeiro plano e outra em segundo.

O resultado obtido nesse processo simula a sensação de profundidade, dando a nítida impressáo de que uma imagem está mais próxima do que a outra. Esse é um processo natural do olho humano, uma vez que vemos em três dimensóes. $\mathrm{O}$ cinema buscou desenvolver tecnologias que reproduzissem a visão humana, visto que o olho e o cérebro constituem uma dimensão tridimensional, em perspectiva.

Nessa perspectiva, o instrumental metodológico do olhar em 3D, isso é, a visão tridimensional como técnica de pesquisa, não existe como uma ação específica, mas como uma atitude diante do observado, um conjunto de medidas, uma sintonia imersiva que permite ao pesquisador ser envolvido e capturado pela emoção de observar e descobrir diferentes nuances e dimensóes do vivido; ao mesmo tempo em que se observa, descreve, se percebe incluso no processo que observa e interpreta. Assim, quanto mais rica for a observação, mais acentuados e contundentes forem os detalhes, mais profunda poderá ser a compreensão da cena observada. $\mathrm{O}$ envolvimento e a conexão com os sujeitos dão profundidade ao observado, descrito, capturado.

É importante considerar que, se um olhar bidimensional na pesquisa se caracterizaria por processos mais descritivos daquilo que ocorre com os sujeitos no espaço, onde há um eu e um ele, um sujeito e um espaço, com toda a dimensão binária da cultura, no olhar em $3 D$ o esforço metodológico seria de observar a dinâmica relacional das açóes corpóreas e dos movimentos afetivos, como mais um elemento a ser considerado e não negado, subsumido.

No desenvolvimento de pesquisas com as crianças bem pequenas, que ainda se comunicam pouco pela oralidade, o olhar em $3 D$ poderia dar ênfase, 
no processo de geração dos dados, à dimensão afetiva presente na comunicação corporal entre as crianças e o pesquisador. A dimensão corpórea, a corporeidade como um elemento efetivo nos processos interativos manifestos nos gestos, trocas de olhares, movimentaçóes, no diálogo e narrativas não centradas na palavra. Enredos marcados pela escuta sensível, uma conexáo que exige uma entrega completa de corpo inteiro, sem reservas do pesquisador na relação com as crianças.

A dimensão afetiva foi historicamente combatida pelas abordagens positivistas de pesquisa, uma vez que para Descartes (2003, p. 37) "os sentidos nossos sentidos às vezes nos enganam"; na perspectiva do olhar em $3 D$, pelo contrário, os sentidos foram um elemento que conectou, afinou a comunicação e ajudou no estabelecimento de vínculos. Como afirma Merleau-Ponty (1996), percebemos com todos os sentidos juntos, não vemos apenas com os olhos, ouvimos com os ouvidos, mas sim com o corpo inteiro.

Enquanto tenho um corpo e através dele ajo no mundo, para mim o espaço e o tempo não são uma soma de pontos justapostos, nem tampouco uma infinidade de relaçôes das quais minha consciência operaria a síntese e em que ela implicaria meu corpo, não estou no espaço e no tempo, não penso o espaço e o tempo, eu sou no espaço e no tempo, meu corpo aplica-se a eles e os abarca. (MERLEAUPONTY, 1996, p. 195).

A abordagem fenomenológica de Merleau-Ponty, que tem na corporeidade um elemento fundante da percepção e da conexão com o mundo, foi neste estudo um elemento teórico presente na compreensão e interpretação densa.

Dessa forma, com o intuito de abordar os dois aspectos relevantes no processo de produção de pesquisa sinalizados no início do texto, estar lá e escrever aqui, desdobramos nossa discussão em cinco tópicos: (1) a inserção no campo de pesquisa e a quebra de resistências; (2) o exercício da atitude de escuta e reorganização dos objetivos da pesquisa; (3) a observação das rotinas e o encontro com o inesperado; (4) a saída do campo: a escrita como uma experiência de teorizar o vivido; e (5) a experiência de partilha sobre os que as crianças nos ensinaram.

\subsection{A inserção no campo de pesquisa: a quebra de resistências}

A inserção no campo de pesquisa nos confrontou com o desafio de ver e perceber as crianças, o que nos possibilitou exercitar as técnicas e os instrumentos de pesquisa propostos no projeto inicial. No entanto, ao operarmos com os recursos 
metodológicos da etnografia, primeiramente nos deparamos com o desafio de quebrar as resistências e deixar de ser um estranho ${ }^{8}$, um invasor, alguém que altera a dinâmica já estabelecida entre as crianças e os adultos. Para Bauman (2001, p. 111):

Os estranhos se encontram numa maneira adequada a estranhos. Um encontro de estranhos é diferente de encontros de parentes amigos, ou conhecido. No encontro de estranhos náo há uma retomada a partir do ponto em que o último encontro acabou, nem troca de informaçóes sobre as tentativas, atribuiçóes ou alegrias desse intervalo, nem lembranças compartilhadas: nada em que se apoiar ou que sirva de guia para o presente encontro. $\mathrm{O}$ encontro de estranhos é um evento sem futuro (o esperado é que não tenha futuro), uma história para "não ser continuada", uma oportunidade única a ser consumada enquanto dure esse ato.

Diante desse desafio, o pesquisador precisa assumir uma postura de humildade, desenvolver uma atitude de escuta sensível (BARBIER, 2007). É preciso esperar o tempo de abertura do outro, permeado por momentos de recuo e momentos de uma observação mais participativa e comunicativa.

Esse processo implica reconfigurar nossa postura de pesquisador para conquistar os sujeitos envolvidos, uma vez que a etnografia pressupóe um longo tempo de estadia no campo de investigação. Na pesquisa mencionada neste texto, o tempo de presença foi de nove meses. A permanência no campo possibilitou-nos desenvolver o olhar em $3 D$, um exercício que buscou ampliar a visão, a capacidade de observar as dinâmicas em perspectiva; ver não apenas com os olhos, mas estabelecer relaçáo corporal, de proximidade, de toque, manifestada em açóes de cooperação, de suporte às solicitaçóes tanto das crianças, como dos adultos. $\mathrm{Ou}$ seja, observar por diferentes ângulos, capturar as cenas por instrumentos distintos - pela lente da câmera, na emoção da narrativa no diário de campo.

Outro elemento fundamental na etapa de inserção no campo de pesquisa foi a atitude de escuta, respeitando o tempo de abertura do outro. Atitude que nos permitiu refletir e retomar os objetivos propostos, o que de fato queríamos observar e compreender. Qual era o nosso foco de pesquisa? O olhar em 3D para as manifestaçóes das crianças e dos adultos e a atitude reflexiva nos confrontavam com os conceitos e

8 Bauman (2001, p. 111) diz que "uma cidade é um assentamento humano em que os estranhos têm chance de se encontrar." Isso significa, para Bauman, que estranhos têm chance de se encontrar em sua condição de estranhos, saindo como estranhos do encontro casual que termina de forma tão abrupta quanto começou. 
princípios que constituíam a nossa compreensão acerca da experiência de pesquisa e de como poderíamos capturar as cenas e gerar os dados. A descrição no diário de campo foi utilizada sempre depois de sairmos da escola, constituindo-se como um tempo narrativo e reflexivo de todas as cenas observadas. A tessitura de comentários e questionamentos foi orientadora das observaçóes na etapa seguinte. $\mathrm{O}$ diário de campo foi um instrumento importante de rememoração do vivido em cada dia de observação.

Para Merleau-Ponty (1994), compreender os conceitos não diz respeito a uma filosofia idealista mas existencial, pois implica em refletir o que eles significam para nós, em nossas vidas e no mundo. Assim, captar fenomenologicamente a essência da percepção ${ }^{9}$ é compreender como a percepção efetivamente funciona em nossas relaçóes com o mundo circundante e com as outras pessoas. Nesse sentido, a essência não pode ser separada da existência, bem como a compreensão conceitual separada da compreensão do mundo ao qual se refere.

Essa proximidade, por meio de uma relação cada vez mais próxima, com cumplicidade e sintonia, ampliou as possibilidades de captura das complexidades das dinâmicas, nas interaçóes entre criança-criança, professor-criança, no sentido de perceber os processos vividos pela criança nos momentos observados, nas suas curiosidades e investigaçóes, nas suas iniciativas de participação, nas brincadeiras, no banho, nas trocas, nas refeiçóes, no sono, no choro e nas risadas. Cada vez mais havia o convite para a pesquisadora se envolver nas atividades. Para Geertz (2008, p. 20), "A prática da etnografia é estabelecer relações, selecionar informantes, transcrever textos, levantar genealogias, mapear campos, manter um diário de campo."

Essa etapa da pesquisa nos permitiu compreender o quanto a inserção no campo de pesquisa é marcada pelo exercício de aproximação, pelo estabelecimento de vínculos e afetos, por ajustes de procedimentos do pesquisador para com o grupo e do grupo para com o pesquisador. Uma vez que o pesquisador não é neutro, ele é parte das relaçóes, suas açóes interferem nas dinâmicas dos sujeitos observados. Exige, portanto, do pesquisador a disposição para perceber pela escuta sensível o quanto a sua presença afeta e altera as dinâmicas e igualmente se permitir ser afetado, ou seja, acolher o afeto dos sujeitos pesquisados.

9 Chauí, a partir de Merleau-Ponty, conceitua a percepção como um modo de nossa consciência relacionarse com o mundo exterior pela mediação do nosso corpo. "A percepção é uma vivência dotada de estrutura: há o ato de perceber (pela consciência) e há o correlato percebido (a coisa externa); a característica principal do percebido é a de oferecer-se por faces, por perfis ou perspectivas, como algo interminável que nossos sentidos nunca podem apanhar de uma só vez e de modo total [...] é uma vivência da consciência, um ato cujo correlato são qualidades percebidas pela mediação do nosso corpo; é um modo de estarmos no mundo e de nos relacionarmos com a presença das coisas diante de nós, é um modo diferente, por exemplo, da vivência imaginativa, da vivência reflexiva." (CHAUÍ, 1995, p. 236). 
Para Passos e Barros (2009), toda pesquisa se constitui num processo de intervençâo e exige do pesquisador um mergulho no plano da experiência, em que o conhecer e o fazer se tornam inseparáveis, impedindo qualquer pretensão à neutralidade. "Conhecer é, portanto, fazer, criar uma realidade de si e do mundo, o que tem consequências políticas. [...] o método, assim, reverte seu sentido, dando primado ao caminho que vai sendo traçado sem determinaçóes ou prescriçoóes de antemão dadas.” (p. 30).

Capturar as interaçóes e se deixar ser capturado pelas dinâmicas são atitudes que precisam se efetivar no processo da pesquisa, como nos indica Geertz (2008, p. 20): "a etnografia é uma descrição densa." O que o etnógrafo enfrenta de fato são as rotinas, uma multiplicidade de estruturas conceptuais complexas, muitas delas sobrepostas ou amarradas umas às outras, que são simultaneamente estranhas, irregulares e inexplicáveis. Primeiramente, o etnógrafo precisa apreendê-las e depois apresentá-las de forma descritiva e consistente. Trata-se de exercício a ser desenvolvido em todos os momentos no seu trabalho de campo, tanto nas açóes rotineiras como nas mais inusitadas, uma vez que:

A etnografia é uma descrição densa. O que o etnógrafo enfrenta de fato é uma multiplicidade de estruturas conceptuais complexas, muitas delas sobrepostas ou amarradas uma as outras, que são simultaneamente estranhas, irregulares e inexplícitas, e que ele tem que, de alguma forma, primeiro apreender e depois apresentar. (GEERTZ, 2008, p. 20).

O instrumento do olhar em $3 D$ permitiu que a mesma cena fosse capturada e interpretada a partir de várias dimensóes; ora a lente ou o olhar focavam numa criança em particular para tentar perceber os movimentos, o corpo em ação e suas narrativas; ora o efeito zoom se voltava para as interaçóes mais coletivas, num movimento do particular para o coletivo e vice-versa. Essa mesma cena capturada pela lente da câmera era posteriormente narrada no diário de campo.

No movimento de captura, o registro em vídeo e as fotografias foram recursos técnicos que permitiram descrever os detalhes e as nuances interativas entre as crianças e delas com a professora, com o intuito de congelar manifestaçóes, para depois narrá-las e descrever como o corpo se torna um recurso na produção e manifestação da linguagem. A terceira dimensão sempre presente é a dimensão da emoção e dos afetos. O que, nessa cena, capturou nossa atenção para que nela focássemos nossa observação?

É importante ressaltar que essa percepção afetiva também estará muito presente no momento de descrever as experiências vividas no campo da pesquisa. 
Essas vivências no processo de adaptação reconfiguraram os objetivos da pesquisa. Para pesquisar com, precisamos estar abertos ao que o outro nos mostra; nesse sentido, os objetivos nunca estáo totalmente definidos, eles se definem na própria dinâmica da pesquisa.

É importante ressaltar que essa percepção afetiva também estará muito presente no momento da compreensão e interpretação das situaçóes observadas, perceber e acolher os saberes do corpo das crianças, os sentidos e primeiras impressóes, uma vez que ela experimenta, vive no corpo suas primeiras impressóes, ela apreende o mundo com seu corpo. Essas vivências no processo de adaptação reconfiguraram os objetivos da pesquisa. Para pesquisar com, precisamos estar abertos ao que o outro nos mostra; nesse sentido, os objetivos nunca estáo totalmente definidos, eles se definem na própria dinâmica da pesquisa ${ }^{10}$.

\subsection{A atitude de escuta e a reorganização dos objetivos da pesquisa}

Como já explicitado, a atitude de escuta foi uma ferramenta importante no processo de aproximação e apreensão do objeto de pesquisa. A escuta sensível se constituiu numa atitude de respeito ao tempo do outro, de espera, de não invasáo do espaço da criança e dos adultos - fundamental na fase da imersão, no processo de constituição de relações de afeto com os sujeitos da pesquisa. Para Barbier, a escuta é uma postura diante dos desafios do campo empírico.

Trata-se de um escutar-ver [...] a escuta sensível apoia-se na empatia. $O$ pesquisador deve saber sentir o universo afetivo, imaginário e cognitivo do outro para "compreender do interior" as atitudes e os comportamentos, o sistema de ideias, de valores, de símbolos e de mitos. [...] A escuta sensível reconhece a aceitação incondicional do outro. Ela não julga, não mede, não compara. Ela compreende sem, entretanto, aderir às opinióes ou se identificar com o outro, com o que é enunciado ou praticado. A escuta sensível afirma a coerência do pesquisador. Este comunica suas emoçôes, seu imaginário, suas perguntas, seus sentimentos

10 Geertz afirma que após o questionamento à visão colonialista, em meados do século XX, a antropologia teve que revisar seus métodos e teorias. Houve uma alteração importante na relação do pesquisador com os seus pesquisados. Segundo o autor, a natureza das relaçôes "entre os que perguntam e olham e os que são perguntados e se tornam objetos do olhar" tornou-se outra (1989, p.58). Talvez nosso olhar colonizador para as crianças necessite também ser revisado. 
profundos. Ele está "presente", quer dizer, consistente. (BARBIER, 2007, p. 94).

A atitude de escuta provocou sensíveis alteraçóes nos objetivos iniciais da pesquisa. À medida que o pesquisador decide ouvir e perceber os sujeitos do campo e eles apresentam outros aspectos a serem observados, abrem-se novas perspectivas, provocam o pensar em outros aspectos presentes nas dinâmicas. Dessa maneira, a pesquisa com as crianças começa a se processar de modo diferente do imaginado, uma vez que os objetivos que tínhamos previamente definidos foram ressignificados ao longo do período de permanência no campo pelas açóes de pesquisa.

Assim, pesquisar com implica perceber e acolher as diversas manifestaçóes dos corpos em movimento das crianças. Essa observação atenta nos permitiu delinear as dinâmicas das crianças nos ambientes e também deslocou nosso olhar para as açóes dos docentes.

As posturas dos professores foram questionadas em alguns momentos. Observamos sua falta de compreensão sobre os processos do desenvolvimento infantil, bem como a manifestação de um modelo de organização didáticopedagógica excessivamente centrada nos adultos, característica marcante da cultura escolar tradicional na qual há um controle sobre as iniciativas das crianças e sua participação efetiva no planejamento e execução das atividades. Mesmo identificando esses elementos no desenvolvimento das açóes cotidianas, foi igualmente possível, nas ações de educação e cuidado, capturar doçura e delicadeza nos gestos, no afago, no atendimento das solicitaçóes das crianças.

\subsection{A observação das rotinas e a captura do inesperado}

A rotina, como categoria pedagógica que organiza as dinâmicas na Educação Infantil, foi amplamente estudada por Batista (1998), Barbosa (2006), Rodrigues (2009) e Martins Filho (2012). Esses estudos buscaram compreender as nuances daquilo que está presente todos os dias - por exemplo, chegada, saída, sono, banho, trocas, refeiçóes, em oposição ao rotineiro, ou que está preso a grades de horários, com atividades sequenciadas previamente definidas - recepção das crianças das $7 \mathrm{~h}$ às $7 \mathrm{~h} 30$, lanche das $7 \mathrm{~h} 30$ às $8 \mathrm{~h} 00$ e assim sucessivamente; um é $\mathrm{o}$ quotidiano e o outro é a rotina.

No entanto, a rotina pode ser entendida de modo mais dinâmico, envolvendo também o inesperado, o que não acontece sempre da mesma maneira. Barbosa (2006) identifica nas rotinas pedagógicas quatro elementos constitutivos: a) a organização do ambiente; b) o uso do tempo; (c) a seleção e as propostas de atividades; (d) a seleção 
e a oferta de materiais. Segundo a autora, esses elementos definem modos de pensar, prescrever e padronizar as rotinas. Para Barbosa (2006, p. 201):

A rotina é compreendida como uma categoria pedagógica da educação infantil que opera como a estrutura básica organizadora da vida coletiva diária [...]. Fazem parte das rotinas todas as atividades que são recorrentes ou reiterativas na vida coletiva, mas que, nem por isso, precisam ser repetitivas, isto é, feitas da mesma forma todos os dias.

$\mathrm{Na}$ escola pesquisada, apesar de não haver uma grade de atividades preestabelecidas, havia uma sequência na qual as dinâmicas se repetiam. Alguns exemplos são a acolhida das crianças, com um horário definido de chegada, as refeições sempre no mesmo horário, o banho após brincar no parque de areia, o sono coletivo após o almoço.

Nessas atividades, consideradas como rotina, havia um controle maior do professor. Nas brincadeiras livres no parque ou internamente na sala, ou entre essas rotinas, como esperar que o almoço ficasse pronto, havia mais liberdade para as inovaçóes das crianças. Nesses momentos, capturamos cenas inusitadas. Esses momentos foram ricos de observação das crianças, nos quais o espírito investigativo e criativo mais se evidenciava, e as ações do mover-se em liberdade (PIKLER, 2010) se constituíam em possibilidades de aprendizagens, criação e combinaçóes de brincadeiras. É o que podemos observar nesta cena:

Os brinquedos estavam disponíveis no fundo da sala em três caixas de papeláo. A professora estava ocupada organizando um material para apresentação na reunião dos pais. Orientados diretamente pela professora, as crianças elaboravam uma pintura de um painel; nesse momento, a professora intervinha diretamente nas ações das crianças, orientando como deveriam proceder. As nossas observaçóes se dividiam entre o que acontecia com a elaboração do painel e as brincadeiras das demais crianças espalhadas pela sala. Deparo-me com uma cena interessante. Dois meninos brincavam de cortar o cabelo. O primeiro senta na cadeira, coloca a cabeça para trás. O outro pega um pedaço de TNT (tecido náo tecido) e coloca sobre ele, como se estivesse no cabelereiro. Amarra o tecido e depois reproduz movimentos que evidenciam a intencionalidade de quem está lavando o cabelo, depois cortando, finaliza o trabalho com um secador. Logo em seguida, fazem o movimento de inversão 
das tarefas. Nesse momento, eles percebem que estão sendo filmados, se afastam um do outro, procurando outros grupos de crianças. (Diário de campo, setembro de 2012).

Nesses momentos, podemos constatar que a criança, num ambiente rico em possibilidades, não precisa que o adulto, a todo o momento, dirija e controle seus processos de aprendizagem. As crianças demonstraram muitas iniciativas de explorar os ambientes e objetos, bem como as materialidades no seu entorno.

\subsection{A saída do campo: a escrita como uma experiência de teorizar o vivido}

O outro aspecto da pesquisa importante a ser discutido é o processo de distanciamento após a vivência no campo de pesquisa. Nessa etapa, há uma imbricação profunda entre método e teoria. A experiência de escrita se constitui, portanto, num processo de açáo reflexiva sobre o vivido, com intuito de descrever e interpretar as dinâmicas observadas, compilar situaçóes e ampliar a compreensáo do vivido no campo de pesquisa. Assim, nasce também o desejo de compartilhar as nossas experiências de aprendizagem vividas com as crianças.

Nessa perspectiva, a ação de escrita nos coloca diante do desafio do pensamento inovador de abertura e exercício de pensar e elaborar conceitos e ideias nunca pensadas.

Necessitamos nos reeducar para fazer do escrever um ato inaugural; não apenas transcrição do que tínhamos em mente, do que já foi pensado ou dito, mas inauguraçáo do próprio pensar. (MARQUES, 1997, p. 13).

De acordo com Larrosa (2002), experiência é algo singular, que nos passa; não apenas acontece, nos toca. $\mathrm{O}$ que nos passa se constitui tanto como uma iniciação nos mistérios do objeto em análise, como um elemento de transformação de significação do pensar. Ainda em conformidade com o autor:

A experiência não é o que acontece, mas o que nos acontece, duas pessoas, ainda que enfrentem o mesmo acontecimento, não fazem a mesma experiência. $\mathrm{O}$ acontecimento é comum, mas a experiência é para cada qual sua, singular e de alguma maneira impossível de ser repetida. $\mathrm{O}$ saber da experiência é um saber que não pode separar-se do indivíduo concreto em quem encarna. (LARROSA, 2002, p. 27). 
A escrita é, para quem escreve, algo singular, atravessa e modifica o sujeito. Para Merleau-Ponty, a experiência pode ser entendida como uma forma de comunicarse com mundo: "[...] ser uma consciência, ou, antes ser uma experiência, é comunicar interiormente com o mundo [...] uma primeira abertura às coisas sem a qual não haveria pensamento objetivo." (MERLEAU-PONTY,1996, p. 142).

O conceito de experiência em Merleau-Ponty é analisado por Chauí (2002). Para a autora, o conceito de experiência desenvolvido pelo filósofo pode ser entendido como um processo de iniciação aos mistérios do mundo.

A experiência já não pode ser o que era para o empirismo, isto é, passividade receptiva e resposta a estímulos sensoriais externos, mosaico de sensaçôes que se associam mecanicamente para formar percepçóes, imagens e ideias; nem o que era para o intelectualismo, isto é, atividade de inspeçáo intelectual do mundo. Percebida, doravante como nosso modo de ser e existir no mundo, a experiência será aquilo que sempre foi: uma iniciação aos mistérios do mundo. É à experiência que nos dirigimos para nos abra ao que não é nós. (CHAUÍ, 2002, p. 161).

A partir desse argumento, podemos defender que o ato de escrever e descrever as situaçóes vividas passa a ser um tipo de experiência que nos abre aos mistérios do mundo, um rico exercício de pensamento; não uma mera transcrição do vivido, mas algo pensado e refletido. Nesse sentido, na ação de escrever, o pensamento inovador é construído, toma forma e constitui-se numa análise sobre o percebido. Na mesma esteira de raciocínio, Chauí sinaliza que o autor não convida o leitor para:

Reencontrar o que já sabia, mas toca nas significaçôes existentes para torná-las destoantes, estranhas, e para conquistar, por virtude desta estranheza, uma nova harmonia que se aposse do leitor, fazendo-o crer que existira desde sempre e que sempre pertencera. Escrever é essa astúcia que priva a linguagem instituída de centro e de equilíbrio, reordena ou reorganiza os signos e o sentido e ensina tanto ao escritor como ao leitor o que sem ela não poderiam dizer em pensar, pois a palavra náo sucede nem antecede o pensamento porque é sua contemporânea. (CHAUÍ, 2002, p. 19).

Quem escreve é desafiado a escrever como quem busca desvendar os sentidos do mundo - uma experiência original. Chauí, apoiada em Merleau-Ponty, afirma 
que o que torna possível a experiência é a existência de uma falta ou de uma lacuna a serem preenchidas:

[...] sentidas pelo sujeito como intenção de significar alguma coisa muito precisa e determinada, que faz do trabalho para realizar a intenção terminada, que faz do trabalho para realizar a intenção significativa o próprio caminho para preencher seu vazio e determinar sua indeterminação, levando à expressão o que ainda e nunca havia sido expresso. Há uma intenção de significar que é, simultaneamente, um vazio a ser preenchido e um vazio determinado que solicita o querer-poder do agente, suscitando sua açáo significadora a partir do que se encontra disponível na cultura como falta e excesso que exigem o surgimento de um sentido novo. (CHAUÍ, 2002, p. 153).

O ato de escrita e da tessitura da análise dos dados é criativo e nos impulsiona ao que não somos. Trata-se de um desafio que nos lança ao novo, ao diferente, aos mistérios dos pensamentos ainda não pensados, uma aventura, um exercício de pensar que nos proporciona novas aprendizagens, novas perspectivas sobre fenômeno estudado. As leituras anteriores ao momento de ingresso no campo já não bastam, somos chamados pelas novas palavras que nos penetram pelo olhar, pelas vozes e pelas perguntas que as situaçôes vividas trazem à nossa mente.

Dessa forma, a escrita pode ser entendida como um ato de compreensão, uma busca, uma aproximaçáo aos desafios do tema preferencialmente tratado numa obra ou num texto. Essa ação exige do escritor uma capacidade ampliada, que vai além das leituras e do domínio dos conceitos básicos. Exige também do escritor a utilização apropriada dos recursos da linguagem, para que essa experiência possa ser partilhada de forma compreensivelmente comunicável. Logo, tanto o estar com as crianças como o escrever e teorizar o vivido são um ato inaugural: só escrevendo se escreve. É pela experiência de escrita, no processo de análise, que ressignificamos o vivido.

Importa o fato de que, ao que, ao escrever, estou sob a mirada de muitas leituras. Acho-me numa interlocuçáo de muitas vozes que me agitam, conduzem, animam, perturbam. É isso que faz de me escrever uma interlocução de muitas vozes, uma amplificação de perspectivas, abertura de novos horizontes, construção de saberes. (MARQUES, 1997, p. 26). 
Essa é uma dimensão da experiência de escrita que não se reduz ao ato mecânico, mas uma ação que exige do escritor a entrega ao processo. Trata-se de uma experiência que se constrói no fazer e que provoca tanto no escritor como no leitor outros entendimentos acerca do tema desenvolvido; é um fazer que nos retira do lugar onde estamos, propiciando outras perspectivas para compreender e pensar os problemas do nosso tempo.

\subsection{A experiência de partilha: o que as crianças nos ensinaram}

Por meio da escrita, podemos compartilhar os nossos achados com as crianças. Elas nos ensinaram que as novas aprendizagens são uma grande aventura de descoberta; elas aprendem e compreendem fazendo, experimentando uma, duas, três vezes até conseguir. Elas vão do ato ao pensamento, como explicitou Wallon (2008), da ação para a elaboração conceitual.

A observação muitas vezes indicou que os adultos desconsideravam esses processos nas crianças e esperavam que ouvissem passivamente as instruçóes, para depois executar, seguindo as orientaçóes determinadas, muitas vezes, sem a possibilidade de efetuar inovaçóes.

$\mathrm{Na}$ cena narrada a seguir, a professora planejava construir um painel para expor na feira de visitação para os pais. Primeiramente, a professora recortou uma folha de papel de cerca de 1,5 por 3,0 metros e fixou-a na parede. Ela entáo solicitou que todas as crianças se sentassem, pois iria explicar como seria feito o painel.

Depois das crianças serem dispostas sentadas num círculo, a professora explica que irão construir um painel juntas. Que cada criança poderá ajudar a fazer o painel que será exposto à visitação dos pais, por isso, as crianças deveriam caprichar bastante. Ela coloca tinta em pratos de plástico, cores diferentes em cada prato, azul, marrom, amarelo, vermelho, branco. As crianças deveriam ficar sentadas, observando e esperando a sua vez de pintar o painel. As duas ajudantes da professora, neste dia, exerciam funçóes diferentes: enquanto uma passava a tinta na mão da criança com o pincel, a outra estava sentada com as crianças, observando-as e acalmando-as, para que elas pacientemente esperassem chegar a sua vez. No momento em que a criança iria dar a sua contribuição à feitura o painel, ela poderia escolher a cor que sua máo seria pintada e onde queria que fosse deixada a sua marca. A professora segurava a máo da 
criança cheia de tinta, fazia marcas das mãos no formato de árvores, flores, conforme ela indicava. Essa ação sucessiva foi gradativamente ganhando o formato a uma paisagem. (Diário de campo, outubro de 2012).

Essa cena evidencia um tipo de participação que limita a criatividade e a ação inovadora da criança, uma vez que o ato de criação estava centrado na professora, que de fato tinha o controle dos processos. A todo o momento, as crianças buscavam um papel mais ativo e enviavam sinais sobre o quanto elas queriam participar ativamente da feitura do painel, com seus corpos em ação, manipulando as tintas, experimentando as cores e traços. Para as crianças, não existe limite na aventura de experimentar sensaçóes novas. Nesse sentido, os adultos devem oferecer ambientes e oportunizar vivências, mas são as crianças que vivem a experiência.

As crianças nos ensinaram que é necessária uma acolhida às suas iniciativas, com ambientes seguros e possibilidades de vivenciar situaçóes diferentes. As crianças precisam de ambientes seguros para que possam experimentar atividades diferentes; num planejamento diversificado e criativo, elas querem participar ativamente de todo o processo. A criança sabe o que pode com seu corpo e suas iniciativas são indicativos de sua potência pelo conhecer.

A experiência com as crianças nos ensinou que a valorização da participação delas não significa diminuição da autoridade e do poder do adulto. As crianças têm facilidade em compartilhar, e desde muito pequenas aprendem que é melhor brincar em conjunto do que sozinhas. O que os adultos precisam compreender é que a ação pedagógica deve ser uma ação de partilha de saberes e de decisóes, de como e quando realizar as tarefas. As crianças dizem com suas açóes: "queremos participar".

Os relatos de pesquisa nos confrontaram com a nossa própria condição de adultos, de como percebemos as crianças e sua capacidade de compreender o mundo. Elas nos ensinaram com ousadia sobre o desafio cotidiano de superação, de querer sempre experimentar o mundo, as novas possibilidades de seus corpos e relaçóes, repetir quantas vezes forem necessárias para incorporar, para superar, para modificar as aprendizagens. As crianças nos dizem com seus corpos em movimento que é muito bom experimentar as situaçóes novas e retomar as antigas.

Esse tipo de escrita pode ser caracterizado como uma escrita-experiência, ou algo que nos passa. Seria possível viver essa experiência e continuar sendo a mesma pessoa? A questão a ser pensada é a possibilidade de sermos transformados pela experiência de pesquisa, bem como a necessidade e a disposição de quem, ao viver a experiência de pesquisa, se permita ser transformado por ela. Esse é um 
tipo de experiência que nos deixa marcas, que provoca em nós uma mudança de perspectiva.

Partindo do pressuposto de que a experiência da escrita nos transforma, podemos igualmente dizer que o ato de escrever apresenta também uma dimensão de partilha do pensamento, um processo de abertura e de iniciação que não se vive só, como a produção deste texto. Ele se constituiu como uma produção inédita, que traz a narrativa de uma vivência que exigiu um rico exercício de pensamento e leituras, com o confronto de argumentos.

O momento de escrita e de teorização do vivido é um convite aos leitores a uma reflexão em torno da temática. Portanto, trata-se de uma escrita-experiência, ou seja, uma escrita que teoriza o vivido. Não se constitui num texto fechado, concluído, acabado, mas sim num texto aberto, um convite para pensar em conjunto. Dessa forma, o texto sempre sinaliza os caminhos percorridos, fala das nossas escolhas e das nossas leituras e filiações teóricas. Além disso, ele apresenta os questionamentos produzidos, mas numa perspectiva de abertura aos mistérios da temática de estudo proposta.

Nesta outra cena observada numa turma de crianças de 2 a 3 anos, a professora estava desenvolvendo com as crianças o conhecimento de si e a nomeação das partes do corpo.

A professora recortou pedaços de papel pardo do tamanho das crianças, e com o pincel atômico contornou cada criança. Depois de contornado o formato do corpo da criança, as crianças deveriam desenhar, as partes do seu corpo. Depois de concluída a tarefa, a professora escreveu o nome de cada criança na folha de papel e fixou na parede. No final do dia, quando as mães vieram buscar as crianças, um menino chama a máe, a segura pelo braço e a leva diante do seu desenho e diz: "olha mãe eu aqui". (Diário de campo, setembro de 2012).

Nessa cena, é possível perceber uma participação mais efetiva da criança, com liberdade de criação e ação autônoma para produzir as suas impressôes dela mesma. Essa experiência foi tão significativa que a criança quis compartilhá-la com a mãe e expressar os conhecimentos apreendidos na escola.

O desejo de compartilhar as aprendizagens é inerente ao ser humano. Nessa cena, a criança compartilhou com a mãe, e nós, pela escrita, podemos compartilhar as novas aprendizagens, bem como instigar e provocar os leitores a outras formas de pensar, a outros entendimentos. Portanto, esses momentos de escrita se constituem em profundos espaços de liberdade de pensamento e 
transformação de quem escreve, que, ao escrever, rememora toda a experiência vivida, significando-a em outro patamar. Nesse sentido, recorremos mais uma vez a Marques, que fala da imprescindível ação de escrever.

Escrever é preciso, para encontrar-se a si mesmo sendo mais forte do que se é, para a longa e tortuosa busca do outro de um desejo mais paciente. Importa em duplo desconhecimento: o do que somos e podemos e o de outrem que misterioso os aguarda. Trabalhando pela dúvida inaugural da criação, o escrevente busca achar-se, descobrir-se para além das circunstâncias imediatas. (MARQUES, 1997, p. 43).

Diríamos que pesquisar é preciso, pois sem a pesquisa não teríamos o que escrever. É fundamental pesquisar com as crianças, para aprender com elas e sobre elas.

\section{Considerações finais}

Este texto propôs uma reflexão sobre dois momentos significativos que integram a ação de pesquisar com as crianças. $O$ primeiro deles é o rico momento de estar com as crianças e ser desafiado a apreender os sentidos de suas açóes. $\mathrm{O}$ segundo momento envolve a ação de teorizar o vivido, de explicitar e evidenciar o que foi aprendido - um momento de partilha e de contribuição ao debate.

Este texto propôs uma reflexáo sobre dois momentos significativos que integram a ação de pesquisar com as crianças. O primeiro deles é o rico momento de estar com as crianças e ser desafiado a apreender os sentidos de suas açóes. O segundo momento envolve a ação de teorizar o vivido, de explicitar e evidenciar o que foi aprendido - um momento de partilha e de contribuiçáo ao debate por meio da escrita.

Pesquisar é compreender um dado objeto de estudo, ir ao encontro do que não se sabe. Assim, num dado momento da pesquisa, foi necessário nos desapegarmos de nossas hipóteses e nos colocarmos numa atitude de abertura e diálogo, como um mergulho de corpo inteiro no campo. Estar com as crianças implica em estar aberta ao que elas queriam nos dizer com seus corpos, movimentos, olhares. Uma atitude de escuta. Pesquisar com as crianças sugere a construção de instrumentos metodológicos que nos ajudem a visibilizar as suas percepçóes sobre o mundo.

$\mathrm{Na}$ experiência de escrita, é preciso nos deixar envolver tanto pelo processo de rememorar a experiência vivida no campo empírico como no processo de análise e interpretação do vivido. Evidencia-se que a produção da escrita envolve certa ruptura com a barreira da tela em branco e o início de uma escrita que 
contenha a apropriação de outras compreensôes, a ampliação de conceitos já assimilados, bem como a incorporação de outros nós que emerjam das relaçóes que se estabeleceram nos processos investigativos. Esse é um momento em que compartilhamos com nossos leitores a experiência intensa da pesquisa e nossos encontros com as crianças e com nossos interlocutores teóricos.

Essa experiência não poderia deixar de nos modificar, atravessar e impactar nossas formas de pensar o mundo. A experiência é algo singular, que nos passa e nos atravessa, uma ação de singularidade; é um ato inaugural, que nos impulsiona a novas experiências de escrita, novos textos, outros encontros.

As crianças nos ensinaram que o movimento de aprender é sempre um processo de iniciação aos mistérios do mundo. Em nossa experiência de pesquisar com as crianças, o grande desafio foi o de decifrar seus movimentos, suas açóes, descobertas e aprendizagens, o que poderíamos denominar de dimensão corpórea das aprendizagens das crianças. Os dois momentos aqui descritos se complementam na ação de pesquisar com crianças, estar com elas, escrever, teorizar o vivido, compartilhar sobre o que elas nos ensinaram. É uma aprendizagem que nunca termina, mas nos instiga a novas aventuras de pesquisa.

\section{Referências}

BARBIER, Rene. A pesquisa açáo. Brasília: Líber livro, 2007.

BARBOSA, Carmen Silveira. Por amor e por força, rotinas na educaçáo infantil. Porto Alegre: Artmed, 2006.

BATISTA, Rosa. A Rotina no dia-a-dia da creche: entre o proposto e o vivido. Dissertação (Mestrado em Educação) - Universidade Federal de Santa Catarina, Florianópolis, 1998.

BAUMAN, Zygmunt. Modernidade liquida. Rio de Janeiro: Zahar, 2001.

BEBER. Irene Carrillo Romero. As experiências do corpo em movimento das crianças pequenas: reflexōes para a pedagogia da Infância. Tese (Doutorado) Programa de Pós-Graduação em Educação- UFRGS, 2014.

COHN, Clarice. Antropologia da criança. Rio de Janeiro: Zahar, 2005.

CARDOSO, Roberto O Trabalho do Antropólogo: olhar, ouvir, escrever. Disponível em: <www.revistas.usp.br/ra/article/viewFile/111579/109656>

CHAUÍ, Marilena. Experiência do pensamento. São Paulo: Martins Fontes, 2002. 
DESCARTES, René. O discurso sobre o método. São Paulo: Martins Fontes, 2003. GEERTZ, Clifford. A interpretaçáo das culturas. Rio de Janeiro: LTC, 2008. GEERTZ, Clifford. Estar lá, escrever aqui. Disponível em: <http://www2.fct. unesp.br/docentes/geo/necio_turra/PPGG\%20\%20PESQUISA\%20QUALI\%20 PARA\%20GEOGRAFIA/Estar\%201\%E1,\%20escrever\%20aqui.pdfs

LÉVI-STRAUSS, Claude. Olhar escutar ler. São Paulo: Companhia das Letras, 1977.

LOPES DA SILVA, Aracy; NUNES, Angela; MACEDO, Ana Vera Lopes da Silva (Org.) Crianças indígenas: ensaios antropológicos. São Paulo: Global, 2002.

MARQUES, Mário Osório. Escrever é preciso: o princípio da pesquisa. Ijuí: Editora Unijuí, 1997.

MERLEAU-PONTY. Fenomenologia da percepçáo. Martins Fontes, 1996. . Conversas-1948. São Paulo: Martins Fontes, 2004. . Psicologia e pedagogia da criança. São Paulo: Martins Fontes, 2006.

LARROSA, Jorge. Notas sobre a experiência e o saber de experiência. Revista Brasileira de Educação, p. 20-28, jan./fev./mar./abr. 2002.

PASSOS, Eduardo; KRASTRUP, Virgínia; ESCÓSSIA, Liliana (Org.). Pistas do método da cartografia: pesquisa-intervenção e produção da subjetividade. Porto Alegre: Sulina, 2009.

PIKLER, Emmi. Mover se en Libertad: desarrollo de la motricidad global. Madrid: Narcea S. A. Ediciones, 2010.

WALLON, Henri. Do ato ao pensamento. Petrópolis: Vozes, 2008.

WWW.TECMUNDO.com.br/video/2469-como-funciona-a-tecnologia-3d-.htm. 



\section{Educação, Poder e Cidadania}





\title{
Diferenças, alteridade e construção de valores inclusivos \\ Differences, alterity and building of inclusive values
}

\author{
Sandrelena da Silva MONTEIRO'
}

\begin{abstract}
Resumo
Temáticas envolvendo diferenças, alteridade e construção de valores têm ganhado destaque na área da Educação. Tal recorrência em um contexto de grande questionamento aos valores e padróes construídos e mantidos ao longo do tempo nos convida a pensar se, atualmente, as interaçóes sociais têm se dado em um sentido de comunhão entre as diferenças ou de perpetuar processos de exclusão. A partir desta inquietaçáo este texto propóe como objetivo problematizar as relações estabelecidas com as diferenças nas interações sociais e as implicações do processo de desenvolvimento moral na construçáo de relaçóes de alteridade.
\end{abstract}

Palavras-chave: Diferença. Alteridade. Valores inclusivos.
Themes involving differences, alterity and value construction have become prominent in the field of Education. Such recurrence in a context of great questioning of values and standards built and maintained over time leads us to consider whether social interactions have currently been taking place under a sense in the direction of communion among differences or a perpetuation of exclusion processes. Based on these issues, this article tries to problematize the relationships that are established with the differences within social interactions and the implications of the moral development process in the construction of alterity relations.

Keywords: Difference. Alterity. Inclusive Values.

1 Doutora e Mestre em Educaçáo pela Universidade Federal de Juiz de Fora. Pedagoga. Professora adjunta do Departamento de Educaçáo da Universidade Federal de Juiz de Fora. Pesquisas na área do desenvolvimento humano, educação inclusiva e diferenças. E-mail: <sandrelenasilva@yahoo.com.br>.

R. Educ. Públ.

\begin{abstract}
v. 28
\end{abstract}
n. 67 jan./abr. 2019 


\section{Introdução}

Os discursos que dão corpo às reflexôes que envolvem a questão da educação inclusiva têm se constituído a partir de diversos movimentos. Há os que se sustentam nas discussóes políticas, outros nas práticas pedagógicas, que abordam geralmente currículos, planejamento, formação docente, e ainda os que se sustentam nas perspectivas culturais que envolvem o processo educacional. Reconhecendo a importância destes estudos, esta reflexão se coloca em um movimento que perpassa todos os anteriores, uma vez que busca adentrar os valores que os sustentam e mobilizam. Pensar educação inclusiva é, essencialmente, pensar relaçôes humanas; e pensar relaçóes humanas, na contemporaneidade implica, necessariamente, considerar os valores que vêm fundamentando as trocas sociais que aí se estabelecem. É preocupação comum em muitos espaços sociais, especialmente nos espaços escolares, conhecer e problematizar os valores que crianças e adultos priorizam em suas relaçóes.

Em uma pesquisa do tipo estado da arte realizada no período de 2016 a 2017 foi identificado que o tema desenvolvimento moral foi o mais recorrente nos trabalhos garimpados em três espaços de publicação de produções científicas: ANPEd ${ }^{2}$, SCIELO ${ }^{3}$, CAPES $^{4}$ (MONTEIRO, CONSENTINO, EBELING, 2018). A pesquisa não abordava essencialmente a construção de valores inclusivos, no entanto, os dados que dela emergiram construíram desenhos que impulsionaram as problematizaçóes e reflexôes aqui apresentadas. Isso se deu, especialmente quando foram cruzadas as informaçóes de que o desenvolvimento moral era o tema mais abordado, as escolas os espaços privilegiados de pesquisa, e professores e alunos os principais respondentes de questionários, entrevistas, dentre outros; no entanto, não foi encontrada na mesma proporção a preocupação quanto ao entendimento de como se dá a construção de valores e as implicaçóes dos mesmos nas relaçóes interpessoais.

Falar em educação inclusiva ou na mobilização de parte da sociedade brasileira em prol das crianças, adolescentes, jovens e adultos que por algum motivo ficaram à margem do sistema educacional brasileiro implica colocar em pauta os valores que mobilizam essas ações e os que são por elas mobilizados na construçáo de um ideal de uma sociedade mais inclusiva e mais humana.

\footnotetext{
2 Associação Nacional de Pós-Graduação e Pesquisa em Educação - http://www.anped.org.br/

3 Scientific Eletronic Library Online - http://www.scielo.br/scielo.php?script=sci_home\&lng=pt\&nrm=iso

4 Coordenação de Aperfeiçoamento de Pessoal de Nível Superior - http://bancodeteses.capes.gov.br/ banco-teses/\#!/
} 
Educação inclusiva aqui é entendida como aquela que acontece em escolas capazes de "acomodar todas as crianças independente de suas condiçóes físicas, sociais, emocionais, linguísticas ou outras", que incluam "crianças deficientes e superdotadas, crianças de rua e que trabalham, crianças de origem remota ou da populaçáo nômade, crianças pertencentes a minorias linguísticas, étnicas ou culturais e crianças de outros grupos em desvantagem ou marginalizados" (ONU, 1994, p, 03).

Estudar valores e a construção dos mesmos nas relaçóes sociais e individualmente, não é invenção dos dias atuais. Ao longo dos tempos filosofias, psicologias e sociologias se ocuparam desta temática, no entanto, ainda cabe, uma vez mais, a reflexão envolvendo tal temática, especialmente ao se considerar o contexto socio-histórico e cultural que vivemos, em que valores básicos da vida humana, como o ser, se dilui na ânsia do ter, tão bem consubstanciado na ideologia do consumo (MARQUES, MARQUES, 2003).

Taille e Mani (2009) contribuem com essa reflexão quando questionam se, nos dias atuais, há crises de valores ou valores em crise. No entendimento deste autor e desta autora, ao falarmos de crise de valores estamos dizendo de valores morais que correm o risco de extinçáo, que estariam supostamente adoecidos. Já ao falarmos em valores em crise, estamos falando de que há uma permanente mudança de paradigma na qual os valores morais tendem a alteração ao longo dos tempos e das evoluçóes culturais, e não ao desaparecimento ou adoecimento. Tendo em Jean Piaget um de seus principais interlocutores, os autores chegam ao entendimento de que não há falência dos valores morais, mas sim uma mudança na forma como estão sendo vivenciados, em como estão acontecendo nas relaçôes interpessoais.

Corroborando o entendimento destes autores, o movimento reflexivo aqui realizado dá um passo no sentido de buscar conhecer como se constituem valores, como se perpetuam ou se modificam. É com o intuito de propor mais uma variável nesse diálogo com a vida que esse ensaio objetiva problematizar as relaçóes estabelecidas com as diferenças nas interaçóes sociais e as implicaçóes do processo de desenvolvimento moral na construção de relaçóes de alteridade, especialmente no que se refere ao respeito mútuo e à reciprocidade.

Tal proposição nasce do encontro entre a teoria sobre o desenvolvimento moral elaborada por Jean Piaget (PIAGET, 1973, 1994) e as discussôes e açôes atuais, no campo da educação, que tratam da temática diferença e alteridade (MITTLER, 2003; MARQUES, 2012; LARROSA, 2011; MARQUES, FERREIRA, 2011; SKLIAR 2005, 2003). O diálogo entre pesquisadores de diferentes áreas do conhecimento, que se propuseram a estudar as relaçóes humanas e os valores que as sustentam é potente ao pensar a construção de espaços e tempos escolares, que 
possam oportunizar a comunhão (MARQUES, 2012) entre as diferenças rompendo com as barreiras de acesso ao conhecimento (BOOTH, AINSCOW, 2011) que acabam por construir e perpetuar processos de exclusão.

Cooth e Ainscow (2011) entendem a inclusão escolar como uma ação de colocar em prática valores inclusivos. Para estes autores inclusão é "um compromisso com determinados valores que explicam o desejo de superar a exclusão e promover a participação"; sem isso, a "tentativa de inclusão pode representar a simples adesão a uma voga qualquer ou atendimento de instruçóes superiores" (p. 21). A comunhão com as diferenças se constitui, aqui, no principal valor a ser considerado ao pensar as relaçôes humanas, sendo possível uma educação que se faça realmente inclusiva (MARQUES, 2012).

Em busca do entendimento da construção de valores e suas implicaçóes na construção de relaçóes de alteridade, inicialmente apresenta-se um diálogo com as ideias de Jean Piaget sobre o desenvolvimento moral e a construção de valores, para então, a partir daí, buscar uma compreensão de como as relaçóes de coação e cooperação que permeiam ou não as interaçóes humanas podem implicar na construçáo de políticas, culturas e práticas inclusivas, que por sua vez perpassam os movimentos sociais em prol da escolarização de crianças, adolescentes, jovens e adultos.

\section{Desenvolvimento moral e construção de valores inclusivos}

Jean Piaget (1896-1980) náo se dedicou a estudar a questão das diferenças constitutivas da multiplicidade humana, no entanto, seus escritos nos ajudam, especialmente no que se refere ao desenvolvimento moral, não só a pensar a questão das diferenças, mas também da alteridade. Sua presença contribui para o entendimento do desenvolvimento moral e da forma como as crianças lidam com as diferenças (MARQUEZINI, 2013; SCHIPPER, 2015).

Para Piaget (1978) o conhecimento é construído na interação indissociável entre sujeito e objeto, avançando sempre em dupla direção, uma de exteriorização objetivante e uma de interiorização reflexiva, configurando assim uma construção que não se dá nem por determinismo dos fatores externos (sociais ou educativos) nem dos fatores internos (biológicos e hereditários), mas se constitui na interação entre eles. Na dimensão coletiva da relação entre esses fatores, interaçôes significam "condutas se modificando umas às outras, [...] ou formas de 'cooperação', quer dizer operaçóes efetuadas em comum ou em correspondência recíproca” (PIAGET, 1973, p. 22).

O conceito de interação, tal qual explicitado aqui "condutas se modificando umas às outras" é de fundamental importância ao pensar as relações estabelecidas 
com a diferença. Isto porque, ao entender que a criança não nasce com conceitos morais prontos, e que, por outro lado esses não são absorvidos passivamente do meio social, começamos a nos ocupar do entendimento de que os conceitos morais são construídos ao longo do seu desenvolvimento, influenciados tanto por fatores internos quanto externos. Em outras palavras, a forma como a criança irá aprender a viver e conviver com as diferenças será implicada pela relação que ela estabelece com os conceitos morais (dentre eles as regras e valores) que permeiam as relaçóes sociais nas quais se constitui. Em síntese, as relaçóes com as diferenças fazem parte das aprendizagens ao longo do desenvolvimento infantil.

$\mathrm{Na}$ complexidade do processo de desenvolvimento da criança, toda e qualquer aprendizagem é implicada, mas não determinada pelos fatores internos, isto porque as características próprias a cada fase de aprendizagem "são relativas às realidades coletivas 'exteriores' ao indivíduo" (PIAGET, 1973, p. 20). Mas, da mesma forma, não são reguladas puramente pelas interações sociais em si mesmas, uma vez que, para conseguir construir suas operações, a despeito das coaçóes sociais diversas que impóem as noçôes em estado acabado e comunicável, a criança tem a necessidade de repassar todas as etapas, em uma reconstrução intuitiva e depois operatória na relação com às mesmas. Ou seja, ela não assimila de forma passiva um conhecimento que lhe é imposto de forma pronta e acabada, ela "escolhe nas representaçóes ambientais os elementos que consiga assimilar segundo leis precisas de sucessão operatória” (PIAGET, 1973, p. 26).

Neste contexto, ainda que a escola, instituição social privilegiada na construção do conhecimento, busque inculcar na criança o conteúdo das representaçóes coletivas, segundo certo programa cronológico e linguagem própria, e o meio se encarregue de lhe impor os modos usuais de raciocínio, ela não sofre passivamente tais coações da vida social. Ao contrário, a criança "opera uma segregação ativa no que lhe é oferecido e reconstrói à sua maneira assimilando-o" (PIAGET, 1973, p. 21).

Tal explicação nos ajuda a entender que entre as dimensóes do desenvolvimento humano não há uma relação de superposição ou de sucessão hierárquica, mas sim de coordenação e interpenetração. Assim,

[...] não há três naturezas humanas, o homem físico, o homem mental e o homem social, se superpondo ou se sucedendo [...], mas há, por um lado, o organismo, determinado pelas características herdadas, assim como pelos mecanismos ontogenéticos e, por outro lado, o conjunto das condutas humanas, da qual uma comporta, desde o nascimento e em graus diversos, um aspecto mental e um aspecto social (PIAGET, 1973, p. 21) 
Ao buscar entender a interdependência entre os fatores mentais e os sociais, Piaget (1973) retoma o conceito de "mutaçóes intelectuais", proposto por G. Bachelard e A. Koyré. Ao construir este conceito, segundo Piaget (1973), os autores mostram as idas e vindas do espírito humano no caminho da intelecção do real, chegando a comparar seu esforço a uma "mutação do intelecto humano" que possibilitou que as noções científicas que foram penosamente "inventadas" pelos grandes gênios, se tornassem acessíveis ao aprendizado e, até mesmo, fáceis e evidentes para crianças e adolescentes.

Isto quer dizer que uma criança de sete anos, de nove anos ou de doze anos, etc., terá no século XX outras idéias sobre o movimento, a velocidade, o tempo, o espaço, etc., que não tinham crianças da mesma idade no século XVI (quer dizer, antes de Galileu e Descartes), no século X antes de nossa era etc. Isto é evidente, e tal fato evidencia o papel das transmissóes sociais ou educativas. (PIAGET, 1973, p. 27).

De forma análoga, podemos pensar as crianças nos dias atuais (século XXI, ano 2018), frente a todo o avanço tecnológico, que nos permitiu romper com barreiras do tempo e do espaço; as "invençóes" no campo da física quântica e da cibernética, possibilitando construir não apenas outras noçôes na relação com o tempo e o espaço, com o movimento e a velocidade, mas com a própria concepção de ser humano e relaçóes interpessoais. Se considerarmos, o que se refere, por exemplo, à educação, é recente nosso entendimento de que todas as pessoas, independentemente de suas condiçôes físicas, sensoriais, cognitivas, comportamentais, sociais, culturais, afetivas, étnicas, religiosas dentre outras que configuram as múltiplas possibilidades de ser e estar no mundo, têm o mesmo direito à educação: uma educação inclusiva que atenda às suas especificidades, que os conceba como seres integrais. Com certeza essa seria uma fala muito estranha ao próprio Galileu ou Descartes. Mas, houve aqueles que deram os primeiros passos nesse pensamento, aqueles que possibilitaram uma "mutação intelectual" que favoreceu outros entendimentos, outras concepçóes, às quais tivemos acesso por meio das transmissóes sociais e educativas.

Ainda sobre esta ideia de "mutação intelectual", que nos parece ser importante ao entendimento das mudanças que ocorreram e ocorrem no plano da ontogênese, da filogênese, da sociogênese e psicogênese, cabe ouvir um pouco mais o entendimento de Piaget (1973, p. 28):

[...] a 'mutaçáo intelectual' não se manifesta sob a forma pura e simples de substituiçáa das idéias antigas pelas novas: ela intervém, ao contrário, sob a forma de uma aceleração do 
processo psicogenético cujas etapas permanecem relativamente constantes em sua ordem de sucessão, mas que se sucedem mais ou menos rapidamente segundo os meios sociais.

Quanto aos fatores implicados na ocorrência dessas mudanças, Piaget diz que não poderiam ser explicados exclusivamente nem pela maturaçáo nervosa, nem pela transmissão social e nem mesmo pela simples união desses dois processos. Isto porque,

[...] se a transmissão social acelera o desenvolvimento mental individual, é porque entre uma maturação orgânica que fornece potencialidades mentais, mas sem estruturação psicológica feita, e uma transmissão social que fornece elementos e o modelo de uma construção possível, mas sem impor esta última num bloco acabado, há uma construção operatória que traduz em estruturas mentais as potencialidades oferecidas pelo sistema nervoso; mas ela só efetua esta traduçáo em função de interaçóes entre os indivíduos e por conseguinte sob a influência aceleradora ou inibidora dos diferentes modos reais destas interaçôes sociais. Assim, o biológico invariante (enquanto hereditário) se prolonga simultaneamente em mental e social, e é a interdependência desses dois últimos fatores que pode explicar as aceleraçôes ou os atrasos do desenvolvimento segundo os diversos meios coletivos. (PIAGET, 1973, p. 28-29).

Se as interaçôes entre o indivíduo e os objetos materiais causam mudanças tanto em um quanto em outro, não poderia ser diferente nas interaçóes entre os indivíduos, assim, cada interação modificará um sujeito em relação ao outro e a si mesmo: temos aqui um entendimento do princípio da alteridade (LARROSA, 2011, SKLIAR, 2003). É a "irrupção do outro que pode instaurar uma nova e original relação com a mesmidade. Mas não uma relação tranquila, transparente, consistente, nem muito menos incondicional ou empática. A irrupção do outro é uma diferença que difere, que nos difere e que se difere sempre de si mesma" (SKLIAR, 2003, p. 45).

Essas relaçóes não se fazem como uma simples soma de indivíduos ou uma superposição de realidades, mas sim um sistema de interaçóes modificando os indivíduos em suas estruturas. Desta forma, pensar as relaçóes estabelecidas com as diferenças e as implicaçóes do processo de desenvolvimento moral na construção de relaçóes de alteridade, requer pensar as próprias interaçóes sociais e os mecanismos pelos quais elas se efetivam, se mantêm e se modificam. 
Segundo Piaget (1973) um dos elementos que permitem a conservação das coletividades é a existência de uma escala comum de valores e que as trocas que aí tomam lugar tenham benefícios recíprocos. Esta escala de valores é constituída de valores provindos tanto de interesses e gostos individuais quanto de valores coletivos impostos (regras morais e jurídicas): "Toda escala de valores corresponde a uma coletividade de co-valorização constituída pelo conjunto dos indivíduos co-permutadores segundo esta escala" (p. 131). Em seus estudos Piaget faz uma análise das relaçôes de troca envolvendo tanto valores econômicos quanto valores virtuais. À nossa discussão importa o que Piaget denominou de valores virtuais (aprovação, gratidão, reputação, respeito, autoridade, etc) e como estes se fazem presentes nas escalas de valores individuais e coletivas.

A partir das interaçóes sociais e de acordo com o próprio desenvolvimento, cada indivíduo constrói sua própria escala de valor. A escala de valor individual considera a relação entre as finalidades, objetivos, meios para atingi-los, objetos e pessoas pelas quais tem algum interesse, açôes, trabalho e outras formas de "serviço" atual ou virtualmente prestados àqueles com quem se relaciona. É essa escala que permitirá que aconteçam as trocas de valores dentro de uma coletividade.

Quando há uma troca entre dois ou mais indivíduos, de tal forma que haja benefício recíproco, temos uma dupla relaçáo de valorização constituindo empiricamente o que se pode chamar de 'simpatia' (tudo o que um faz satisfaz ao outro mais do que custou ao primeiro). Para que haja essa valorizaçáo recíproca há que se ter uma escala comum de valores, sem a qual, a troca se faz ao acaso ou não é possível. Por outro lado, quando há uma relação de dupla desvalorização (desvalorização recíproca) temos a 'antipatia'. Essa desvalorização de um ou outro, ou de ambos, constitui a ruptura com a escala comum de valores. Náo que todos tenham que concordar com as mesmas opinióes, no entanto, valores essenciais como respeito à dignidade da pessoa humana e liberdade de pensamento são básicos para que haja harmonia em uma sociedade e equilíbrio em uma troca de valores.

Segundo Piaget (1973), o equilíbrio das trocas de valores comporta três condiçóes: a primeira é que os sujeitos "estejam de posse de uma escala comum de valores intelectuais, expressos por meio de símbolos comuns unívocos" (p. 108); a segunda, que haja "igualdade geral dos valores em jogo nas sucessóes, ou seja, conservação" (p. 109); e a terceira, que exista "a atualização possível, em todo o tempo dos valores virtuais" (p. 109), ou seja uma reversibilidade que acarreta a reciprocidade. Estas condiçôes de equilíbrio acarretam a constituição de uma lógica, no entanto, só são possíveis em trocas fundamentadas na cooperação. Isto porque

[...] o equilíbrio não pode ser conseguido quando, por egocentrismo intelectual, os parceiros não conseguissem coordenar seus pontos de vista: falta entáo a primeira 
condição (escala comum de valores) e a terceira (reciprocidade) de onde a impossibilidade de atingir a segunda (conservação). (PIAGET, 1973, p. 109-110).

Ao falar das trocas de valores Piaget irá destacar pelo menos dois tipos: a troca simples e a que denomina de reciprocidade normativa. O que irá diferenciar uma da outra é a operação mental realizada. Na simples troca de valores, temos um sistema simples de percepçáo, uma representação não normativa. No caso da reciprocidade normativa temos um raciocínio, ou seja, um sistema de operaçóes normativas de ordem lógica. Na primeira temos o que Piaget (1973) denominou de troca atual, a qual corresponde a uma percepção imediata dos valores, e é diretamente controlada pelos interessados pessoais, configurando uma reciprocidade vivida ou intuitiva. No caso do equilíbrio normativo, acontece uma troca no tempo, durável, ou seja, sai do quadro de percepção imediata, não permitindo ao interessado um controle direto, requerendo, desta forma, a intervenção de normas estabilizadoras, isto é, de uma reversibilidade operatória, sendo por isso denominada de reciprocidade normativa.

Enquanto a troca simples, que visa uma finalidade utilitária, se efetua do ponto de vista próprio, ou seja, de uma satisfação pessoal, a reciprocidade normativa se constitui em um ato moral, que se coloca no ponto de vista do outro, age para a satisfação do outro, a qual constitui um fim e não mais um meio para se ter um retorno ou resposta. Temos aqui a possibilidade da conservação moral, a qual está baseada na substituiçáo dos pontos de vista, enfim, em reciprocidade desinteressada e reversibilidade. Assim, nos é possível compreender que "o equilíbrio normativo de reciprocidade moral é, pois, atingido, [...] quando um dos parceiros conserva os valores do outro, segundo a escala deste outro" (PIAGET, 1973, p. 142).

Podemos chegar assim ao entendimento de um outro conceito de fundamental importância nesta reflexão, o de respeito mútuo. Primeiramente precisamos entender o que é respeito.

Podemos chamar respeito, o sentimento ligado às valorizaçóes positivas (e ausência de respeito para as valorizaçóes negativas) das pessoas (indivíduos), em oposição à valorização dos objetos ou serviços. Respeitar um homem significa, assim, atribuir-lhe um valor, mas podemos atribuir um valor a uma de suas açóes e a um de seus serviços sem valorizá-lo como indivíduo. Respeitar uma pessoa será, pois, reconhecer sua escala de valores, o que não significa adotá-la por si só, mas atribuir um valor ao ponto de vista desta pessoa. (PIAGET, 1973, p. 145). 
Respeitar uma pessoa não se resume a obedecer às regras por ela impostas, visto que é o respeito pela pessoa que gera as obrigaçóes em relação a ela e não o inverso.

O respeito é a expressão do valor atribuído ao outro, desta forma, conduz à formaçáo de condutas "desinteressadas" que caracterizam as normas morais. Em outras palavras, dizer que uma pessoa $A$ respeita uma pessoa $B$ implica em dizer que em sua conduta em relação a $B$, A se coloca do ponto de vista de $B$ e de sua escala de valores. "A 'substituição recíproca das escalas' ou dos 'meios e dos fins' nada mais é do que a expressão de um respeito mútuo" (PIAGET, 1973, p. 146).

Ao falar da gênese do desenvolvimento psicológico, Piaget $(1994,1973)$ diz que a primeira forma de respeito construída pela criança é o respeito unilateral, que traz em si uma valorização não recíproca na relação com o outro.

Difícil entender a ideia de respeito unilateral quando Piaget usa, por exemplo, a relação entre pais e filhos e diz que essa está em constante desequilíbrio porque as açóes dos pais são muito mais valorizadas pelos filhos que o contrário, isto porque, especialmente nos dias atuais, tem se buscado uma relação com a criança na qual a mesma é respeitada nas suas especificidades. Mas não é a isso que Piaget se referia, em um primeiro momento, mas ao próprio desenvolvimento da criança, que começa por estabelecer com seus pais uma relação pautada em valores especificamente afetivos, não operatórios. Há que considerar que a criança muito pequena ainda não tem condiçóes de realizar operaçóes mentais necessárias à reciprocidade normativa. As consequências imediatas dessa relação se apresentam no fato de a criança, em um primeiro momento, adotar a escala de valores da pessoa respeitada, a partir da qual irá construir a sua própria. Uma segunda consequência é o fato de o respeito ao adulto se traduzir pelo reconhecimento de que ele teria o direito de dar ordens, instruçóes e ser obedecido. Ou seja, a criança se sente na obrigação de se conformar àquilo que lhe está sendo oferecido. No entanto, há que ressaltar que essa obrigação da consciência aparece na criança na medida em que ela respeita aquele que a instrui. Assim, essa obrigaçáo, inicialmente indiferenciada, se tornará "moral" desde que as instruçóes recebidas preencham a condição da satisfação desinteressada, caminhando, finalmente, para a construção do respeito mútuo (PIAGET, 1994, 1973).

Nas relaçóes pautadas no respeito mútuo temos a valorização recíproca dos envolvidos e seu resultado será a reciprocidade normativa. Aqui há um reconhecimento de uma escala comum de valores, ou, em caso de divergência, há um reconhecimento mútuo da legitimidade do ponto de vista do outro. Este respeito ao ponto de vista do outro só é possível graças a valores comuns mais gerais dos quais os valores divergentes aparecem como derivados. "Desde então, não existirão mais entre eles relaçooses de autoridade, obediência de ordens, instruçôes, etc., mas relações de simples acordo mútuo" (PIAGET, 1973, p. 
147). A valorização recíproca adquire um caráter normativo, que torna os valores duráveis, e que não está presente na troca simples.

Buscando entender a relação do respeito com as normas (regras) sociais, temos que "as normas devidas ao respeito unilateral constituem uma moral do dever, e as normas devidas ao respeito mútuo, uma moral da reciprocidade. Essa diferença se deve, pois, unicamente à forma da obrigação ou da norma e não a seu conteúdo" (PIAGET, 1973, p. 148).

Aqui faz-se importante destacar que em relaçóes sociais e especialmente educativas, quando pautadas na coação e não na colaboração, a moral do dever pode impor regras cujo conteúdo foi inicialmente modelado pela moral da reciprocidade. Assim, por exemplo, noções justiça, respeito, afetividade, reciprocidade, que fazem parte do desenvolvimento das crianças e adolescentes, quando são impostas sem serem reconstruídas paulatinamente por esses, configuram-se em obrigação por dever, uma vez que a norma é recebida completamente feita, sendo assim heterônoma. Enquanto que, quando há uma construção por reciprocidade destas noçóes, os sujeitos obrigados pela norma colaboram eles mesmos e de forma autônoma para a sua elaboração (PIAGET, 1973, 1994). Tal imposição culminará por descaracterizar a valorização recíproca e desinteressada do outro, criando campo propício ao nascimento e cristalização de estereótipos, tendo por fim a configuração dos preconceitos e exclusão de toda ordem.

\section{Diferenças e alteridade: provocações}

Voltar o olhar para as relaçóes entre os indivíduos implica em considerar, especialmente, o que se refere aos dois tipos extremos que as configuram: coação e cooperação. Entre um extremo e seu oposto muitas outras formas de relaçóes se estabelecem. No entanto, chama a atenção o fato de que nas diversas coletividades acaba por prevalecer relaçóes de um tipo ou de outro.

Aqui já há o entendimento de que as relaçóes que se sustentam na coação implicam a figura da autoridade e daquele que a ela se submete, constituindo assim uma postura heterônoma, com desejo de homogeneidade diante da vida. Em educação, um dos resultados das relações de coação é o silenciamento:

[...] que se manifesta na postura de alguns professores e professoras detentores do conhecimento, implicando numa relação estabelecida verticalmente com alunos e alunas e até com outros colegas professores e professoras, onde as formas de dominação são utilizadas a todo momento. Os alunos são, por sua vez, muitas vezes passivos, subjugados 
à autoridade dentro da hierarquia normalizada na escola. Mas, ao mesmo tempo, ocorre a dominaçáo por parte de alguns alunos e alunas de outros colegas. As situaçôes de opressão são instauradas, legitimadas e reproduzidas e os sujeitos passam, assim, a refletir a situação de opressão que vivenciam. (MARQUES e FERREIRA, 2011, p. 41).

Por outro lado, quando as relaçôes interpessoais se sustentam na cooperação, implicando a igualdade de direitos, autonomia e reciprocidade entre as pessoas, multiplicidade e diferença fazem-se valores a serem conservados; e então, a possibilidade de uma educação dialógica, viva, "na qual os gestos do professor, da professora, do aluno e da aluna são considerados e respeitados" (MARQUES e FERREIRA, 2011, p. 50). Booth e Ainscow (2011, p. 19) destacam que "quando duas ou mais pessoas estão em diálogo existe uma exploração mútua da opinião de cada uma e prerrogativas baseadas na igualdade, honestidade e confiança. Escutar torna-se mais importante do que falar". Ao falar da educaçáo de pessoas com deficiência, Mittler (2003) aponta que o desafio mais importante seria "o de tornar as crianças e os jovens capazes de falarem por si próprias” (p. 250), de estabelecerem diálogos, e, até mesmo, questionar o sistema, as visóes de suas famílias e dos profissionais que com eles trabalham, o que poderia possibilitar o desenvolvimento de habilidades para exercer escolha e autodeterminação. O diálogo, baseado em valores inclusivos, possibilitaria a superação de barreiras de acesso ao conhecimento. Com certeza, apenas as relaçóes interpessoais cooperativas seriam capazes de oportunizar tal condição dialógica.

Especialmente no que refere aos contextos educativos, Piaget (1973) destaca que a coaçáo transforma o indivíduo muito menos profundamente que a cooperação e que, quando predomina a coação, o que ocorre é que as relaçóes interpessoais são recobertas por uma "fina camada de noçôes comuns, não diferindo, em sua estrutura, das noçóes egocêntricas” (p. 168). Situaçóes semelhantes foram registradas na pesquisa de Schipper (2015) que aponta que formas utilizadas no contexto escolar, no que se refere à educaçáo moral dos alunos pesquisados, ressaltam as práticas de diálogos repreensivos, perda de prêmios e atividades prazerosas quando há comportamentos socialmente negativos e a presença de elogios e prêmios quando o comportamento é positivo. Tais posturas acabam por reforçar as relaçóes de respeito unilateral nas relaçóes entre professor e aluno, dificultando o desenvolvimento autônomo.

Importante destacar que, quando se fala em cooperaçáo no plano das trocas de valores, há uma oposição ao egocentrismo intelectual e moral e também ao laissez-faire. Desta forma, ao falar de 
[...] autonomia, em oposição à anomia e à heteronomia, diz com efeito, atividade disciplinada ou autodisciplinada, a igual distância da inércia ou da atividade forçada. É onde a cooperação implica um sistema de normas, diferindo da livre troca cuja liberdade se torna ilusória pela ausência de tais normas. E, é porque a verdadeira cooperação é tão frágil e tão rara no estado social dividido por interesses e submissóes, assim como a razão permanece tão frágil e táo rara em relação às ilusóes subjetivas e aos pesos das tradiçóes. (PIAGET, 1973, p. 111).

Neste sentido, para quem se relaciona com as regras sociais de forma autônoma, há um autoconhecimento do valor da própria ação, "sob a forma de 'satisfação interior' e cuja 'boa consciência' constituirá uma espécie de autoaprovação” (PIAGET, 1973, p. 144). A troca moral assume assim o caráter de troca interiorizada nas consciências. Quando há a interiorização e entendimento da norma moral, não importa quem é o outro, mas sim a relação que estabeleço com ele. $\mathrm{O}$ valor em jogo nesta troca é o valor máximo de ser humano. Ainda neste contexto cabe ressaltar que, de modo geral,

[...] toda ação ou reação de um indivíduo, avaliado segundo sua escala pessoal, repercute necessariamente sobre outros indivíduos: ela lhe é útil, proveitosa ou indiferente, isto é, marca um crescimento $(+)$ de seus valores (= satisfação), uma diminuição (= prejuízo) ou uma diferença nula. Cada ação provocará, pois, por parte dos outros indivíduos uma ação de volta. Ora, esta pode consistir numa ação material ("valor atual"), tal como uma transferência de objetos em troca do serviço prestado, ou numa ação virtual tal como aprovação ou censura, estímulo para perseverar ou convite a cessar, uma promessa, etc; falaremos então dos "valores virtuais". (PIAGET, 1973, p. 119).

É no campo desta valorização recíproca, do uso dos valores virtuais, seja positiva ou negativa que se inscrevem as relaçóes de alteridade.

Historicamente as diferenças constitutivas dos seres humanos, que fazem cada um de nós uno no múltiplo ou múltiplo em contraposição ao universal, foram silenciadas, negadas (MARQUES, 2012). E, quando se faziam perceber, eram consideradas como desvios a serem corrigidos para o restabelecimento da ordem. Mas, a sociedade, em seu movimento de mudança surgem outras concepçóes, 
outros valores. E, graças particularmente aos movimentos sociais, que buscam dar visibilidade às diferenças, quer seja pela denúncia de práticas de discriminação ou pela reivindicação de igualdade social, vemos a construção de uma outra forma de relação com o outro, na qual a multiplicidade e a diferença ganham contorno de normas jurídicas. Intenta-se o respeito às diferenças.

No entanto, como dito alhures, ainda que uma regra seja composta com conteúdo modelado inicialmente pela moral de reciprocidade, quando imposta pronta e acabada, bastando ser simplesmente "absorvida", sem uma reconstrução interna, por aquele a quem se destina, termina por assumir o caráter de uma obrigação por dever, sem uma internalização consciente da mesma. Tal proposta torna-se frágil, e acaba por configurar o que Marques (2012) nomeia de marcação das diferenças. Assim, parte do princípio que as diferenças são inerentes à vida, no entanto, as relaçóes de alteridade aí estabelecidas ainda sustentam uma visão dicotômica entre o melhor e o pior, o normal e o anormal, o capaz e o incapaz, culminando, na prática, em relaçóes de coação, com um comportamento pautado na heteronomia moral.

Mas, como tudo na vida é movimento, interação, "condutas se modificando umas às outras" (PIAGET, 1978), se pensarmos o princípio da alteridade pautado em relaçóes de reciprocidade e autonomia moral, talvez consigamos alcançar a comunhão (MARQUES, 2012) com as diferenças: aqui "ser diferente não significa mais ser o oposto do normal, mas apenas 'ser diferente", e ter o "múltiplo como necessário, ou ainda, como o único universal possível” (p. 108).

Certamente, tais relaçóes somente serão construídas em uma "situação social de cooperação autônoma, fundamentada sobre a igualdade e a reciprocidade dos parceiros, se liberando simultaneamente da anomia própria ao egocentrismo e da heteronomia própria à coação" (PIAGET, 1973, p. 110), possibilitando, assim, uma reciprocidade moral.

Alcançado tal estado de relações a diferença não será mais algo a ser silenciado, mas entendido como o que constitui quem e como somos. Assim, as diferenças sexuais, de geração, de corpo, de gênero, de língua, de classe social, de etnia, de religiosidade e tantas outras serão apenas diferenças.

E não há, desse modo, alguma coisa que não seja diferença, alguma coisa que possa deixar de ser diferença, alguma coisa que possa ser o contrário, o oposto das diferenças. Seria apropriado dizer que as diferenças podem ser muito melhor compreendidas como experiências de alteridade, um estar sendo múltiplo, intraduzivel e imprevisivel no mundo. Em educação não se trata de melhor caracterizar o que é diversidade e quem a compóe, mas de melhor compreender 
como as diferenças nos constituem como humanos, como somos feitos de diferenças. E não acabar com elas, não para domesticar, senão para mantê-las em seu mais inquietante e perturbador mistério. (SKLIAR, 2005, p. 59).

Marquezini (2013) defende a ideia de que a autonomia moral seria uma forma de enfrentamento do preconceito pois imprime nos julgamentos o respeito mútuo, a cooperaçáo e a equidade, favorecendo, assim, uma outra forma de relação interindividual na qual prevaleçam princípios igualitários e de reciprocidade normativa.

\section{Considerações finais}

Considerando as interfaces já sinalizadas ao longo deste texto, cabe aqui retomar o objetivo proposto, que é o de problematizar as relaçóes estabelecidas com as diferenças nas interaçóes sociais e as implicaçóes do processo de desenvolvimento moral na construção das relaçôes de alteridade, especialmente no que se refere ao respeito mútuo e à reciprocidade normativa. Ao fazer esse movimento, é importante ressaltar que a construção do respeito mútuo está para o desenvolvimento de uma moral autônoma. Desta forma, náo podemos desconsiderar que o desenvolvimento cognitivo sustentado por uma autonomia intelectual também faz parte deste processo, e que é nas interaçóes sociais, pautadas na cooperação, que se dá sua efetivação.

Com esse entendimento já nos é possível compreender que a forma como as crianças lidam com as diferenças, uma vez que não são pré-determinadas geneticamente e nem simplesmente impostas pela coaçáo social, se constroem nas interações sociais por elas vivenciadas, as quais podem ser mantidas ou modificadas ao longo da vida, mas sempre implicada pelas relaçóes sociais estabelecidas.

Finalmente, reafirma-se o entendimento de que as relações sociais não se fazem como uma simples soma de pessoas ou superposição de realidades, mas constituem um complexo processo de interação que propicia a modificação de um sujeito em relação ao outro e a si mesmo. É, ainda, nestas relaçóes sociais que haverá ou não a possibilidade da construção do respeito mútuo e da reciprocidade normativa como valores inclusivos. E, por fim, ressalta-se a comunhão com as diferenças, como valor a ser considerado nas relações sociais, mas também na dimensão individual, considerando, como o fez Mittler (2003, p. 16) que "o maior obstáculo à mudança está dentro de nós mesmos, seja nas nossas atitudes, seja em nossos medos". 


\section{Referências}

BOOTH, Tony, AINSCOW, Mel. Index para a Inclusão: desenvolvendo a aprendizagem e a participação nas escolas. Traduçáo de Mônica Pereira dos Santos, LaPEADE, 3. ed. Rio de Janeiro, 2011.

LARROSA, Jorge. Experiência e alteridade em educação. In: Revista Reflexáo e Açáo, Santa Cruz do Sul, v. 19, n. 2, p. 04-27, jul./dez. 2011. Disponível em: https://online.unisc.br/seer/index.php/reflex/article/view/2444 Acesso em $10 \mathrm{de}$ agosto de 2016.

MARQUES, Luciana Pacheco. Cotidiano escolar e diferença. In: Educaçáo em Foco, Juiz de Fora, v. 17, n. 1, p. 101-117, mar./jun. 2012. Disponível em: http://www.uff.br/revistaedufoco/files/2012/10/Cotidiano-escolar-ediferen\%C3\%A7as.pdf Acesso em 09 de agosto de 2016.

MARQUES, L.P., FERREIRA, A. M. Gestos de silenciamento no/do cotidiano escolar. In: Silêncios e Educaçáo. FERRARI, A., MARQUES, L.P. (Org.). Juiz de Fora: Editora da UFJF, 2011.

MARQUES, C. A. e MARQUES, L. P. Do universal ao múltiplo: os caminhos da inclusão. In: LISITA, Verbena Moreira S.S. e SOUSA, Luciana Freire E. C. P. (Org.). Políticas educacionais, práticas escolares e alternativas de inclusáo escolar. Rio de Janeiro: DP\&A, 2003, p. 223-39.

MARQUEZINI, Cristiane Pereira. Desenvolvimento moral e preconceito: um estudo sobre os juízos de crianças do ensino fundamental de uma escola inclusiva. 2013184 f. Tese (Doutorado em Educaçáo). Universidade Estadual Paulista, Marília. 2013.

MITTLER, Peter. Educaçáo Inclusiva: contextos sociais. Porto Alegre: Artmed, 2003.

MONTEIRO, S.S., CONSENTINO, M.M.S., EBELING, G.S. Desenvolvimento moral, muito se fala, mas o que se tem feito? In: I Seminário Internacional Educação para o Século XXI. Anais do I Seminário Internacional Educaçáo para o Século XXI. Campinas, SP: Unicamp, 2018, p. 513-523. Disponível em: <https://www.fe.unicamp.br/eventos/educacaolpg2017/ > Acesso em: 15 maio de 2018 .

PIAGET, Jean. Estudos Sociológicos. Rio de Janeiro: Companhia Editora Forense, 1973. 
PIAGET, Jean. A epistemologia genética. São Paulo: Abril Cultural, 1978.

PIAGET, Jean. O Juízo Moral na criança. São Paulo: Summus, 1994.

SCHIPPER, Carla Maria de. O Processo de Construção da Moral e da Cogniçáo de Crianças com Deficiência Intelectual: Possíveis Interferências Escolares. 2015, 292 f. Dissertação (Mestrado em Educação) Universidade Estadual Do Centro-Oeste, Guarapuava. 2015.

SKLIAR, Carlos. A educação e a pergunta pelos Outros: diferença, alteridade, diversidade e os outros "outros". In: Ponto de Vista, Florianópolis, n. 5, p. 3749, 2003. Disponível em: <https://periodicos.ufsc.br/index.php/pontodevista/ article/view/1244> Acesso em: 10 maio 2016.

A questão da obsessão pelo outro em educação. In: GARCIA, R.L., ZACCUR, E., GIAMBIA-GI, I. Cotidiano: diálogos sobre diálogos. Rio de Janeiro: DP\&A, 2005.

TAILlE, Yves de La; MENI, Maria Suzana de Stefano (Org.). Crise de valores ou valores em crise? Porto Alegre: Artmed, 2009. 



\title{
Aquarela brasileira: fantasmas melaninos, venenos melanômicos

\author{
Brazilian Watercolor: melanin ghosts, melanomic poisons
}

Armando de Melo LISBOA ${ }^{1 *}$

\begin{abstract}
"Essa obrigação histórica em que se acham os homens de cultura africanos de racializar suas reivindicações ... vai conduzi-los a um beco sem saída."
\end{abstract}

(FANON)

\section{Resumo}

A luta antirracista vê-se envolvida cada vez mais em armadilhas decorrentes da traiçoeira e fatal linguagem racializada por ela utilizada, cujas categorias e ontologia, por entorpecer valores éticos e engendrar desumanização, acabam por comprometer a própria luta. Assim, este ensaio discute a ideia duma identidade racial e aponta para a importância crucial da desracialização da práxis política emancipatória para que ela possa alcançar êxito.

Palavras-chave: Racismo. Negritude. Branquitude. Identidade. Fanon.
The anti-racist struggle finds itself increasingly involved in traps resulting from the treacherous and fatal racialized language used by it. The categories and the ontology of this language, by hindering ethical values and engendering dehumanization, end up compromising the struggle itself. Thus, this essay questions the idea of a racial identity and points to the crucial importance of the deracialization of emancipatory political praxis so that it can succeed.

Keywords: Racism. Blackness. Whiteness. Identity. Fanon.

1 Doutor em Sociologia Econômica pela Universidade Técnica de Lisboa (2004). Professor Associado I do Departamento de Economia e Relaçóes Internacionais da Universidade Federal de Santa Catarina. Tem atuado principalmente nas áreas de América Latina, economia solidária, ecológica, popular, filosofia e sociologia econômica, desenvolvimento e ciências da religião. Endereço: CNM/CSE - Campus Universitário - Florianópolis (SC - 88040-900. E-mail: <amelolisboa@gmail.com>.

*Grato pelas sábias observaçóes e sugestóes feitas pelos colegas Paulo Freire Vieira, Gilson Geraldino da Silva Jr. e Márcia Regina Ferreira numa versão preliminar.

\begin{tabular}{l|l|l|l|l|l|} 
R. Educ. Públ. & Cuiabá & v. 28 & n. 67 & p. $105-124$ & jan./abr. 2019 \\
\hline
\end{tabular}




\section{1. "Respeitem meu lado negro"}

"A minha cor é pálida e o meu cabelo, quando deixo crescer, dá para

pentear.

Da Bahia prá cima e da classe média prá baixo, posso dizer que sou branco.”

(CLÁUDIO DA SILVA)

\section{"Por dentro sou cheio de cores." (ARTHUR BISPO DO ROSÁRIO).}

Recentemente, Fabiana Cozza foi vilipendiada por ser escolhida para interpretar Ivone Lara em um musical. Afrodescendente (filha de pai negro e mãe branca), Cozza sempre se reconheceu como negra e, como tal, notoriamente professa absoluta identificação com a cultura afro $^{2}$. Ela manteve sólida amizade com Ivone, com quem gravou e também se apresentou em vários espetáculos. Nei Lopes (2018, p. 75) ousou dizer que desconhecia "cantora brasileira mais capacitada" para personificar Ivone Lara. Contudo, por não ser negra retinta, ela não teria legitimidade para encarnar tal papel. Não se trata, infelizmente, de um caso isolado. Mas serve para ilustrar os dilemas políticos do movimento de construçấo de identidades raciais que, a pretexto de lutar contra a discriminaçâa, acabam por alimentar proselitismos e perfazer formas de racismo invertido.

$\mathrm{Na}$ verdade, algumas vozes relevantes e comprometidas com o movimento negro tomaram posição contrária à hostilização que atingiu Cozza advinda da intolerância que desabrocha, de forma cada vez mais aguda, dentro do próprio movimento negro. Merece destaque o registro de Emicida: "atacar/desrespeitar a Fabiana Cozza é um tiro no pé são tiros no espelho. Tristes tempos esses nossos."3

De fato, o tempo em que a cor da pele é mais importante que o talento é triste e dista cada vez mais daquele sonhado por Luther King, onde pessoas seriam julgadas por sua personalidade, não pela cor de sua pele. $\mathrm{O}$ antológico linchamento

2 Todos seus seis discos fazem referência à cultura afro-brasileira, inclusive expressando sua fé no candomblé. O convite para Fabiana interpretar Ivone adveio da produção do espetáculo, e contou também com o aval da família de Lara, falecida em abril de 2018, aos 96 anos. Como a peça foi concebida há uma década, a própria Ivone já tinha sugerido Cozza para esse papel. Na carta que divulgou reagindo à agressividade sofrida, desistindo então do papel, assinalou: "Renuncio por ter dormido negra numa terça-feira e numa quarta, após o anúncio de meu nome como protagonista do musical, acordar 'branca' aos olhos de tantos irmäos. Renuncio ao sentir no corpo e no coração uma dor jamais vivida antes: a de perder a cor e meu lugar de existência. Ficar oca por dentro".

3 Disponível em: <https://twitter.com/emicida/status/1003373919322234883?lang=pt> 
sofrido por Fabiana Cozza desvela um deprimente cenário, pois, de uma forma surpreendente e inusitada, repóe o racismo, cujo núcleo reside na afirmação de que características físicas determinam não apenas as capacidades humanas mas também o agir moral e psicológico de indivíduos e grupos sociais.

Em outros tempos, Vinicius de Moraes - que com Baden Powell tornou-se pioneiro do afro-samba - queria que "os brancos fossem pretos, e que os pretos fossem brancos." Chico Buarque também admite que Vinicius não teria lugar na sociedade atual, marcada pelo dinheiro e ostentaçáo, na qual tudo é superprogramado e nada é feito sem a intenção de obter um ganho pré-determinado. ${ }^{4}$

Realmente, nosso poeta/diplomata ficaria sem lugar, mas não pelos motivos que Chico aponta. O politicamente correto hoje torna inimaginável um branco apresentar-se como o branco mais preto do Brasil. Os constrangimentos e perseguiçóes que Vinicius sofreria por assim se apresentar - mesmo professando profundo envolvimento com a identidade afro - impossibilitariam que Vinicius se tornasse a figura que conhecemos. Assim como Cozza, a cobrança do lugar de fala de Vinicius impediria-o de entoar ser "negro demais no coração", ou o tornaria inaudível exatamente com setores enegrecidos da sociedade.

$\mathrm{O}$ atual posicionamento da militância e do pensamento negro reflete o surgimento de novas formas de se compreender as relaçóes raciais no Brasil: estamos saindo do extremo assimilicionista, onde imperava a ideologia não existe racismo, rumo à afirmação radical da ideia de raça e da ideologia do separatismo racial. Com uma ampla mobilização indígena, ele é contemporâneo de um profundo e continental movimento de desconstrução da identidade latina que desde o pós-guerra denomina toda a regiâo ao sul do Rio Grande, a qual oculta o fato maior dos grupos populacionais náo latinos serem majoritários. Parte da ideologia latinista é afirmar que a mestiçagem é uma tendência inexorável cuja resultante é uma população cada vez mais homogênea e predominantemente latina, capturando a todos numa perspectiva epistêmica eurocentrada.

Ultrapassando esse discurso de miscigenação embranquecedora e seu correlato mito da democracia racial dissimuladora das formas de racismo brasileiro, luta-se para valorizar as origens africanas e as culturas negras como tấo legítimas para a formação nacional quanto as raízes europeias. Ocorre que nesse processo adota-se um modelo advindo das conquistas históricas dos negros estadunidenses, e que tem por base a fratura binarista negro-branco praticada nos Estados Unidos, onde a pessoa é branca ou é preta, sem gradaçôes intermediárias. Mas sabemos que no

4 Depoimentos de Gilberto Gil e Chico Buarque sobre Vinicius, no filme-documentário "Vinicius", de Miguel Faria Jr. (2005). 
Brasil a linha de cor é ambígua e fluída, tornando a aquarela brasileira uma das mais confusas e complexas do planeta. Nesse cenário, transpor estereótipos raciais exógenos, como estamos a fazer, é excludente, divisionista e deletério. Caetano, aliás, chamou a atenção para essa nossa colorida carnavalização: "Gil é um mulato escuro o suficiente para, mesmo na Bahia, ser chamado de preto. Eu sou um mulato claro o suficiente para, mesmo em São Paulo, ser chamado de branco" (VELOSO, 1997, p. 287).

A tendência de fortalecimento da polarização entre duas essências puras, a negra e a branca, também é amplificada pelo paradigma historiográfico brasileiro que reduz as relaçóes sociais ao antagonismo entre senhores e escravos, como se o Brasil tivesse apenas duas partes, a casa-grande e a senzala. Distorce-se que há muito mais além da relaçáo escravocrata. Uma renovada interpretação da nossa história embasada em ampla documentação demonstra que, apesar do grande número de escravos, a sociedade colonial brasileira não era essencialmente escravista, como esclarece Jorge Caldeira (2009, p. 237). Mesmo sem computar a presença indígena, a população livre compunha a maioria da população brasileira no período. Comparando os dados censitários brasileiros e norte-americanos, Francisco Luna e Samuel Klein constatam que, diferentemente dos Estados Unidos, onde "mais de $95 \%$ da populaçáo livre era branca, na maior parte do Brasil os brancos tendiam a compor menos da metade da população livre" (apud CALDEIRA, 2009, p. 233). ${ }^{5}$

Essa população majoritária livre e de cor não era formada apenas por desclassificados, como explicitou Caio Prado Jr. Ao contrário: com grande parte dela "constituída por pessoas de ascendência africana", ela formava a base para um pujante mercado interno ${ }^{6}$, indo muito além de uma desprezivel economia de subsistência. Chegou, inclusive, a gerar algumas das maiores fortunas do

5 O já clássico e pioneiro estudo sobre os homens livres na ordem escravocrata, de Maria Sylvia de Carvalho Franco, indicava que estes eram "mais numerosos que os escravos existentes", sendo expressivos a ponto dela apontar que a escravidão não deva designar o modo de produção, reduzindo-a a uma "instituição" (1997, p. 35, 13). Do mesmo modo, a obra não menos clássica de John Monteiro informa que no período colonial "a camada mais numerosa da sociedade paulista" era composta de "lavradores pobres e agregados livres, os precursores da 'sociedade caipira”", aos quais se agregavam os índios alforriados que contribuíam "para a expansão de uma população de condição incerta, entre a escravidão e a liberdade", formando "uma sociedade fortemente miscigenada" (1995, p. 218, 211-212).

6 Esta pujança econômica também é a conclusão dos estudos de João Fragoso e Monolo Florentino, apresentados, por exemplo, na magnífica obra "O arcaísmo como projeto". A "metade da populaçấo livre de todo o Brasil constituída por negros e pardos" (conforme o Censo de 1872) - alguns deles também proprietários de escravos - indicaria haver "possibilidades concretas de mobilidade", comprometendo e minando a luta abolicionista (2001, p. 154, 186, 237), o que em parte explica ela ter tardado tanto por aqui. 
planeta naquela época. Conclui Caldeira (2017, p. 100) que a escravidão africana deixa de ser considerada como "a clivagem central para entender a estratificação social e as disputas de classes", pois "não há sustentação empírica para a ideia de um corte radical na sociedade a partir da propriedade de escravos - ou para um papel primordial do "latifúndio agrário-exportador" (CALDEIRA, 2009, p. 269).

Em grande parte, aqueles posicionamentos pretensamente antirracistas se embasam na filosofia do lugar de fala, a qual pressupóe que a melhor estratégia para enfrentar o racismo é desvelar a identidade racial implícita em cada um dos sujeitos sociais. O "lugar de fala" impóe que os brancos "se racializem, entendam o que significa ser branco", ressalta Djamila Ribeiro (2017, p. 69). A perspectiva do lugar de fala náo visa simplesmente abrir espaços para que o subalterno fale e defenda seu direito à humanidade, mas aspira enquadrar a todos numa máscara melanímica. Mais do que localização social, trata-se de localização racial:

Numa sociedade como a brasileira, de herança escravocrata, pessoas negras vão experenciar racismo do lugar de quem é objeto dessa opressão [...] Pessoas brancas vão experenciar do lugar de quem se beneficia dessa mesma opressão. (RIBEIRO, 2017, p. 86, grifo nosso).

$\mathrm{Na}$ busca por desconstruir um universalismo coercitivo, a conceituação/ prática do lugar de fala faz ecoar um erro primário, o da autoridade existencial, já denunciado por Edward Said: "somente mulheres podem compreender a experiência feminina, somente judeus podem compreender o sofrimento judaico, somente ex-colonizados podem compreender a experiência do colonialismo." (apud HOOKS, 2017, p. 112). Portanto, eles estão fora do lugar e, ou náo estáo autorizados a falar, ou seus argumentos, aprioristicamente, são descartados ou reduzidos a um significado marginal, uma vez que, singelamente, se nega a legitimidade de outrem, mesmo quando esse outrem partilhe e participe integralmente da vida do subalterno.

Nessa teoria, para aprender a não ser racista, é necessário, primeiramente, assumir seu lugar racial na estrutura racialista da sociedade, sua identidade racial, inclusive por parte do cidadáo que critica e rejeita o racismo. Isso estimula a identificação racial conforme a diversidade das aparências físicas dos indivíduos. Essa perspectiva classifica o lugar de cada um segundo um padrão colorista bipolar, dividindo todos em dois conjuntos sem intersecção: brancos e não brancos. Pressupondo-se que conformam grupos homogêneos, outras categorias são simplesmente ignoradas. Dilui-se, assim, a aquarela brasileira, tão admirada em todas as latitudes. 
Assim, a luta antirracista privilegia a categoria raça, a qual ajudaria a reconhecer o modus operandi da discriminação racial. Ora, foi o fenômeno do racismo que produziu esse conceito. De forma recursiva, ele reitera e reproduz o próprio racismo. A linguagem nunca é inócua: a lingua sempre foi a companheira do império, admitia Nebrija, autor da primeira gramática de uma língua moderna, o espanhol, em 1492. Como se desvencilhar do racismo usando a mesma categoria que o torna possível? Esse dilema epistêmico é incontornável, como veremos no tópico 4, exigindo o máximo de precauçôes para não se tropeçar numa armadilha e assim almejar algum êxito.

Todavia, a questáo maior aqui náo é a de assumir o risco, praticamente inevitável, de usar a linguagem racializada, mas de fazer cada cidadáo adotar explicitamente uma identidade racial. E isso se alcança por meio duma postura vigilante e combativa por parte da militância e suas organizaçóes. Eliminando todo o amplo espectro das cores tupiniquins, afunda-se numa pantanosa e acirrada disputa sobre o quão branco ou preto cada um é (vide caso de Fabiana Cozza), em que a entidade raça opera plenamente, incendiando relaçóes e gerando ainda mais ressentimentos. Não se trata apenas do uso genérico - que dista de ser inóxio de categorias raciais, mas de enquadrar cada um nessa poderosa camisa de força.

Ora, para aqueles que já são críticos do racismo, essa assunção não altera nada. Contribui apenas para rotulá-los e gerar um certo efeito de distanciamento. E quanto aos racistas, é inverossímil que essa perspectiva faça alguma diferença. A única mudança é que agora afirma-se explicitamente a identificação racial, fomentando-a e reforçando-a, estereotipando ainda mais as pessoas. Ao contrário da questão anterior, de ordem semiótica, essa estratégia identitária é muito mais perigosa, desnecessária e errática.

O lugar de um branco é definido e congelado como o da branquitude, de modo que ele não deva pretensamente falar do lugar de um negro, impedindo-o de obter uma identidade distinta da epidérmica. Como se fosse possível desprovêlo de um sentimento inato de empatia - o que seria muito mais grave. Isso gera uma suspeição e interdição que inibe a possibilidade de falarem juntos, podendo levá-lo a calar sua voz. Por construir o outro de modo essencializado e estereotipado - o lugar cromático de enunciaçáo é o que rege e define a validade do discurso - o lugar de fala não se encontra sob uma perspectiva dialógica, a qual parte da disposição de deixar-se afetar pelo outro. Deslegitima, assim, sua voz e capacidades e, no limite, o excomunga, eliminando um amplo leque de convergências possíveis.

Assim como a capacidade de falar, nascemos dotados do fenômeno da empatia, que nos possibilita entrar na pele do outro, nos abre para o mundo do outro. Ele não brota da razão e sim da aproximação sensível, opera por contágio 
e se amplifica com a convivência, gerando um profundo comprometimento moral e político - o que me comove, me move, diz o ditado. Ao invés de partir e acentuar esse natural e precioso sentir-pensar, grotescamente o lugar de fala afasta-nos dessa pertença empática, apartando os atores sociais pela racionalizaçáo que decreta teu lugar náo é aqui e faz com que muitos se sintam fora do lugar. Reversamente, Fanon (2008, p. 86), em seu trabalho de graduação em psiquiatria, expóe que "uma experiência subjetiva pode ser compartilhada por outra pessoa que não a viva; e não pretendo jamais sair dizendo que o problema negro é meu problema, só meu."

Quando o lugar da fala "interrompe o diálogo", adverte Marcia Tiburi (2017), "então ele corre o sério risco de estar contra si mesmo, de ter regredido a um momento que podemos chamar de anti-político. Se, de dentro da minha dor, eu elimino o diálogo, posso já ter deixado de lado a luta. Posso estar perdido em um exercício de puro ressentimento."

Por isso, em um recente Congresso de Pesquisadores Negros, Ivo Pereira de Queiroz ${ }^{7}$ afirmou: "quando matam um negro que está em mim, matam todos os humanos que estáo em mim. Exijo que respeitem meu lado negro". Por sua vez, a crítica do lugar de fala de Antonio Engelke enfatiza que ela nos leva a pensar que "somente os puros podem falar" (2017, p. 42) - no caso, "somente negros retintos poderiam interpretar Ivone Lara". Ora, jogando-nos na cilada de hierarquizar opressóes, a busca por pureza "náo cessa de mover as fronteiras que demarcam a construção do inimigo, trazendo-as cada vez mais para o interior do próprio campo progressista." (p. 43).

Com uma postura autofágica e fraticida, incidimos em inacreditáveis práticas essencialistas de pureza de sangue, estimulando, literalmente, a regressáo das lutas e do imaginário utópico e emancipatório. Bloqueamos, assim, o surgimento de uma sociedade mais igualitária e substantivamente democrática. Se estamos em lugares diferenciados (e alguns de privilégio), há que combater aquilo que produz esses lugares diferenciados em que estamos em conjunto com todos os que se dispóem para tal luta.

Do ponto de vista libertário, ninguém deve dispor de monopólio exegético, muito menos quando essa posição de autoridade é definida por critérios raciais. Tratase de uma prerrogativa inaceitável, pois inepta e regressiva, ou seja, incongruente com as promessas emancipatórias. Em outras palavras, mesmo sendo reconhecido como aguerrido, politizado e até erudito na aparência, esse "radicalismo" revela-se estreitador e incompatível com as esperanças e mudanças postas pelas lutas sociais de hoje, castrando a multiplicação de lugares de potência transformadora.

7 Palestra no III Copene-Sul (UFSC, julho/2017). 
A luta do movimento negro tem inúmeros méritos e logros, sendo talvez o maior o de ter colocado o racismo na agenda pública brasileira. Mas a radicalização de seus setores acaba levando-o a cair na armadilha do isolacionismo étnico e, paradoxalmente, a prolongar a herança colonial - o que seria ainda pior. Pois a raça é a mais central e maléfica categoria do processo colonial. Numa incrível inversão de polarizaçóes, usa-se da mesma régua colonial-racista, mas com sinais contrários, para medir, classificar e discriminar pessoas conforme a cor de sua pele, com os próprios vitimados combatendo "não contra a pertença do Negro a uma raça distinta”, esclarece Achile Mbembe (2014, p. 159), mas contra a inferioridade justaposta à sua "raça".

A melanina e condiçóes de nascimento continuam a aprisionar e danar as pessoas. Este pecado original - que estigma todos ao simplesmente nascer - se renova, agora não mais como imposição senhorial, e sim como uma condição inalienável afirmada pela militância social negra - imbuída de teorias que, pretensamente, querem corrigir uma iniquidade histórica. O "racismo antirracista" (FANON, 1968, p. 114) é uma forma insidiosa - e aqui reside sua periculosidade - que se impregna na vida democrática, contaminando-a.

Se queremos estar à altura do nosso tempo, há que sair desse atoleiro. A superaçáo da redoma míope e sectária que reveste atualmente o movimento negro passa pela desracialização da linguagem por ele adotada, inclusive pelo abandono da ideia duma identidade racial negra, como discutiremos nos próximos tópicos. Não é uma tarefa simples, mas sem independência de espírito, autocrítica e coragem, a aventura do permanente combate pela dignidade humana ficará cada vez mais distante.

\section{Crítica fanoniana à negritude}

"No campo de batalha, limitado nos quatro cantos por vintenas de negros pendurados pelos testículos, ergue-se pouco a pouco um monumento que promete ser grandioso. E, no cume deste monumento, percebo um branco e um negro que se apertam as mãos." (FANON)

Assombrosamente, aquelas posturas sectárias vão na contramão do que afirmam alguns dos mais célebres e iminentes pensadores comprometidos com a emancipação dos negros. É o caso de Frantz Fanon, uma relevante e radical figura da luta anticolonial africana. Tendo lutado contra o nazismo na Segunda Guerra Mundial e contra o imperialismo francês na guerra Franco-Argelina, proclamou, como transparece na epígrafe acima, que não se pode agir politicamente com rancor e ressentimento: "o racismo, o ódio, o ressentimento, 'o desejo legítimo de 
vingança’ não podem alimentar uma guerra de libertação.” (1968, p. 114). Ele fincou esclarecimentos valiosíssimos contrários a essa radicalização (ou melhor, racialização) estreitadora, estereotipada e retrógrada sobre a cor da pele para demarcar posicionamentos políticos. Esse afro-franco-argelino-caribenho não cansou de alertar sobre a contraproducente deformação maniqueísta presente na ideologia da negritude, como o fez, por exemplo, quando ela penetrou nas Antilhas: "Parece-me que os antilhanos, depois de viver o grande erro branco, estão agora vivendo a grande miragem negra." (apud ORTIZ, 2014, p. 433).

Sua dura crítica do racismo às avessas e dos maniqueísmos esterilizadores ficou transparente tanto nos "Condenados da terra" (FANON, 1961, 1ª edição), quanto em "Pele negra, máscara branca" (1952, 1a edição). Essa última obra adverte que o negro, sendo "uma construção do branco", "se joga no grande buraco negro" no qual "rejeita a atualidade e o devir em nome de um passado místico" (2008, p. 30-31). Prognostica que, enquanto os negros compreenderem sua condição humana a partir da assunção da epidermização em que foram enquadrados e lhes inferiorizou, enquanto assumirem que sua pele negra os identifica e continuarem a se ver racializados, permaneceráo capturados pelo olhar racial europeu e prosseguirão vendo-se a si mesmos pelos olhos brancos, ou melhor, das máscaras brancas desse deformante olhar.

Animalizados pelo colonialismo, Fanon insistirá que a existência dos condenados se encontra abaixo da linha do humano, que o negro é um não-ser: "o negro não é um homem" (2008, p. 26). A luta de libertação da condição colonial visa "passar do estado animal ao humano", desvesti-lo da pseudo pele ontológica que o branco lhe impôs e reintegrá-lo simplesmente como homem, processo que reabilitará também, se possível, o próprio "carrasco" (1968, p. 103, 255).

Nessa direção, contesta vigorosamente um prefácio de Sartre a uma pioneira antologia da poesia negra, onde ele, citando Césaire, saúda "o grande grito negro que abalará os assentamentos do mundo" (FANON, 2008). A essa afirmação, Fanon contrapóe que o seu grito "não será nada negro", pois "o erro de Sartre" é querer helenizar, orfeizar "a este negro que procura o universal" (2008, p. 121, 43, 158). Afirma ainda que "Sartre mostrou que o passado [...] 'aprisiona”. Todavia,

[...] não é o mundo negro que dita minha conduta. Minha pele negra não é depositária de valores específicos. [...] Não sou prisioneiro da História. [...] Não sou escravo da escravidáo que desumanizou meus pais. [...] Sou um homem e é todo o passado do mundo que devo recuperar. (2008, p. 187-190). 
Sem se deixar aprisionar pela ilusão do destino, ele não se conformou à tirania da fatalidade. Como Todorov (2005, p. 212), "o homem pode superar-se; é nisso que ele é humano" - entendeu que viver é fazer escolhas, é devir; já que nada está pré-fixado, cada um pode se reinventar "a todo instante". Todos podemos, portanto, invocar uma identidade distinta da que nos foi outorgada ao nascer, como demonstra hoje a teoria de gênero. Assim, enfatizou que

[...] o verdadeiro salto consiste em introduzir a invenção na existência. No mundo em que me encaminho, eu me recrio continuamente. (...) Não se deve tentar fixar o homem, pois o seu destino é ser solto. A densidade da História não determina nenhum de meus atos. (FANON, 2008, p. 189-190).

Em "Condenados da Terra" descreve que os intelectuais colonizados, em sua luta "para escapar da supremacia da cultura branca", sentem "a necessidade de regressar a raízes ignoradas" e, privilegiando costumes e tradiçóes, perfazem uma "banal busca de exotismo" para "reencontrar o povo": querer "reencontrar o povo é (...) querer ser negro (...) um verdadeiro negro" (1968, p. 181, 183).

Ora, o colonizado teima em proclamar a existência de uma cultura africana, mas essa é uma invenção colonial. O "Negro", esclarece, é uma categoria genérica criada pelo colonialismo para rotular um "vasto continente" e condená-lo como "uma toca de selvagens, uma regiāo infestada de superstiçóes e fanatismo". Buscando "escapar da dentada colonial", os "esforços do colonizado (...) inscrevem-se logicamente numa perspectiva que é a mesma do colonialismo". O negro "jamais foi táo negro como a partir do instante em que esteve sob o domínio do branco" (1968, p. 176). Fanon sabe que o "Negro" espelha e inverte o racismo europeu, sendo sua antítese:

[...] à afirmação incondicional da cultura europeia sucedeu a afirmação incondicional da cultura africana. (...) O conceito de negritude era a antítese afetiva senão lógica desse insulto que o homem branco fazia à humanidade. Essa negritude exacerbada contra o desprezo do branco revelou-se em certos setores apenas capaz de suspender interdiçôes e maldiçôes. (1968, p. 177; 176).

Ele entende que a racialização com as cores branca e preta é uma fantasmagoria insana que aprisiona duplamente tanto o branco quanto o preto $^{8}$, dilacerando a sociedade, pois impede reconhecerem-se em sua comum condição humana:

8 "Negrura" e "brancura" são um "drama narcisista, [onde] cada um [fica] enclausurado na sua particularidade" (2008, p. 166; 56). 
[...] existem dois campos: o branco e o negro. Tenazmente, questionaremos as duas metafisicas e veremos que elas são frequentemente muito destrutivas. [...] O negro [...] fica enclausurado no próprio corpo. [...] O branco está fechado na sua brancura. $\mathrm{O}$ negro na sua negrura. [...] Trabalhamos para a dissolução total desse universo mórbido, [...] [para] afastar estes dois termos que são igualmente inaceitáveis e, através de uma particularidade humana, tender ao universal. (2008, p. 26-27; 186; 166, grifos nossos).

Portanto, ciente da unicidade da condição humana e da "potência extraordinária” da linguagem, a qual define o modo de ser e aprisiona implacavelmente o olhar num "círculo infernal", Fanon recusa essa amputaçáo (2008, p. 34; 39; 109; 126) que a cissiparidade da cor engendra. Contestando dessa forma o apelo ao colorismo racial, grita repetidamente: "não existe problema negro [...], náo existe fardo branco [...], pretendemos, nada mais nada menos, liberar o homem de cor de si próprio [...], trata-se de deixar o homem livre" (2008, p. 43; 189; 26).

Como psiquiatra, Fanon entendeu claramente que o problema do racismo não é de caráter étnico, mas semiótico e espiritual, que a "desalienação dos negros" para levá-los "a não serem mais escravos dos seus arquetípicos" passa pela transformação da linguagem racializada que sustenta e fixa o olhar que lhe faz sentir "o peso da melanina" (2008, p. 49; 47; 133). Propôs, na conclusão dos "Condenados", romper com o narcisismo europeu, em que "palavras, agregados variados de palavras, as tensóes nascidas dos significados contidos nas palavras" produzem realidades obscenas e delirantes (1968, p. 273). Nesse sentido, no limite, a conhecida afirmação de Morgan Freeman, em uma entrevista - "o que é preciso para sair do racismo? Parar de falar sobre ele!”, é rigorosamente fanoniana.

"Aprisionados no calabouço das aparências" - observa agudamente Mbembe (2014, p. 12) - o único modo de "brancos" e "negros" saírem da doentia "enorme jaula" do racismo, onde estáo indesatavelmente enclausurados e da qual surgem como versōes do mesmo distúrbio patológico, é erradicando a crença em raças e renunciar a usar do venenoso léxico cromatológico para se autoidentificarem. Por isso, Fanon, sabedor que "a neurose não é constitutiva da realidade humana" (2008, p. 134), clinicamente recomenda: "A liberação dos complexos de ódio só será obtida se a humanidade souber renunciar ao complexo de bode expiatório." (2008, p. 156).

Em sua luta para "simplesmente ser um homem entre outros homens" - "não tenho o direito de ser um negro" (2008, p. 106; 189), bradou - Fanon não se cansou de apelar ao seu mestre Aimé Césaire e proclamar que a cor não amputa a tomada de consciência da humanidade comum: "minha negritude não é torre 
nem catedral. Ela mergulha na carne vermelha do solo. Ela mergulha na carne ardente do céu."

Foi com essa postura de alcançar um mundo desembaraçado do "fardo da raça" que Fanon, em sua obra derradeira, "Damnés", advertiu que "a elaboração do conceito de negritude" conduzirá os africanos "a um beco sem saída" e degradará ainda mais sua sociedade, que esse conceito, com o "processo de descolonização" e "libertação dos povos" deixaria de fazer sentido pois "não haverá cultura negra" uma vez que "os negros estão desaparecendo". Nessa mesma linha, ao contestar esse conceito, discordou também da adoção do mesmo por Léopold Senghor, um dos seus apóstolos criadores e entáo Presidente do Senegal, como programa de estudo nas escolas, caso a preocupação não seja de ordem histórica, mas visando "fabricar consciências negras" (1968, p. 178-179; 26; 195-196).

Enfatizará, ainda, que a negritude esbarra no limite de que "a cultura negroafricana se fragmentou” (1968, p. 180). Por não haver uma essência ontológica, as dinâmicas contingentes da história e as interdependências econômicas são "mais fortes que o passado" que se quer reviver. Como "a experiência negra é ambígua", e tendo se dispersado ainda mais com a diáspora, inexiste uma unidade da "raça negra" (2008, p. 123; 149): os problemas que se colocam aos negros americanos "não se assemelhavam aqueles com que se defrontavam os negros africanos". No caso do mundo norte-africano, os Estados árabes hoje são tão "organicamente ligados às sociedades mediterrâneas de cultura", e a tal ponto "estranhos uns aos outros, que um encontro mesmo cultural entre esses Estados se revela um disparate" (1968, p. 179-180).

A inexistência duma comunidade homogênea de interesses - "não há um preto, há pretos" (2008, p. 123); "há negros que são mais brancos que os brancos" - se apresenta quando os colonizados declaram que falam como "senegalês e francês"; "argelino e francês"; "nigeriano e inglês" (1968, p. 118; 181). O próprio Fanon, ao questionar "que história é essa de povo negro, de nacionalidade negra?", autodeclarou-se: "sou francês" $\left(2008\right.$, p. 170) ${ }^{10}$. Assim, a unidade africana, se for possível, deve ser buscada em termos políticos, e não culturais, pois ela ganha densidade é em torno da "luta de libertação dos povos" (1968, p. 196).

Apesar do clássico embate crítico de Fanon com o movimento/conceito da negritude, quando do auge da difusáo desse nas lutas anticoloniais na África durante a Guerra Fria, tais posturas ressurgem como sinal dos tristes tempos atuais.

9 Mbembe (2014, p. 282).

10 Não hesitou, entretanto, em lutar contra a França no contexto da guerra pela independência da Argélia. 


\section{Dilemas da racialização identitária}

"El sistema de construcción binario de identidades ha operado en detrimento de la posibilidad de opción de las personas, en detrimento de la necesidad de búsqueda y construcción de subjetividades distintas, múltiples. (...) La constitución de las identidades de género, raza, etnia, etc., se convierte en un verdadero ejercicio de represión, de regulación y sujeción de los sujetos.”

(YUDERKYS ESPINOSA)

Colorir e racializar os seres humanos é um modo de essencializar o outro - estereotipando-o com uma cor e identificando-o de forma monolítica e homogênea em torno de um único aspecto da vida, o das aparências - o que permite objetificá-los, torna-los coisa, mercadoria. Ou seja, a ontologia da raça reifica a diferença como parte da nossa natureza, como se os genes pudessem transmitir cultura.

A negra-lesbiana Yuderkys Espinosa, partindo das teorias de gênero, afirma que o sistema de repressáo dos corpos se reproduz enquadrando-os em pares binários e polarizados, fixando-se num deles como central e dominante. Esse binarismo estereotipante e mutilador "perpetua a crença na coerência interna e casualidade entre sexo-gênero e fisionomia-raça” (2007, p. 32). Segundo essa lógica, o sujeito assujeitado náo tem outra opção a não ser confinar-se no lugar identitário que lhe foi determinado. Portanto, a imutabilidade dessa identidade atribuída não está a serviço das causas emancipatórias, mas desse poder binário de dominação. Transgredi-lo e superá-lo exige optar pelo tertium datur e adotar uma perspectiva trans, ou seja, ir além das antinomias constitutivas da modernidade ocidental.

Não há uma identidade verdadeira e estática. Ao invés de um único atributo identitário, todos temos múltiplos pertencimentos e lugares (orientaçáo sexual; religiâo; etnia; classe; idade, etc.). "Cada indivíduo é portador de múltiplas culturas", esclarece Todorov (2010, p. 106). Também Said (2011, p. 510, grifo nosso):

Hoje em dia ninguém é uma coisa só. Rótulos como indiano, mulher, muçulmano ou americano não passam de pontos de partida que, seguindo-se uma experiência concreta, mesmo que breve, logo ficam para trás. O imperialismo consolidou a mescla de cultura e identidades numa escala global. Mas, seu pior e mais paradoxal legado foi permitir que as pessoas acreditassem que eram apenas, sobretudo, exclusivamente brancas, pretas, ocidentais ou orientais. 
A identificação é um processo multidirecionado, contingente e indeterminado, que não é fruto de uma imaginária essência embasada numa natureza primordial. A militância negra ainda não aprendeu com o "vasto acervo de lições" advindas da "história do Atlântico negro" sobre a "mutação" e "instabilidade" das identidades, levando em conta que elas "estão sempre inacabadas, sempre sendo refeitas", agrega Paul Gilroy (2012, p. 30). Aliás, o mesmo autor, em sua obra clássica, procura "repudiar as perigosas obsessóes com a pureza 'racial' que se encontram em circulação dentro e fora da política negra" (ibid., ibid.). Assim como Fanon, ele preocupou-se em "resistir à disciplina marcial de todos os projetos de libertaçâo nacional" (2012, p. 22).

Fanon denunciou que o "beco sem saída" da obrigação histórica dos intelectuais africanos em "racializar suas reivindicaçóes" decorre da "procura apaixonada de uma cultura nacional anterior à era colonial". Acreditar que se possa restituir "à cultura nacional seu valor e seus contornos antigos" seria uma mistificação e um erro. Pois "não há hibernação da cultura", não é possível “juntar-se ao povo nesse passado em que ele já não está mais". Como "a tradição muda de significação" e "a cultura foge de toda simplificaçáo", os "estoques de particularismos" são apenas "farrapos mumificados", revestimentos e reflexos "de uma vida subterrânea densa, em perpétua renovação". Apenas um "populismo abstrato" pode julgar "descobrir a verdade do povo" (1968, p. 174; 205; 195; $188 ; 186 ; 185 ; 194)$.

Querer apegar-se à tradição ou reatualizar as tradiçóes abandonadas é ir náo somente contra a história, mas contra seu próprio povo. [...] Os homens de cultura africanos que se batem ainda em nome da cultura negro-africana, que multiplicaram os congressos em consideração à unidade dessa cultura, devem hoje perceber que sua atividade se reduz a confrontar fragmentos ou comparar sarcófagos. (FANON, 1968, p. 186; 194).

Por sua vez, no que tange à questão identitária, Walter Mignolo adota uma sofisticada posição onde perfaz sutis distinçôes entre "política de identidade" - da qual "açóes afirmativas e multiculturalismo" são expressôes - e "identidade em política", sendo essa de importância "crucial para a opção decolonial”. Quanto à primeira tese, registre-se, argumentou sobre o "perigo" da "política identitária" do "ser negro ou branco, mulher ou homem" quando esta adota "posiçóes fundamentalistas" baseando-se "na suposição de que as identidades são aspectos essenciais dos indivíduos", o que pode "levar à intolerância". As dicotomias, afirma, "não são ontológicas, mas hermenêuticas" (2008, p. 323; 289; 308). 
Nesse sentido, ao discutir sobre a identidade africana, Appiah (1997, p. 250) concluiu que "a concepção racializada da própria identidade é um retrocesso". Todavia, essas objeçóes, ou mesmo argumentar o dado biológico de que raças não existem, não alteram em nada a percepção cotidiana da sua presença física. Infelizmente, "a existência do racismo não requer a existência de raças", lembra Todorov (apud APPIAH, 1997, p. 243).

Com efeito, africanidade não pressupóe necessariamente racialidade. Mas isso pouco importa. O secular processo de exploração das pessoas de origem africanas racialmente escravizadas conectou de tal modo os termos África e negro que é praticamente impossível aceitar que existam africanos não negros. A construção da identidade negra se reporta, necessariamente, a essa história, ao mito da origem africana. Ser negro expressa uma consciência afrocêntrica, uma história primordial. A alma africana é o suporte da essência do ser negro. No entanto, esclarece Gilroy (2012, p. 24),

[...] a África atual é substituída por significantes icônicos de um passado africano genérico e ideal [...]. Isto pode ter sido uma fantasia desculpável durante o período do Black Power, do funk e do soul, mas é uma opçáo profundamente repulsiva na era da globalização do hip-hop e da multicultura corporativa.

Convencido da "inevitabilidade" e do "valor legítimo da mutação, hibridez e mistura em marcha", as quais propiciarão "memórias do racismo e da cultura política negra melhores do que aquelas até agora oferecidas por absolutistas culturais de vários matizes fenotípicos", Gilroy repudia tanto a "indiferença" e "ignorância" da "concepção eurocêntrica de modernidade", quanto a deprimente "nulidade" e "banalidade" do "pensamento 'afrocêntrico". Ele entende assim que o conflito político do novo século terá por eixo central não mais "a linha da cor, mas o desafio do desenvolvimento justo e sustentável” (2012, p. 415; 398).

"Correntes ideológicas que se dizem progressistas e radicais" estabelecem uma "quase-equivalência entre raça e geografia", territorializando a identidade e racializando a geografia, reconhece Mbembe. Com o nome "África" assemelhandose mais a "uma máscara", observa também que o continente se tornou um "poço de alucinação", de "fantasias". Todavia, já que em qualquer identidade inexiste autenticidade, pragmaticamente, Mbembe não recusa a identidade negra, mas defende que ela "só pode ser problematizada enquanto identidade em devir", inscrita no "devir-negro do mundo". Dessa forma, permitiria ao negro "redescobrirse como fonte autônoma de criação, avaliar-se como humano, encontrar sentido e fundamento naquilo que é e faz." (2014, p. 160-161; 96; 75; 127; 166; 21; 165). 
Propóe, então, abraçar "o significante negro [...] para melhor o turvar e assim melhor nos afastarmos, para melhor o desviar e para melhor afirmar a dignidade inata de cada ser humano." (289).

Identidades são inventadas e não refletem essências. Assim como o gênero - "não se nasce mulher, torna-se mulher", desvelou Simone de Beauvoir identidades são construçóes sociais, ainda que, no caso da raça, um lamentável construto. A identidade negra, moldada pelas experiências da discriminação racista e da solidariedade negra - forças reais e poderosas - é palpável e sentida, literalmente, na pele, e se constata diariamente nas entrevistas de emprego, abordagens policiais, prisóes ou nos teatros, restaurantes e clubes de luxo.

É quase impossível não se referir a esse fenômeno sem utilizar o popular léxico das cores, "linguagem totalmente imperfeita, dúbia, desadequada" ${ }^{11}$, pois o próprio linguajar faz reviver diariamente a fantasmagoria das raças, gerando ainda mais mal ${ }^{12}$. Todavia, insulto ainda maior seria simplesmente silenciar e ocultar a existência diária do racismo. "Tornar pronunciável o segredo culposo da raça [...] permite sua explicitação”, defende Liv Sovik (2009, p. 83). A racializaçáo colocanos, portanto, num delicado impasse epistêmico.

As palavras nunca são unívocas: admitem distintos significados, para além do enunciado primário que o signo quer designar. A ambiguidade dos seus significados, e a materialização daquele que será apropriado, depende do contexto, das intersubjetividades dos sujeitos envolvidos, da entonação e do olhar de quem as pronuncia. Assim como um uso náo sexista da expressão mulher aos poucos se generaliza, do mesmo modo as categorias coloristas para se referir ao ser humano podem ter - e têm - um uso corriqueiro isento de conotaçóes raciais e racistas ${ }^{13}$. Nesse sentido, o uso pragmático da alegoria das cores, utilizado não de forma identitária, mas metaforicamente, como uma metonímia, para se referir ao ser humano considerando um dos seus aspectos, sem aviltá-lo e diminuí-lo, é uma prática usual e perfeitamente admissível. A representação de um ser humano nunca deve inferiorizá-lo perante outrem. E isso se define não necessariamente com o uso desse ou daquele termo genérico, mas com o olhar, o sentido com o qual se está a usar aquele termo.

11 Mbembe (2014, p. 25).

12 Appiah (1997, p. 75).

13 Apesar do espantoso gradiente de possibilidades melaninas da espécie humana, a ótica da identidade racial, como se estivéssemos prisioneiros da história, nos deixa apenas duas máscaras. Ao contrário, nossas possiblidades sexuais não dispóem de tamanho gradiente, em que pese sua multiplicidade. Mas a teoria de gênero não tolhe, pelo contrário, busca ampliar ao máximo o jogo do possível, enriquecendo as possibilidades colocadas à disposição da humanidade. A dicotomia cromática é uma camisa de força maniqueísta. Querer impô-la é operar uma vivissecção no complexo e multicolorido corpo social. 
Se a ideia da negritude permite tomar consciência do sofrimento de um povo, há que ter algumas precauçóes, pois o uso acrítico do linguajar racialista nos leva a "reificar a diferença social" (GILROY, 2012, p. 24), a hipostasiar a raça e a "tornar reais as identidades imaginárias a que a Europa nos submeteu" (APPIAH, 1997, p. 96). Quando estigmas raciais são utilizados de forma ampla e generalizante, uma pele ontológica nos desgraça e devora, e o mundo como um todo permanecerá invertido. Diante disso, o próprio Césaire, um dos pais desse conceito, ressalvou: "estou a favor da negritude desde um ponto de vista literário e como ética pessoal, porém estou contra uma ideologia fundada na negritude." (apud OLLÉ-LAPRUNE, 2008, p. 22).

Como vimos, Appiah (1997, p. 244-246) é um crítico da visão de que os africanos devam "unir-se em torno da Pessoa Negra" - concepção "perigosa na prática e enganosa na teoria: a unidade africana e a identidade africana precisam de bases mais seguras do que a raça." Contudo, defende que não é o caso de "jogarmos fora a falsidade" de uma solidariedade fundada na raça, a qual pode ter valor com a condição de se reconhecer que "a raça, a história e a metafísica náo impóem uma identidade: que podemos escolher”.

\section{Considerações finais}

"Fanon aponta, por um lado, para a defesa de uma dialética crítica que rejeita o essencialismo implícito no coletivismo forçado da raça e da nação e, por outro lado, recusa o universalismo abstrato próprio ao humanismo europeu para afirmar um novo humanismo, voltado à desracialização da experiência."

(DEIVISON FAUSTINO)

A crítica a um suposto essencialismo (ou ao risco de) sob o qual gravitam os conceitos negro e negritude não é agenciada aqui para desqualificar os sujeitos colonizados em luta contra o silenciamento e a inferiorização que lhes é imposto. Para romper com as síndromes de colonialidade e subordinação ainda vigentes na cultura moderna, o ponto de partida são as experiências humanas desperdiçadas. Não podemos continuar cegos a elas. Cabe-nos reconhecê-las e com elas dialogar. A descolonização também é epistêmica, ou seja, descansa em projetos políticos epistemicamente pluriversais, enfatiza a perspectiva decolonial, fazendo-se, portanto, com diversidade epistêmica. Epistemologias etno-raciais e feministas desafiam a hegemonia do discurso epistêmico ocidental, que se apresenta como neutro, objetivo e desinteressado, encobrindo que fazem do seu lugar de enunciação um privilégio epistêmico e inviabilizando todos os demais. 
Como um corretivo com prazo de validade, a construção e a afirmação da diferença identitária e epistêmica é um passo necessário na reconstrução da humanidade destruída pelo processo colonizador e mercantil. Elas fazem sentido, todavia, na perspectiva da solidariedade com a humanidade como um todo. Essa é a conclusão da crítica de Mbembe à razão negra:

Enquanto não se puser fim à funesta ideia da desigualdade das raças e da seleção entre diferentes espécies humanas, a luta das gentes de origem africana por aquilo a que poderemos chamar 'igualdade de partes' - e portanto, de direitos e responsabilidades - continuará a ser uma luta legítima. Para tal, no entanto, tem de ser conduzida não com o objetivo de se separar de outros seres humanos, mas em solidariedade com a própria Humanidade - esforçandose, através da luta, por reconciliar os múltiplos rostos da Humanidade. (MBEMBE, 2014, p. 295).

Ler isso é praticamente ouvir o eco de Fanon (1968, p. 26; 205), que discerniu que o "desaparecimento do colonizado" com o "processo de descolonização" inaugura uma "nova humanidade, para si e para os outros", "um novo humanismo" com "dimensão universal". Inserida no permanente processo do devir humano, a "reivindicação nacional" é uma etapa necessária - pois somente se alcança o universal a partir das singularidades - e, se for "verdadeira, isto é, se traduz o querer manifesto do povo [...] então a construção nacional acompanha-se necessariamente da descoberta e da promoção de valores universalizantes." (1968, p. 206).

Já é "tarde demais para escaparmos uns dos outros" (APPIAH, 1997, p. 110). Enquanto não chegarmos a um "mundo para-lá-das-raças", e para lá chegar, celebrar a alteridade exige "resistir às sereias da insularidade" e abrir-se para a humanidade comum, para nosso único mundo, "para um futuro comum, com dignidade para todos" (MBEMBE, 2014, p. 269; 296). Inspirado em Fanon, e lhe dando continuidade, Mbembe declara que a proclamação da diferença hoje necessária "é apenas um momento de um projeto mais vasto, de um mundo que virá [...] no qual o destino é universal, um mundo livre do peso da raça e do ressentimento." (2014, p. 306).

$\mathrm{Na}$ perspectiva fanoniana, uma práxis negra apenas cumprirá sua missão antirracista caso rompa com fechados identitarismos, se reinvente, se conecte com o vir-a-ser humano e marche "em companhia do homem, de todos os homens" (FANON, 1968, p. 274). Caso contrário, as máscaras melanínicas morbidamente incubarão destrutivos melanomas. 


\section{Referências}

APPIAH, Kwame. Na casa de meu pai. Rio de Janeiro: Contraponto, 1997. CALDEIRA, Jorge. História do Brasil com empreendedores. São Paulo: Mameluco, 2009.

. História da riqueza no Brasil. Rio de Janeiro: Estação Brasil, 2017.

ENGELKE, Antonio. Pureza e poder. Piauí, set. 2017.

ESPINOSA, Yuderkys. Escritos de una lesbiana oscura. Buenos Aires: En la frontera, 2007.

FANON, F. Os condenados da terra. Rio de Janeiro: Civilização Brasileira, 1968. . Pele negra, máscara branca. Salvador: EDUFBA, 2008.

FRAGOSO, João; FLORENTINO, Monolo. O arcaísmo como projeto. Rio de Janeiro: Civilização Brasileira, 2001.

FRANCO, Maria S. Homens livres na ordem escravocrata. 4. ed. São Paulo: Unesp, 1997.

GILROY, Paul. O Atlântico negro. 34. ed. São Paulo: Ed. 34, 2012.

HOOKS, Bell. Ensinando a transgredir. São Paulo: Martins Fontes, 2017.

LOPES, Nei. Lara, Cozza e as feridas abertas. Época, n. 1041, 11 jun. 2018.

MBEMBE, Achile. Crítica da razáo negra. Lisboa: Antígona, 2014.

MIGNOLO, Walter Desobediência epistêmica: a opção descolonial e o significado de identidade em política. In: Cadernos de Letras da UFF, n. 34, 2008.

OLLÉ-LAPRUNE, Philippe. El poeta de la palavra hermosa como el oxígeno naciente: Aimé Césaire. In: Para ler a Aimé Césaire. México: FCE, 2008.

ORTIZ, Renato. Frantz Fanon: um itinerário político e intelectual. Contemporânea, v. 4, n. 2, 2014.

RAMOS, Alberto Guerreiro. Patologia social do 'branco' brasileiro. In: Introduçáo crítica à sociologia brasileira. Rio de Janeiro: UFRJ, 1995.

RIBEIRO, Djamila. O que é lugar de fala? Belo Horizonte: Letramento, 2017.

SAID, Edward. Cultura e imperialismo. São Paulo: Cia. das Letras, 2011. 
SOVIK, Liv (2009). Aqui ninguém é branco. Rio de Janeiro: Aeroplano, 2009.

TIBURI, Marcia. Lugar de fala e lugar de dor. Revista Cult, 29 mar. 2017. Disponível em: <https://revistacult.uol.com.br/home/lugar-de-fala-e-eticopolitica-da-luta/> Acesso em: 21 jun. 2018.

TODOROV, Tzvetan. O jardim imperfeito. São Paulo: Edusp, 2005.

VELOSO, Caetano. Verdade tropical. São Paulo: Cia. das Letras, 1997. 
Educação Ambiental 



\title{
Formação continuada em Educação Ambiental: uma proposta em movimento
}

\author{
Continuing education in Environmental Education: \\ an action in movement
}

\author{
Raquel Fabiane Mafra ORSI ${ }^{1}$ \\ Antonio Fernando Silveira GUERRA ${ }^{2}$
}

\begin{abstract}
Resumo
$\mathrm{O}$ artigo apresenta um estudo desenvolvido a partir da experiência vivida nas formações continuadas de professores da Gerência de Educação de Itajaí-SC. O objetivo foi refletir sobre os elementos essenciais na formaçáo continuada que ampliem a inserção da educação ambiental na escola. Utilizaram-se entrevistas reflexivas com nove professores, o que possibilitou a construção da proposta da mandala, a qual nos remete ao movimento da formaçáo do educador que valoriza o ser, o sentir e o agir, o olhar para suas potencialidades realizadas no seu mundo vivido, dialogando sobre suas práticas educativas e sociais.
\end{abstract}

Palavras-chave: Experiência vivida. Educação Ambiental. Formação Continuada.

\begin{abstract}
This article introduces a study developed from the experience lived throughout continuing education of teachers in Management of Education in Itajaí-SC (GERED). The aim was to reflect on the essential elements in continuing education which spread out the insertion of environmental education in schools. The research was carried out through thoughtful interviews with nine teachers, enabling the construction of the mandala, which leads to the movement of educator's development, consequently expressing values of being, feeling and acting, looking at one's potentials performed on their living world, dialoguing about their educational and social practice.
\end{abstract}

Keywords: Living experience. Environmental Education. Continuing Education.

1 Doutora e Mestre em Educação pela Universidade do Vale do Itajaí. Integrante grupo de Pesquisa Educação, Estudos, Ambientais e Sociedade (GEEAS). Técnica na Gerência de Educação, na Agência de Desenvolvimento Regional de Itajaí-SC. Secretaria de Estado do Desenvolvimento Regional - Itajaí (SC), Gerência de Educação. Rua Jorge Mattos, Centro, 88302130 - Itajaí-SC- Brasil. Telefone: (47) 33985993. E-mail: <mafraorsi@yahoo.com.br>.

2 Pós-Doutor em Educação Ambiental, Doutor em Engenharia de Produção - Mídia e Conhecimento; Mestre em Educação, Prof. do Programa de Pós-Graduação em Educação da Universidade do Vale do Itajaí. Universidade do Vale do Itajaí, Programa de Pós-Graduação Mestrado em Educação. Rua Uruguai, 458 - Bloco F7 - 4 andar - sala 10 Fazenda 88302202 - Itajaí-SC-Brasil - Caixa-postal: 360 Telefone: (47) 33417516 Ramal: 8005 Fax: (47) 33417822 URL da Homepage: <http://www.univali.br/ppge>. E-mail: $<$ afguerraea@gmail.com>.

R. Educ. Públ.

Cuiabá

v. 28

n. 67

p. $127-148$

jan./abr. 2019 


\section{Introdução}

Para discutir as questões ambientais na Educação, é necessário o educador ambiental ter, em mente, que estará abordando questóes que exigem mudanças de concepções e representações, transformaçôes sociais, alterações de pensamento, articuladas com mudanças de hábitos, de atitudes e valores e da forma de agir do ser humano, consigo mesmo, na relação com o outro e com meio em que está inserido - local e global.

É uma tarefa nada fácil realizar essa transformação, porém acreditamos ser possível que ela ocorra. Não pretendemos ser ingênuos ao abordar o tema dessa forma, mas apontar o quanto essas questóes nos tem mobilizado na busca de orientaçóes e suportes que propiciem um alicerce objetivo para atuar na funçáo profissional de planejar e promover a formaçáo continuada na rede estadual de educação de Santa Catarina, especificamente na Gerência Regional de Itajaí (GERED-Itajaí). Sabemos o quanto esse processo exige um conjunto de fatores e atores para poder ser trabalhado.

De acordo com a Proposta Curricular de Santa Catarina (PC/SC), de 1998, a Educação Ambiental (EA) é compreendida como um "processo educacional na gestão, no currículo, na formação continuada do docente/discente e comunidade" (SANTA CATARINA, 2014, p. 63).

Para dar sentido ao trabalho pedagógico do professor, as atividades em EA estão longe de se resumirem a vínculos com datas comemorativas, ou a campanhas e gincanas de coleta de resíduos, limpeza de rios e praias, necessárias, mas não suficientes. A intenção está em se promover práticas educativas bem mais conectadas às açóes coletivas, visando à construção de valores socioambientais, por meio de estratégias e açóes que promovam a apreensão de conhecimentos e outros saberes ambientais e socioculturais, bem como ao desenvolvimento de atitudes, habilidades e competências válidas para propor soluçóes ou minimizar os problemas socioambientais encontrados nas suas comunidades - de forma local e planetária.

Sem dúvida, estamos diante de uma série de desafios, cujos conceitos se apresentam, constantemente, em processos de construção. Se avaliarmos o simples fato de a temática da Educação Ambiental ser inserida nos currículos de nossas instituiçóes de ensino, vamos perceber, ao longo da história, o quanto esse campo já percorreu para que essa ação se concretizasse. Porém, mesmo com tal avanço, uma série de obstáculos se apresentam para a apreensão dos conceitos do saber ambiental, assim como para o desenvolvimento de estratégias de ambientalização curricular, como exige o desafio apresentado pelas Diretrizes Curriculares 
Nacionais para a Educação Ambiental (DCNEA) (BRASIL, CNE-MEC, 2012, Artigo 14, inciso V), no sentido de que as instituiçóes de ensino, de todos os níveis, passem pela transição de se tornarem espaços educadores sustentáveis, "integrando proposta curricular, gestão democrática, edificaçóes, tornando-as referências de sustentabilidade socioambiental.” (p. 5).

Por outro lado, por interferência das diferentes mídias, as verdadeiras causas da problemática socioambiental, entre elas o consumismo, provocam uma série de conflitos, uma vez que individualizam as questóes, resumindo-as, quase sempre, a ações pontuais como, por exemplo, a reciclagem/coleta seletiva; e a dualidade entre desenvolvimento sustentável/sustentabilidade - trabalhados equivocadamente como sinônimos, de sorte que, tanto para o professor quanto para o educando, chegam informaçóes desencontradas e confusóes conceituais que aportam, nas nossas escolas, sem a devida crítica e aprofundamento, faltando, às vezes, espaços formativos para a compreensão dos contextos ideológicos, políticos, culturais que envolvem a problemática socioambiental.

Nesse aspecto, Guimarães (2004) aborda como essencial a ruptura com as "armadilhas paradigmáticas" como uma primeira aposta para a formação dos professores educadores ambientais. Ressalta a necessidade de uma abordagem crítica na EA, voltada para uma prática transformadora "calcada em novos paradigmas, condiçóes materiais, posturas ético-políticas, entre outros." (p. 48).

No entanto, a inserção da dimensão da EA ainda é algo relativamente recente nos currículos de nossas Instituiçóes de Educação Superior (IES), e como uma temática a ser trabalhada nas escolas da Educação Básica. Assim, vivemos um momento de muitas preocupaçóes, quando se torna urgente a necessidade da formação continuada de professores educadores ambientais. É importante lembrar o principal marco legal da política de EA, a Resolução n. ${ }^{\circ} 2$, de junho de 2012, do Conselho Nacional de Educação (CNE), que criou as DCNEA, atendendo a uma antiga reivindicação dos educadores ambientais brasileiros. No que diz respeito à formação, destaca-se, nesse contexto, o artigo 19:

Os órgãos normativos e executivos dos sistemas de ensino devem articular-se entre si e com as universidades e demais instituiçôes formadoras de profissionais da educação, para que os cursos e programas de formaçáo inicial e continuada de professores, gestores, coordenadores, especialistas e outros profissionais que atuam na Educação Básica e na Superior capacitem para o desenvolvimento didático-pedagógico da dimensão da Educação Ambiental na sua atuação escolar e acadêmica. (BRASIL, 2012, p. 7, grifos dos autores). 
Ainda sobre essa articulação, a referida Resolução complementa, no seu $\$ 2^{\circ}$, o compromisso de as instituiçôes de ensino instituírem políticas permanentes que incentivem os professores e lhes deem condiçóes concretas de formação continuada, para que se efetivem os princípios e se atinjam os objetivos da EA.

A função técnica exercida, desde 2003, na GERED, como responsável pelas questôes relacionadas à formação continuada em EA na regiáo e por todas as questóes que requerem articulação entre as escolas e a Gerência, nos oportunizou integrar várias açóes no campo ambiental, como, por exemplo, a responsabilidade de representação no Comitê da Bacia Hidrográfica do Rio Itajaí e em grupos de trabalho em EA regionais e municipais.

Nesse contexto, a oportunidade se ampliou a partir do momento em que, pela necessidade de planejar as formaçóes continuadas, iniciou-se uma relação com os pesquisadores do Grupo de Pesquisa Educação, Estudos Ambientais e Sociedade (GEEAS), da Universidade do Vale de Itajaí (UNIVALI). A partir desse movimento, houve a continuidade das açóes na GERED para desenvolver uma pesquisa referente à formaçáo continuada do Programa Vamos Cuidar do Brasil nas Escolas (PVCBE), desenvolvido na região da Associação dos Municípios da Regiáo da Foz do Rio Itajaí (AMFRI), em Santa Catarina, no Programa de Pós-Graduação em Educação (PPGE) da UNIVALI.

Desse contexto também emergiu a proposta de pesquisa de tese de investigar os resultados dos encontros de formação com os educadores da rede pública estadual, de 2010 e 2012, que contaram com a participação do GEEAS e do PPGE-Univali, em parceria com instituiçóes como a Fundação do Meio Ambiente de Itajaí (FAMAI) e a Defesa Civil Regional.

Os temas aventados nas referidas formaçóes foram definidos pelas questōes pertinentes à sustentabilidade, aos espaços educadores sustentáveis e à formação, nas escolas, da Comissáo de Meio Ambiente e Qualidade de Vida na Escola (COM-VIDA). A escolha das temáticas estava relacionada com os movimentos dos programas federais e com o desenvolvimento dos estudos realizados pelo grupo de pesquisa GEEAS. Assim, para esse grupo:

A preocupação com a questáo da sustentabilidade socioambiental local e global, suas causas, conflitos, possibilidades de enfrentamento e análise das políticas públicas em EA nos sistemas de ensino, constitui um dos eixos de pesquisa e intervenção nos processos de formação continuada em EA do Grupo de Pesquisa Educação, Estudos Ambientais e Sociedade (GEEAS). (GUERRA et al., 2010, p. 199). 
Esse diálogo acerca das temáticas ambientais é um campo de conflitos e tensôes. Da mesma forma, a produção textual sobre a política pública em EA é algo distante da sua efetiva prática pedagógica nas escolas, ou seja, os programas da política governamental envolvem o interesse e as ideologias de um determinado grupo, que nem sempre dialoga com a realidade do cháo da escola, inviabilizando, a sua prática. Como afirma Libâneo (2006, p. 2), "frequentemente se observa que as políticas educacionais não estão a serviço das escolas e dos professores, não decorrem das necessidades e demandas efetivas da realidade das escolas e dos alunos." Guimarães (2004), por sua vez, ao refletir sobre a crise da EA, refere que ela se insere na crise dos paradigmas da modernidade e "ainda não se faz presente, de forma significativa, no chão-daescola, o que ressalta a necessidade de investigar os caminhos para uma efetiva práxis da EA." (op. cit., p. 117).

Nesse cenário de crise, dar atenção à realidade da escola é fundamental, pois é nesse universo que se busca

[...] superar a rejeição a construção de conhecimento não acadêmico (pesquisa), passa pela aceitação da validade de outros conhecimentos, mesmo que cientificamente não validados. Isto faz parte da transição paradigmática proposta por uma educação crítica. (GUIMARÃES et al., 2010, p.7).

Coerente com a proposta de uma educação ambiental crítica e transformadora, a intenção do estudo apresentado neste artigo foi refletir sobre os elementos essenciais que, na formação continuada, ampliem a inserção da educação ambiental na escola pública, na busca de processos formativos em EA, os quais contemplem uma sólida fundamentação filosófica, teórica e metodológica, na expectativa de que a escola não fique refém apenas do discurso de reprodução da sociedade capitalista e da propaganda das mídias, mas sim que se estabeleça um movimento de ação-reflexão-ação em toda a comunidade escolar, propiciando-lhe ser geradora de transformaçóes que estabeleçam uma cultura de promoçáo da sustentabilidade em todas as suas dimensóes.

Assim, os fundamentos e os diálogos de saberes perpassam pelos sentidos, de sorte que os educadores se sintam mobilizados e se permitam um olhar diferenciado para as questóes da realidade socioambiental, mantendo-se como parte e como todo do processo educacional, percebendo-se um Ser em desenvolvimento, envolvido com o ambiente onde está inserido e constantemente na busca de alternativas para minimizar os problemas encontrados. 


\section{Caminho metodológico}

A abordagem da pesquisa foi qualitativa, com um olhar para o vivido, uma vez que expor a própria experiência de gestão das formaçóes continuadas em EA, propiciou "reexaminar com um olhar novo as imagens fielmente amadas, tão solidamente fixadas na minha memória que já não sei se estou a recordar ou imaginar quando as reencontro em meus devaneios." (BACHELARD, 2013, p. 2).

Nesse sentido, o foco do estudo envolveu três formaçóes com a temática da sustentabilidade e escolas sustentáveis, desenvolvidas nos anos de 2010 e 2012, contando com a participação de 86 educadores de 31 escolas estaduais. A seleçáo dos educadores ocorreu por meio da análise documental de projetos, atas e relatórios das formações continuadas em EA da Gerência de Educação GEREDItajaí-SC. Após esse levantamento, verificamos a atuação desses educadores e a existência de práticas de Educação Ambiental nas respectivas escolas. Dos 86 cursistas, 33 estavam atuando nas escolas.

Para a seleção dos cursistas utilizou-se, como critério, a verificação do envolvimento de cada um com as práticas curriculares em EA, selecionandose nove professores (as) educadores ambientais para fazerem parte da pesquisa, compartilhando suas vivências e experiências de vida e de formação com o vivido da pesquisadora. Após a confirmação dos professores, foi realizada uma entrevista reflexiva com roteiro semiestruturado, o qual permitiu nortear o encontro e o diálogo para que pudéssemos ir conversando e refletindo sobre as questóes que eram desencadeadas, de forma que, nas análises das narrativas, fosse possível refletir sobre a fala de cada entrevistado, a fim de que houvesse compreensão e reflexão de ambas as partes, como também aprimoramento da fidedignidade.

Nesse sentido, em cada entrevista procuramos estabelecer, com cada entrevistado, uma relação aberta e respeitosa, construída pelo diálogo e pela interação constante, uma conversa para reconhecer o que cada educador (a) considerava fundamental nas formaçôes de professores para a EA.

Para resguardar o anonimato de cada educador (a), e inspirados pelo mergulho total no contexto de leituras, buscas, experiências e deslumbramentos com a poética do devaneio de Gaston Bachelard e sua simbologia dos quatro elementos - terra, água, fogo e ar, optamos em estabelecer, para cada um (a), um codinome de uma pedra preciosa ${ }^{3}$, pois assim é que percebemos a vida e a prática docente dos educadores (as) entrevistados. Como uma joia rara, cada

3 Cada professor educador ambiental recebeu um codinome: Esmeralda, Pérola, Ametista, Rubi, Ônix, Safira, Ágata, Cristal e Coral. 
um deles se diferencia, por sua especificidade e brilho identificados, observando cuidadosamente e lapidando suas falas sobre o contexto em que desenvolviam sua ação docente nas escolas.

As nove entrevistas realizadas foram gravadas com aparelho de áudio e transcritas em arquivos do Microsoft Word ${ }^{\text {}}$, realizando-se, em seguida, o processo de expressar a fala em forma de narrativas, preservando o sentido e as expressóes dos entrevistados.

\section{O diálogo com os professores educadores ambientais sobre os processos de formação}

A formação docente é um processo que precisa integrar seus conteúdos e práticas à reconstrução de valores éticos e à valorização da práxis refletida, o que exige do educador transformação pessoal e reflexão sobre a própria imagem e a autoimagem profissional (ARROYO, 2000).

Imbernón (2009, p. 106) comenta que a profunda mudança ocorre "quando a formação passar de um processo de 'atualizaçáo' a partir de cima, para se transformar num espaço de reflexão, formação e inovação para que o professorado aprenda." Nesse tipo de formação elencada pelo autor, o formador tem o papel de contribuir para a reflexão do docente e não somente pela sua técnica, para ajudálo a "descobrir a teoria implícita na prática docente", ou seja, valorizar aquilo que somos e nos constituímos, saber ouvir e ser reconhecido: "A formação move-se sempre entre a dialética de aprender e desaprender." (op. cit., p. 106).

Nesse sentido, a formaçáo colaborativa de Imbernón (2009) ensina a aproveitar a prática docente como principal veículo para desvendar os obstáculos, promover mudanças, denunciar aquilo que oprime e também promover a esperança da mudança e da transformação.

A escuta de quem está no processo educativo é fundamental. Assim, uma das educadoras entrevistadas, Esmeralda, revelou que, para uma formaçáo continuada em EA, seria necessário um tempo e um espaço com mais autonomia no recinto da escola. Para ela: "O projeto só vai dar certo se todos os professores pararem. Paramos no início do ano para discutir PPP e calendário. Mas não há tempo na escola para realizar uma formação continuada. A escola não possui autonomia para realizar estas ações." (Esmeralda).

Dar atençấo à sugestão dessa prática que persistiu nos relatos dos professores educadores é perceber que as mudanças devem ser realizadas pelo sistema macro de ensino. Um claro exemplo é que, geralmente, no início do ano letivo, o quadro dos educadores não está totalmente preenchido, dificultando a integração e o 
desenvolvimento pedagógico do grupo escolar. O pouco tempo disponível não permite um diálogo mais profundo para o estudo e a escolha da temática da formação, bem como a elaboração de uma proposta pedagógica coletiva. Que autonomia a escola possui nesse aspecto? De que tempo dispóe para planejar? São questóes reais traduzidas pela voz de Esmeralda, mas subjacentes aos depoimentos de todos os demais educadores.

Podemos ampliar essa questáo na perspectiva desse tempo/espaço de envolver uma formaçáo que reflita não somente o contexto vivido da escola, como nos apresenta Tristão (2003), quando afirma que: "o conhecimento hoje se processa para além do espaço/tempo da escola, as práticas educativas vêm absorvendo princípios, valores e produzindo sentidos sobre a Educaçáo Ambiental.” Segundo a autora, nos estabelecemos e nos relacionamos em vários contextos. $\mathrm{O}$ nosso vivido vai além do espaço escolar e está presente nas açóes vivenciadas no decorrer da vida. Por isso, a autora ainda se apoia na acepção de Spink (1998) sobre a perspectiva temporal dos três tempos presentes no contexto discursivo associados, aqui, aos contextos formadores, cujos tempos ela explica da seguinte forma:

Tempo curto refere-se às interaçôes do dia-a-dia, que têm por foco a funcionalidade das representaçóes e a dialogia - relaciono com o dia-a-dia da escola; tempo vivido, que abrange os processos de socializaçáo, o local de pertença de determinados grupos sociais, a ressignificação dos conteúdos históricos - articulo com as práticas pedagógicas e com a própria história pessoal no curso de vida das pessoas; tempo longo é o acúmulo de conhecimento produzindo a memória coletiva, o imaginário social, ou seja, uma concepção de natureza presente no passado e ressignificada no presente formaria os conteúdos sobre Educação Ambiental. No tempo longo, os repertórios disponíveis são moldados pelas contingências sociais, isto é, pelas redes de significados que constituem o espaço dos conhecimentos produzidos. (TRISTÃO, 2003 p. 25, grifos dos autores).

A explicação da autora sobre a importância dos espaços/tempos da EA nos remete, novamente, a Imbernón (2009), o qual, por sua vez, considera a existência de uma proposta permanente de formação, no sentido de superar alguns desses obstáculos dos espaços-tempos da escola, como destacados por Esmeralda. Para isso, seria necessário:

- a possibilidade de uma maior autonomia na formaçáo com a intervenção direta do professorado;

- partir dos projetos das escolas para que o professorado 
decida qual formação de que necessita para levar adiante o desenho, a colocaçáo em prática e a avaliaçáo do projeto. (IMBERNÓN, 2009, p. 39).

O autor citado se refere, assim, a "um processo formativo que possibilite o estudo da vida". Essa formação visualizada como processo precisa acontecer com base na reflexão do educador sobre sua própria prática, pois é nesse ambiente que emergem os obstáculos e aparecem tanto as dificuldades, como as potencialidades. Por isso, a importância de se constituir uma rede de saberes na qual os professores possam trocar experiências e aumentar a comunicaçáo entre os pares para pensar acerca de sua prática educativa e compartilhar acertos e erros.

Eu penso, deve ter oficinas, a prática, a troca de relatos de experiências com os professores, e inclusive a partir desse momento detectar as falhas as dificuldades no processo de ensino aprendizagem (Ametista). Sim acho bem importante este enfoque, é a relação da açáo/reflexão, a partir do momento que você vê um problema, discute e possibilita refletir para agir com a prática percebida (Pesquisadora). E eu já fiz essa reflexão no conselho escolar, reuni a APP e o Conselho Escolar. Comentei sobre o aprendi com relação ao agrotóxico. E dali foi retirado à ação deles próprios, pois normalmente aqui nas casas têm uma horta, um pomar, isso eu acho importante, trazer a comunidade e mostrar para a comunidade ou para alguns pais que participam junto do problema, que é o agrotóxico (Ametista).

Esse relato de Ametista expóe um elemento importante a ser trabalhado na formação, o qual vem persistindo nas orientações encaminhadas na pesquisa de Guerra (2001) e, nos últimos anos, ampliadas pelo grupo do GEEAS em suas pesquisas relacionadas ao processo de formaçáo em EA, no sentido de focar na metodologia adequada para o campo educacional, a qual envolva a dimensão do conteúdo escolar (conhecimentos, habilidades e competências, atitudes e valores) para inserir a dimensão ambiental no currículo. Segundo o autor, essa metodologia incorpora o saber fazer, o saber ser e o saber conviver (op. cit., p. 140, grifos dos autores). Tal proposta integra as seguintes dimensóes: cognitiva, metodológica, afetiva e ecosófica, explicadas da seguinte forma.

A dimensão cognitiva (conhecimentos e saberes); metodológica (habilidades e competências); afetiva (sensibilização para mudança e reflexão sobre atitudes, valores éticos e estéticos, 
as relaçóes inter e intrapessoais; e a dimensáo ecosófica (GUATTARI, 1994), ou da ética e cidadania, intimamente relacionada à ação e reflexão sobre a ação (a práxis de Paulo Freire) individual e junto aos grupos sociais, envolvidos no processo de aprendizagem em EA [educação ambiental] (GUERRA; LIMA, 2004, p. 12, grifos dos autores).

É importante compreender que as referidas dimensões estão interligadas e, ao mesmo tempo, são interdependentes, em movimento constante para alcançar um processo efetivo de formação docente em Educação Ambiental. Para o autor, "todo esse processo gera um saber-poder de mudança que nos conduziria a novas formas de aprender e saber fazer, e também de saber ser e de conviver com os outros." (GUERRA, 2001, p. 147).

Hoje, os processos formativos de EA têm sua base epistemológica alicerçada em conhecimentos e no diálogo dos saberes ambientais que integram possibilidades de ser, sentir, conhecer e experienciar, permitindo um pensar e um agir dos professores educadores ambientais "por meio da sensibilizaçáo, informação, contextualização e ação reflexivo-crítica" dos problemas socioambientais." (TAVARES; BRANDÁO; SCHMIDT, 2009, p. 193). Os autores apontam que uma EA baseada na ética e na estética dos sujeitos colabora para uma ação social responsável, ampliando o modo ver e atuar na vida.

Desse modo, e retomando também Tristão (2003), essa formação passa por tempos e espaços diferenciados, mas isso não ocorre de uma forma linear, uma vez que necessita de um olhar atento para sua constituição, com o cuidado de permitir momentos de construçáo coletiva entre os educadores e seu formador ou seu grupo de estudos. E partir, sempre, das práticas educativas, da sua experiência, conhecer a história dos envolvidos e buscar os elos entre ambas, compartilhar os problemas existentes e, coletivamente, buscar possíveis soluçóes por meio da construção de saberes. Além disso, essa formação é um movimento importante que mobiliza o individual para transformar os pensamentos, as atitudes e os valores com "aprofundamento no modo como enxergamos a Vida" (TAVARES; BRANDÁO; SCHMIDT, 2009, p. 181).

Nessa forma de pensar uma formação de EA, Pérola relatou a necessidade de cinco momentos: sensibilização; conhecimento teórico; vivência prática; plano de ação e avaliação.

No primeiro momento, sensibilização, sensibilizar os alunos, os professores que estariam fazendo parte dessa formação. Segundo, penso que eles têm que conhecer o histórico da educação ambiental, e perceber que nós fazemos parte do 
contexto, que nós não estamos fora desse contexto, que nós somos, é, parte. Terceiro, eu penso que uma saída de campo, com os colegas do curso, pra vivenciar um projeto, para vivenciar. Fazer parte do processo, vivenciar. Uma ação pode ser numa praia, num parque, dentro da escola, enfim, mas vivenciar e, em seguida, acho que nós temos que avaliar algum programa de educação ambiental, depois levantar literatura, procurar autores que respaldem o que a gente pensa, e depois desenvolver um plano de ação na escola, um projeto na escola, pra estar na pele, e realizar as atividades de educação ambiental na escola, e avaliar também o que a gente está fazendo lá. (Pérola).

Para Pérola, são vários os elementos que podem estar presentes na formação. A sensibilização já foi destacada por ela, desde o início de seus relatos, e a aponta como uma das potencialidades possibilitadas pela formação continuada de 2010. Assim, prioriza seus primeiros passos na direçấo de estabelecer uma relaçâo de confiança, humana e verdadeira com o educando, para que ele perceba o espaço onde vive e as relaçóes envolvidas entre eu, o outro e o ambiente. "Acreditamos que a relaçáo do ser humano com o meio deve ser conquistada através da sensibilidade, da percepção e da reflexão crítica." (TAVARES; BRANDÁO; SCHMIDT, 2009, p. 185). Pérola sugere, ainda, que a formaçáo seja exercida no grupo, envolvendo fundamentos teóricos, práticos, avaliação e reflexão das açóes pactuadas pelo e no grupo.

Os autores enfatizam que há uma grande propagaçáo da Educaçáo Ambiental no processo educacional, porém essa ação educativa contém fragilidades na prática pedagógica. $\mathrm{Na}$ maioria das vezes, o professor preocupa-se com a problemática ambiental de seu entorno, discute e mobiliza, entretanto não consegue uma transformação da realidade.

Nossa prática como formadores em EA converge com as ideias dos autores e autoras até aqui mencionados, destacando-se a de Guimarães (2004), quando afirma que os professores, apesar de sensibilizados e mobilizados e de terem inserido a dimensão ambiental em suas práticas educativas, não conseguem ir além de uma proposta de educação conservadora ${ }^{4}$ que permita sair dos "questionamentos das práticas escolares dominantes" (p. 120). Assim,

4 "Esses professores foram ou estão sendo formados, em sua maioria, na mesma perspectiva conservadora de educação que reproduz a e se reproduz na armadilha paradigmática. Ou seja, dada uma compreensão de mundo moldada pela racionalidade, fazer diferente do caminho único prescrito por essa racionalidade, efetivando-se a hegemonia." (GUIMARÃES, 2004, p. 124). 
concordamos com o autor quando indica, no fazer pedagógico, um novo pensar voltado à "transformaçáo de um mundo ambientalmente sustentável" (GUIMARÁES, 2004, p. 120), o que nos remete, também, à necessidade de uma reflexão crítica como força propulsora “... é a ruptura radical com o colonialismo e a recusa igualmente radical ao neocolonialismo" (FREIRE, 1992, p. 91). Para essa ruptura com transformaçóes significativas, é necessária a intervenção do que Guimarães (2004, p.133) chama de "sinergia de um movimento em conjunto". Segundo ele, não adianta uma ação individual ou intervenções pontuais; a ação deve ser conjunta, pois é a força do coletivo que forma a sinergia, "uma resistência como uma contra correnteza" (p. 132).

Uma forma de resistência, de acordo com o autor, é a formação de dinamizadores de ambientes educativos (educador ambiental) que agem no processo de intervenção, motivados pela reflexão crítica das dinâmicas da realidade socioambiental. Para o educador ambiental ser esse dinamizador, é fundamental trabalhar uma liderança que permita transitar e movimentar-se no conjunto coletivo de resistência.

Esse educador ambiental, como liderança, precisa compreender o contexto da realidade socioambiental em que vai intervir. Sugere, o autor, que, inicialmente, se pode realizar o diagnóstico socioambiental conhecendo a realidade, suas condições, valores, hábitos, atitudes dominantes exercidas pelo grupo, para, depois disso, trabalhar os conflitos, problematizar e movimentar a comunidade para a construçáo da sustentabilidade socioambiental. Esse educador é um ser humano que precisa ser percebido em sua plenitude e ser valorizado, não somente como um ser que pensa, mas que também sente, vive em grupo e se relaciona um com outro e com o mundo, pois a "educação se dá na relação" (p. 143). Por isso, a importância de uma autoformação eclética, destacada pelo autor: transitar pelas ciências, pelas artes, pela filosofia e ser um interlocutor na articulação dos diferentes saberes.

A fala de Rubi nos traz elementos para compreender esse processo dialético de formação pela práxis:

Acho que tem que mostrar para os professores que dá para trabalhar e ver o resultado. Talvez trazer modelos que deram resultados no passado, que daria para implantar, para o professor ver que dá certo. Assim, não ficar só na parte teórica, partir para a prática... Precisamos de muita parceria. Poderiam vir estagiários da universidade na escola, para atender toda a escola, assim todos os professores poderiam atuar. Precisamos de empresas nos apoiando, antes a Petrobrás e a Malwee muito ajudavam nos trabalhos, hoje não conseguimos mais estas forças. (Rubi). 
Nesse sentido, Rubi visualizou uma formação a partir do que já se realizou, de uma práxis, de uma ação, sugerindo parcerias entre as secretarias de educação, universidades e empresas, visualizando e ampliando o processo formativo não apenas com essas questóes práticas ou modelos do passado. Temos o desafio de romper com a armadilha paradigmática para a construção de um ambiente educativo que propicie um movimento em conjunto, o qual visualize um trabalho de resistência contra atividades individuais ou açóes pontuais, sem a devida reflexáo a respeito das causas dos problemas socioambientais.

$R u b i$ apontou a parceria com a universidade e com a presença de estagiários no contexto escolar para promover diálogos, trocas de experiências e pesquisas que movimentem a escola. Essa parceria já foi destacada por Guerra e Orsi (2008), a partir dos estudos de Leme (2006, p. 41), como uma possibilidade de intercâmbio "principalmente na sistematização e divulgação dos saberes produzido a partir das experiências".

Por seu turno, Ônix também sugeriu uma formação entre as escolas com intercâmbios, além da iniciativa de instauração de uma política estadual de formação continuada.

Mas com os professores seria uma coisa diferente, fazer um intercâmbio das formaçóes que acontecem no início e do meio do ano entre as escolas, para comparar outras ideias, para fazer um encontro dos professores, não só das mesmas disciplinas, mas fazer um encontro. Para a formação em educação ambiental para os professores, como ela não é uma disciplina e nem um curso superior. Então, deveria talvez ser disponibilizado pelo governo estadual uma pós graduação em educação ambiental para todos os professores, principalmente os que não são das áreas de ciências biológicas e geografia, para aplicarem a EA na sua disciplina. (Ônix).

Ele abordou uma formação baseada na troca de experiências, como também uma possibilidade de permitir, ao educador, conhecer outros contextos, desde os problemas socioambientais, até os encantamentos pelas realidades vividas, uma ampliação dos aspectos geográficos, sociais, culturais e ambientais das escolas, salientando não se tratar de encontros por áreas, mas da reunião de todos os educadores, de forma a aumentar o diálogo e estreitar suas relaçóes para visualizarem as potencialidades e os entraves nas práticas pedagógicas. Em resumo, como salienta Imbernón (2009), criar estruturas de redes organizativas 
[...] que permitam um processo de comunicação entre os pares e intercâmbio de experiências para possibilitar a atualização em todos os campos de intervenção educativa e aumentar a comunicação entre o professorado para refletir sobre a prática educativa mediante a análise da realidade educacional, a leitura pausada, o intercâmbio de experiência, os sentimentos sobre o que acontece, a observação mútua, os relatos de vida profissional, os acertos e os erros... que possibilitam a compreensão, a interpretação e a intervenção sobre a prática. (op. cit., p. 40-41).

A mesma pedra preciosa também teve o cuidado e a intencionalidade de apontar a necessidade de formação continuada por meio de especializaçóes, pois a EA, recentemente, está nos currículos das IES, revelando a precariedade existente no acesso desse conhecimento. Por isso, é fundamental um investimento nas Políticas Públicas de EA, por meio dos programas para o fortalecimento e a institucionalização da EA, para a qual o processo de ambientalização pode ser um caminho.

Porém, mesmo que as açôes de formação e aperfeiçoamento docente tenham sido incorporadas à política nacional (como o caso do Programa Nacional de Formação de Educadores (as) Ambientais - ProFEA5) e estadual (Programa Estadual de EA - ProEEA), e aos cursos de formaçáo continuada oferecidos, infelizmente ainda não se tornou efetiva, o que coloca em questão as fragilidades presentes no sistema educacional, reforçando a tese de que somente a existência de boas leis e bons programas não garante a sua aplicabilidade e as transformaçóes que a Educação e a realidade exigem.

Assim, concluiu-se que sair do papel para a realidade e da teoria para a prática ainda é um desafio. Por isso, é fundamental pensar na formação permanente dos educadores aliada às políticas da carreira profissional, como salienta Imbernón (2009, p. 42-43):

A formação por si só consegue muito pouco se não estiver aliada a mudanças do contexto, da organizaçáo, de gestão e de relaçôes de poder entre os professores. O tão mencionado desenvolvimento profissional náo recai na formação, mas em diversos componentes que se dão conjuntamente na prática de trabalho do ensino.

5 Ver Caderno do ProFEA, em <http://www.mma.gov.br/estruturas/educamb/_arquivos/dt_08.pdf>. Acesso em: 01 set. 2016. 
Safira, no seu relato, abordou a importância da avaliaçáo como um processo que precisa estar presente nesse caminho.

Tem que fazer um encontro, tem que haver cobrança. A pessoa que estava encarregada de ir no curso tem que promover açóes. E assim fez tudo que tu for trabalhar, a questão da água, questão dos resíduos, seja lá o que for trabalhado, a pessoa que entenda do assunto, né, que saiba daquilo que tá falando, que possa passar pra gente segurança, e ó, é assim e assim que acontece, é por isso e por isso, pra gente ter uma noção. A gente não conhece, muitas vezes a gente é leigo no assunto, né. Sabe aquilo que os livros trazem e aquilo que tu procuras saber. E depois não ficar só ali, é um curso de uma semana, vou ficar só estudando gráfico e tal, não, agora a gente vai, entấo é a questão da água, então vamos fazer uma visita na SEMASA. Como é que isso funciona? Porque tem professor que não sabe por onde que passa, sabe que tem um filtro de decantação, de filtração disso e aquilo, mas não vivencia, não observa, não olha. Retornar para o curso, avaliar as açôes. (Safira).

Dessa forma, para Safira, há uma necessidade de cobrança com relação aos compromissos assumidos pelos professores que realizam as formaçóes. Faz-se necessário criar mecanismos para rever essa atitude, como nos aponta Imbernón (2009, p. 42), para o "desenvolvimento de uma cultura colaborativa no centro (análise, experiência e avaliação coletivamente) e de uma maior profissionalização docente através de projetos conjuntos."

Essa é uma cultura ainda ausente em nosso contexto escolar, o que gera conflitos e açóes isoladas de alguns professores educadores ambientais e nos faz refletir sobre a necessidade de repensar a formação continuada para formar formadores em EA. Isso pode ser construído na ótica apontada por Sauvé (2003), no documento Perspectivas curriculares para la formación de formadores en educación ambiental, um projeto de investigação-desenvolvimento colaborativo de cooperaçáo universitária internacional ${ }^{6}$, o qual apresenta um conjunto de fundamentos teóricos e curriculares para a Educação Ambiental, na perspectiva

6 Trata-se do Proyecto de Cooperación Universitaria Internacional Edamaz (Educación ambiental en Amazonia), outro marco do projeto ERE-Francophonie, que reuniu coparticipantes institucionais de cinco países da Francofonia, do Norte e do Sul (SAUVÉ, 2003, p. 2, tradução nossa). 
de uma formação de integração, investigação e intervenção que nos conduza a refletir e agir a respeito da problemática socioambiental, além do que temos e do que podemos melhorar no espaço educativo. Segundo a autora:

Encontra-se aqui uma preocupação em integrar a formaçáo, a pesquisa e a intervençáo. Trata-se de promover uma formação reflexiva na intervenção. A intervenção, por um lado, tanto é ambiental (um ato ou um projeto para o meio ambiente) e educativa (um processo de desenvolvimento pessoal e social). Por um lado, ela se inspira no campo teórico e prático da açáo ambiental e da açáo pedagógica; por outro lado, ela contribui para enriquecer estes últimos com o aporte dos participantes. (SAUVÉ, 2003, p. 11, tradução e grifos dos autores).

Esse programa possibilita o acompanhamento dos professores para esclarecer o conceito de Educação Ambiental, de acordo com atividades práticas para refletir as temáticas abordadas, em uma perspectiva crítica. Nesse sentido, os docentes exercitam sua argumentação com a sua própria concepção, nas intervençóes que fazem no decorrer da formação.

Para contemplar as atividades, o programa define alguns princípios da formaçáo continuada em EA, os quais, em nossa leitura, se aproximam do processo educativo e das metodologias empregadas nas formaçôes da GERED, inspiradas nos pressupostos epistemológicos, filosóficos e metodológicos estudados e aprofundados em nossa trajetória no grupo de pesquisa do GEEAS-Univali, bem como das contribuiçóes para a formaçáo de educadores ambientais dentro de uma perspectiva crítica.

Como procuramos demonstrar neste artigo, essa comunidade de aprendizagem (ORELLANA, 2002), formada nos processos desenvolvidos pela GERED-Itajaí, de 2010 a 2012, com o suporte das abordagens propostas por Guerra (2001), Tristão (2001), Guimarães (2004), Sauvé (2003) e Freire (1981-1986), direcionam e convergem para o planejamento de um processo de formação continuada em Educação Ambiental que se caracteriza pelo diálogo como referência para a abordagem das diferentes dimensóes do processo educativo em EA: cognitiva, metodológica e afetiva.

A partir do movimento exercitado nesta pesquisa, é que apresentamos na Figura 1 uma síntese dos elementos constituintes de um processo de formação continuada de professores educadores ambientais. A construção dessa síntese representa tanto os fundamentos filosóficos e epistemológicos que dimensionam as práticas em EA, e com os quais dialogamos na pesquisa, quanto o aprendizado dos conhecimentos, saberes, valores e experiências resultantes do diálogo realizado 
entre a pesquisadora e as pedras preciosas, participantes desta pesquisa.

Figura 1: Representação dos elementos constituintes de um processo de formação continuada em EA

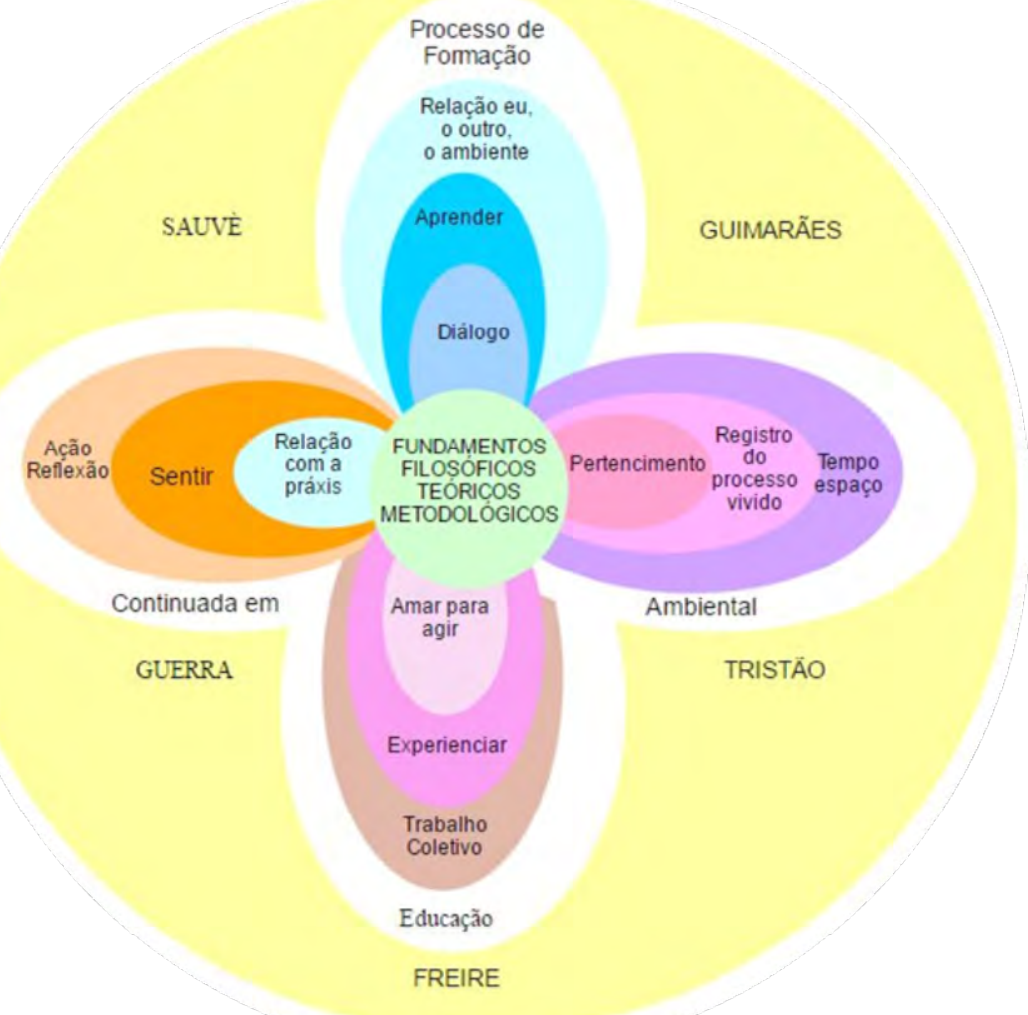

Fonte: (ORSI, 2016, p. 185)

A representação da Figura 1, sobre os elementos constituintes da formação do professor educador ambiental, pode ser compreendida como a síntese do caminhar ao longo deste estudo e da nossa formação como pesquisadores. As pétalas da mandala podem ser visualizadas em movimento circular, uma dança de ritmos e cores, em que cada pétala faz parte de um todo que se complementa.

A mandala incorpora elementos apresentados por Guerra (2001) - sobre a dimensão ambiental no currículo, permeada pela ênfase no estímulo à percepçáo e à educação em valores, bem como as proposiçóes de uma formaçáo do educador ambiental crítico, que possibilitam um movimento dialético de transformaçóes simultâneas do indivíduo e da sociedade, utilizando o diálogo como o instrumento principal para uma conexão com a realidade, que possibilite ação e reflexão, uma 
"práxis autêntica”, nas palavras de Freire (1981, p. 21).

Segundo Guimarães (2004), essa reflexão sobre a práxis consiste no caminho teórico-metodológico para compreender os sentidos, os limites, as carências e as rupturas, com o objetivo de "transformaçóes significativas" buscando amenizar os problemas socioambientais e promover um ambiente sustentável, cujos sentidos superem as fragilidades na prática pedagógica, ou seja, que a formação permita a construção de um fazer pedagógico direcionado à transformação da pessoa, do ambiente local e global, para tornar realidade o movimento de transição da escola para um espaço educador sustentável, a partir de um tempo/espaço impregnado de sentidos sustentáveis (TRISTÃO, 2003).

Nesse sentido, a mandala sinaliza, também, que a escola pode ser um ambiente de vida, de partilhar experiências em todos os contextos, possibilitando que a EA exerça seu papel e seu compromisso como uma dimensão essencial da Educação (SAUVÉ, 2005). Desse modo, se caracteriza por uma intensa inter-relação entre o eu o outro, a sociedade e o ambiente, em um movimento que transforma, reconhece e compreende os problemas socioambientais, buscando a formas de agir coletivamente em prol de uma sociedade sustentável e justa.

\section{Considerações Finais}

O percurso do presente estudo permitiu o exercício de percepção, leitura e construção de uma mandala de formação em EA que nos remete ao movimento que, em essência, é a formação por excelência do educador que valoriza o Ser, o sentir e o agir, não como gavetas desconectadas, mas como um movimento contínuo de ação-reflexão-ação, ou seja, de fazer-refazer caminhos, pensarrepensar outros modos de reencantar a Educaçáo.

A escolha pela representaçâo circular da mandala dialoga com todo o percurso da pesquisa realizada, abrindo a possibilidade de outros processos formativos possíveis, que pensem o ser como uma totalidade e a Educação Ambiental como uma escolha pelo cuidado com nossa Casa-Comum, que compartilhamos com outras tantas formas de vida ao universo que pertencemos.

Assim, propor uma proposta de formação continuada em EA, é permitirse Ser, olhar para seu interior e visualizar suas potencialidades realizadas no seu

7 Mauro Guimarães destaca que essas transformaçốes se referem à inserção de novas relaçôes na realidade, com a intencionalidade de ruptura das relações de dominação e exploração nas práticas individuais e coletivas, tornando-se uma causa de luta política, de vida e vivida (GUIMARÃES, palestra em 09 ago. 2016). 
mundo vivido e dialogar sobre suas práticas educativas e sociais.

O registro em forma de narrativa das pedras preciosas foi uma oportunidade de poder partilhar as suas e as nossas vivências, desenvolver um olhar reflexivo sobre si e sobre o outro, fazer uma releitura de sua própria vida vivida, além de poder apresentar ao outro suas experiências, seus acertos e também algumas dificuldades e obstáculos. Esse caminhar demonstrou que é possível romper com um sistema linear de processos formativos de recepçáo e transmissão de conhecimento isolado, e que é desejável a busca pelo trabalho coletivo, pela troca de saberes, mediado pelo diálogo, constituindo o fundamento de uma formação continuada que valoriza a diversidade epistemológica.

Esse movimento de perceber-se, sentir e registrar a sua práxis se intensifica com os estudos da realidade por meio de diagnósticos, visualizando os problemas ambientais como também as potencialidades locais, em um movimento coletivo para buscar alternativas para amenizar a crise ambiental. Por isso, entende-se a importância de contextualizar, conhecer e se apropriar de conceitos estruturantes do saber ambiental, por meio de atividades de intervenção que propiciem a ação/ reflexão na incorporação de práticas educativas que gerem mudanças individuais e coletivas que expressam a tão desejada transição das escolas para espaços educadores sustentáveis.

Assim, a fundamentação filosófica, teórica e metodológica delineia-se a partir do diálogo das necessidades, um movimento construído no processo que permita uma interação e uma construçáo coletiva para refinar o discurso/conhecimento/ metodologia, assim como resultado visualizar, a partir das potencialidades desse processo, práticas pedagógicas e sociais que transformem significativamente a sociedade de consumo.

Um fator importante nesse percurso é a maneira como vivenciamos o espaço/ tempo do aqui e agora, que revela que estarmos conectados com nosso sentir, com a nossa presença táo importante no mundo, no planeta, "é estar ancorado na realidade concreta” (SAUVÉ, 2016, p.291). Resulta, então, essa conexão de experienciar, de sentir, de não anestesiar nossa mente e o nosso corpo, de perceber nossos dilemas, as sensaçóes e o prazer pela vida, a partir da interação de nosso movimento com o ambiente, a conexão com o cosmos. Essa conexão poderá ser desencadeada por atividades que mobilizem, tanto a cogniçáo, quanto os sentidos, como a música e a dança, que permitem uma extensão de percepção, não de um tempo linear, mas para sensação do aqui e agora da minha condição de Ser e estar nesse mundo vivido.

Pertencer a esse cosmos é religar a partir de sentimentos de amor e cuidado com a vida nosso planeta, fundamentais no processo formativo. De acordo com Oliveira, Pereira e Viana (2008), representam as açóes conosco mesmo, 
com o próximo e com a natureza, ou ainda, com as três esferas de interação do desenvolvimento pessoal e social (SAUVÉ, 2005), como um chamado para nossa atuação de responsabilidade. Enfim, estamos em relação eu, outro e o ambiente, por isso há de reconhecer a importância da ética dos valores, da nossa açáo comprometida nesse tripé de respeito e solidariedade com nossa Casa-Comum.

Com a metáfora da mandala, esperamos construir trajetos, navegar não solitária, mas coletivamente, num contínuo movimento de pensar o espaço da formaçáo como fonte, e o espaço escolar como aquele que se constrói com alegria, ousadia e, por vezes, com a necessidade de uma grande porção de poesia, arte, razão, valores, saberes, enfim, no processo vivido.

\section{Referências}

ARROYO, M. Ciclos de Desenvolvimento Humano e Formação de Educadores. Educaçáo \& Sociedade, ano XX, n. 68, p. 143-162, dez/1999.

BACHELARD, G. A Terra e os Devaneios da Vontade: Ensaio Sobre a Imaginação das Forças. 4. ed. Sáo Paulo: Martins Fontes, 2013.

BRASIL. Resolução no 2, de 15 de junho de 2012. Estabelece as Diretrizes Curriculares Nacionais para a Educação Ambiental. Diário Oficial [da] República Federativa do Brasil, Brasília, DF, 18 jun. 2012. Seção 1, 70 p.

FREIRE, P. A Pedagogia do Oprimido. Rio de Janeiro: Paz e Terra, 1981.

. Pedagogia da esperança. Rio de Janeiro: Paz e Terra, 1992.

GUERRA, A. F. S. Diário de bordo: navegando em um ambiente de aprendizagem cooperativa para educação ambiental. 2001, Florianópolis, 336 f. Tese (Doutorado em Engenharia de Produção) - Universidade Federal de Santa Catarina - UFSC.

SPINK, M. J. Práticas discursivas e produçáo de sentidos no cotidiano: aproximaçóes teóricas e metodológicas. São Paulo: Cortez, 1999.

; LIMA, M. B. A. Refletindo sobre a inserção da dimensão ambiental na formação docente. In: ZAKREZVSKI, S. B.; BARCELOS, V. Educaçáo Ambiental e compromisso social: Pensamentos e açóes. Erechim, RS: EdiFAPES, 2004, p. 41-61.

FIGUEIREDO, M. L. Sustentabilidade ou Desenvolvimento Sustentável? Da ambiguidade dos conceitos à prática em Educação Ambiental. In: GUERRA, A. F. S.; FIGUEIREDO, M. L. Sustentabilidades em diálogos. Itajaí: Univali, 2010, p. 191-212. 
; ORSI, R. F. M. Tendências, abordagens e caminhos trilhados no processo de formação continuada em educação ambiental. Revista Eletrônica do Mestrado em Educaçáo Ambiental, v. especial, p. 18-45, dez. 2008. Disponível em: < https://www.seer.furg.br/remea/article/view/3386/2032>. Acesso em: 17 jul. 2016.

GUIMARÁES, M. A formaçáo de educadores ambientais. Campinas: Papirus, 2004.

et al. A pesquisa na formação do Educador Ambiental. Ensino, Saúde e Ambiente, v. 3, p. 3, 2010.

IMBERNÓN, F. Formaçáo permanente do professorado: novas tendências. São Paulo: Cortez, 2009.

LEME, T. N. Os conhecimentos práticos dos professores: (re) abrindo caminhos para a educação ambiental na escola. São Paulo: Annablume, 2006.

LIBÂNEO, J. C. Sistema de ensino, escola, sala de aula: onde se produz a qualidade das aprendizagens. In: LOPES, A. C.; MACEDO, E. (Orgs.). Políticas de currículo em múltiplos contextos. São Paulo: Cortez, 2006, p.1-21.

ORSI, R. F. M. A formaçáo continuada do Programa Vamos Cuidar do Brasil com as escolas na regiáo da Amfri em Santa Catarina. 2008, Itajaí, 127 f. Dissertação (Mestrado em Educação), Universidade do Vale do Itajaí - UNIVAL.

. O movimento da formaçáo continuada em educaçáo ambiental: experiências vividas. 2016, 211 f. Tese. (Doutorado em Educação) - Universidade do Vale do Itajaí- UNIVALI.

SANTA CATARINA. Secretaria de Estado da Educação. Proposta Curricular: formação integral na Educação Básica, Secretaria de Estado da Educação, 2014, p. 63-66.

SAUVÉ, L. Perspectivas curriculares para la formación de formadores en educación ambiental. In: Foro Nacional sobre la incorporación de la perspectiva Ambiental en la Formación Tecnica Profesional, 1., San Luis Potosí, 9 a 13 jun. 2003. Anais..., San Luis Potosí, 2003.

. Educação Ambiental: possibilidades e limitaçóes. Revista Educaçáo e Pesquisa. São Paulo, v.31, n.2, p. 317-322, maio/ago. 2005.

TAVARES, C. M. S., BRANDAO, C. M. M., SCHMIDT, E. B. Estética e Educação Ambiental no paradigma da complexidade. Pesquisa em Educaçáo Ambiental, v. 4, n. 1, p. 177-193, 2009. 
TRISTÃO, M. Os sentidos da educaçáo ambiental nos contextos de formação de professores/as. In: REUNIÃO ANUAL DA ANPED, 24, Caxambu, 2001. Anais... Rio de Janeiro: Anped, 2001.

Contextos vividos e tecidos nos espaços/tempos da educaçáo ambiental.

Revista de Educaçáo Pública, UFMT, v. 12, n. 21, p. 25-41, 2003. 


\section{História da Educação}





\title{
Cartas Sororales entre de dos mujeres intelectuales: Palma Guillen y Gabriela Mistral
}

\author{
Sorority letters between two intellectual women: \\ Palma Guillén and Gabriela Mistral
}

Oresta LÓPEZ PÉREZ1

\begin{abstract}
Resumen
En el presente trabajo hacemos una inmersión al tejido epistolar como la figuración de la sororidad entre dos grandes maestras latinoamericanas: la escritora chilena y premio Nobel Gabriela Mistral y Palma Guillén, maestra mexicana, diplomática y escritora. Una relación que inició en 1922 y duró hasta la muerte de Gabriela Mistral en 1957. Especialmente se revisará el intercambio epistolar entre 1942 y 1957, (ZIEGERS, 2011), para posicionar los alcances, disidencias y aportes de la comunicación entre mujeres, como representación sororal. Las fuentes son las cartas tejidas en la comunicación que en esta época podían construir dos grandes amigas, enfrentando a su manera las distancias, la desesperación, el dolor personal y las percepciones del mundo en guerra que vivieron.
\end{abstract}

Palavras-clave: Sororidad. Género. Escritura capitular. Educación.
Abstract

Sorority letters between two intellectual women: Palma Guillén and Gabriela Mistral In the present work an immersion in the epistolary exchange is offered as the figuration of the sorority between two great Latin American women intellectual: the Chilean woman writer and winner of the Nobel prize Gabriela Mistral, and Palma Guillén, woman diplomat and Mexican writer. A relationship that began in 1922 and lasted until the death of Gabriela Mistral in 1957. I analyze the epistolary exchange between 1942 and 1957 (Ziegers, 2011) looking for cognitive possibilities of sororal representation, to know the meanings, dissidences and contributions about communication between women. The sources are the text woven in the communication between two great women friends who face in their own way the distances, the desperation, the personal pain and the perceptions of the world in the wars they lived.

Keywords: Sorority. Gender. Capitular writing. Education.

1 Dra. en Ciencias Sociales, Profesora Investigadora de El Colegio de San Luis, Centro Público de Investigación del Consejo Nacional de Ciencia y Tecnología de México. Coordinadora del Laboratorio de Investigación: Género Interculturalidad y Derechos Humanos LIGIDH-COLSAN www.colsan.edu.mx tel. (52)-444-8110101 ext.6112. E-mail: <oresta.lopez@colsan.edu.mx>.

\begin{tabular}{l|l|l|l|l|l|} 
R. Educ. Públ. & Cuiabá & v. 28 & n. 67 & p. 151-168 & jan./abr. 2019 \\
\hline
\end{tabular}


Nadie como la maestra y escritora chilena Gabriela Mistral (1897-1957), encontró en el género capitular, desde muy pequeña, un bálsamo para la timidez y para la soledad. Como a tantas mujeres educadas de principios del siglo XX, las cartas le permitieron no solo expresar, sino construir sus pensamientos y sus sentimientos, construirse una identidad. Las cartas por ello son parte de la construcción reflexiva de la realidad emocional de las mujeres. ${ }^{2}$ Para una escritora como ella, la escritura lo era todo, las cartas le permitían poner en muchas partes del mundo sus pensamientos y sus emociones, quizá más difícilmente expresadas en forma oral y cara a cara.

Vivió un intenso amor por cartas con Fernando Magallanes, por más de siete años. Las cartas eran olidas y guardadas, le hacían sentir el fuego con solo tocarlas en el bolsillo, decía.

Vivía para escribir y leer cartas, estando en la Patagonia en su periplo de maestra escritora y luego por todo el mundo, como una verdadera patiloca, siempre estuvo bien conectada con los suyos, a través de las cartas.

Especialmente con sus amigas, acompañantes (Laura Roding, Palma Guillén, Consuelo y Doris Dana), mal llamadas secretarias, compartía vínculos poderosos y hasta "sentimientos extraños", plasmados a través de cartas, que leía hasta tres veces o más, eran un bálsamo para la ausencia, eran las que le permitían incluso sobrellevar los últimos años de su vejez y enfermedad, en New York.

\section{Gabriela y lo epistolar}

Las cartas como una práctica específica de escritura constituyen una historia de la sociabilidad a través de las mediaciones de la escritura. Autoras como Patrizia Violi afirman que es una práctica que pone de manifiesto la ausencia, del interlocutor, es una especie de diálogo diferido que destaca por construir al ausente mediante reconstrucciones imaginarias, dado que la escritura sucede en un tiempo y en un lugar distintos. Finalmente existe una tensión entre la realidad y la verdad histórica del sujeto o actor social auténtico, y la representación discursiva, una realidad pasada por las mediaciones del actor que escribe. Son dice Violi "verdaderos simulacros de una realidad pasada por el filtro del individuo". (Violi, 1987; 89).

2 Castillo, Darcie Doll. (2000). El discurso amoroso en las cartas de Gabriela Mistral. Revista signos, 33(47), 11-23. <https://dx.doi.org/10.4067/S0718-09342000000100002> 
En este sentido Gabriela Mistral, como autora de cartas, se convirtió desde muy joven en una gran experta del género capitular. Tuvo una reflexividad e introspección constante a partir de cartas privadas. Escribía mucho a sus más cercanos amigos, a sus seres queridos y a otras muchas personas de otras partes del mundo. No solo fue un medio para socializar, sino que sus cartas tienen elaboraciones escriturales muy suyas, pues modela y construye la presencia del interlocutor ausente, con gran maestría. En sus cartas hay un trabajo de creativa intimidad con las ausencias, hay narrativas intensas con variados detalles que ofrecen etnografías del viaje, etnografías del deseo y etnografías emocionales muy variadas. Hay textos y contextos, que retan a la interpretación rigurosa, así como la enunciación de pactos de escritura e intersubjetividades implícitas muy complejas.

En este trabajo haremos una aproximación al tejido epistolar sostenido entre la escritora con su amiga mexicana, Palma Guillén. Una relación que inició en 1922 y duró hasta la muerte de Gabriela Mistral en 1957, continuando posteriormente con Doris Dana. Será esta temporalidad el contexto temporal de nuestro análisis, aunque en forma específica se revisarán las cartas que Palma escribió a Gabriela entre 1942 y 1957, por ser estas públicas (Zegers, 2011).

\section{Palma y Gabriela}

Pese a ser muy conocida la relación entre Palma y Gabriela, de la primera se sabe muy poco. ${ }^{3}$ De tal modo, que aparece a la sombra de Gabriela, enunciada como la secretaria asignada a la escritora, la Palmilla en la correspondencia mistraliana. Se trata de una imagen que choca con la historia deseable por las feministas mexicanas, es decir la Palma de Gabriela es servicial, maternal, una hermana mayor que está dispuesta a dedicar su vida y su tiempo al cuidado y confort de los otros. Palma cuidó de Gabriela desde el momento mismo en que la conoció y aún más allá de su muerte. Ordenaba por igual su correspondencia, que editaba textos o hacía gestiones consulares y notariales, cocinando o cuidando de la crianza del hijo adoptivo de Gabriela y aún después de fallecida la escritora, se seguía ocupando de poner en orden asuntos de sus propiedades y el cuidado de su honor, o atendiendo pendientes editoriales. Gabriela también se preocupaba por Palma, usando un tono de proveedora, aparece como solidaria en gastos y herencias. Esa relación aparece en el tejido epistolar.

3 La Dra. Gabriela Cano, una de las biógrafas de Palma Guillén, señala que reconstruir su biografía es una empresa muy difícil. 
Palma Guillén, (1898-1975) era profesora de materias de lógica, literatura, psicología y Gabriela profesora en Liceos de niñas daba cursos de Lengua Castellana y de Geografía. Palma a casi diez años de la muerte de Gabriela, analizó nuevamente su encuentro con Gabriela, en 1966, cuando reescribió la presentación a las Lecturas para mujeres de GM., ahí reconoce que se vio entonces como una chica presumida frente a Gabriela, era imponente la poeta, por ello: "Confieso que la misión no fue muy fácil. Gabriela era una persona de formación muy diversa de la mía. Sabía mucho y de muchas cosas y todo lo había aprendido por sí misma, sin escuela ni maestros". ${ }^{4}$

Palma también se interesó en la diplomacia y fue una de las primeras mujeres mexicanas en representar a México en labores consulares. Perteneció al grupo de intelectuales de la Universidad Nacional, que colaboraban en la gran obra de Vasconcelos cuando este fue nombrado ministro de educación por el Presidente Álvaro Obregón.

El Vasconcelos de ese momento era gigante en las memorias de Palma:

José Vasconcelos había echado a andar la gran máquina de la Secretaría de Educación -poca herramienta, en aquellos años, y mucho espíritu- y todos los jóvenes de entonces íbamos con él llenos de entusiasmo. Éramos su equipo de trabajo, las manos con las que él abría, alegremente, sendas nuevas en el ambiente de México. ${ }^{5}$

Palma relataba que Vasconcelos la eligió para acompañar a Gabriela, para mostrarle el mundo educativo rural y presentarla en México. Era la anfitriona par de Gabriela, no la "secretaria" asignada. ${ }^{6}$ Palma relata las motivaciones del Ministro al elegirla para tal tarea:

[...] cuando Vasconcelos supo que Gabriela había aceptado la invitación que nuestro Gobierno le hizo a través de nuestra Legación en Chile, me llamó y me dijo: -"Palmita, va a llegar Gabriela Mistral. Viene a trabajar con nosotros. Yo quiero que conozca bien a México. Quiero que vea lo

4 Palma Guillen, presentación en Gabriela Mistral, Lecturas para mujeres, SEP, México 2a reimpresión, 1988.

5 Ibid.

6 Palma afirma: "Mucha gente dice que yo fui secretaria de Gabriela. No, su secretaria fue Eloísa Jaso, que aún vive, la hermana de la gran maestra Carlota Jaso.” presentación en Gabriela Mistral, Lecturas para mujeres, SEP, México 2a reimpresión, 1988. 
bueno y lo malo que tenemos aquí, lo que estamos haciendo y lo que nos falta... ¿ ¿Usted sabe quién es Gabriela Mistral?” (Yo sabía muy poco - puedo decir honradamente que no sabía nada de Gabriela Mistral ... Había leído en alguna revista los Sonetos de la Muerte; pero no estaba enterada de las ideas pedagógicas, sociales y otras de Gabriela, ni sabía lo que ella significaba, ya desde entonces, en el Continente... ) -"Ella tiene muy buenas ideas sobre la educación. Es una mujer de la provincia, casi del campo, y sabe lo que necesita la gente del campo. Es una gran maestra y una gran poetisa. He pensado mucho a quién puedo confiársela aquí para que la acompańe y la guíe. No quiero que tenga una visión equivocada o parcial de México. No quiero que la hagan ver sólo lo bueno o sólo lo que le interese a la persona que la guíe. Yo quiero que Gabriela lo vea todo, que nos dé su opinión acerca de todo lo que estamos haciendo y que nos ayude con su experiencia y con su intuición. Es una mujer genial, admirable. Pienso que Ud., que es menos doctrinaria que Fulana y menos especializada que Zutana, podría ser más útil para esta misión. Ud. viajará con ella, le hará conocer el país: lo bello y lo feo, lo bueno y lo malo, la capital y la provincia -el campo sobre, todo-, la Universidad y la escuela rural, etc. ${ }^{7}$

Era para Gabriela el primer viaje largo al extranjero, era un viaje apoyado por las instituciones de gobierno e iba acompañada de dos colaboradoras chilenas, Palma recuerda que la famosa poeta no era lo que ella imaginaba, fue cuando ella aprendió a leer los ojos de Gabriela:

Gabriela Mistral llegó en un barco que la trajo de su lejana tierra. Fuimos a recibirla al puerto, en nombre de la Secretaría, Jaime Torres Bodet y yo. No sé la impresión que Gabriela hizo a Jaime Torres Bodet. A mí, que era una muchacha presumida, me pareció mal vestida, mal fajada, con sus faldas demasiado largas, sus zapatos bajos y sus cabellos recogidos en un nudo bajo. Veo los ojos temerosos de Gabriela. Aquellos ojos, casi siempre cubiertos por los párpados caídos, tenían dos modos de mirada: una mirada rápida y relampagueante en la que podía estar el

7 Ibid. 
encantamiento, la sorpresa, la cólera o el temor -muy frecuentemente el temor- y una mirada serena, sostenida, que era como un agua encantada, como una agua verde con mucha luz adentro: la mirada de la confianza, de la comprensión, del reposo; pero, la mayor parte del tiempo, sus ojos eran como pájaros asustados. ${ }^{8}$

Qué tenían en común estas mujeres además de ser interlocutoras y admiradoras de José Vasconcelos? Al respecto dirá Palma, que tenían más bien diferencias. Palma era de naturaleza urbana y se autodenominaba como una seńorita presumida, bien vestida y moderna. Mientras que Gabriela, era de naturaleza rural, era una campesina ilustrada, proveniente de un pueblito minúsculo perdido en el norte de Chile, del cual no se tenía mayor referencia. Gabriela no mostraba interés en destacar su femineidad, era más bien como una monja pobre. Tenían el carácter muy diferente y de diferentes geografías y oscuridades, Palma siempre fue tolerante y gentil:

De carácter, sobre todo, éramos muy diversas: ella, mujer de la montańa, yo, mujer del altiplano. En Gabriela había muchas zonas oscuras, honduras y misterios -aquello que sabía de "ceniza y firmamento", / "..mi flanco lleno de hablas y mi flanco de silencio, y lo que supe, temblando, de manantiales secretos...",/ oscuras cosas que yo no comprendí al principio o que no comprendí nunca; pero que supe respetar siempre. La cortesía que, dígase lo que se diga, es una virtud, puesto que consiste en darse cuenta de que los demás existen y en respetarlos, me sirvió grandemente en el primer tiempo.

Así, juntas recorrieron muchos lugares de la amplia geografía mexicana, hubo sitios a los que volvían, se hicieron unas grandes viajeras y compañeras de viaje, la misma alma disfrutó y aprendió día a día de ese primer periplo mexicano:

Me veo en el tren, con ella, de un lado para otro: Pachuca, El Chico, Cuautla, Cuernavaca, Puebla, Zacapoaxtla, Atlixco, Taxco, Pátzcuaro, Zamora, el Cañón de Tomellín, Oaxaca, Acapulco, Guadalajara, Querétaro, Veracruz. . .

8 Ibidem.

9 Ibidem. 
Sol, polvo, calor. Escuelas instaladas en viejos curatos, en patios, en solares, en casas particulares, casi sin muebles. Llegábamos en tren o en los camiones de la Secretaría -a veces dormíamos en ellos ... ${ }^{10}$

Tenían conversaciones interminables en las que también participaba la madre de Palma, y hasta se llegó a quedar a dormir en su casa. Intimaron, se familiarizaron, se quisieron como hermanas. Palma señala que su contacto con Gabriela la enriqueció, le volvió los ojos a la América Latina en tiempos en que casi todos los intelectuales mexicanos miraban a Europa y a Estados Unidos:

Ella estaba centrada en la América y aunque se hubiera leído, traducidos al español, a muchos escritores clásicos y modernos, era la América, la América Latina, la que le importaba. Yo estaba más cerca de Europa y, sobre todo de Francia, que, de Colombia o la Argentina y sabía más de Homero, de Lucrecio, de Schopenhauer o de Bergson que de Miranda, Sarmiento o Rodó, aunque hubiera hecho mis cursos de literatura hispanoamericana con el gran maestro Pedro Henríquez Ureña y aunque me supiera de memoria muchos versos de Darío y de José Asunción Silva. Además, ella era un gran poeta y los grandes poetas se mueven en una atmósfera que a veces ahoga a los simples mortales. ${ }^{11}$

Gabriela cargó en el barco con todos sus libros porque iba lista para hacer una antología de lecturas para mujeres. Encargo que cumpliera en medio de críticas y desavenencias con la intelectualidad literaria y normalista, eran momentos de intenso nacionalismo y ella fue tratada como extranjera. Le cuestionaban a Vasconcelos el honor de hacer una escuela que llevara su nombre y que le encargarán hacer una antología de lecturas y peor aún, que hicieran una estatua de la maestra. Palma recuerda:

Hubo, personas que empezaron a hacer críticas y comentarios malévolos. -”...¿Qué venía a enseñar, que no supiéramos ya, esa 'extranjera'? ¿Qué novedades había traído? Aquí había muchos buenos maestros y cualquiera de ellos podría hacer en la provincia lo que hacía Gabriela... ${ }^{12}$

10 Ibidem.

11 Ibidem.

12 Ibidem. 
Adolorida Gabriela terminó su visita para ir a los Estados Unidos, Palma afirma que trataba de ocultarle las malas noticias, pero se enteró y ella que tanto amaba a México, se sintió tratada como una extranjera. Gabriela amaba a México desde antes de conocerlo y durante su estancia, lo amó más. Se reunía con campesinos, con maestros con cuantos pudiera. La escuchaban con un fervor casi religioso. Gabriela tenía el don de la palabra y un gran conocimiento de la vida rural, ayudaba con recomendaciones pedagógica y abonaba los corazones con su poesía, su prosa y su etnografía permanente.

Las actitudes xenófobas acabaron por bajarle los ánimos y Palma fue testiga del dolor que le causaban esos comentarios:

Yo sé bien lo que le dolió sentirse "la extranjeras", llamarse a sí misma "la extranjera" en este país que amó tanto como al suyo y del que quería ante todo ser amada. La Introducción escrita por ella es una admirable presentación y exposición del libro en la que Gabriela desarrolla, sus ideas acerca de la educación en general y acerca de la educación de la mujer en particular; pero es también una respuesta llena de dignidad, a las críticas y a las ofensas que le hicieron, En ella casi se excusa de haber venido a trabajar entre nosotros y para nosotros -ella que, dentro de su hispanoamericanismo verdadero y total, soñó siempre con una América Latina sin fronteras en la que el pensamiento y el trabajo pudieran circular libremente para bien y alegría de todos. Firma con las palabras $L a$ Recopiladora, sin poner su nombre, para disminuirse como la disminuían y para quitarle importancia a la obra en la que la décima parte, cuando menos, del material tan novedoso como bien escogido está formado por textos suyos, escritos muchos especialmente para este libro. ¡Pobre Gabriela, tan maltratada, tan injustamente atacada y tan sola siempre!. ${ }^{13}$

Palma entabló una relación profunda con Gabriela Mistral, nunca más dejaron de estar en contacto, incluso se llegaron a llamar mutuamente carińosamente "hijitas". Se escribieron cartas a lo largo de toda su vida. Incluso su primera obra publicada de poesía, Tala, fue dedicada a Palma.

Con Gabriela estuvo en diferentes momentos de grandeza y de profunda tristeza. Uno de los lazos íntimos más significativos, fue sin lugar a dudas, compartir legal y cotidianamente la crianza y responsabilidad formal de Luis Miguel Godoy, hijo adoptivo a quien llamaban Yin Yin.

13 Palma Guillen, 1966. 
Palma sería su brújula en el mundo de los viajes y de las relaciones consulares, sería la que fue educada para socializar y la que además siendo bien avezada en francés, era también buena editora de sus textos y una fiel muy fiel acompañante en los periplos mistralianos por el mundo europeo y de la diplomacia.

Había entre ellas una hermandad sororal ${ }^{14}$ llena de ternura e incondicionalidad, eran amigas intimas, madres-cómplices de la educación de Yin Yin, camaradas pacifistas, activistas antifranquistas y a ratos socias. Palma la infaltable para soportar el mal carácter y las oscuridades de la poeta, las constantes depresiones y amarguras de la controvertida Gabriela.

No entraremos aquí a discutir la vida sexual en el subconsciente de nuestros personajes, pues se ha hecho mucho ruido a partir de las cartas, afirmando que Gabriela era una lesbiana tardía y que fue la Queer mother de América. ${ }^{15}$ Aunque la soledad de Gabriela es muy transparente, no es fácil llegar a comprender su sexualidad, pero es cierto que en sus cartas y poemas, existe el discurso amoroso fragmentado, se entrevé y se lee un erotismo contenido y latente a de su interlocución con hombres y mujeres. A unos y a otros les dedica bellas palabras y poemas para explicar sentimientos telúricos, carnales, donde lo corporal, lo sensual y lo espiritual se configura con palabras. Hay mucha poesía en su escritura.

No olvidemos que la historia de las mujeres del siglo XIX era muy segregada, las mujeres tenían que aliarse para poder hacer vida social, productiva, pública o intelectual. Incluso formaban sociedades femeninas mutualistas de mujeres para proveerse cuidados en la vejez. Estas sociedades no necesariamente eran homosexuales, muestran eso si la ausencia de un estado de derecho para las mujeres. Eran comunidades sororales para enfrentar el desamparo. Una gran cantidad de casos de mujeres intelectuales y viajeras, no tenían pareja y establecían alianzas sororales duraderas y fuertes con sus similares. El afecto incondicional entre amigas, escrito en los términos y convenciones del lenguaje de género del siglo XIX, es lo que quedó documentado en la biografía epistolar de la relación entre Palma y Gabriela. ${ }^{16}$

14 Sororal enuncia en primer término la posibilidad de las mujeres de ser hermanas, en términos de fraternidad, el feminismo estadounidense acuńó el término como sisterhood. Actualmente el feminismo reivindica las dimensiones éticas y políticas de la unión y ayuda entre mujeres para enfrentar la desigualdad y la discriminación.

15 Fiol-Matta, Lucía A Queer Mother for the Nation: The State and Gabriela Mistral. Minneapolis, Minn., University of Minnesota, 2002.

16 Recuérdese que los usos históricos del lenguaje amoroso se transformas. Por ejemplo el término "hacer el amor" en el siglo XIX era usado para referirse al cortejo y actualmente se usa para señalar una relación sexual. 


\section{Un epistolario sororal}

Se decían "hijitas", Palma era su "hijita querida”, y Palma se decía "tu Palma” para despedirse. En los usos coloquiales y populares en México, es común usar esos términos para expresar afecto y cuidado, entre familiares y mujeres. En el sureste mexicano, por ejemplo, las mujeres pueden decirse "mamita", "hijita", "manita", "linda", "bonita", "chiquita", "preciosa”, para suavizar más una conversación. Encuentro un uso muy mexicano, popular y sororal en el uso que Gabriela y Palma dan a esas maneras de escribirse y nombrarse.

Por lo demás, el contenido de las cartas confirma una poderosa amistad entre mujeres que dan peso a lo íntimo como importante.

Acompañaban las cartas con recortes de periódico sobre las vicisitudes de la guerra y con mil detalles sobre los cuidados de la salud, medicinas y noticias de las andanzas de las otras "amigas". Eventualmente con algún cheque-casi siempre Gabriela- para ayudar en los gastos, Nada de vanidad se percibe en su relación que pudiera denotar egos de divas o de mujeres con influencia en la literatura y la diplomacia. Aunque ciertamente cada una tenía sus espacios de poder público. Eso, lo público, es lo que aparecerá en los diarios o en las gacetas. En sus cartas se abordaba lo importante, la salud, los sueños, las añoranzas, sin el lustre del paso de la premio nobel por los diferentes foros del mundo. Incluso Gabriela se refiere al PN.

En las cartas se teje lo profundo de sentimientos y lealtades, los recuerdos buenos y hermosos de los viajes. Se habla también del oficio importante de la escritora, de las pérdidas de habilidades y capacidades, Gabriela que pierde papeles y libros y cheques y cartas entre tantas valijas. Además no deja de emprender grandes proyectos literarios o editoriales, para los que no tiene más que aceptar invitaciones a través de cartas.

En las cartas privadas se aborda lo privado, lo que duele lo que se añora y lo que no se dice en público. Gabriela es como la hermana mayor, aunque no la más fuerte, se conocen: Palma es una gran gestionadora de los asuntos de Gabriela, incluso estando en México sigue atendiendo por las vías diplomáticas, múltiples asuntos de la premio nobel. Fuera atendiendo asuntos de propiedades inmobiliarias o de propiedad intelectual.

Gracias a la publicación de las cartas que intercambiaron de 1942 a 1957 publicadas por Zegers, $(2001,2007,2009,2014)$ podemos conocer las cartas para recrear al detalle esta histórica amistad sororal. 


\section{Las cartas en el infortunio}

La mayor lealtad de Palma con Gabriela fue la de compartir la crianza de Yin Yin, sobrino de Gabriela y que Palma firmó en Tuición ante notario, para compartir los cuidados. Así lo hizo y en múltiples momentos aparece con YY en vacaciones y la vida doméstica.

Para ambas amigas era importante escribirse para contarse los sueños, especialmente le dice que ella que sueña poco, cuando sueña a Gabriela entra en una gran angustia por compartirlo todo:

\section{La Habana, agosto 17/942.}

Hijita querida:

He estado con mucha preocupación por ti estos últimos días porque te he soñado. Ya sabes: yo sueño raramente y cuando la gente me visita dormida por algo es. -Anoche mismo volvía a tenerte conmigo en el sueño: no se bien que era. Tú te ibas con otra persona dejándome a un lado sin hacerme caso; pero estabas contenta-: te oía -te oigo aún- reir alto- Antes de ayer fue otra cosa. Me sońé muerta, hijita. Estaba en tu casa contigo y con Yin Yin [hijo adoptivo de Gabriela] pero estaba muerta, y vosotros no me veíais- Hoy, al desayunarme, le dije a Luz [hermana de Palma] -Tengo miedo de que le pase algo a Gabriela -porque la he soñado tres noches seguidas [...]. Tengo muchas, muchas ganas de verte Chinita querida y de ver a ese sinvergüenza de Yin Yin. Cuida mucho tu salud, hijita, y procura no estar triste.. [...] (Firma: Te besa y te bendice... tu Palma) (ZEGERS, 2011,17).

$\mathrm{Al}$ año siguiente justo en agosto 14, Yin Yin el hijo adoptivo que Gabriela y Palma adoraban, se quitó la vida dejando en ellas una gran tristeza. Durante 1942 y 1943 , las cartas expresaban esa preocupación por atender y orientar al adolescente difícil. Gabriela entonces radicaba en Petrópolis, Brasil, ante la rebeldía del muchacho, había optado por meterlo a una escuela agrícola, para que se fortaleciera y se ocupara la mente en cosas prácticas. El chico expresaba que no le gustaba estar ahí, y para desconcierto de su madre, nada completaba y nada le gustaba, incluso llegó a consumir alcohol, lo cual en el marco disciplinario de la época era inaceptable.

Así, comparten las reflexiones y medidas para mejorar la crianza de Yin Yin al que a veces llama Juanito ${ }^{17}$, quien se encontraba indeciso de su orientación vocacional a los 18 años:

17 Juan Miguel Godoy Mendoza (1925-1943). 
La Habana, sept. 23/ 942.

Hijita linda y querida:

Acabo de recibir una carta de Juanito que me ha dejado una impresión muy penosa. Me habla en ella de su deseo de ser aviador y me ruega que no me oponga. Le he contestado lo que te contesté a ti a ese respecto: que no estaría mal que se hiciera hombre - que es lo primero que tiene que ser un aviador: hombre fuerte, disciplinado, firme y tranquilodedicándose a la aviación. [...] Que si tu lo has puesto en la escuela agrícola es porque quieres comprarle una finquita - no para que el trabaje directamente la tierra, sino para que la explote y la dirija. [...] Necesitas tener con él a la vez firmeza y ternura hijita, porque de ambas cosas necesita mucho - su carta está llena de rencorrencor contra ti, aunque no lo dice - contra los aduladores que te rodean (así dice) [...] La crisis de la adolescencia es siempre cosa muy seria, hijita, sobre todo cuando se tiene un temperamento nervioso y débil como es el caso de Juanito. [...] Me aflige no poder irme contigo enseguida contigo para ayudarte en este grave momento- [...] Te abrazo, mi pobrecita. Ten calma; firmeza y paciencia es lo que más necesitas en estos días - Te abrazo. Cada noche rezo por ti y por YY. Mil cariños y bendiciones de tu ... Palma. (ZEGERS, 2011,22)

Gabriela en sus cartas expresa también la demanda de apoyo de Palma para sacar adelante su trabajo cuando la abandona su secretaria Conie y no puede con el hijo,- confía en que a ella la escuche-, pues el chico incluso la asusta por su enojo y su rebeldía. Palma desde México y cuidando a su hermana Luz de un problema cardiaco, trata mediante cartas, apaciguar la situación en lo que logra por fin irse a Petrópolis.

Agosto 2/ 943.

Mi querido Juanito:

[...] Hijito querido, tu puedes ser la ayuda, el consuelo, la alegría y el descanso de tu mamita- selo. [...] Pronto llego yo, hijito, entretanto cuida a tu mamita como si fueras yo misma. ¡Por lo que más quieras! Dios te mira, Juanito mío querido - acuérdate y tenlo presente. Te besa y piensa siempre en ti tu ... Palmita. (ZEGERS, 2011, 43). 
El domingo 15 Palma envía una carta que expresa su total angustia por la crisis que pasa Gabriela:

Hijita estoy como si me hubieran dado un golpe en la cabeza: acabo de recibir tu cable puesto ayer 14 a la 14.13 en el que me dices tan solo: "Vente inmediatamente" -Qué pasa, qué pasa Dios Mío? - Si, Hijita, si, me iré en seguida _ es decir enseguida que pueda... mañana hipotecaremos la casa para tener dinero. Y mańana temprano iré a ver a Tello para que me pidan la prioridad en el avión por conducto de la Secretaría -Que la maleta grande se vaya por barco o que no se vaya _ Lo único que quiero ahora es saber qué pasa y estar contigo - ay si pudiera dormirme y amanecer alláii pero todo esto es imposible -Hay que hacer no se cuantas cosas y que hacerse pedazos de angustia en la oscuridad_Que pasa por Dios? Por qué no me dices siquiera una palabra para alumbrarme de algún modo? Voy a seguir con las maletas para dejar siquiera una terminada. Mi pobrecita qué te pasa? Estás enferma? Se porta mal Juanito?

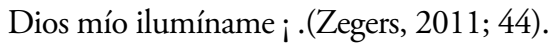

En esos momentos dolorosos Gabriela buscaba entender por qué Yin Yin se había quitado la vida. Ella desde meses atrás le había escrito a Palma que pensaba que andaban presionándolo otros chicos, para pedirle dinero y que todo esto era confuso. Pues el hijo estaba insoportable y deprimido. Ambas sabían de este carácter nervioso y difícil, pero además Gabriela percibía un ambiente fascista en la escuela que afectaba a los jóvenes.

Asimismo para Palma lograr todos los visados para llegar a Brasil era un ir y venir a oficinas para lograr 7 visas.

Martes 17 -19 horas

En este momento llega tu cable. Es verdad eso, Dios mío? Es juanito el enfermo? - Tengo ya cuatro visados, hijita mía, mi pobrecita? Mañana en la mañana tendré los otros tres, y... el dinero. Las maletas están casi terminadas y los papeles también -La prioridad me será dada también mañana. Hay aviones diariamente hijita, supongo que tomaré la vía pacífico porque, aunque más larga, es más rápida porque las prioridades se tienen con más facilidad -La maleta grande se irá en septiembre o cuando se pueda. Voy a seguir con los papeles para que mis cosas se queden en el mayor orden posible -Rezo por ti y por mi Yin Yin a toda hora. TU HIJITA PALMA. (Zegers, 2011; 43). 
Gabriela estuvo sumida en un profundo dolor por la pérdida de su Yin Yin, Palma la cuidó la reconfortó la cuidó, juntas rezaron y lloraron. Gabriela era nuevamente tocada por el infortunio y la muerte le arrebataba a otro ser querido. Palma se autonombra su hijita, la alienta a retomar la pluma a no perder la razón por tanto sufrimiento.

\section{Compartiendo la gloria}

Casi a finales de 1945, Gabriela Mistral es notificada de que le otorgarán el premio Nobel de Literatura. Un honor descomunal para la época por darlo a una mujer escritora, de América Latina. Palma le escribe emocionada:

\section{México, nov. 16/945.}

Mi Hijita querida:

Hoy en la mañana, temprano, me habla por teléfono Alfonso Reyes para darme la noticia de que te dieron- ipor fin!, el Premio Nobel - que te pusiera un cable de los dos diciéndote su gran alegría por la noticia. Estaba feliz y me dijo cosas preciosas de ti y de esa prosa tuya ue él adora y que es "como una brisa". Hijita querida, [...] hay como me duele no estar contigo, no haber sido yo quien te lleve los diarios con el cable a tu cama en la mañana; Dónde estás? En Petropolis? En Río? - [...] Hijita, ¿Qué es lo que hay que hacer con motivo del premio? Creo haberte oído decir que había que ir a Estocolmo [...] te abraza cien veces tu hijita que no te olvida un momento. PALMA. (Zegers, 2011;47).

Palma en México empezó a ser buscada para pedirle mediara con Gabriela Mistral, para homenajes y ediciones de libros. Ella recortaba las notas de los periódicos que hablaban del premio y los enviaba a Gabriela acompañando las cartas. También daba gracias a Dios "por este bien que te ha hecho" aunque tarde. No obstante a la par de hablar del Premio Nobel, (Gabriela lo nombró el PN) sin adulaciones, más era lo que hablaban de otras cosas domésticas y cotidianas, sobre la política en Brasil y en México. Palma representa a Gabriela en reuniones donde se lee su poesía, Junto a Carlos Pellicer, cuya amistad permanecía, ellos en Bellas artes, que la recibieron en el muelle, dos décadas atrás, mantenían la amistad y la lealtad a Gabriela, ahora si apabullada de aduladores. 


\section{Juntas en la enfermedad}

Los siguientes 12 años posteriores al premio nobel fueron confortable y difíciles para Gabriela, que a la par de ser muy influyente y muy solicitada, también resultó enfermar del hígado, la diabetes y el corazón. Contrayendo finalmente un cáncer de páncreas que le costó la vida en 1957. Los médicos más famosos del mundo la veían y el Dr. Chávez, destacado Cardiólogo, afirmaba que Gabriela tenía más bien soledad en su vida en los Ángeles.

Palma en estos años, realizaba labor consular intensa y tenía un trajín diplomático del que no hablaba mucho en las cartas, pero tiene muchos viajes, recepciones con embajadores y delegaciones diplomáticas. Es decir tiene puestos importantes. A la par también cuidaba de su esposo enfermo y de ella misma, con días buenos y otros no tanto. Gabriela que no paraba de recibir homenajes y dictar conferencias, siguió viajando mucho por un tiempo, además encontró nuevas aliadas y se trasladó a Nueva York, sólo en los últimos años ya no podía viajar tanto como antes, incluso aún no recuperaba sus libros de maletas y mudanzas anteriores. Pedía a Palma que le enviara libros en Español, que eran más fáciles de conseguir en México que en Estados Unidos. Consultaba médicos y compartía con Palma los detalles de medicamentos y de remedios. Compartes datos de su peso, sus niveles de azúcar y las vitaminas que están tomando. Palma por su parte le hacía llegar muchos libros, cartas en Español para que no lo olvidara y las buenas hierbas y remedios mexicanos, acompañados de cartas con muchos consejos de dietas y de ejercicios para la diabetes de Gabriela. La ayudaba a llevar las cuentas y a gestionar la renta de sus casas en Brasil y en Santa Bárbara.

Le recordaba la situación de cada amigo, le recomendaba a otros libros y escritores que esperan su aprobación y unas líneas para ayudarlos. Le recortaba información útil para su Poema de Chile, la gran obra de Gabriela.

\section{Las cartas poéticas de Gabriela}

Aún en los momentos de mayor trabajo y enfermedad y agotamiento. Gabriela y Palma tienen, momentos de intercambios de las cosas bellas, de añoranzas bien colocadas. En los últimos años de su vida Gabriela vivió en los Ángeles y luego en Long Island con Doris Dana, no dejaba por ello de escribirle a Palma, regalando algún trozo poético o de buena prosa. A veces daban por implícito el lugar y la fecha. Tiempo y espacio era para ellas parte de ese transitar por la amistad, pero ellas vivían la amistad a través de las cartas, así cuando Palma le recomienda pasear y acercarse al mar por sus efectos saludables, Gabriela le responde: 
1953

Querida mía:

Gracias por tu cartita, leída con doble gusto por nombrarme... al Mar mi marido! No sabía nada de eso del mar y ahora me da pena porque - no se si te lo dije - No me atrevo con Él. Yo te conté esto. Me puse a jugar con él y a decirle cosas y a la vez a echarle en cara, la gente que él ha ahogado! Y se me vino encima, Palma. Es cierto - tú has visto el pedazote que yo tengo de pagana. Lo tengo sin vuelta. Yo creo que todo ser con infancia en el campo no lo mira como - esa agua loca no mas, lo mira sin darse cuenta como "otra cosa", uno de los diocesitas de los antiguos. Yin me lo vio - todo veía él- y me lo dijo, y yo tuve que darle la razón, porque es verdad. [...] GAB. (Zegers, 2011; 306).

\section{A manera de conclusión, las cartas de pésame del pueblo}

En una carta de 1951 Palma expresó una frase significativa del alto poder de la intensa relación epistolar que tenía con Gabriela. "Y te escribo constantemente lo mismo cuando te tengo cartas tuyas que cuando no las tengo". Así es como las cartas trazan el repaso mental de amistad entre dos mujeres que compartieron la mejor y lo peor de la vida. Una amistad a ritmo epistolar, que se comunica y se piensa en formato epistolar.

Incluso al final fueron las cartas las que le revivían el amor a la poeta, dice Palma: "Cuando murió, de muchos de esos pueblos, recibí yo cartas de pésame de personas que, 35 años antes, la habían conocido y que me escribieron a mí porque no sabían si ella tenía aún familia”.

\section{Referencias}

ALEGRÍA, CIRO. 1989. Gabriela Mistral intima. Santiago de Chile: Antártica. BARROS VAN BUREN, MARIO. 1990. Historia diplomática de Chile 15411938 (actualizada a 1958). Santiago: Andrés Bello.

BARRY WILKINS DOUGLAS, 2015. Gabriela con valija diplomática. La génesis de la vida consular de Gabriela Mistral, CONTEXTOS, No 33, 113-123

FIOL-MATTA, LUCÍA, 2002. A Queer Mother for the Nation: The State and Gabriela Mistral, Minneapolis, Minn., University of Minnesota. 
GUILLÉN, PALMA 1988. "Gabriela Mistral (1922-1924)”, en Mistral, Lecturas para mujeres, México, Secretaría de Educación Pública.

GÓNGORA, MARÍA EUGENIA. (2004). Construcción del sujeto femenino en el diario y la carta de amor: Lily Ińiguez y Gabriela Mistral. Revista chilena de literatura, (64), 149-154. https://dx.doi.org/10.4067/S071822952004000100011

HORAN, ELIZABETH. 2009. "Una mixtura de calvario y arcadia: La Cónsul Gabriela Mistral en Portugal,1935-1937”. Anales de la Literatura Chilena Vol. 11: 13-43.

MORAGA VALLE FABIO, 2014, "Lo mejor de chile está ahora en México", ideas políticas y labor Pedagógica de Gabriela Mistral en México (1922-1924), El Colegio de México, Historia Mexicana, XIII: 3.

MUNIZAGA IRIBARREN, MIGUEL. 1935. "Vida y confesiones de Gabriela Mistral”. Familia Vol. 19: 28-29 y 75-76.

QUEZADA, JAIME, 1995. Gabriela Mistral, escritos políticos, Santiago, Fondo de Cultura Económica.

ROJO, GRÍNOR, 1997. Dirán que está en la gloria. Mistral, Santiago, Fondo de Cultura Económica.

SCARPA, ROQUE ESTEBAN.1977. Una mujer nada de tonta. Santiago: Andrés Bello.

TAGLE DOMÍNGUEZ, MATÍAS. 2002. Gabriela Mistral y Pedro Aguirre Cerda a través de su correspondencia privada (1919-1941), HISTORIA, Vol. 35: 323-408.

TEITELBOIM, VOLODIA. 1991. Gabriel Mistral, Pública y Secreta. México, Hermes.

MISTRAL, GABRIELA, Lecturas para mujeres, SEP, México 2. reimpresión, 1988. $496 \mathrm{p}$.

VIOLI, PATRIZIA. La intimidad de la ausencia: formas de la estructura epistolar. Revista de Occidente, 68 (1987): 90.

VIOLI, PATRIZIA. El infinito singular. Madrid: Cátedra, 1991.

VIOLI, PATRIZIA. La intimidad de la ausencia: formas de la estructura epistolar. Revista de Occidente 68 (1987): 87-99. 
ZEGERS, PEDRO PABLO, 2001. Recopilación de la obra mistraliana, 19021922, Santiago, RIL-Editores.

ZEGERS, PEDRO PABLO (Comp.). 2007. Gabriela Mistral y México, Santiago, RIL-Editores.

ZEGERS, P. (ed.) (2009). Gabriela Mistral, niña errante: cartas a Doris Dana. Santiago: Editorial Lumen. 


\title{
Reformas na educação profissional brasileira na década de 1990: consenso e hegemonia
}

\author{
The purpose of reforms in brazilian professional education in \\ the 1990s: \\ consensus and hegemony
}

\author{
Arão Davi OLIVEIRA ${ }^{1}$ \\ Celeida Maria Costa de SOUZA e SILVA²
}

\begin{abstract}
Resumo
Objetiva-se apresentar e discutir as propostas e interesses do empresariado nacional e dos organismos internacionais na reforma da educação profissional brasileira na década de 1990 . Essa é uma pesquisa qualitativa de abordagem documental e bibliográfica. Foram analisados documentos emanados por essas instituiçóes na década de 1990 à luz dos conceitos de estado, de Gramsci (1991), acumulação flexivel do capital, de Harvey (1992), e trabalho, de Marx (1971). Os documentos analisados promoveram um consenso no âmbito educativo nacional e serviram de referência para a proposição de reformas no sistema educacional brasileiro, que passou a priorizar uma formaçáo geral, flexível e polivalente.
\end{abstract}

Palavras-chave: História da educação profissional. Políticas Públicas Educacionais. Acumulação Flexível do Capital.
Abstract

The objective is to present and discuss the proposals and interests of Brazilian businessmen and international organizations in the reform of Brazilian professional education in the 1990s. This is a qualitative research of documentary and bibliographic approach. The documents emanated by these institutions in the 1990s were analyzed in light of Gramsci's (1991) concepts of state; Harvey's, flexible capital accumulation (1992); and Marx's, work (1971). The documents analyzed promoted a consensus in the national educational context and served as a reference for the proposal of reforms in the Brazilian educational system that started to prioritize a general, flexible, polyvalent formation.

Keywords: History of professional education. Public Educational Policies. Flexible Accumulation of Capital.

1 Mestre em Educação, Doutorando em Educação do Programa de Pós-Graduação em Educação da Universidade Católica Dom Bosco (PPGE-UCDB). Bolsista de Doutorado da Coordenação de Aperfeiçoamento de Pessoal de Nível Superior (CAPES). Membro do Grupo de Pesquisa Políticas de Formação e Trabalho Docente na Educação Básica, vinculado ao PPGE/UCDB/MS, e do Grupo de Pesquisa Políticas Públicas Educacionais no âmbito da Educação Básica, vinculado ao PPGE/UCB/DF. Endereço profissional: Av. Tamandaré, 6000, Bloco D - Jardim Seminário - Campo Grande/MS. Cep. 79117-900, Tel. (67) 3312.3597, E-mail:<adodavi@gmail.com>.

2 Doutora em Educação. Pós-Doutoranda no Instituto de Educaçáo da Universidade Federal de Mato Grosso (UFMT). Docente do Programa de Pós-Graduação em Educação da Universidade Católica Dom Bosco (PPGE-UCDB). Coordenadora do Grupo de Pesquisa Políticas de Formação e Trabalho Docente na Educação Básica, vinculado ao PPGE/UCDB/MS, e do Grupo de Pesquisa Políticas Públicas Educacionais no âmbito da Educação Básica, vinculado ao PPGE/UCB/DF. Endereço profissional: Av. Tamandaré, 6000, Bloco D - Jardim Seminário - Campo Grande/MS. Cep. 79117-900, Tel. (67) 3312.3597. E-mail: <celeidams@uol.com.br>.

\begin{tabular}{|l|l|l|l|l|l|} 
R. Educ. Públ. & Cuiabá & v. 28 & n. 67 & p. 169-191 & jan./abr. 2019
\end{tabular}




\section{Introdução}

Este trabalho se assenta no campo da história das políticas educacionais brasileiras e oferece uma discussão sobre os interesses de organismos internacionais e grupo de empresários nacionais em estimular a reforma do sistema educativo brasileiro, em específico, da educação profissional na década de 1990. Com intuito de entender a formação do consenso que dominou as discussóes acerca das políticas educacionais brasileiras na década de 1990, focamos nossos estudos na Conferência Mundial de Educação para Todos, realizada em Jomtien (1990); no Relatório de Jacques Delors, em Educação: um tesouro a descobrir (DELORS, 1998); no documento Educação Básica e Formação Profissional: uma visão dos empresários (EBFP), publicado pela Confederação Nacional da Indústria (CNI), em 1993, e no documento Prioridades e Estratégias para a Educação, publicado pelo Banco Mundial, em 1995. Avaliamos que as citadas obras fazem parte de aparatos hegemônicos de dominação capitalista.

Os documentos aqui estudados estâo intimamente ligados ao incentivo de uma formação educacional voltada para maximizar a produtividade, pelo investimento no capital humano. A alusão a esses documentos internacionais torna-se importante, porque serve de base para a implementação de reformas no sistema educativo de países em desenvolvimento na América Latina e Caribe, a chamada cartilha neoliberal. No caso dos documentos emanados pela CNI, destacamos Educação básica e formação profissional: uma visão dos empresários (EBFP), pois o seu conteúdo traz inovaçôes em relação às reformas educacionais voltadas às demandas da produção flexível no Brasil.

O que se vê na década de 1990, é a adoção, por parte do Banco Mundial, das conclusóes da Conferência Internacional de Educação para Todos, realizada em Jomtien em 1990, a qual se tornou base para a elaboração de suas diretrizes políticas para as próximas décadas, culminando, em 1995, com a publicação do documento Prioridades y Estratégias para La Educación, que foi uma análise sobre a educaçáo que estabeleceu como prioridade e estratégia a celeridade dos países para reformarem seus sistemas educacionais, visando à universalização da educação e ao aumento da qualidade e equidade, com objetivo de vincular a educação às demandas de uma economia marcada por uma produção flexível. Nesse sentido, afirma que: "Em primeiro lugar, a educação deve ser concebida para satisfazer a crescente demanda por parte da economia, de trabalhadores adaptáveis, capazes de adquirir facilmente novos conhecimentos." (BANCO MUNDIAL, 1995, p. 7).

O Banco Mundial tornou-se, nos últimos anos, o organismo internacional de maior visibilidade no cenário educacional global. E, em grande parte, ocupando 
o espaço tradicionalmente atribuído à Organização para a Educação, à Ciência e à Cultura das Naçôes Unidas (UNESCO), agência da Organização das Naçóes Unidas (ONU), especializada em educação (TORRES, 1997, p. 3). Em nível internacional, esse Banco é a maior fonte de conselhos sobre a política educacional e fundos externos para esse setor.

Frigotto (2008, p. 10) diz que a educação tem um papel fundamental para a evoluçáo do capitalismo, promovendo desigualdades entre as naçóes e grupos sociais. Essa materialização ocorre por meio da educação profissional, internalizando nos seus frequentadores que, para eles conseguirem um emprego, precisam se tornar cidadáos produtivos, adaptados, adestrados e treinados. E, assim, a educação acaba sendo caracterizada "pelo viés economicista, fragmentário e tecnicista".

Nesta pesquisa, entendemos trabalho como categoria ontológica e econômica fundamental que não pode se reduzir a fator, assim como a educação também não pode ser a isso reduzida. Concebemos educação como uma prática social, uma atividade humana e histórica que se define no conjunto das relaçóes sociais, no embate dos grupos ou classes sociais, sendo forma específica de relação social.

Essa pesquisa é qualitativa, de abordagem documental e bibliográfica na qual utilizamos os conceitos de estado, de Gramsci (1991); acumulaçáo flexivel do capital, de Harvey (1992); e trabalho, de Marx (1971), para subsidiar as análises das categorias consenso, hegemonia, trabalho e educaçáo profissional.

\section{Acumulação flexível no Brasil e as propostas e influências do empresariado nacional e de organismos internacionais para educação profissional na década de 1990}

Entendemos que as diferentes articulaçóes entre a educação e o trabalho, a partir da década de 1970, se deram no contexto da fase de acumulação flexível do capital e que o Estado, no âmbito federal e estadual, tem mediado as demandas por formação de força de trabalho para o mercado requeridas por empresários dos diversos ramos da economia, assim como as demandas por formação técnica de nível médio pelos jovens. Essa mediação vem se dando por meio do sistema educacional de ensino, na modalidade Educação Profissional.

A passagem de um modelo de acumulação rígida taylorista/fordista para o modelo de acumulação flexível, com a introdução de novos modelos de produção exigiu um esforço "no sentido de adequar e submeter às forças de trabalho aos seus imperativos." (DEITOS, 2008, p. 242). O trabalhador foi moldado nos padróes 
fordista e taylorista, em que a produção em série e o controle das atividades por tempo não atendiam aos interesses de uma produçáo calcada nos requisitos da flexibilidade, exigindo, na concepção e execução da tarefa, a participação ativa do trabalhador no processo produtivo. Assim, o regime de acumulação flexível é um confronto direto com a rigidez do fordismo, conforme a seguir se explica:

Ela [a acumulação flexível] se apoia na flexibilidade dos processos de trabalho, dos produtos e dos padróes de consumo. Caracteriza-se pelo surgimento de setores de produção inteiramente novos, novas maneiras de fornecimento de serviços financeiros, novos mercados e, sobretudo, taxas altamente intensificadas de inovação comercial, tecnológica e organizacional. (HARVEY, 1992, p. 140).

A formação profissional entendida como necessária ao novo trabalhador supera a ideia da formação ligada exclusivamente ao posto de trabalho para atender uma formação mais generalista, que permita ao trabalhador adaptarse a diversas possibilidades de trabalho em ambientes mais flexíveis. Nesse sentido, organismos internacionais como o Banco Mundial (BM), que financiam projetos sociais em países da América Latina e Caribe, mostram textualmente a importância que atribuem à educação básica. Em 1995, esse organismo publica um documento intitulado Priorits and strategies for educación: a world bank sector rewiew, estabelecendo suas prioridades e estratégias para investimento na educação e apontando para uma formação mais polivalente, adaptável aos novos modelos de organização produtiva flexível.

A educaçáo básica proporciona o conhecimento, as habilidades e as atitudes essenciais para funcionar de maneira efetiva na sociedade sendo, portanto, uma prioridade em todo lugar. Esses atributos inclui um nível básico de competência em áreas gerais tais como as habilidades verbais, computacionais, comunicacionais e a resoluçáo de problemas. Essas competências podem ser aplicadas a uma grande variedade de empregos e permitir as pessoas adquirir habilidades e conhecimentos específicos orientados para o trabalho, quando estiverem no local de trabalho. Em geral esse nível básico inclui cerca de oito anos de escolaridade. De fato, em alguns países, o primeiro ciclo de educação secundária está sendo combinado com a educação de primeiro grau para 
conformar uma etapa de educação obrigatória conhecida como "educação básica”. (BM, 1995, p. 63).

As novas normas de organização produtiva trouxeram novas exigências para a qualificação da força de trabalho. "A flexibilidade faz apelo ao savoir-faire e à competência da força de trabalho e, particularmente, à sua capacidade de dominar diferentes segmentos de um mesmo processo produtivo." (PAIVA, 1989, p. 21). A polivalência da força de trabalho torna-se o objetivo maior do sistema formativo requerido pelo capital, nesse sentido os organismos internacionais e os setores empresariais nacionais e internacionais se organizam para fazer valer a força do capital sobre o trabalho.

No ano de 1993, a CNI publica um documento intitulado Educação básica e formação profissional: uma visão dos empresários, em que atesta a importância que o sistema industrial dá ao capital humano, considerando-o como insumo básico para o desenvolvimento científico e tecnológico. Os empresários concluíram sobre a necessidade de se ajustar a formaçáo profissional, ou seja, de força de trabalho, pelos "avanços tecnológicos e de reorganização e gestão da produção, introduzido nos processos de trabalho na era da acumulação flexível." (IGNÁCIO, 2015, p. 116). Nesse documento, a CNI atesta:

Já não é possível que o indivíduo invista um grande período de tempo na educação e na formação profissional, com a intenção de adquirir um fundo de conhecimento ou de qualificaçáo que seja suficiente para toda a sua carreira. A educação recebida pelos jovens deve ter uma base sólida, que facilite constantes aquisiçóes e atualização de conhecimento para o resto de sua vida produtiva. (CNI, 1993, p.10).

No documento EBFP, a CNI destaca que o modelo de investimento em automação para superar as deficiências do sistema educacional não atendia mais as necessidades do novo paradigma industrial baseado na produção flexível e flexibilização com ampla capacidade de adaptação às mudanças. "Isso significa que a integração com a contemporaneidade do mundo implica maior desenvolvimento e apropriação da ciência e tecnologia, enquanto principais instrumentos da dinâmica do sistema produtivo moderno." (CNI, 1993, p. 13). Ou seja, estava superada a estratégia de contratar operários menos qualificados para diminuir os custos com pessoal. A CNI destaca que "na nova economia a busca simultânea da produtividade e de altos padróes competitivos requer que as pessoas sejam tratadas como bens a serem incrementados para que se lhes possa adicionar valor, em oposição a custos que devem ser reduzidos." (CNI, 1993, p. 13). 
Essa estratégia de investimento na pessoa não é uma preocupação social dos empresários com seus funcionários, mas sim uma prática baseada na teoria do capital humano ${ }^{3}$, elaborada no contexto das teorias do desenvolvimento no cerne dos centros mais adiantados do capitalismo monopolista, que "disseminouse, e foi em passo acelerado absorvida pelos países do terceiro mundo", aponta Frigotto (2003, p.19). Muito se deve ao fato de o Banco Mundial exigir dos países tomadores de empréstimo que reformassem seus sistemas educativos, atendendo as sugestóes dos organismos internacionais para adaptar sua formação de força de trabalho aos novos ditames da fase de acumulaçáo flexível do capital. O investimento no fator humano passa a significar um dos determinantes básicos para o aumento da produtividade e elemento de superação do atraso econômico. Do ponto de vista macroeconômico, constitui-se no fator explicativo das diferenças individuais de produtividade e de renda e, consequentemente, de mobilidade social (FRIGOTTO, 1984, p. 39).

Para Melo (2010, p. 65), deve-se analisar as aspiraçóes do empresariado industrial brasileiro constantes no documento EBFP articulado com um projeto societário funcionalista, no qual se prioriza a ênfase "na educaçáo básica, na formação de habilidades genéricas para os trabalhadores e a sua inserção como elemento para a competitividade", o que configura uma teoria do capital humano adaptada à fase de acumulação, produção e gestão flexível, nas quais "desigualdade se transforma em diferença", e as "classes sociais são substituídas pelo acento nas subjetividades" (2010, p. 65). As interpretaçóes de Melo (2010) apontam para a formação de um trabalhador preocupado apenas com seus interesses e arredio ao entendimento de classe, adaptável aos interesses da empresa. Nesse sentido, o projeto educativo do empresariado brasileiro se afasta de uma educação transformadora que possibilite à pessoa a superação de uma formação meramente instrumentalista para o atendimento das demandas por força de trabalho.

$\mathrm{O}$ interesse dos empresários industriais no sistema educativo nacional visa a alcançar padróes produtivos que garantam competitividade para a indústria; em consequência, com relação ao fortalecimento da economia, à geração de empregos e ao desenvolvimento social; por essa ótica, os interesses da CNI vão além de "um projeto de uma classe e se transforma em projeto de toda a sociedade" (MELO, 2010, p. 65). Para garantir essa transformação na sociedade, os empresários defendem a universalização da educação básica, alinhada com as orientaçôes originadas da Conferência de Jomtien/1990 e

3 Para o estudo da Teoria do Capital Humano é fundamental consultar a obra de Theodore Schultz, O valor econômico da educação (1963). No Brasil, Gaudêncio Frigotto em Educação e capitalismo real (2003). 
complementada pela educação profissional. Nesse documento, EBFP/1993 defende uma reforma curricular baseada em três eixos: "flexibilidade no saber; interdisciplinaridade do conhecimento; construção, pelo indivíduo, de uma visão globalizante dos processos tecnológicos, com ênfase na abstração, na apropriação de mecanismos lógicos e na transformação da maneira de pensar e construir conceitos." (CNI, 1993, p. 17).

A proposta dos empresários privilegia a aquisição de métodos de aprender em detrimento dos conteúdos a serem aprendidos. Interessante notar que um dos pilares da educação para o século XXI estabelecidos pela Organização das Naçóes Unidas para a Educaçáo, a Ciência e a Cultura (UNESCO) coaduna com os desejos do capital industrial, que é transformar a educaçáo básica em ferramenta que permita a pessoa adquirir capacidades de aprender métodos que possibilitem acompanhar as rápidas mudanças que a evolução tecnológica imprime ao mundo do trabalho. Ou seja, o aprender a aprender por toda vida, do qual decorre que "o trabalhador se capacite constantemente, e que sua formação básica seja direcionada para esta flexibilidade, que deverá incorporar para alavancar sua carreira." (MELO, 2010, p. 67).

A reforma curricular ocorrida na década de 1990, pautou-se numa formação humana baseada no saber fazer, que dispensa grandes conhecimentos teóricos, pois o currículo centralizou-se na noção de competência como modal da formação da força produtiva. Significa dizer que a prática se torna a referência do início e do fim do processo educativo, melhor adaptando o futuro trabalhador as novas formas de produção flexível. Esse modelo exige formação genérica e polivalente que insira o jovem no mundo da tecnologia e que consiga acompanhar as evoluçóes promovidas pelo avanço da tecnologia.

Sadri (2008, p. 267) defende que os avanços tecnológicos garantidos pelas intensas pesquisas promoveram uma espécie de "revolução do conhecimento". As reformas do currículo abarcadas nos PCNEM (1999, p. 15) indicam que o avanço da informática deve ser acompanhado pela educaçáo básica, pois "é possível afirmar que, nas próximas décadas, a educação vá se transformar mais rapidamente do que muitas outras, em função de uma nova compreensão teórica do papel da escola, estimulada pela incorporaçáo das novas tecnologias.”

A reforma curricular pretendida pelos empresários tem vinculação com as orientaçôes da universalização da educação básica presentes na Declaração de Jomtien (1990), adotada pelo Banco Mundial na orientação das políticas educacionais dos países da América Latina e Caribe, e foram elencadas nos PCNEM; que, por sua vez, contemplam as orientaçóes do relatório de Jaques Delors (1998). Essa reforma prioriza a flexibilização do currículo, privilegia a subjetividade, a interdisciplinaridade e a transdisciplinaridade adaptada ao modelo 
flexível de produção. Percebe-se o afastamento da valorização dos conteúdos presentes no modelo taylorista/fordista.

As orientaçôes do relatório de Delors (1998), intitulado Educação: um tesouro a descobrir, aponta a necessidade da educação acompanhar as transformaçóes da sociedade, pois "não há dúvida de que a capacidade individual de ter acesso e de tratar a informação vai ser um fator determinante para a integração da pessoa, não só ao mundo do trabalho, mas também, no seu ambiente escolar e cultural." (DELORS, 1998, p. 190). Defende ainda a adoção de um sistema de alternância, em que o jovem frequenta a escola regular e, em outro período, o mundo do trabalho, nesse sentido afirma:

Para tentar instaurar uma sociedade em que cada um possa aprender e continue a aprender ao longo de toda a sua vida é preciso repensar as relaçôes entre os estabelecimentos de ensino e a sociedade, assim como a sequência dos diferentes níveis de ensino. No ensino, como na vida ativa, futuramente, os percursos serão necessariamente menos lineares, com períodos de estudo alternando com períodos de trabalho. Estes avanços e recuos devem ocupar um lugar cada vez mais importante na sociedade, graças a novas formas de certificação, a uma passagem mais fácil de um tipo ou de um nível de ensino para outro, e a separações menos estritas entre educação e trabalho. (DELORS, 1998, p. 122-123).

Alguns fatores denotam a sujeição das políticas educacionais aos interesses do capital e, em determinados períodos, esses fatores são determinantes. "Nessa perspectiva a educação e a formação humana terão como sujeito definidor as necessidades, as demandas do processo de acumulação do capital sob as diferentes formas históricas de sociabilidade que assumir." (FRIGOTTO, 2003, p. 30). O que significa dizer que estão reguladas e subordinadas pela esfera privada e a sua reprodução.

O documento produzido e publicado pelo Banco Mundial, em 1990, Relatório sobre o Desenvolvimento Mundial, fez um levantamento da pobreza no mundo, traçando algumas medidas para atenuar essa condição, dentre as quais: deve-se "[...] ampliar e aperfeiçoar a educação primária e o atendimento médico básico" (BANCO MUNDIAL, 1990, p. 84).

Um dos motivos para se priorizar a educação básica, chamada de primária pelo Banco Mundial, parte do entendimento de que se investindo nessa etapa de ensino os governos reduzam a pobreza, "aumentando a produtividade do 
trabalho dos pobres, reduzindo a fecundidade, melhorando a saúde, e dota as pessoas de atitudes de que necessitam para participar plenamente na economia e na sociedade." (SHIROMA, MORAES, EVANGELISTA, 2002, p. 74-75). Significa dizer que investir em saúde e educação básica é investir em capital humano, ou seja, eleva os níveis de produção.

Sobre os resultados que a educação promove na produtividade das empresas e da necessidade de mudanças políticas nos países em desenvolvimento, o Banco Mundial destaca:

Educação aumenta a produtividade no mercado doméstico e permite adquirir mais informação; educação melhora a capacidade de aprender. Mas, para colher os benefícios de investimentos em educação precisa aumentar as oportunidades de aprendizagem produtivas através de inovações técnicas e mudanças nos regimes políticos e de mercado. (BANCO MUNDIAL, 1995, p. 28).

Analisando a proposta do Banco Mundial (1995) a partir do olhar de Torres (1997), podemos evidenciar os seguintes elementos: prioridade depositada sobre a educação básica; melhoria da qualidade e da eficácia da educação como eixo da reforma educativa; prioridade sobre os aspectos financeiros e administrativos da reforma educativa, dentre elas, descentralização e instituições escolares autônomas e responsáveis por seus resultados, porém os governos devem manter centralizadas apenas quatro funçóes: a de fixar padróes; a de facilitar os insumos que influenciam o rendimento escolar; a de adotar estratégias flexíveis para a aquisição e uso de tais insumos e a de monitorar o desempenho escolar, convocaçáo para uma maior participação dos pais e da comunidade nos assuntos escolares; impulso para o setor privado e organismos não governamentais como agentes ativos no terreno educativo, tanto nas decisóes como na implementação; mobilização e alocação eficaz de recursos adicionais para a educação como temas principais do diálogo e da negociação com os governos; adoção de um enfoque setorial; definição de políticas e estratégias baseadas na análise econômica.

Nesse sentido, o Brasil é obrigado, por ser financiado por esse organismo internacional, a "mobilizar as forças políticas necessárias para a produção do consenso, tendo em vista a realizaçáo do projeto internacional" (SHIROMA, MORAES, EVANGELISTA, 2002, p. 63), mobilizando, para isso, diversas representaçóes da sociedade civil e política para patrocinar essas reformas e alinhar o sistema educacional brasileiro com as recomendaçóes dos organismos internacionais. Especificamente para a educação profissional, o Banco Mundial (1995) defende que "a educação profissional dá melhores resultados quando conta 
com a participação direta do setor privado em sua administração, financiamento e direçáo". Isso indica o estreitamento dos laços do ensino com o setor produtivo, "fomentando os vínculos do setor público com o privado como a estratégia de base para a meta de equidade e eficiência no treinamento profissional." (SHIROMA, MORAES, EVANGELISTA, 2002, p. 62).

Interpretando essas contradiçóes e movimento histórico à luz de Harvey (1992, p. 178), "as provas de uma crescente flexibilidade (subcontratação, empregos temporários e atividades autônomas etc.) em todo o mundo capitalista são simplesmente demasiado claras." Para que essa flexibilidade seja produzida e reproduzida pelas escolas, fábricas, comércio, pela sociedade, faz-se necessário um convencimento ideológico, o qual acontece em correlação de forças entre as classes $^{4}$ para o estabelecimento de uma hegemonia dominante.

O aparato hegemônico dos organismos internacionais e do grupo organizado de empresários nacionais exerceu forte influência no sentido de estabelecer um consenso necessário para que a correlação de forças, em última instância, exercida pela sociedade jurídica fizesse prevalecer os interesses desse discurso hegemônico. Sobre o exercício da hegemonia Gramsci (2002), afirma que:

O critério metodológico sobre o qual deve se basear o próprio exame é esse: a supremacia de um grupo social se manifesta de dois modos, como "domínio" e como "direção intelectual e moral”. Um grupo social domina os grupos adversários, que visa a "liquidar" ou a submeter inclusive com força armada, e dirige grupos afins e aliados. Um grupo social pode e, aliás, deve ser dirigente já antes de conquistar o poder governamental (esta é uma das condições principais para a própria conquista do poder); depois, quando exerce o poder e mesmo se o mantém fortemente nas mãos, torna-se dominante mas deve continuar a ser também "dirigente". (GRAMSCI, 2002, p. 62-63).

Para Gramsci (2014), o convencimento ideológico se dá com a construção do consenso, o qual perpassa pela construção e manutenção da hegemonia. No caso citado, as fraçóes de classes burguesas, em certos momentos, incorporam os desejos democráticos das massas e dos organismos que vão difundir sua ideologia, a qual liga a estrutura e superestrutura, o que mantém o bloco histórico, que é

4 “[...] a classe que é a força material dominante da sociedade é, ao mesmo tempo, sua força espiritual. A classe que tem à sua disposição os meios de produção material dispóe, ao mesmo tempo, dos meios de produção espiritual, o que faz com que a ela sejam submetidas, ao mesmo tempo e em média, as ideias daqueles aos quais faltam os meios de produçáo espiritual.” (MARX, ENGELS, 2007, p. 47). 
"a identificação entre o conteúdo econômico-social [estrutura] e a forma éticopolítica [superestrutura].” (GRAMSCI, 2014, p. 308).

Ainda em Gramsci (2014), dizemos que a sociedade civil está ligada organicamente à sociedade política e são planos da superestrutura. No dizer de Gramsci:

[...] o que pode ser chamado de 'sociedade civil' (isto é, o conjunto de organismos designados vulgarmente como 'privados') e o da 'sociedade política' planos que correspondem, respectivamente, à função de 'hegemonia' que o grupo dominante exerce em toda a sociedade e àquela de 'domínio direto' ou de comando, que se expressa no Estado e no governo 'jurídico’. (GRAMSCI, 1987, p. 21).

Sob essa ótica, Gramsci estabelece sua concepção de Estado, como "todo o complexo de atividades práticas e teóricas com as quais a classe dirigente justifica e mantém não só o seu domínio, mas consegue obter o consentimento ativo dos governados." (GRAMSCI, 1991, p. 91). É sob essa ótica de Estado que percebemos e entendemos que o discurso hegemônico dos que defendiam uma reforma na educação profissional brasileira prevaleceu nessa década de 1990 .

Ainda sobre a hegemonia, Frigotto (2005) afirma que no contexto brasileiro a classe hegemônica é orientada pelas teorias neoliberais, planejadas para os países da América Latina e Caribe pelos Organismos Internacionais, destacadamente o $\mathrm{FMI}^{5}$, Banco Mundial e UNESCO ${ }^{6}$, que defendiam que a economia náo deveria ser regulada por políticas estatais e sim pelo mercado e as leis da demanda e da procura, da livre concorrência, da competição, do individualismo e da maior produtividade com o mínimo de custo.

No ano de 1996, finalmente foi sancionada a Lei Federal no 9.394, que estabelece as Diretrizes e Bases da Educação Nacional (LDBN), dispondo em seu Art. 39 que a "educação profissional, integrada às diferentes formas de educação, ao trabalho, à ciência e à tecnologia, conduz ao permanente desenvolvimento de aptidōes para a vida produtiva." (BRASIL, 1996). Essa concepção, advinda dos documentos legais em vigor, atribui uma nova identificação à educação profissional, marcada pela superação do preconceito social que a desvalorizava ${ }^{7}$.

5 Fundo Monetário Internacional.

6 Organização das Naçōes Unidas para a Educação, Ciência e Cultura.

7 Parecer CNE/CEB n. ${ }^{\circ}$ 16/99. Trata das Diretrizes Curriculares Nacionais para a Educaçáo Profissional de Nível Técnico. Disponível em: <http://webcache.googleusercontent.com/search?q=cache:d2g-jMENPVIJ:portal.mec. gov.br/setec/arquivos/pdf_legislacao/rede/legisla_rede_parecer1699.pdf $+\& c d=1 \& \mathrm{chl}=\mathrm{pt}-\mathrm{BR} \& \mathrm{ct}=\mathrm{clnk} \& \mathrm{gl}=\mathrm{br}>$. Acessado em 10 julho de 2015. 
Na LDBN, a Educação Profissional passa a integrar a Educação Básica, como modalidade do Ensino Médio. Para Bremer e Kuenzer (2012, p. 6), "nesta nova proposta, a partir do reconhecimento das relaçóes entre trabalho, ciência e cultura; desta forma, pelo menos no texto legal, a dualidade entre educação geral e formação profissional estaria superada."

No governo Fernando Henrique Cardoso (1995-2002), houve uma reformulação na educaçáo profissional por meio do Decreto no 2.208/1997, assentado na noção da pedagogia das competências. Esse Decreto separava a educação profissional do ensino propedêutico. Para Bremer e Kuenzer (2012, p. 6), isso se deve à "acentuada dualidade, a partir dos arranjos flexíveis de competências diferenciadas para atender a uma demanda de qualificação puxada pela demanda do sistema produtivo."

Para Frigotto, Ciavatta e Ramos (2012, p. 25), o primeiro projeto de LDBEN propunha uma "formação profissional integrada à formação geral nos seus múltiplos aspectos humanísticos e científico tecnológicos", o que se tornou inviável a partir do Decreto no 2.208/1997 e da Portaria do MEC no 646/1997, que regulamenta a implantação do disposto nos Artigos 39 a 42 da Lei Federal no 9.394/1996. Na visão desses autores, esses dispositivos, além de proibirem a almejada formação integrada, regulamentavam "formas fragmentadas e aligeiradas de educação profissional em função das alegadas necessidades do mercado. O que ocorreu também por iniciativa do Ministério do Trabalho e Emprego, por meio de sua política de formação profissional.” (FRIGOTTO, CIAVATTA, RAMOS, 2012, p. 25).

Coadunamos com Frigotto, Ciavatta e Ramos (2005, p. 49) quando defendem um Ensino Médio que ofereça uma formação in tegral ou omnilateral "fundamentado em uma base comum e tendo como eixo estruturante o trabalho, a ciência, a tecnologia e a cultura, independentemente de ser ou não profissionalizante", pois esse modelo de ensino promove, em última instância, uma escola unitária, tendo em vista que a formação científica e cultural não ficam dissociadas do processo de ensino-aprendizagem, tampouco distingue uma escola para os filhos dos ricos e outra para os filhos dos pobres.

O entendimento de que uma formação integrada permite uma melhor relação do homem com a natureza, entendendo-a e transformando-a por meio do trabalho, nos dizeres de Saviani (2003), Frigotto, Ciavatta e Ramos (2005) advêm da proposta emancipatória de Marx (2010), para formar um novo entendimento de sociabilidade humana que vise a superar as injustiças e desigualdades decorrentes do processo de acumulação capitalista, assim como da sociedade de classes. Conforme Marx: 
[...] o homem se apropria de sua essência omnilateral de uma maneira omnilateral. Cada uma das suas relaçôes humanas com o mundo, ver, ouvir, cheirar, degustar, sentir, pensar, intuir, perceber, querer, ser ativo, amar, enfim todos os órgáos da sua individualidade, assim como os órgãos que são imediatamente em sua forma como órgãos comunitários. (MARX, 2010, p. 108).

O pensamento de formação integral defendido por Saviani (2003), Frigotto, Ciavatta e Ramos (2005) também decorre da teoria de Gramsci (2010) para a emancipação do homem por meio de uma escola unitária, que ofereça uma formação omnilateral. Nas palavras de Gramsci:

O advento da escola unitária significa o início de novas relaçóes entre o trabalho intelectual e trabalho industrial não apenas na escola, mas em toda vida social. O princípio unitário, por isso, irá se refletir em todos os organismos de cultura, transformando-os e emprestando-lhes um novo conteúdo. (GRAMSCI, 2010, p. 40).

Acreditamos que as políticas públicas de educação profissional e tecnológica (EPT) deveriam ser desenvolvidas nos moldes de uma formação omnilateral teorizada por Gramsci (2010) e Marx (2010). Coadunamos com Frigotto, Ciavatta e Ramos (2005), quando questionam:

Se a preparação profissional no ensino médio é uma imposição da realidade, admitir legalmente essa necessidade é um problema ético. Não obstante, se o que se persegue não é somente atender a essa necessidade, mas mudar as condiçôes em que ela se constitui, é também uma obrigação ética e política, garantir que o ensino médio se desenvolva sobre uma base unitária para todos. Portanto, o ensino médio integrado ao ensino técnico, sob uma base unitária de formação geral, é uma condição necessária para se fazer a "travessia" para uma nova realidade. (FRIGOTTO, CIAVATTA, RAMOS, 2005, p. 49).

"Um projeto de ensino médio integrado ao ensino técnico, tendo como eixo o trabalho, a ciência e a cultura, deve buscar superar o histórico conflito existente em torno do papel da escola de formar para a cidadania ou para o trabalho produtivo." (RAMOS, 2012, p. 107). 
Nesse aspecto, observamos o avanço das relaçóes capitalistas de produção no seio do Estado, o que favoreceu a valorização do conhecimento técnico e científico, tornando a escola uma instituição voltada a formar para a cultura industrialista (GRAMSCI, 1991).

A correlação de forças entre as demandas dos trabalhadores por qualificação, assim como as demandas por trabalhadores qualificados para alimentar o sistema produtivo, pressiona o Estado a legislar. A legislação pode ser visualizada como um artifício; que, embora não responda de modo inequívoco às demandas sociais, resulta da correlação de forças que predominam em um contexto social e político.

Exemplo dessa correlação de forças é observado por Oliveira (2002), que destaca o posicionamento do Banco Mundial frente aos investimentos públicos em cursos técnicos na Rede Federal de Educação Profissional e Tecnológica, considerando-os muito dispendiosos. Essa autora afirma que "os custos do ensino médio integrado ao técnico, foram considerados muito altos para serem arcados pelo poder público.” (2002, p. 57). Os esforços federais para reduzir os custos com o Ensino Médio também foram imperativos para a efetivaçáo do Decreto $n^{\circ}$ 2.208/1997.

No dizer dessa autora:

É possível mesmo inferir que, mesmo não sendo a razão principal, a possibilidade de barateamento do ensino médio pode ter contribuído para a urgência atribuída pelo poder executivo atribuído a reforma da educação profissional, desrespeitando as discussóes que se realizavam no movimento dos trabalhadores dos CEFETs e demais escolas técnicas [...] (OLIVEIRA, 2002, p. 57-58).

O Decreto no 2.208/1997 regulamenta o parágrafo $2^{\circ}$ do Art. 36 e os Artigos 39 a 42 da LDBEN, Lei no 9.394/1996. Como já foi dito, separou o ensino técnico do propedêutico, o que significa dizer que a conquista de uma educação unitária aprovada na LDBEN n. 9.394/1996 já sofrera sua primeira mudança. Pela determinação do MEC, não poderiam mais ser ofertados cursos de Ensino Médio integrados à educação profissional.

No Art. $5^{\circ}$ do Decreto ${ }^{\circ}$ 2.208/1997, retoma-se a dualidade histórica da educação brasileira, o que em certa medida perpetua a divisão social do trabalho, visto que pela educação propedêutica, prepara-se para a intelectualidade, e pela educação profissional, prepara-se o jovem para o ingresso no mercado de trabalho. Textualmente, assevera: "A educação profissional que prepara o jovem para ingressar no mundo do trabalho, educação profissional de nível técnico terá organização curricular própria e independente do ensino médio, podendo ser oferecida de forma concomitante ou sequencial a este." (BRASIL, 1997). 
Kuenzer (2006, p. 887) destaca que o Decreto $n^{\circ} 2.208 / 1997$ significou o suporte jurídico necessário para a execução de um programa de formação profissional originado de um acordo entre Banco Mundial e o MEC, chamado Plano Nacional de Qualificação do Trabalhador (PLANFOR). Essa autora destaca que os investimentos do PLANFOR foram realizados em cursos de curta duraçáo que não agregam qualidade à educação.

Não temos a intenção aqui de analisar o PLANFOR, mas sim de percebermos como a proposta do Banco Mundial, de desvinculação da formação profissional com o Ensino Médio, foi atendida pelo Decreto n ${ }^{\circ} 2.208 / 1997$, e como ocorreu a priorização da qualificação profissional executada em instituiçóes privadas de ensino. "Os cursos rápidos, sem regulamentação, sem pré-requisitos de escolaridade e pagos, oferecidos no âmbito do PLANFOR, são uma forma precária de acesso à uma formação profissional para a maioria da classe trabalhadora." (MELO, 2010, p. 77). Isso foi possibilitado pelo texto do Art. $3^{\circ}$ do mesmo Decreto, que dividiu a educação profissional em três níveis, criando o nível básico, o qual não necessitaria de qualquer escolaridade prévia, como segue: "A educação profissional compreende os seguintes níveis: I - básico: destinado à qualificação, requalificação e reprofissionalização de trabalhadores, independente de escolaridade prévia; II técnico: [...]; III - tecnológico: [...]" (BRASIL, 1997).

Em consonância com a cartilha neoliberal, da qual os países da América Latina são caudatários, o governo de Fernando Henrique Cardoso (1995-2002) efetivou a descentralizaçáo da administraçáo com a reforma do aparelho institucional, igualmente em busca de eficiência na gestão da educação. Não por acaso foram efetivadas reformas, também, nos currículos do Ensino Médio e Profissional. Primeiro, foram as Diretrizes Curriculares Nacionais do Ensino Médio (DCNEM), estabelecidas pelo Parecer CNE/CEB n ${ }^{\circ}$ 15/1998; depois, as Diretrizes Curriculares Nacionais da Educação Profissional Técnica de Nível Médio (DCNEP), estabelecidas pelo Parecer CNE/CEB no 16/1999, ambas sob forte influência do relatório de Jaques Delors (1998), o qual aponta quatro supostos imperativos para a educação, ou como consta no relatório, "quatro pilares da educação: aprender a conhecer, aprender a fazer, aprender a conviver e aprender a ser" (DELORS, 1998, ).

Para Ciavatta e Ramos (2012, p. 17), as DCNEM/1998 e as DCNEP/1999, "ambas baseadas em competências, tiveram como fundamento os princípios axiológicos expostos nas respectivas diretrizes, na verdade, uma releitura desses pilares." Nas DCNEM, o Art. $4^{\circ}$ do Parecer CNE/CEB no 15/1998, assevera que: "as propostas pedagógicas das escolas e os currículos constantes dessas propostas incluirão competências básicas, conteúdos e formas de tratamento dos conteúdos, previstas pelas finalidades do ensino médio estabelecidas pela lei." (BRASIL, 1998). Já na DCNEP/1999, Parecer no 16/1999, o modelo das competências torna-se mais explícito, como segue: 
As características atuais do setor produtivo tornam cada vez mais tênues as fronteiras entre práticas profissionais. Um técnico precisa ter competências para transitar com maior desenvoltura e atender às várias demandas de uma área profissional, não se restringindo a uma habilitação vinculada especificamente a um posto de trabalho. (BRASIL, 1999, p. 112).

O estímulo à polivalência expresso nas DCNEP/1999 visa a formar um novo perfil de trabalhador requerido pelas demandas do sistema de produção flexível, versadas nas recomendaçóes presentes nos documentos do Banco Mundial (1995) e CNI (1993).

Ainda explorando a ênfase no modelo de competências, consta no Parecer no 16/1999: "o mundo do trabalho está se alterando contínua e profundamente, pressupondo a superação das qualificaçóes restritas às exigências de postos delimitados, o que determina a emergência de um novo modelo de educação centrado em competências por área.” (BRASIL, 1999, p. 113).

Essa reforma na educação profissional reforça que “a principal finalidade da educação contemporânea seria a formação de personalidades flexíveis para a adaptação à realidade instável e incerta.” (CIAVATTA, RAMOS, 2012, p. 17). Percebe-se que o sistema capitalista promove sua reestruturação produtiva e submete os países de economia dependente às reformas que julgam necessárias para acompanhar a produção, distribuição e comercialização. Consequentemente, a reforma curricular no Brasil faz parte do processo de adaptação do seu sistema educativo à formação de força de trabalho flexível.

Desde as discussóes acerca do Projeto de Lei que deu origem à Lei no 9.394/1996, os representantes do empresariado vinham tencionando o Governo Federal para que a legislação educacional brasileira atendesse aos interesses do sistema produtivo que exigia uma formação mais flexível baseada no princípio das competências ${ }^{8}$. Como exemplo, a desvinculação da formação profissional da educação básica.

8 A qualificação tem sido tensionada pela noção de competência, em razão do enfraquecimento de suas dimensōes conceitual e social, em benefício da dimensão experimental. A primeira porque os saberes tácitos e sociais adquirem relevância diante dos saberes formais, cuja posse era normalmente atestada pelos diplomas. A segunda porque, em face da crise do emprego e da valorizaçáo de potencialidades individuais, as negociaçōes coletivas antes realizadas por categorias de trabalhadores passam a se basear em normas e regras que, mesmo pactuadas coletivamente, aplicam-se individualmente. A dimensão que se sobressai nesse contexto é a experimental. A competência expressaria coerentemente essa dimensão, pois, sendo uma noção originária da psicologia, ela chamaria a atenção para os atributos subjetivos mobilizados no trabalho, sob a forma de capacidades cognitivas, sócio afetivas e psicomotoras (RAMOS, 2002, p. 402). 
As principais reformas ocorridas no sistema educativo brasileiro na década de 1990 alinharam formação de força de trabalho aos imperativos da fase de acumulação flexível do capital, conduzida pelo capital internacional, representada pelos organismos internacional e localmente por representantes dos empresários. Essa ótica decorre de um modelo de Estado em que a hegemonia da classe dominante se torna presente nas políticas públicas, pois quando a sociedade civil elege seus representantes, eles passam a compor a sociedade política, que passa a dominar o aparato jurídico e coercitivo do Estado. É o que forma o Estado ampliado teorizado por Gramsci (1987).

No âmbito da política pública, esse investimento na qualificação do homem para o trabalho se dá por meio da educação profissional. Frigotto (2001) afirma que a valorização da educação profissional pelo governo vem sendo apontada, mais uma vez, como a melhor possibilidade de alinhar o Brasil à nova ordem mundial. Porém, não há espaço para todos, mas apenas àqueles que desenvolvem competências reconhecidas pelo mercado, para garantir não mais apenas o posto de trabalho e ascensão numa determinada carreira, mas a empregabilidade.

Com relaçáo ao significado da noção ampliada de trabalho, teorizada por Marx (1971), torna-se importante saber que "a expansão do trabalho em serviços, em esferas não diretamente produtivas, mas que muitas vezes desempenham atividades imbricadas com o trabalho produtivo, mostra-se como outra característica importante da noção ampliada de trabalho." (ANTUNES, 2006, p. 12). Na visão de Saviani (1996, p. 152), trabalho é "[...] o ato de agir sobre a natureza, adaptando-a as necessidades humanas." A partir dessa definição, é possível perceber o trabalho como essência humana, mostrando que para o homem continuar existindo a necessita de produzir sua própria existência pelo seu trabalho, fazendo com que sua vida seja determinada pelo modo que sua existência é produzida.

Antunes (2006) faz um diagnóstico do que vem acontecendo nas relações de produção no mundo contemporâneo, afirmando que:

[...] o que vem ocorrendo no mundo contemporâneo é uma maior inter-relação, maior interpenetração, entre as atividades produtivas $\mathrm{e}$ as improdutivas, entre as atividades fabris e de serviços, entre atividades laborativas e atividades de concepção, que se expandem no contexto da reestruturação produtiva do capital. Uma concepção ampliada de trabalho nos possibilita entender o papel que ele exerce na sociabilidade contemporânea, neste limiar do século que se inicia. (ANTUNES, 2006, p. 13). 
O entendimento acerca do conceito de trabalho de Antunes (2006) e Saviani (1996) tem origem no conceito desenvolvido por Marx, em O Capital, onde afirma que:

Antes de tudo, o trabalho é um processo de que participam o homem e a natureza, processo em que o ser humano, com sua própria ação, impulsiona, regula e controla seu intercâmbio material com a natureza. Defronta-se com a natureza como uma de suas forças. Póe em movimento as forças naturais de seu corpo - braços e pernas, cabeça e mãos -, a fim de apropriar-se dos recursos da natureza, imprimindo-lhes força útil à vida humana. Atuando assim sobre a natureza externa e modificando-a, ao mesmo tempo modifica a sua própria natureza. (MARX, 1971, p. 211).

O interesse da esfera privada em ter o Estado como aliado para promover a qualificação dos jovens, adaptando-os ao mundo do trabalho nessa fase de acumulação flexível do capital, se efetua por meio das políticas do Estado educador, teorizado por Gramsci (1991), o qual tem por finalidade "adequar a 'civilização' e a moralidade das mais amplas massas populares às necessidades de desenvolvimento continuado do aparelho econômico de produção, portanto, elaborar também fisicamente tipos novos de humanidade." (GRAMSCI, 1991, p. 91).

Sob esta ótica, Gramsci estabelece sua concepção de Estado, como "todo o complexo de atividades práticas e teóricas com as quais a classe dirigente justifica e mantém não só o seu domínio, mas consegue obter o consentimento ativo dos governados." (GRAMSCI, 1991, p. 91).

Para Ramos (2012), a sociedade civil presente apenas na estrutura econômica, ao estender sua atuação, passa a figurar na dimensão do Estado com a sociedade política e, essa última, com poder sobre os dispositivos jurídicos, passa a configurar o Estado stricto sensu ou governo. Assim "a concepção de estado então se amplia, juntamente com suas funçóes, que passam a ser hegemônicas revestidas de coerção e implica tanto a superestrutura política e jurídica, quanto a própria economia.' (RAMOS, 2012, p. 30).

No âmbito do Estado ampliado de Gramsci (1987), a sociedade política nacional, por meio do bloco hegemônico no poder, incorpora às Políticas de Educação Profissional concepçôes hegemônicas baseadas no princípio de competências, defendidas como fundamental pelo Banco Mundial e CNI para melhor adaptar à formação de força de trabalho para o mercado de produção mais flexível. Assim, documentos como a LDBEN no 9.394/1996, os Parâmetros Curriculares Nacionais (1999) e as Diretrizes Curriculares Nacionais para o 
Ensino Médio e para a Educação Profissional (1999) foram pensados levando em consideração uma educação fundamentada no princípio das competências.

A importância da escola como aparato contra-hegemônico aos ideais capitalistas é defendida por Gramsci (1991), que nos afirma:

[...] a escola é o instrumento para elaborar a hegemonia pelos trabalhadores, então, a escola deve ser disputada na direçâo de uma "escola única inicial de cultura geral, humanista, formativa, que equilibre com equanimidade o desenvolvimento da capacidade de trabalhar manualmente (tecnicamente, industrialmente) e o desenvolvimento das capacidades de trabalho intelectual. (GRAMSCI, 1982, p. 118).

Essas políticas públicas voltadas à educação profissional tornaram-se elemento importante na dimensão política e ideológica, servindo de estratégia da luta de classes; assim, a política do Estado vem garantindo a manutenção das relações de produção e divisão social do trabalho nessa fase de acumulação flexível do capital.

\section{Considerações Finais}

Esta pesquisa limitou-se a apresentar e discutir as propostas e interesses do empresariado nacional e dos organismos internacionais na reforma da educação profissional brasileira na década de 1990.

Os documentos elencados ao longo do texto contribuíram para a materialização de mudanças no sistema educativo brasileiro, alinhando formação de força de trabalho aos imperativos da fase de acumulação flexível do capital, conduzida pelo capital internacional representado, sobretudo, pela criação de um consenso via Banco Mundial e localmente pela CNI.

No Estado capitalista, o bloco no poder vem sendo determinante para a aceitação de demandas de organismos internacionais para formulação de políticas sociais que seguem os padrôes do modelo capitalista de produção, destacadamente o Banco Mundial, assim como demandas dos representantes dos empresários nacionais, sobretudo a Confederação Nacional da Indústria.

No bojo da fase de acumulação flexível do capital, os padrões de formação para o mundo do trabalho se constituem com um forte viés de polivalência e adaptabilidade à evolução dos processos tecnológicos, influenciando a introdução de princípios, como o das competências nos currículos da educação básica brasileira, sobretudo na década 1990 . 
O que se percebe na Proposta do Banco Mundial de 1995 é que os países em desenvolvimento devem promover reformas em seus sistemas educativos, adaptando-o aos ditames dos princípios neoliberais hegemônicos, ficando a educação diminuída à lógica de mercado, sob pena de não favorecer o desenvolvimento social do país, e diminuição da pobreza por não aderir a um consenso global de produção flexível.

\section{Referências}

ANTUNES, R. Adeus ao trabalho? Ensaio sobre as metamorfoses e a centralidade no mundo do trabalho. 11. ed. São Paulo: Cortez, 2006.

BANCO MUNDIAL. Relatório sobre o desenvolvimento mundial. World Bank, 1990.

Bank, 1995.

Prioridades y Estratégias para la Educación. Washington: World

BRASIL. Lei no 9.394 de 20 de dezembro de 1996. Estabelece as diretrizes e bases da educação nacional. Brasília, 1996. Disponível em: <www.planalto.gov. br/ccivil_03?leis/9394.htm>. Acesso em: 22 maio 2015.

. Decreto no 2208 de 17 de abril de 1997. Regulamenta o art. 36 e os artigos 39 a 42 da Lei no 9394/96. Diário Oficial da Uniáo, 18 de abril de 1997, seção 1, p. 7760.

. Conselho Nacional de Educação. Parecer CNE/CEB no 15, de $1^{\circ}$ de junho de 1998. Trata das Diretrizes Curriculares Nacionais para o Ensino Médio. Brasília: 1998.

. Conselho Nacional de Educaçáo. Parecer CNE/CEB no 16, de 5 de outubro de 1999. Trata das Diretrizes Curriculares Nacionais para a Educação Profissional Técnica de Nível Médio. Brasília: 1999.

BREMER, M. A. S. KUENZER, A. Z. Ensino médio integrado: uma história de contradiçôes. In: Anais do IX Seminário de Pesquisa em Educação da Regiáo Sul - ANPED SUL. Caxias do Sul/Rio Grande do SUL, 2012. Disponível em: <http://www.portalanpedsul.com.br/admin/uploads/2012/Trabalho_e_Educacao/ Trabalho/05_01_24_2217-6580-1-PB.pdf> Acesso em: 20 de dez. 2015.

CIAVATTA, M.; RAMOS, M. A “era das diretrizes”: a disputa pelo projeto de educação dos mais pobres. Revista Brasileira de Educaçáo, v. 17, n. 49, jan./abr. 2012. 
CONFEDERAÇÁO NACIONAL DA INDÚSTRIA. Educaçáo básica e formaçáo profissional: uma visão dos empresários. Rio de Janeiro, CNI, 1993.

CONFERÊNCIA Mundial de Educação para Todos. Declaração Mundial de Educaçáo para Todos. Plano de Ação para Satisfazer as Necessidades Básicas de Aprendizagem. Brasília, DF: UNIFEC, 1990.

DEITOS. Maria Lúcia de Melo. A formação do trabalhador num contexto de permanente mudança tecnológica. In: FIGUEREDO. I. M. Z.; ZANARDINI. I. M. S.; DEITOS. R. A. (Org.). Educaçáo, Política Social e Estado no Brasil. Cascavel: EDUNIOESTE; Curitiba: Fundação Araucária, 2008.

DELORS, J. Educação: um tesouro a descobrir. Relatório para a UNESCO da Comissão Internacional sobre Educação para o século XXI. São Paulo: Cortez; Brasília, DF: MEC: UNESCO, 1998.

FRIGOTTO, Gaudêncio. A produtividade da escola improdutiva. São Paulo: Cortez, 1984.

. Educaçáo e Crise do Capitalismo Real. 5. ed. São Paulo: Cortez, 2003.

Globalização e Crise do Emprego: Mistificaçóes e Perspectivas da Formaçáo Técnico-Profissional. Boletim Técnico do SENAC DN v. 2, n. 25, 2001.

. Concepçóes e Mudanças no Mundo do Trabalho e o Ensino Médio. Centro de Educação Tecnológica do Estado da Bahia, Bahia, 2008.

FRIGOTTO, G.; CIAVATTA, M.; RAMOS, M. N. A política de educação profissional no Governo Lula: um percurso histórico controvertido. Educaçáo \& Sociedade, Campinas, v. 26, n. 92, p. 1087-1113, out. 2005.

FRIGOTTO, Gaudêncio. CIAVATTA, Maria. RAMOS, Marise (Org.) Ensino médio integrado: concepções e contradiçôes. 3. ed. São Paulo: Cortez, 2012.

GRAMSCI, Antonio. Os intelectuais e a organizaçáo da cultura. Rio de Janeiro: Civilização Brasileira, 1991.

. Cartas do cárcere. 3. ed. Tradução de Noênio Spínola. Rio de Janeiro: Civilização Brasileira, 1987.

. Cadernos do cárcere. Rio de Janeiro: Civilização Brasileira, 2002, v. 5.

. Cadernos do Cárcere. Os intelectuais, O princípio educativo. v. 2, Rio de Janeiro: Civilização Brasileira, 2010. 
. Cadernos do Cárcere. V. 1. Introdução ao Estudo da Fisolofia. A filosofia de Benedetto Croce. v. 1, 7. ed. Rio de Janeiro: Civilização Brasileira, 2014. HARVEY, D. A condição pós-moderna. 6. ed. São Paulo: Edições Loyola, 1992. IGNÁCIO, Paulo César de. A acumulação flexível no Brasil e suas demandas de qualificação da força de trabalho. In: BATISTA, Eraldo Leme; MULLER, Meire Terezinha (Org.) Realidades da Educaçáo Profissional no Brasil. São Paulo: Ícone, 2015.

KUENZER, A. Z. A educação profissional nos anos 2000: a dimensão subordinada das políticas de inclusão. Educ. Soc., Campinas, v. 27, n. 96 - Especial, p. 877-910, out. 2006.

MARX, Karl. O Capital, Rio de Janeiro: Civilização Brasileira, Livro I, v. 1. 1971. . Crítica da filosofia do direito de Hegel. São Paulo: Boitempo, 2010

MARX, K.; ENGELS, F. A ideologia alemã. São Paulo: Boitempo, 2007.

MELO, Alessandro de. O projeto pedagógico da Confederaçáo Nacional da Indústria para a educaçáo básica nos anos 2000. Tese (Doutorado) - Universidade Federal do Paraná, Programa de Pós-Graduação em Educação, Curitiba, 2010.

OLIVEIRA, Dalila Andrade. O ensino médio no contexto das políticas para a educação básica. In: ZIBAS, Dagmar; AGUIAR, Márcia; BUENO, Maria. O ensino médio e a reforma da educaçáo básica . Brasília DF: Plano Editora, 2002. p. 47-69.

PAIVA, Vanilda. Produçáo e qualificação para o trabalho: uma revisão da bibliografia internacional. Textos de discussão do Instituto de Economia Industrial. Textos n. 216. Rio de Janeiro: IEI/UFRJ, 1989.

RAMOS, M. N. A Pedagogia das Competências: autonomia ou adaptação? 2. ed. São Paulo: Cortez, 2002.

RAMOS, Marise N. Possibilidades e Desafios na Organização do Currículo Integrado. In: RAMOS, Marise N.; FRIGOTTO, Gaudêncio; CIAVATTA, Maria. Ensino Médio Integrado: Concepção e Contradiçôes. São Paulo: Cortez, 2012, p. 106-127.

SADRI, Simone. Parâmetros Curriculares Nacionais Para o Ensino Médio e a Relação Tecnologia e Educação. In: FIGUEREDO. I. M. Z.; ZANARDINI. I. M. S.; DEITOS. R. A. (Orgs). Educação, Política Social e Estado no Brasil. Cascavel: EDUNIOESTE; Curitiba: Fundação Araucária, 2008. 
SAVIANI, Demerval. O Trabalho como Princípio Educativo Frente às Novas Tecnologias. In: FERRETTI, C. J. et al., (Org.). Novas Tecnologias, Trabalho e Educação: um debate multidisciplinar Rio de Janeiro: Vozes, 1996.

SAVIANI, Dermeval. O choque teórico da politecnia. Trabalho, educaçáo e saúde, v. 1, n. 1, p. 131-152, 2003.

SHIROMA, Eneida Oto; MORAES, Maria Célia Marcondes de; EVANGELISTA, Olinda. (Org.). Política educacional. Rio de Janeiro: Lamparina, 2002.

TORRES, Rosa María. Melhorar a qualidade da educação básica? As estratégias do Banco Mundial. In: TOMMASI, L. de; WARDE, J. M.; HADDAD, S. (Org.) O Banco Mundial e as políticas educacionais. São Paulo: Cortez/Ação EducativaPUC-SP, 1997. 



\section{Educação em Ciências e Matemática}





\section{Ciência escolar e ciência fora da escola: opiniões e interesses de jovens brasileiros \\ School and out-of-school science: opinions and interests of young brazilians}

Graciela S. OLIVEIRA ${ }^{1}$

Nelio BIZZO²

Resumo

Abstract

Buscou-se verificar as opinióes dos jovens brasileiros sobre a ciência escolar e o interesse pela ciência fora da escola. Houve a participação de 2.404 estudantes matriculados no $1^{\circ}$ ano do Ensino Médio de 78 escolas. As coletas de dados foram por meio de questionários e para as análises utilizou-se Software Statistical Package for Social Science (SPSS) - 18.0. Os resultados apontam que os estudantes reconhecem a importância das aulas de ciências e o seu papel no cotidiano, mas a proporção de interessados em aprofundar sobre temas científicos em outros espaços de informação é menor.

Palavras-chave: Atitude. Ensino Médio. Relevância da ciência.
The objective was to verify the opinions of youngsters on school science and interest in science outside of school. There was the participation of 2,404 students enrolled in the 1 st year of high school in 78 schools. Data collection was through questionnaires and the analysis was used software Statistical Package for Social Sciences (SPSS) - 18.0. The results show that students recognize the importance of science lessons and its role in daily life, but the proportion of interested in deepening on scientific issues in other information areas is smaller.

Keywords: Attitude. High school. Relevance of science.

1 Doutora em Educação, linha de pesquisa - Ensino de Ciências e Matemática - pela Universidade de São Paulo (USP). Professora Adjunta II do Instituto de Biociências, Departamento de Biologia e Zoologia da Universidade Federal de Mato Grosso (UFMT). Tem experiência na área de Educação, atuando principalmente nos seguintes temas: educação e cultura, ensino de biologia, ensino de evoluçáo biológica, percepção pública e divulgação da ciência. Av. Fernando Corrêa da Costa, no 2367 - Bairro Boa Esperança. Cuiabá - MT - 78060-900. (065)3615-8868. <graciela.ufmt@gmail.com>.

2 Professor titular (MS6) Senior de Metodologia de Ensino de Ciências Biológicas da Faculdade de Educação da Universidade de São Paulo. coordenador científico do Núcleo de Pesquisa em Educação, Divulgação e Epistemologia da Evoluçăo (EDEVO-Darwin), da Pró-Reitoria de Pesquisa da USP. Av. da Universidade, 308 - Cep: 05508-040, Cidade Universitária - São Paulo/SP. E-mail: <bizzo@usp.br>.

R. Educ. Públ.

Cuiabá

v. 28

n. 67

p. $195-217$

jan./abr. 2019 


\section{Introdução}

O objetivo deste trabalho foi verificar as opiniōes dos jovens brasileiros sobre a ciência escolar e o interesse pela ciência fora da escola (hábitos informativos sobre a ciência). Percepçóes dos estudantes sobre a ciência e suas aulas de ciências mostram-se como oportunidades para que educadores e pesquisadores promovam açóes que favoreçam opinióes mais positivas, autônomas e críticas sobre o papel da ciência e dos cientistas na sociedade. Quando se fala em atitudes em relação à ciência refere-se a uma variedade de pensamentos, valores, sentimentos e comportamentos sobre a ciência (VAN AALDEREN-SMEETS; WALMA VAN DER MOLEN; ASMA, 2012).

A atitude e o interesse pela ciência, conforme Logan e Skamp (2008) são construçóes de natureza afetivas e cognitivas que se relacionam a valores, crenças, opiniôes e motivação. Embora as definiçôes do construto de atitude variem muito na literatura, há um consenso de que se trata de uma predisposição a responder positivamente ou negativamente a situaçóes, ideias, pessoas, coisas e lugares. De acordo com Jahoda e Warren (1966), o termo atitude pode ser definido como uma organização duradoura de processos motivacionais, emocionais, perceptivos e cognitivos em relação a algum aspecto do mundo do indivíduo. Dessa forma, esse conceito implica consistência e previsibilidade de respostas constituídas por fundamentos cognitivos, afetivos e comportamentais (KIESLER; COLLINS; MILLER, 1969).

De acordo com Vogt e Castelfranchi (2009), as maneiras que os indivíduos percebem e a utilizam o conhecimento científico articulam-se em razão da compreensão do conteúdo de ciências associada a contextos mais amplos de informações, como: atitudes, opiniōes e valores que são atribuídos à ciência. Dessa forma, construções cognitivas e afetivas interferem no modo como os jovens se relacionam com a ciência e os temas científicos; assim, foram apresentados alguns resultados dessas relaçóes no presente trabalho.

A afetividade possui papel importante no processo de ensino e aprendizagem, e quando os estudantes gostam de ciências na escola, aumentam as chances de continuarem empenhados nesse empreendimento (QUINN; LYONS, 2011). A ciência ensinada na escola, os professores e a ciência fora da escola são fatores que influenciam as opiniōes dos estudantes (CHRISTIDOU, 2011). As crianças e os jovens crescem, aprendem e constroem opinióes sobre ciência em diversos lugares, por exemplo, dentro de suas famílias, com suas comunidades, por meio da mídia, nas ruas, enquanto viajam ou visitam feiras científicas, zoológicos, museus, entre outros (FALLIK; ROSENFELD; EYLON, 2013). 
Quando analisada a relevância da ciência na opinião de jovens, percebe-se que, na maioria das vezes, os estudantes reconhecem que o empreendimento científico é importante para explicar experiências do cotidiano, entretanto, enfatizam principalmente apenas o valor aplicado da ciência (OSBORNE; COLLINS, 2001). Além disso, existe uma aparente contradição entre as atitudes dos estudantes em relação à ciência em geral e em relação à ciência escolar, pois a primeira aparece de modo mais positivo do que a segunda. Enquanto os jovens apontam que a ciência é um empreendimento importante para a sociedade e que a presença da ciência na escola é importante, por outro lado, consideram que as aulas de ciências são chatas (OSBORNE; SIMON; COLLINS, 2003).

De acordo com Christidou (2011), quando os estudantes apresentam atitudes negativas em relação à ciência, isso pode ser parcialmente atribuído à maneira como a ciência é ensinada na escola, pois os currículos de ciências, manuais e livros didáticos, professores e suas práticas de ensino são fatores que interferem no modo como os jovens percebem e lidam com o conhecimento científico. A ciência ensinada não parece relevante e envolvente a ponto de conectar os interesses e as experiências dos jovens com o que está sendo abordado na escola. Esse impasse entre a escola e o cotidiano dos jovens não é restrito à ciência e, de maneira geral, é uma preocupação que direciona as discussóes sobre o ensino e a aprendizagem no ensino básico e as particularidades emocionais, físicas e culturais da adolescência.

Além de fatores pedagógicos, o interesse pela ciência pode ser afetado por influências externas à escola. A percepção dos pais das habilidades das crianças poderia ser uma forte influência na forma como os alunos percebem suas próprias habilidades, o que, por sua vez, poderia influenciar suas expectativas de sucesso, realização, o interesse em disciplinas escolares e carreiras futuras (LOGAN; SKAMP, 2008).

Sobre as influências externas à escola nas opinióes e atitudes dos jovens sobre ciência, Christidou (2011) comenta que os meios de comunicaçâo influenciam diretamente nas concepções, nos interesses e nas atitudes em relação à ciência. Essas fontes de informação muitas vezes promovem imagens desatualizadas, controversas, estereotipadas da ciência e dos cientistas.

Fatores inerentes às características dos estudantes e fatores ambientais influenciam nas atitudes, nos valores e nas opinióes sobre ciência e, consequentemente, esses sentimentos estão relacionados às formas que os jovens se relacionam com os diferentes temas científicos apresentados na escola. No entanto, apenas dando voz aos estudantes será possível conhecer o que os jovens pensam, sentem e fazem quando se trata de ciência e, principalmente, quais os fatores que interferem nessas relaçóes e construçóes de valores. Ouvir o que o estudante de hoje tem a dizer possibilita entender a relaçáo da sociedade com a 
ciência, no presente e no futuro, pois esse segmento reflete os grupos, as imagens e as ideias disseminadas na população atual, assim como as atitudes e as opinióes apreendidas hoje devem influenciar as ações dos adultos de amanhã.

\section{Método}

Houve a participação de 2.404 estudantes $(55,1 \%$ meninas $)$ matriculados no $1^{\circ}$ ano do Ensino Médio de 78 escolas (públicas e privadas) das cinco regióes brasileiras. Quanto à faixa etária dos jovens que participaram da pesquisa, houve maior frequência de estudantes com 15 anos de idade (47,4\%).

Para determinaçáo do tamanho de amostra, de representatividade nacional, considerou-se como objetivo do estudo verificar a proporção de alunos que se interessam por ciência e temas científicos. Inferiu-se que seriam encontradas as proporçóes de $80 \%$ de estudantes interessados e $20 \%$ de estudantes desinteressados por temas científicos. Essas proporçóes foram consideradas em razão de resultados encontrados em estudos anteriores realizados por Santos-Gouw (2013) e Mota (2013).

O tamanho mínimo da amostra foi determinado utilizando-se a expressão algébrica referente ao cálculo do tamanho da amostra para estimaçáo de proporçóes: $n=\frac{P \cdot(1-P)}{(d / z)^{2}}$ deff, em que $P$ é a proporçáo de alunos a ser estimada (P $=0,80$ ou $\mathrm{P}=0,20) ; z=1,96$ é o valor na curva normal reduzida, correspondente ao nível de confiança de $95 \%$, utilizado na determinaçáo do intervalo de confiança das proporçóes; $d$ é o erro de amostragem admitido, fixado em 0,05, e que corresponde à semiamplitude dos intervalos de confiança; e deff $=2$ é o efeito do delineamento devido ao sorteio de conglomerados (escolas). Dessa forma, 500 era o número esperado de alunos a ser incluído na amostra em cada regiáo. Para o sorteio aleatório da amostra, foi utilizado o processo de amostragem estratificada por conglomerados em dois estágios: escola e turma.

Incialmente, foram sorteadas 15 escolas em cada regiáo, e em cada escola deveria ser sorteada uma turma do $1^{\circ}$ ano do Ensino Médio. Esperava-se, dessa forma, que fossem incluídas na amostra 75 escolas no país e, em média, 35 alunos por escola, mas os questionários foram respondidos por uma média de 25 a 30 alunos por escola. Para prevenir os efeitos da não resposta na precisão das estimativas, foi sorteado um número maior de escolas e de alunos. Considerandose que a náo resposta (de escolas e de alunos) fosse da ordem de $25 \%$, foram sorteadas 20 escolas em cada região, 100 no total. A composição da amostra final por regiáo foi: 573 estudantes do Centro-Oeste (23,8\%); 505 do Nordeste (21\%); 480 do Norte (20\%); 413 do Sudeste (17,2\%); e 433 do Sul (18\%). 
O questionário Barômetro foi elaborado e validado a partir da redução de itens do questionário ROSE (Relevance of Science Education) (SANTOS-GOUW, 2013; MOTA, 2013). Foram mantidas a estrutura e a ordenação das questōes, bem como os objetivos (verificar as percepções, motivaçóes, interesses e opinióes dos jovens sobre a ciência, tecnologia, questóes ambientais e temas científicos). Os itens foram constituídos usando escalas do tipo Likert de 4 pontos.

Os 245 itens disponíveis no questionário ROSE foram testados quanto à correlação entre os construtos, seguido do estudo da diversidade de respostas por sexo, garantindo a redução para 73 itens, mas sem perder os agrupamentos de construtos necessários para explicar as dimensóes que medem a relação dos respondentes com a ciência, tecnologia, interesse por temas científicos, entre outros.

Neste trabalho, serão apresentadas as seçôes do questionário, estruturadas em escalas do tipo Likert de 4 pontos, referentes aos hábitos informativos sobre temas científicos, isso é, a frequência com que os jovens buscam por informaçóes científicas em ambientes virtuais, revistas, livros, televisão, museus, centros científicos, entre outros. Na sequência, foram analisados os itens da seção " $A s$ minhas aulas de ciências", e verificaram-se as opiniōes dos estudantes sobre as aulas de ciências.

Após a seleção da população-alvo, construção e validação do instrumento de coleta de dados, iniciou-se o desenvolvimento da logística para aplicação dos questionários e adotaram-se os seguintes critérios: 1) composição de uma equipe de pesquisa responsável pela coleta de dados; 2) contatos com as escolas e solicitaçáo de professores colaboradores; 3 ) envio de orientaçóes e questionários impressos por correio; 4) aplicação e devolução dos questionários, pelos professores colaboradores, sob a orientação da equipe de pesquisa.

Os contatos com as 100 escolas sorteadas aconteceram entre os meses de março a maio de 2014; contudo, nos contatos iniciais, algumas se recusaram a participar e, por isso, utilizou-se uma lista reserva de escolas sorteadas $(\mathrm{N}=20)$ a fim de garantir o envio dos questionários a 100 escolas, como estipulado no plano amostral.

Após a confirmação de interesse em participar da pesquisa, foram postados via correio os questionários para preenchimento. A aplicação do instrumento foi realizada entre os meses de maio a julho de $2014 \mathrm{em}$ uma turma de $1^{\circ}$ ano do Ensino Médio sorteada pelo professor colaborador da escola. As aplicaçóes aconteceram em dias letivos e em sala de aula, e duravam em média 30 minutos.

Em seguida, os dados foram codificados, organizados e processados com auxílio do Software Statistical Package for Social Science (SPSS) - Pacote Estatístico para as Ciências Sociais - versão 18.0. Para a análise dos dados foi feita a descrição e as pontuaçóes obtidas para cada variável, verificando o conjunto de frequências 
encontradas em cada categoria do questionário. Neste artigo, as distribuiçóes foram organizadas e representadas principalmente pelas frequências relativas e médias/desvio-padrão. Para verificar as diferenças entre as distribuiçóes de frequências atingidas nas questôes analisadas, foram utilizados os testes: Quiquadrado, Mann-Whitney e Kruskal-Wallis, seguidos das comparaçóes múltiplas entre grupos mediante teste de Tukey.

\section{Hábito informativo: pesquisas científicas e visitas em espaços científicos}

De acordo com Vogt, Morales e Caldas (2011), em estudos de percepção pública, o consumo de informação científica e tecnológica é uma dimensão central de análise, que atua juntamente com as dimensóes de interesse, conhecimento em ciência e tecnologia. $\mathrm{O}$ índice de consumo informativo ou hábito informativo (frequência com que os jovens buscam informaçóes sobre temas de ciência) baseiase apenas no que as pessoas declaram sobre os seus hábitos de busca e acesso à informação; no entanto, é necessário considerar que pode haver divergência entre o que é declarado e o comportamento (VOGT; MORALES; CALDAS, 2011).

Para compreender a aprendizagem de ciência por crianças e jovens, não se deve olhar apenas para a educação formal, mas também para a aprendizagem que acontece fora da escola (ESHACH, 2007). O envolvimento dos estudantes com a ciência ensinada em espaços não formais e informais pode contribuir com maior compromisso e percepçóes mais positivas em relação à ciência. As atividades em ambientes não formais, como visitas a museus, centros e feiras de ciências, promovem habilidades de raciocínio científico e contribuem para a formação de adultos cientificamente informados (SIMPSON; PARSONS, 2009).

A experiência de vida das crianças dentro e fora da escola tem efeitos profundos sobre suas percepções de temas científicos. Eshach (2007) sugere que museus ou centros de ciências possuem o potencial de envolver os estudantes e estimular a sua compreensão, bem como ajudá-los a assumir a responsabilidade pela sua própria aprendizagem.

Quando se fala em ter acesso a conhecimentos científicos fora da escola, é necessário reconhecer três tipos de espaços de ensino-aprendizagem: formal, informal e não formal. Segundo Eshach (2007), as educações formal e não formal acontecem em espaços institucionais, organizadas a partir de objetivos específicos e mediadas por ações intencionais. Todavia, a educação não formal possui caráter de alta adaptação a diferentes públicos e regras menos restritivas que a educação formal, que determina, por exemplo, a sequência de conteúdos 
conforme idade e série. A organização da educação não formal é mais flexível, mas a motivaçáo para aprendizagem é mais intrínseca e voluntária ao aprendiz, existe maior liberdade de escolha $\mathrm{e}$, geralmente, os conhecimentos não são avaliados e não são sequenciais.

A educação informal, por outro lado, não segue regras sistematizadas e estruturadas e aplica-se a situaçóes da vida que surgem espontaneamente; por exemplo, no interior do círculo familiar, da comunidade, sendo os conhecimentos adquiridos no meio social. A aprendizagem informal se distingue das outras duas por não ter nenhuma figura de autoridade ou mediador e surge a partir das relaçóes sociais (ESHACH, 2007). Dentre os espaços socializadores, além da família e comunidade, também se destaca a mídia como importante veículo de informação e aprendizagem.

Nesse sentido, ao considerar a busca de informaçóes científicas fora da escola, na presente pesquisa, foram previstos espaços institucionais, como centros científicos, zoológicos, museus, entre outros, e veículos midiáticos, como internet, televisão e cinema. Simpson e Parsons (2009) comentam que experiências de educação fora da escola incluem visitas a museus, centros de ciência, jardins zoológicos, parques, centros de natureza, acesso a à televisão, internet, cinema, participação em organizaçóes e projetos de base comunitária, entre outros. Substancialmente, o que caracteriza esses espaços é o seu caráter de livre escolha, não sequencial, de ritmo individual e voluntário.

Simpson e Parsons (2009) ainda destacam que, embora seja reconhecido o potencial desses espaços para favorecer a aproximação dos jovens à ciência, mensagens distorcidas ou estereótipos podem ser vinculados e divulgados por esses veículos de informação. Nesse sentido, destacam-se principalmente a televisão e a internet, mas até mesmo museus e centros de ciência não estão isentos da possibilidade de afastar os jovens da ciência ou contribuir com a construção de imagens distorcidas. Dessa forma, comunicação e instrução estão vinculadas a esses espaços, e as várias mensagens positivas ou não, distorcidas e estereotipadas ou não, influenciam as relaçóes dos jovens com a ciência.

Quando verificados os espaços e as experiências que têm atuado em conjunto com a escola na construção de valores em relação à ciência para os jovens brasileiros, observa-se que houve diferença estatística ao nível de 5\% nas respostas por sexo. Os estudantes parecem pouco habituados a visitar e frequentar espaços científicos, como centros e museus científicos (média de meninas: $1,95 \pm 1,03$; meninos: $1,94 \pm 1,03$ ), feiras ou olímpiadas científicas (média de meninas: $1,99 \pm 1,13$; meninos: 1,87 $\pm 1,07$ ). E, embora as visitas a zoológicos e jardins botânicos pareçam mais frequentes, a média atingida por meninos e meninas náo ultrapassou 2,25 pontos. 
Quanto às afirmaçóes sobre o uso de redes sociais para pesquisa sobre temas científicos e a troca de informaçóes com professores pela internet, as médias também foram mais baixas. As afirmaçôes que apresentaram médias mais altas tratavam sobre o hábito informativo a partir de programas e documentários sobre temas científicos na televisão ou no cinema (média de meninas: 3,10 $\pm 1,00$; meninos: 3,11 $\pm 0,99$ ). Em seguida, os itens mais assinalados foram $L i$ coisas sobre a natureza ou as ciências em livros ou revistas (média de meninas: 3,03 $\pm 1,02$; meninos: 2,86 $\pm 1,04)$; Procurei informaçóes sobre ciência e tecnologia na internet (média de meninas: $2,52 \pm 1,11$; meninos: $2,59 \pm 1,15$ ). O hábito de leitura sobre temas científicos em revistas e livros foi mais frequente entre as meninas.

$\mathrm{O}$ acesso a experiências científicas informais pode oferecer uma oportunidade de aprender a ciência em um ambiente onde as expectativas culturais são menos rígidas do que as salas de aulas formais. Os aspectos de livre escolha e por não serem atividades avaliativas parecem atuar positivamente na promoção da aprendizagem, de modo que as experiências informais com a ciência representam espaços em que o estudante se sente mais à vontade para fazer suas próprias escolhas (SIMPSON; PARSONS, 2009).

Apesar disso, identificou-se uma baixa frequência entre os jovens brasileiros pela busca de informaçóes científicas em espaços informais e não formal; tendo em vista que a pontuação máxima para cada item era de 4 pontos, os itens mais frequentes foram o acesso a informaçóes por meio de livros e televisão. Esses resultados podem indicar que, no país, ainda há pouco investimento na área científica e, consequentemente, carência de espaços e centros de ciências disponíveis para visitação do público em geral. Ainda sugerem que as regióes que possuem esses espaços não têm encontrado maneiras efetivas de atrair os jovens para os seus programas e exposiçóes.

Embora a internet seja um veículo em que a população em geral possui maior acesso, as médias para o seu uso na busca de informaçóes científicas também foram mais baixas, principalmente o uso de redes sociais e a troca de informaçóes por meio da internet com os professores.

Ao verificar os percentuais do item Vi documentários sobre a natureza na televisão ou no cinema, entre as meninas, $9,1 \%$ assinalaram a opção Nunca e 47,1 assinalaram a opção Muitas vezes; e entre os meninos, 8,2\% assinalaram Nunca e 48,1\% assinalaram Muitas vezes. Esses dados assemelham-se com os resultados encontrados por Vogt, Morales e Caldas (2011), que apontaram a televisão como a principal fonte de informação sobre ciência e tecnologia. $\mathrm{O}$ hábito de assistir a programas e documentários na televisão sobre natureza e vida animal foi o item mais assinalado entre os jovens e teve média de 2,3. Para esses resultados, os autores consideraram a média alta, pois, de maneira geral, os jovens pareceram pouco habituados a frequentar espaços científicos ou se informar sobre o tema. 
Ainda de acordo com Vogt, Morales e Caldas (2011), o meio de comunicação mais comum entre os jovens é a televisão, o que parece justificado pelo fácil acesso ao veículo, já que a maioria dos lares hoje em dia tem pelo menos uma TV e revela-se como a principal fonte de informação para população.

As médias obtidas pelos estudantes sobre visitas e busca por conhecimento científico também foram analisadas à luz das regióes brasileiras (Tabela 1).

Tabela 1: Médias (desvio-padrão) e teste de Kruskal-Wallis quanto à pesquisa e a visitas a espaços científicos, por região

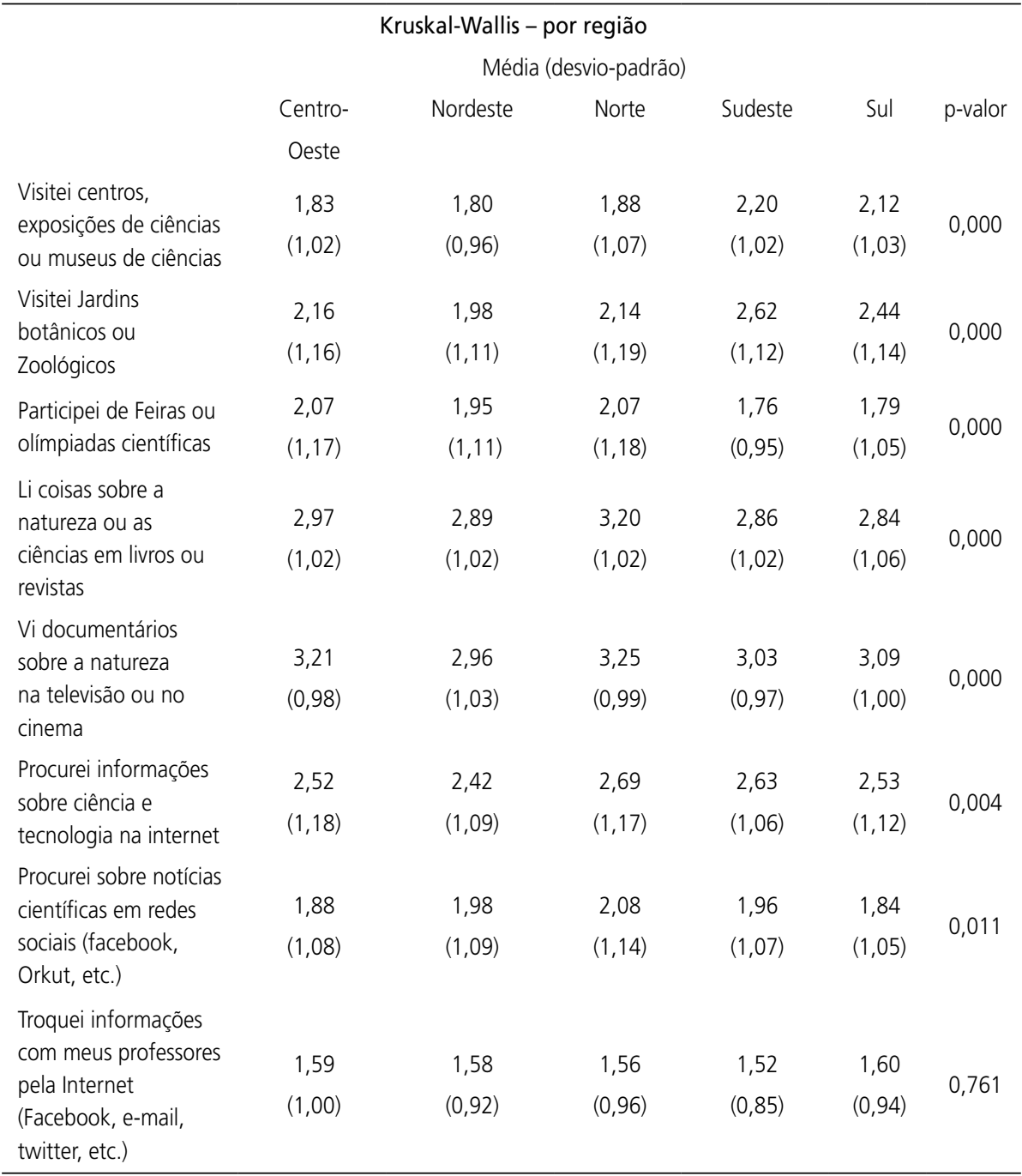

Fonte: Elaboração própria (2015).

R. Educ. Públ. Cuiabá, v. 28, n. 67, p. 195-217, jan./abr. 2019 
Houve diferença significativa nas respostas dos estudantes por subgrupos regionais. Nas variáveis sobre a busca de notícias científicas e troca de informaçóes com os professores por meio de redes sociais não houve diferença nas respostas dos estudantes das cinco regióes e, de maneira geral, as médias atingidas foram baixas. Os veículos de informação atuam de diferentes maneiras, conforme a região do país. Os resultados apontam que a visita a centros científicos, museus, jardins botânicos e zoológicos é mais frequente entre os jovens do Sudeste e Sul; já a participação em feiras ou olímpiadas científicas aparece mais alta entre os estudantes do Centro-Oeste e Norte. Essas regióes também se destacaram quanto aos hábitos de ler livros e revistas especializadas e de assistir a documentários sobre a natureza. $\mathrm{O}$ uso da internet para pesquisa sobre temas científicos foi menor entre os estudantes do Norte, já a busca de informaçóes científicas por meio das redes sociais foi menor para os estudantes do Sul.

Esses resultados servem como indicadores de que o acesso a alguns veículos de informação científica difere conforme a região do país. A maior frequência dos estudantes do Sul e Sudeste a espaços de divulgação científica sugere que algumas regiōes carecem de museus e centros científicos, pois, embora haja museus históricos pelo país, os científicos ainda são incipientes, assim como zoológicos e jardins botânicos. De acordo com Massarani e Moreira (2009), apenas 4\% da população brasileira visita museus e centros científicos, espaços que são ainda relativamente poucos e com desigualdades regionais em sua distribuição. Além disso, os autores destacam que "classes socioeconômicas mais altas (A e B) têm percentual até $200 \%$ maior nesta frequência que o das classes sociais mais baixas (C, D e E).” (MASSARANI; MOREIRA, 2009, p. 110).

Nesse sentido, buscou-se verificar a distribuição das respostas dos estudantes sobre os espaços de acesso à informação científica a partir de variáveis socioeconômicas. Couri (2010, p. 454) comenta que não há uma única maneira de calcular indicadores socioeconômicos de um grupo de sujeitos, mas é possível considerar três dimensóes ao elaborar e analisar variáveis socioeconômicas: "a dos recursos econômicos - ou capital econômico da família; a dimensão dos recursos educacionais, também denominados capital humano ou capital cultural; e, por fim, a dimensão das relaçóes familiares, ou capital social familiar." Os itens desse questionário foram testados a partir das variáveis, de condiçóes de moradia representados pelo número de banheiros e dimensóes de capital cultural a partir do número de livros e escolaridade dos pais.

Tanto as dimensões de condiçóes de moradia como as de recursos educacionais revelam que há diferença nas respostas dos jovens, de acordo com o nível social, uma vez que a partir de recursos econômicos aumenta-se o acesso ao capital cultural. Assim, os itens que apresentaram diferenças significativas nas quatro 
categorias (número de banheiros e de livros, instrução da mãe e do pai) foram: visitas aos museus, centros científicos, zoológicos e jardins botânicos. Por outro lado, os itens que não apresentaram diferenças nas respostas dos jovens foram os que tratavam do acesso à informaçáo científica por meio de livros e televisão, possivelmente pelo fácil acesso a esses veículos de informação (Tabela 2).

Tabela 2: Teste de Kruskal-Wallis quanto à pesquisa e a visitas a espaços científicos, por aspectos socioeconômicos

\begin{tabular}{|c|c|c|c|c|}
\hline \multicolumn{5}{|c|}{ Teste Kruskal-Wallis ( $p$-valor) } \\
\hline & $\begin{array}{l}\text { Número de } \\
\text { Banheiros }\end{array}$ & $\begin{array}{l}\text { Número de } \\
\text { Livros }\end{array}$ & $\begin{array}{l}\text { Instrução da } \\
\text { Mãe }\end{array}$ & $\begin{array}{l}\text { Instrução do } \\
\text { Pai }\end{array}$ \\
\hline $\begin{array}{l}\text { Visitei centros, exposições de } \\
\text { ciências ou museus de ciências }\end{array}$ & 0,000 & 0,000 & 0,000 & 0,000 \\
\hline $\begin{array}{l}\text { Visitei Jardins botânicos ou } \\
\text { Zoológicos }\end{array}$ & 0,000 & 0,000 & 0,000 & 0,000 \\
\hline $\begin{array}{l}\text { Participei de Feiras ou } \\
\text { olímpiadas científicas }\end{array}$ & 0,472 & 0,094 & 0,037 & 0,116 \\
\hline $\begin{array}{l}\text { Li coisas sobre a natureza ou as } \\
\text { ciências em livros ou revistas }\end{array}$ & 0,033 & 0,000 & 0,016 & 0,031 \\
\hline $\begin{array}{l}\text { Vi documentários sobre a } \\
\text { natureza na televisão ou no } \\
\text { cinema }\end{array}$ & 0,593 & 0,000 & 0,150 & 0,357 \\
\hline $\begin{array}{l}\text { Procurei informações sobre } \\
\text { ciência e tecnologia na internet }\end{array}$ & 0,153 & 0,000 & 0,000 & 0,000 \\
\hline $\begin{array}{l}\text { Procurei sobre notícias } \\
\text { científicas em redes sociais } \\
\text { (facebook, Orkut, etc.) }\end{array}$ & 0,188 & 0,000 & 0,001 & 0,000 \\
\hline $\begin{array}{l}\text { Troquei informações com } \\
\text { meus professores pela Internet } \\
\text { (Facebook, e-mail, twitter, etc.) }\end{array}$ & 0,070 & 0,008 & 0,000 & 0,000 \\
\hline
\end{tabular}

Fonte: Elaboração própria (2015).

A distribuição das respostas dos estudantes a partir da variável número de livros pode ser exemplificada pelo item Visitei jardins botânicos ou zoológicos: Nenhum - 2,17 $\pm 1,21$; 1-10 livros - 2,22 $\pm 3,45$; $11-50$ livros - 2,31 $\pm 1,17$; 51 100 livros $-2,39 \pm 1,17 ; 101-250$ livros $-2,56 \pm 1,18$; $251-500$ livros $-2,44 \pm 1,11$; Mais de 500 livros - 2,34 $\pm 1,17$. 
$\mathrm{Na}$ variável escolaridade dos pais, houve a mesma tendência: a frequência e o acesso à informaçáo aumentaram conforme a melhora do nível socioeconômico. Os estudantes que declararam que os pais não são escolarizados e os que possuem apenas Ensino Fundamental apresentaram médias mais baixas do que os estudantes cujos pais possuem Ensino Médio e Superior, para os itens relativos à visita a museus, centros científicos, jardins botânicos e zoológicos. Da mesma forma, nos itens que sugerem a frequência do uso da internet para pesquisa e troca de informaçóes por meio de redes sociais, os jovens cujos pais têm Ensino Superior atingiram as médias mais altas do que os demais grupos (Tabela 3).

De maneira geral, os resultados apontam que na variável número de banheiro, os jovens que assinalaram as opçóes Nenhum a 2 banheiros apresentaram médias mais baixas do que os jovens com 3 a Mais de 5 banheiros em casa. A mesma tendência de respostas foi encontrada para o número de livros, pois, entre as variáveis Nenhum a 1-10 livros, as médias foram mais baixas do que as encontradas para a amostra que possui a partir de 11-50 livros a Mais de 500 livros. Percebe-se que as médias aumentam conforme o nível socioeconômico. As tendências de respostas por níveis socioeconômicos seguem a mesma variação, e a média aumenta conforme melhoram as condiçóes econômicas. $\mathrm{O}$ item Visitei centros, exposiçóes de ciências ou museus de ciências exemplifica as médias identificadas; na variável número de banheiro, observou-

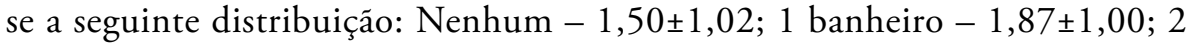
banheiros $-1,99 \pm 1,05 ; 3$ banheiros $-2,20 \pm 1,05$; 4 banheiros $-2,40 \pm 1,05 ; 5$ banheiros $-2,41 \pm 1,15$; Mais de 5 banheiros $-2,15 \pm 1,14$. 
Tabela 3: Média (desvio-padrão) quanto à pesquisa e a visitas a espaços científicos, por escolaridade dos pais

\begin{tabular}{|c|c|c|c|}
\hline & & \multicolumn{2}{|c|}{ Média (desvio-padrão) } \\
\hline & & $\begin{array}{l}\text { Instrução da } \\
\text { Mãe }\end{array}$ & $\begin{array}{c}\text { Instrução do } \\
\text { Pai }\end{array}$ \\
\hline \multirow{4}{*}{$\begin{array}{l}\text { Visitei centros, exposições de } \\
\text { ciências ou museus de ciências }\end{array}$} & Não escolarizado & $1,55(0,99)$ & $1,57(0,97)$ \\
\hline & Ensino Fundamental & $1,80(1,00)$ & $1,85(1,01)$ \\
\hline & Ensino Médio & $2,03(1,03)$ & $2,03(1,03)$ \\
\hline & Ensino Superior & $2,11(1,00)$ & $2,20(1,04)$ \\
\hline \multirow{4}{*}{$\begin{array}{l}\text { Visitei Jardins botânicos ou } \\
\text { Zoológicos }\end{array}$} & Não escolarizado & $1,84(1,17)$ & $1,81(1,10)$ \\
\hline & Ensino Fundamental & $2,04(1,15)$ & $2,17(3,32)$ \\
\hline & Ensino Médio & $2,47(3,40)$ & $2,40(1,17)$ \\
\hline & Ensino Superior & $2,46(1,11)$ & $2,57(1,08)$ \\
\hline \multirow{4}{*}{$\begin{array}{l}\text { Procurei informações sobre } \\
\text { ciência e tecnologia na internet }\end{array}$} & Não escolarizado & $2,17(1,28)$ & $2,34(1,23)$ \\
\hline & Ensino Fundamental & $2,47(1,14)$ & $2,45(1,12)$ \\
\hline & Ensino Médio & $2,55(1,11)$ & $2,59(1,13)$ \\
\hline & Ensino Superior & $2,97(4,54)$ & $3,07(5,09)$ \\
\hline \multirow{4}{*}{$\begin{array}{l}\text { Procurei sobre notícias científicas } \\
\text { em redes sociais (facebook, } \\
\text { Orkut, etc.) }\end{array}$} & Não escolarizado & $2,04(1,27)$ & $1,89(1,13)$ \\
\hline & Ensino Fundamental & $1,89(1,08)$ & $1,87(1,05)$ \\
\hline & Ensino Médio & $1,93(1,07)$ & $2,07(3,56)$ \\
\hline & Ensino Superior & $2,29(4,56)$ & $2,20(1,10)$ \\
\hline \multirow{4}{*}{$\begin{array}{l}\text { Troquei informações com } \\
\text { meus professores pela Internet } \\
\text { (Facebook, e-mail, twitter, etc.) }\end{array}$} & Não escolarizado & $1,35(0,78)$ & $1,39(0,79)$ \\
\hline & Ensino Fundamental & $1,51(0,92)$ & $1,50(0,90)$ \\
\hline & Ensino Médio & $1,60(0,97)$ & $1,62(0,96)$ \\
\hline & Ensino Superior & $1,64(0,91)$ & $1,69(0,98)$ \\
\hline
\end{tabular}

Fonte: Elaboração própria (2015). 
Os resultados encontrados nas respostas dos jovens a partir das dimensões de condiçóes de moradia e capital cultural concordam com os dados apresentados por Massarani e Moreira (2009), pois se observa que desigualdades socioeconômicas parecem atreladas à busca e ao acesso a espaços científicos. De acordo com Couri (2010), o capital cultural é o fator que possui maior impacto no desempenho dos alunos. Na presente investigaçáo, confirma que também influencia o hábito informativo acerca da ciência.

\section{As opiniões dos jovens brasileiros sobre as aulas de ciências}

As percepçóes de estudantes sobre as aulas de ciências contribuem na identificação, por um lado, dos valores construídos sobre ciência e, por outro, das variáveis associadas ao interesse pela ciência ao longo da escolarização. Há vários fatores que parecem inter-relacionados com as atitudes dos jovens em relaçáo à ciência, e, embora não seja o único espaço de construção de valores, a escola, por meio das experiências com as ciências nas aulas, apresenta papel importante, pois é um espaço formal e específico de ensino e aprendizagem sobre a ciência e como se faz a ciência.

Jidesjö et al. (2009) aplicaram e analisaram dados coletados por meio do instrumento ROSE, em 2003, a uma amostra de 751 estudantes (358 meninas e 392 meninos, 1 não respondeu), com a faixa etária de 15 anos, matriculados em 29 escolas suecas. Acerca das aulas de ciências, os estudantes acreditam que todos devem estudar ciências na escola $(2,81 \pm 1,12)$ e que se trata de um empreendimento útil na vida cotidiana $(2,69 \pm 1,02)$. Por outro lado, discordam da afirmação de que deveria haver mais aulas de ciências na escola $(1,75 \pm 0,96)$. Além disso, os estudantes não gostariam de ser cientistas $(1,68 \pm 1,00)$ ou seguir uma carreira que lide com tecnologia $(2,12 \pm 1,18)$.

Não foram encontradas diferenças significativas nas respostas de meninos e meninas, exceto nos itens sobre o interesse em seguir uma carreira científica, em que os meninos apresentaram uma posição mais positiva. Além disso, as meninas consideram a disciplina ciências mais difícil do que os meninos (JIDESJÖ et al., 2009).

De maneira geral, os jovens consideraram que a ciência apresentada na escola é importante, mas menos interessante do que as demais disciplinas, e não apresentam interesse em seguir uma carreira científica. Para os estudantes suecos, confirma-se a tendência encontrada em trabalhos anteriores, nos quais os jovens consideram que "a ciência é importante, mas não para mim". Os estudantes parecem não compreender que ciência se relaciona com suas experiências 
cotidianas, o que tem implicaçóes potenciais para a sua futura participação como cidadãos cientificamente informados (JIDESJÖ et al., 2009).

O ensino de ciências descontextualizado, na maioria das vezes, impossibilita o desenvolvimento do pensamento e da ação sobre questóes científicas que possam afetar as vidas dos jovens e as vidas dos outros membros das comunidades locais e globais de que eles fazem parte (BENNETT; LUBBEN; HOGRATH, 2006).

Lyons (2006) comparou experiências dos estudantes da Suécia, Inglaterra e Austrália com as aulas de ciências e encontrou algumas características em comum: conteúdo descontextualizado, pedagogia transmissiva e dificuldades desnecessárias.

Danaia, Fitzgerald e Mckinnon (2013) desenvolveram uma pesquisa sobre a relaçáo de jovens australianos com a ciência ensinada na escola, a partir da aplicação de questionários, em 2011, para 1.585 estudantes do Ensino Médio e para 2.016, em 2005, matriculados em 49 escolas. Os dados foram comparados com uma terceira amostra coletada em 2001 e divulgada por Goodrum et al. (2001). Nas três amostras, os autores constataram que a maioria dos jovens considera que a ciência ensinada na escola é raramente útil na vida cotidiana e náo parece relevante para o seu futuro. Além disso, os jovens apontaram que a ciência escolar não contribui para tomar decisóes sobre a sua saúde e compreender as questóes ambientais, e que raramente a disciplina ciências apresenta questóes que realmente os preocupa.

Os trabalhos desenvolvidos por Jidesjö et al. (2009) e Danaia, Fitzgerald e Mckinnon (2013) apontam para o baixo interesse dos jovens pelas aulas de ciências, principalmente pela falta de conexão entre o que é ensinado em sala de aula e o cotidiano. Entretanto, os dados brasileiros apresentados por Santos-Gouw (2013) apontam para uma tendência oposta, pois os estudantes possuem maior interesse pelas aulas de ciências e consideram que o que é ensinado trata de questôes importantes para o cotidiano.

Os resultados encontrados no presente estudo seguem a tendência apresentada por Santos-Gouw (2013), pois os estudantes apontam para atitudes positivas em relação às aulas de ciências. Houve diferença significativa nas respostas dos jovens quanto ao sexo, mas, de modo geral, ambos apresentaram médias altas para as afirmaçóes disponíveis no questionário (Tabela 4). 
Tabela 4: Média (desvio-padrão) e teste de Mann Whitey com relação ao interesse pelas aulas de ciências, por sexo

\begin{tabular}{|c|c|c|c|c|}
\hline \multicolumn{5}{|c|}{ Teste Mann-Whitney - Sexo } \\
\hline & \multicolumn{2}{|c|}{ Média (desvio-padrão) } & \multirow[b]{2}{*}{$\begin{array}{l}\text { Diferença } \\
\text { F-M }\end{array}$} & \multirow[b]{2}{*}{$\mathrm{p}$-valor } \\
\hline & $\mathrm{F}$ & M & & \\
\hline Penso que todos deverão aprender Ciências & $3,21(0,99)$ & $3,01(1,07)$ & 0,21 & 0,000 \\
\hline $\begin{array}{l}\text { Os conhecimentos que adquiro nas aulas de } \\
\text { Ciências serão úteis na minha vida cotidiana }\end{array}$ & $3,37(0,86)$ & $3,20(0,95)$ & 0,18 & 0,000 \\
\hline $\begin{array}{l}\text { Penso que a ciência que eu aprendo na } \\
\text { escola melhorará as minhas oportunidades } \\
\text { de carreira }\end{array}$ & $3,04(0,99)$ & $2,94(1,02)$ & 0,09 & 0,027 \\
\hline $\begin{array}{l}\text { As aulas de Ciências estimulam a minha } \\
\text { curiosidade acerca das coisas que ainda não } \\
\text { conseguimos explicar }\end{array}$ & $3,33(0,93)$ & $3,16(1,01)$ & 0,16 & 0,000 \\
\hline $\begin{array}{l}\text { As aulas de Ciências aumentam o meu } \\
\text { gosto pela natureza }\end{array}$ & $3,05(0,98)$ & $2,89(1,05)$ & 0,16 & 0,000 \\
\hline $\begin{array}{l}\text { Eu gostaria de ter mais aulas de Ciências } \\
\text { na escola }\end{array}$ & $2,64(1,12)$ & $2,49(1,16)$ & 0,15 & 0,002 \\
\hline $\begin{array}{l}\text { A ciência que aprendo na escola me ensina } \\
\text { a cuidar melhor da minha saúde }\end{array}$ & $3,17(0,96)$ & $3,09(0,98)$ & 0,07 & 0,460 \\
\hline
\end{tabular}

Fonte: Elaboração própria (2015)

Considerando que a média mais alta para essa questão deveria se aproximar de 4 pontos, a maioria dos jovens concorda com os construtos sobre as aulas de ciências. As meninas são mais motivadas do que os meninos, pois concordam que todos deveriam aprender ciências $(3,21 \pm 0,99)$ e que os conhecimentos científicos adquiridos nas aulas são úteis e substanciais para o estímulo à curiosidade $(3,33 \pm 0,93)$, o gosto pela natureza $(3,05 \pm 0,98)$, e amplia a possibilidades de carreira. Além disso, os estudantes, tanto as meninas como os meninos, consideraram que a ciência apresentada na escola ajuda a melhorar a saúde.

$\mathrm{O}$ item com menor concordância foi "Eu gostaria de ter mais aulas de Ciências na escola", sobre o qual as meninas demonstraram menor interesse do que os meninos. Embora os jovens reconheçam a importância das aulas, bem como percebam a conexão entre o que é estudado com o cotidiano, as questôes ambientais e a saúde, e com as oportunidades de carreira, não há a mesma motivação quanto ao aumento das aulas ciências na escola. 
A variedade e as diferenças nas respostas quanto às aulas de ciências, por região, são apresentadas nas Tabelas 5 e 6.

Tabela 5: Média (desvio-padrão) e teste de Kruskall Wallis com relação ao interesse pelas aulas de ciências, por região

\begin{tabular}{|c|c|c|c|c|c|c|}
\hline \multicolumn{7}{|c|}{ Kruskal-Wallis - por região } \\
\hline & \multicolumn{5}{|c|}{ Média (desvio-padrão) } & \multirow[b]{2}{*}{ p-valor } \\
\hline & $\begin{array}{l}\text { Centro- } \\
\text { Oeste }\end{array}$ & Nordeste & Norte & Sudeste & Sul & \\
\hline $\begin{array}{l}\text { Penso que todos deverão } \\
\text { aprender Ciências }\end{array}$ & $\begin{array}{l}3,00 \\
(1,11)\end{array}$ & $\begin{array}{l}3,19 \\
(0,97)\end{array}$ & $\begin{array}{l}3,29 \\
(0,97)\end{array}$ & $\begin{array}{l}3,10 \\
(1,03)\end{array}$ & $\begin{array}{c}3,03 \\
(1,04)\end{array}$ & 0,000 \\
\hline $\begin{array}{l}\text { Os conhecimentos que } \\
\text { adquiro nas aulas de } \\
\text { Ciências serão úteis na } \\
\text { minha vida cotidiana }\end{array}$ & $\begin{array}{l}3,31 \\
(0,92)\end{array}$ & $\begin{array}{l}3,45 \\
(0,81)\end{array}$ & $\begin{array}{l}3,42 \\
(0,88)\end{array}$ & $\begin{array}{l}3,11 \\
(0,94)\end{array}$ & $\begin{array}{c}3,14 \\
(0,93)\end{array}$ & 0,000 \\
\hline $\begin{array}{l}\text { Penso que a ciência que } \\
\text { eu aprendo na escola } \\
\text { melhorará as minhas } \\
\text { oportunidades de } \\
\text { carreira }\end{array}$ & $\begin{array}{l}3,00 \\
(1,02)\end{array}$ & $\begin{array}{l}3,11 \\
(0,95)\end{array}$ & $\begin{array}{l}3,17 \\
(0,96)\end{array}$ & $\begin{array}{l}2,76 \\
(1,06)\end{array}$ & $\begin{array}{c}2,88 \\
(0,98)\end{array}$ & 0,000 \\
\hline $\begin{array}{l}\text { As aulas de Ciências } \\
\text { estimulam a minha } \\
\text { curiosidade acerca das } \\
\text { coisas que ainda não } \\
\text { conseguimos explicar }\end{array}$ & $\begin{array}{l}3,20 \\
(1,02)\end{array}$ & $\begin{array}{l}3,26 \\
(0,91)\end{array}$ & $\begin{array}{l}3,35 \\
(0,91)\end{array}$ & $\begin{array}{c}3,18 \\
(1,04)\end{array}$ & $\begin{array}{c}3,28 \\
(0,95)\end{array}$ & 0,129 \\
\hline $\begin{array}{l}\text { As aulas de Ciências } \\
\text { aumentam o meu gosto } \\
\text { pela natureza }\end{array}$ & $\begin{array}{l}2,94 \\
(1,05)\end{array}$ & $\begin{array}{l}3,13 \\
(0,93)\end{array}$ & $\begin{array}{l}3,07 \\
(1,01)\end{array}$ & $\begin{array}{c}2,88 \\
(1,03)\end{array}$ & $\begin{array}{l}2,85 \\
(1,03)\end{array}$ & 0,000 \\
\hline $\begin{array}{l}\text { Eu gostaria de ter mais } \\
\text { aulas de Ciências na } \\
\text { escola }\end{array}$ & $\begin{array}{l}2,49 \\
(1,19)\end{array}$ & $\begin{array}{l}2,77 \\
(1,04)\end{array}$ & $\begin{array}{l}2,66 \\
(1,16)\end{array}$ & $\begin{array}{c}2,47 \\
(1,12)\end{array}$ & $\begin{array}{l}2,43 \\
(1,12)\end{array}$ & 0,000 \\
\hline $\begin{array}{l}\text { A ciência que aprendo } \\
\text { na escola me ensina a } \\
\text { cuidar melhor da minha } \\
\text { saúde }\end{array}$ & $\begin{array}{l}3,09 \\
(1,03)\end{array}$ & $\begin{array}{l}3,28 \\
(0,92)\end{array}$ & $\begin{array}{l}3,29 \\
(0,90)\end{array}$ & $\begin{array}{c}2,97 \\
(0,98)\end{array}$ & $\begin{array}{l}3,00 \\
(0,97)\end{array}$ & 0,000 \\
\hline
\end{tabular}

Fonte: Elaboração própria (2015) 
Tabela 6: Teste de Tukey com relação ao interesse pelas aulas de ciências, por região

\begin{tabular}{|c|c|c|c|}
\hline & $\begin{array}{c}\text { Teste de Tukey (grupos } \\
\text { diferentes) }\end{array}$ & Diferença & $\mathrm{p}$-valor \\
\hline \multirow{2}{*}{$\begin{array}{l}\text { Penso que todos deverão } \\
\text { aprender Ciências }\end{array}$} & Centro-Oeste $\neq$ Norte & 0,29 & \multirow[b]{2}{*}{0,000} \\
\hline & Norte $\neq$ Sul & 0,26 & \\
\hline \multirow{6}{*}{$\begin{array}{l}\text { Os conhecimentos que adquiro } \\
\text { nas aulas de Ciências serão } \\
\text { úteis na minha vida cotidiana }\end{array}$} & Centro-Oeste $\neq$ Sudeste & 0,20 & \multirow{6}{*}{0,000} \\
\hline & Centro-Oeste $\neq$ Sul & 0,17 & \\
\hline & Nordeste $\neq$ = Sudeste & 0,34 & \\
\hline & Nordeste $\neq$ Sul & 0,31 & \\
\hline & Norte $\neq$ Sudeste & 0,31 & \\
\hline & Norte $\neq$ Sul & 0,28 & \\
\hline \multirow{5}{*}{$\begin{array}{l}\text { Penso que a ciência que eu } \\
\text { aprendo na escola melhorará } \\
\text { as minhas oportunidades de } \\
\text { carreira }\end{array}$} & Centro-Oeste $\neq$ Sudeste & 0,24 & \multirow{5}{*}{0,000} \\
\hline & Nordeste $\neq$ Sudeste & 0,35 & \\
\hline & Nordeste $\neq$ Sul & 0,23 & \\
\hline & Norte $\neq$ Sudeste & 0,41 & \\
\hline & Norte $\neq$ Sul & 0,29 & \\
\hline \multirow{4}{*}{$\begin{array}{l}\text { As aulas de Ciências } \\
\text { aumentam o meu gosto pela } \\
\text { natureza }\end{array}$} & Nordeste $\neq$ Sudeste & 0,66 & \multirow{4}{*}{0,000} \\
\hline & Nordeste $\neq$ Sul & 0,28 & \\
\hline & Norte $\neq$ Sudeste & 0,19 & \\
\hline & Norte $\neq$ Sul & 0,22 & \\
\hline \multirow{4}{*}{$\begin{array}{l}\text { Eu gostaria de ter mais aulas } \\
\text { de Ciências na escola }\end{array}$} & Centro-Oeste $\neq$ Nordeste & 0,28 & \multirow{4}{*}{0,000} \\
\hline & Nordeste $\neq$ Sudeste & 0,30 & \\
\hline & Nordeste $\neq$ Sul & 0,34 & \\
\hline & Norte $\neq$ Sudeste & 0,19 & \\
\hline \multirow{4}{*}{$\begin{array}{l}\text { A ciência que aprendo na } \\
\text { escola me ensina a cuidar } \\
\text { melhor da minha saúde }\end{array}$} & Nordeste $\neq$ Sudeste & 0,31 & \multirow{4}{*}{0,000} \\
\hline & Nordeste $\neq$ Sul & 0,28 & \\
\hline & Norte $\neq$ Sudeste & 0,32 & \\
\hline & Norte $\neq$ Sul & 0,29 & \\
\hline
\end{tabular}

Fonte: Elaboração própria (2015)

Conjugando os dados obtidos com o conteúdo dos itens, os estudantes das regióes Norte $(3,29 \pm 0,97)$, Nordeste $(3,19 \pm 0,97)$ e Sudeste $(3,10 \pm 1,03)$ foram os que apresentaram maior média para a afirmação de que todos devem aprender ciências. Os jovens do Centro-Oeste, Nordeste e Norte reconheceram as aulas de ciências como uma área de conhecimento substancial para o seu cotidiano e na conquista de oportunidades para uma carreira. Quanto ao papel das aulas na 
aproximação da natureza, os jovens do Nordeste $(3,13 \pm 0,93)$ e Norte $(3,07 \pm 1,01)$ pareceram mais motivados do que os das demais regióes. Os jovens nordestinos e nortistas também apresentaram maior concordância quando ao interesse por mais aulas de ciências na escola e quanto à conexáo dos conhecimentos científicos aprendidos nas aulas aos cuidados com a saúde.

Esses dados concordam com os resultados encontrados por Santos-Gouw (2013) quanto à variedade de respostas por regióes, uma vez que na aplicação do questionário ROSE também se identificou maior pontuação dos estudantes nordestinos e nortistas para os itens referentes às aulas de ciências, apresentando maior motivaçấo e interesse pelos conhecimentos tratados na disciplina. Por outro lado, os estudantes do Sudeste e Sul apresentaram menor pontuação, o que não necessariamente representa atitudes negativas, pois as médias atingidas apontam para concordância diante dos itens.

As atitudes dos estudantes com relaçấo às aulas de ciência foram testadas a partir das variáveis socioeconômicas (número de banheiros e livros e instrução dos pais), conforme os resultados apresentados na tabela 7 .

Tabela 7: Teste de Kruskal-Wallis da relação dos jovens com as aulas de ciência por aspectos socioeconômicos

\begin{tabular}{|c|c|c|c|c|}
\hline \multicolumn{5}{|l|}{ Teste Kruskal-Wallis ( $p$-valor) } \\
\hline & $\begin{array}{l}\text { Número } \\
\text { Banheiros }\end{array}$ & $\begin{array}{l}\text { Número } \\
\text { Livros }\end{array}$ & Instrução Mãe & InstruçãoPai \\
\hline $\begin{array}{l}\text { Penso que todos deverão aprender } \\
\text { Ciências }\end{array}$ & 0,366 & 0,000 & 0,436 & 0,654 \\
\hline $\begin{array}{l}\text { Os conhecimentos que adquiro nas } \\
\text { aulas de Ciências serão úteis na } \\
\text { minha vida cotidiana }\end{array}$ & 0,000 & 0,006 & 0,000 & 0,000 \\
\hline $\begin{array}{l}\text { Penso que a ciência que eu } \\
\text { aprendo na escola melhorará as } \\
\text { minhas oportunidades de carreira }\end{array}$ & 0,252 & 0,067 & 0,000 & 0,012 \\
\hline $\begin{array}{l}\text { As aulas de Ciências estimulam } \\
\text { a minha curiosidade acerca das } \\
\text { coisas que ainda não conseguimos } \\
\text { explicar }\end{array}$ & 0,053 & 0,005 & 0,239 & 0,642 \\
\hline $\begin{array}{l}\text { As aulas de Ciências aumentam o } \\
\text { meu gosto pela natureza }\end{array}$ & 0,055 & 0,000 & 0,000 & 0,000 \\
\hline $\begin{array}{l}\text { Eu gostaria de ter mais aulas de } \\
\text { Ciências na escola }\end{array}$ & 0,000 & 0,000 & 0,006 & 0,052 \\
\hline $\begin{array}{l}\text { A ciência que aprendo na escola } \\
\text { me ensina a cuidar melhor da } \\
\text { minha saúde }\end{array}$ & 0,048 & 0,026 & 0,000 & 0,000 \\
\hline
\end{tabular}


Observa-se que houve diferença significativa ao nível de 5\% nas respostas dos estudantes por variáveis socioeconômicas, entretanto, condiçóes de moradia parecem influenciar em menor proporção do que as variáveis que representam recursos educacionais. Ao verificar a localização dos grupos diferentes (por meio do teste de Tukey), observaram-se duas situaçóes distintas, que podem ser exemplificadas pelas médias encontradas no item "Os conhecimentos que adquiro nas aulas de ciências serão úteis na minha vida cotidiana". Para o número de livros

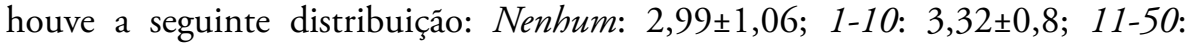

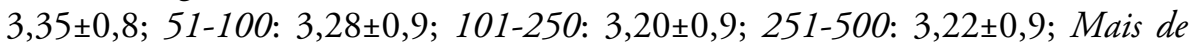
500: $3,36 \pm 1,0$.

Quanto à escolaridade da mãe, a distribuição encontrada para o item foi:

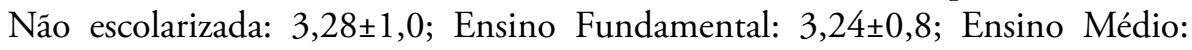

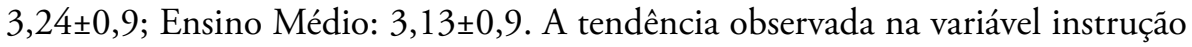
da mãe repete-se na escolaridade do pai: Não escolarizado: 3,35 $\pm 0,9$; Ensino

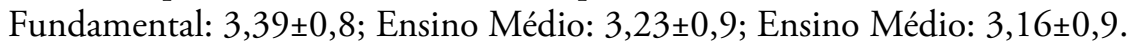

Enquanto o maior número de livros aumenta proporcionalmente as médias atingidas pelos jovens, a maior instruçáo dos pais reduz as médias, pois os estudantes cujos pais possuem Ensino Médio e Ensino Superior apresentaram médias mais baixas quanto ao interesse e preferência pelas aulas de ciências ou a sua relação com as experiências cotidianas. Esses resultados apontam que alguns grupos sociais demonstram sentimentos de insatisfação com maior frequência com o que é oferecido e experimentado na escola.

De modo geral, na caracterização da relação dos jovens com a ciência, percebeu-se, primeiramente, que diferentes espaços e fontes de informação atuam em conjunto com a escola; no entanto, o acesso a determinados espaços de informação científica é limitado por condições socioeconômicas e aspectos regionais. Nesse último, infere-se que existam poucos centros e museus científicos nos diferentes pontos do país. Por outro lado, o hábito ou consumo informativo fora do espaço escolar é baixo entre os brasileiros, o que pode representar, como afirma Christidou (2011), pouco compromisso com a ciência, tendo em vista que a participação e a busca pela ciência fora da escola parecem associadas ao compromisso e percepçóes positivas diante de temas científicos.

No tocante às atitudes em relação às aulas de ciências, houve forte concordância com os itens referentes à importância da ciência para o cotidiano dos jovens. A maioria dos estudantes, sobretudo as meninas e os estudantes do Nordeste e Norte, percebeu a relaçáo entre o que é aprendido em sala de aula com a questáo da própria saúde, os aspectos ambientais e a relevância da ciência para futuras oportunidades de emprego. Em contrapartida, os estudantes apresentam baixo interesse por questóes científicas fora da escola, o que pode ser evidenciado 
pelo hábito informativo dos pesquisados. Mesmo que os jovens reconheçam a importância da ciência e o seu papel para o cotidiano, a proporçáo de interessados em aprofundar sobre o tema em outros espaços de informação parece menor.

As opinióes dos jovens brasileiros divergem dos resultados encontrados em outros países, pois geralmente os estudantes apresentam posiçóes positivas acerca do papel da ciência para a sociedade, mas expressam sentimentos negativos diante da ciência escolar (SJØBERG; SCHREINER, 2005). Apreciação da ciência fora escola não reflete nas respostas sobre a relevância da ciência escolar, ou um desejo a ter empregos que envolvam a ciência (BENNETT; HOGARTH, 2009).

Awan et. al. (2011) comentam que as atitudes dos jovens sobre ciência variam consideravelmente em diferentes partes do mundo, ou seja, os estudantes de países em desenvolvimento parecem mais interessados pela ciência e temas relacionados com a ciência do que os jovens de países desenvolvidos, que mostram pouco interesse pelo assunto. De modo geral, os dados brasileiros refletem os resultados de países em desenvolvimento, nos quais se destacam posiçóes positivas dos estudantes também ao se refere à ciência escolar.

Sjøberg e Schreiner (2005) destacam que estudantes de países de baixo IDH (Índice de Desenvolvimento Humano) geralmente apresentam maior interesse pela ciência quando comparados com os jovens oriundos de países bem desenvolvidos. Os autores avaliam essas tendências como resultado de uma perspectiva geral de melhorias de condiçóes de vida, pois a ciência passa a ser compreendida como uma possibilidade de melhoria de condiçóes materiais e de crescimento econômico.

Diante dos resultados encontrados na presente pesquisa, é necessário destacar algumas limitaçóes do uso de métodos quantitativos, pois os dados sugerem alguns indicadores das opinióes dos jovens, pontuando sentimentos positivos ou negativos, no entanto, as escalas não contribuem ao compreender as razóes que influenciam as atitudes dos jovens acerca das aulas de ciências. Concorda-se com Awan et. al. (2011) quando escrevem que as escalas de atitude sobre ciência e tecnologia presentes em questionários, embora úteis ao identificar a natureza do problema, têm sido de pouca ajuda para entendê-lo. Nesse contexto, a associação de abordagens quantitativas e qualitativas poderia ajudar os pesquisadores a explorar e entender os determinantes de atitudes positivas e negativas.

Dessa forma, pauta-se o desafio em estudos futuros de compreender os significados da alta apreciação das aulas de ciências dos jovens brasileiros e quais recursos escolares e culturais estâo envolvidos nas percepçóes positivas dos estudantes acerca das aulas de ciências, e que ao mesmo tempo não incentivam a busca pela ciência em outros espaços de informação. 


\section{Referências}

AWAN, R. et al. Attitudes toward science among school students of different nations: A review study. Journal of College Teaching \& Learning (TLC), v. 8, n. 2, p. 43-50, 2011.

BENNETT, J.; LUBBEN, F; HOGARTH, S. Bringing science to life: A synthesis of the research evidence on the effects of context-based and STS approaches to science teaching. Science \& Education, v. 91, n. 3, p. 347-370, 2006.

BENNETT, J.; HOGARTH, S. Would you want to talk to a scientist at a party? High school students' attitudes to school science and to science. International Journal of Science Education, v. 31, n. 14, p. 1975-1998, 2009.

CHRISTIDOU, V. Interest, attitudes and images related to science: Combining students' voices with the voices of school Science, teachers, and popular Science. International Journal of Environmental \& Science Education, v. 6, n. 2, p. 141-159, 2011.

COURI, C. Nível socioeconômico e cor/raça em pesquisas sobre efeito-escola. Est. Aval. Educ., v. 21, n. 47, p. 449-472, 2010.

DANAIA, L.; FITZGERALD, M.; MCKINNON, D. Students' Perceptions of High School Science: What has Changed Over the Last Decade? Research in Science Education, v. 43, p. 1.501-1.515, 2013.

ESHACH, H. Bridging in-school and out-of-school learning: Formal, non-formal, and informal education. Journal of science education and technology, v. 16, n. 2, p. 171-190, 2007.

FALLIK, O.; ROSENFELD, S.; EYLON, B. School and out-of-school science: A model for bridging the gap. Studies in Science Education, v. 49, n. 1, p. 69-91, 2013.

JIDESJÖ, A.; OSCARSSON, M.; KARLSSON, K. G.; STRÖMDAHL, H. Science for all or science for some: What Swedish students want to learn about in secondary science and technology and their opinions on science lessons. Nordic Studies in Science Education, v. 5, n. 2, p. 213-229, 2009.

KIESLER, C. A.; COLLINS, B. E.; MILLER, N. Attitude change: a critical analysis of theoretical approaches. New York: John Wiley \& Sons, 1969. 377 p.

LOGAN, M.; SKAMP, K. Engaging students in science across the primary secondary interface: Listening to the students' voice. Research in Science Education, v. 38, n. 4, p. 501-527, 2008. 
LYONS, T. Different countries, same science classes: Students' experiences of school science in their own words. International Journal of Science Education, v. 28, n. 6, p. 591-613, 2006.

MASSARANI, L.; MOREIRA, I. C. Ciência e público: reflexôes sobre o Brasil. Redes, v. 15, n. 30, p. 105-124, 2009.

MOTA, H. S. Evoluçáo Biológica e Religiáo: atitudes de jovens estudantes brasileiros. 2013. 275p. Tese (Doutorado em Educação) - Faculdade de Educação, Universidade de São Paulo, São Paulo, 2013.

OSBORNE, J.; COLLINS, S. Students' views of the role and value of the science curriculum: a focus-group study. International Journal of Science Education, n. 23, p. 441-467, 2001.

QUINN, F.; LYONS, T. High School Students Perceptions of School Science and Science Careers: A Critical Look at a Critical Issue. Science Education International, v. 22, n. 4, p. 225-238, 2011.

SANTOS-GOUW, A. M. As opinióes, interesses e atitudes dos jovens brasileiros frente à ciência: uma avaliação em âmbito nacional. 2013. 242p. Tese (Doutorado em Educação) - Faculdade de Educaçáo, Universidade de São Paulo, São Paulo, 2013.

SIMPSON, J. S.; PARSONS, E. C. African American perspectives and informal science educational experiences. Science Education, v. 93, n. 2, p. 293-321, 2009.

SJØBERG, S.; SCHREINER, C. Update on the ROSE project: Students perceptions of science and technology. IOSTE Newsletter, v.8, n.1, p. 7-10, 2005.

VAN AALDEREN-SMEETS, S. I.; WALMA VAN DER MOLEN, J. H.; ASMA, Lieke J. F. Primary teachers' attitudes toward science: A new theoretical framework. Science Education, v. 96, n. 1, p. 158-182, 2012.

VOGT, C. A.; CASTELFRANCHI, Y. Interesse, informação e comunicação: Cultura científica em Iberoamérica: encuesta em grandes núcleos urbanos. In: ALBORNOZ, M.; MARCHESI ULLASTRES, A.; ARANA, L. Cultura científica en Iberoamérica. Encuesta en grandes núcleos urbanos. Proyecto Estándar Iberoamericano de Indicadores de Percepción Pública, Cultura Científica y Participación Ciudadana (2005-2009), 2009, p. 21-36.

VOGT, C.; MORALES, A. P.; RIGHETTI, S.; CALDAS, C. Hábitos informativos sobre ciência e tecnologia. In: POLINO, C. Los estudiantes y la ciencia: encuesta a jóvenes ibero-americanos. Buenos Aires: Organización de Estados Iberoamericanos para la Educación, la Ciencia y la Cultura, 2011, p. 155-182. 



\title{
Aprendizagem da docência na formação inicial de professores: estudar para ensinar matemática
}

\author{
Teaching of learning in initial teacher education: need and \\ sense of studying to teach mathematics
}

\author{
Simone POZEBON ${ }^{1}$ \\ Anemari Roesler Luersen Vieira LOPES²
}

\begin{abstract}
Resumo
Este artigo apresenta resultados de uma pesquisa com acadêmicos de Licenciatura em Matemática e Pedagogia em um projeto desenvolvido com alunos do Ensino Fundamental em uma escola de rede pública estadual do Rio Grande do Sul. Com o objetivo de discutir sobre a aprendizagem da docência desses futuros professores, coletaram-se os dados a partir de gravaçóes de áudio e vídeo, analisando-os por meio de seleçáo de episódios. A análise permitiu identificar indícios reveladores de aprendizagem da docência em dois aspectos principais: a necessidade dos futuros professores de estudar o conteúdo a ser ensinado e o sentido atribuído por eles a essa ação.
\end{abstract}

Palavras-chave: Formação de Professores. Educação Matemática nos Anos Iniciais. Atividade Orientadora de Ensino.
Abstract

This article presents results of a survey with students of Graduation in Mathematics and Pedagogy in a project developed with students in the early years of primary education in a public state school in Rio Grande do Sul. Aiming to discuss the teaching training of these future teachers, we collected the data from audio and video recordings, being the systematization movement performed by selection of episodes. This analysis revealed telltale evidence of teaching learning in two main aspects: the need for future teachers to study on the content to be taught and the meaning attributed by them to this action.

Keywords: Teachers training. Mathematica education in the early years. Teaching guiding activity.

1 Doutoranda em Educação do Programa de Pós-Graduação em Educação da Universidade Federal de Santa Maria (UFSM). Licenciada em Matemática e Mestre em Educação pela mesma Instituição. Av. Roraima, no 1000, Bairro Camobi, Santa Maria/RS. CEP: 97105-900. E-mail: <spozebon@gmail. com>.

2 Doutora em Educação (FE-USP). Professora Adjunta do Departamento de Metodologia do Ensino e do Programa de Pós-Graduação em Educação e do Programa de Pós-Graduação em Educação Matemática e Ensino de Física da Universidade Federal de Santa Maria (UFSM). Av. Roraima, no 1000, Bairro Camobi, Santa Maria/RS. CEP: 97105-900. E-mail: <anemari.lopes@gmail.com>.

R. Educ. Públ.
Cuiabá

v. 28

n. 67

p. $219-238$ jan./abr. 2019 


\section{Introdução}

Em uma obra clássica do início do período em que se acentuaram as discussóes sobre Educação Matemática no Brasil, Ubiratan D’Ambrosio (1986) escreveu que as formas de ensino do conhecimento matemático contribuem para que essa disciplina seja vista como complexa, o que gera dificuldades de aprendizagem e altos índices de reprovação. Destacou, ainda, que os problemas não se referem apenas às dificuldades dos alunos: implicam também dificuldades encontradas pelos professores, que, muitas vezes, não conseguem aprofundar-se nos conhecimentos necessários para a sua prática docente. Passadas quase três décadas dessa afirmação, embora não possamos negar que tenham ocorrido muitos avanços, a mesma preocupaçáo de D`Ambrosio continua mobilizando professores e pesquisadores, que buscam tanto compreender esse processo quanto desenvolver açóes que universalizem a aprendizagem da Matemática.

Encontramo-nos nesse contexto como professoras de cursos de licenciatura e pesquisadoras que participam de um projeto interinstitucional ${ }^{3}$ (financiado pelo OBEDUC/CAPES) que investiga princípios e práticas da organização do ensino de Matemática para os anos iniciais do Ensino Fundamental. Esse projeto é desenvolvido por quatro instituiçôes de diferentes regióes do Brasil, e estão vinculadas a ele diversas ações e investigaçóes, porém, especificamente neste artigo, traremos resultados de uma pesquisa desenvolvida pela primeira autora e orientada pela segunda, que versou sobre formação inicial de professores.

A organização do ensino tem um papel fundamental para os professores que ensinam Matemática e, diante disso, referenciamo-nos teórica e metodologicamente na Atividade Orientadora de Ensino (AOE) (MOURA, 1996, 2001), uma proposta para o trabalho do professor embasada na Teoria Histórico-Cultural e também uma possibilidade de realizar a atividade educativa, tendo como base o conhecimento produzido sobre os processos humanos de construção de conhecimento (MOURA et al., 2010).

Amparadas por esses pressupostos, defendemos a necessidade e a possibilidade de organizar o ensino visando à apropriação de conhecimentos que promovam o desenvolvimento das funçóes psíquicas superiores dos educandos. Assim, compete ao professor que ensina Matemática propor situaçóes desencadeadoras

3 Projeto "Educaçấo Matemática nos Anos Iniciais do Ensino Fundamental: princípios e práticas da organizaçáo do ensino", OBEDUC/PPOE, desenvolvido em parceria com a Universidade de São Paulo, campus São Paulo e campus Ribeirão Preto, a Universidade Federal de Santa Maria e a Universidade Federal de Goiás. 
de aprendizagem aos alunos, levando em consideração os conteúdos e os conceitos a serem trabalhados, de forma que essas situaçóes possam mobilizar os docentes em direção à concretização dos objetos próprios do ensino e da aprendizagem.

O lócus da investigação aqui apresentada refere-se a um projeto - vinculado ao citado anteriormente - que acontece em parceria com escolas da rede estadual de ensino do Rio Grande do Sul, em que estudantes dos cursos de Licenciatura em Matemática e Pedagogia se reúnem semanalmente para estudar, planejar, desenvolver e avaliar atividades de ensino de Matemática. Com o objetivo de discutir sobre a aprendizagem da docência de futuros professores, reportarnos-emos à organização de uma dessas atividades de ensino, que versava sobre grandezas e medidas e foi desenvolvida com alunos do terceiro ano do Ensino Fundamental. Mais especificamente, direcionaremos nosso olhar ao momento de estudo, que visa subsidiar teoricamente o trabalho a ser realizado, no que diz respeito ao conhecimento matemático envolvido nas atividades organizadas.

Para situar o leitor de onde falamos, inicialmente traremos de forma breve os pressupostos teóricos que fundamentaram a pesquisa. Posteriormente, apresentaremos episódios extraídos das açóes dos acadêmicos, onde encontramos indícios reveladores de aprendizagem da docência. Finalizando, traçaremos algumas consideraçóes acerca do estudo, orientadas principalmente por dois aspectos observados nos episódios: a necessidade dos futuros professores de estudar sobre o conteúdo a ser ensinado e o sentido atribuído por eles a essa açáo.

\section{Os pressupostos teóricos norteadores da pesquisa}

Os fundamentos teóricos deste trabalho partem dos princípios da Teoria Histórico-Cultural, em especial, da ideia de que o homem se desenvolve e se torna humano por meio das suas relaçóes sociais com outros indivíduos e com o mundo exterior, decorrentes de um processo histórico. A partir de Vigotsky maior expoente dessa teoria - e seus colaboradores, entendemos que estar e viver em sociedade são necessidades específicas do ser humano nos sentidos biológico, histórico e cultural, pois, além de um ser social, o homem é um ser natural, que também é conduzido por leis biológicas. Tal como qualquer animal, o homem atende às suas necessidades orgânicas e vitais, mas, além disso, ele procura atender às condiçôes para o bem viver.

As necessidades humanas podem ser satisfeitas por meio de uma açáo intencional: o trabalho. Os pressupostos da Teoria Histórico-Cultural, que se fundamentam na perspectiva materialista histórico-dialética, destacam o trabalho como um alicerce para a construção e o desenvolvimento de qualquer sociedade, 
o elemento essencial na humanizaçáo de qualquer indivíduo e entendido como uma atividade humana orientada por objetivos para chegar a um determinado fim. Compreendemos, então, assim como Moretti (2007, p.101), que,

[...] se, dentro da perspectiva histórico-cultural, o homem se constitui pelo trabalho, entendendo este como uma atividade humana adequada a um fim e orientada por objetivos, então o professor constitui-se professor pelo seu trabalho - a atividade de ensino - ou seja, o professor constitui-se professor na atividade de ensino.

Assim como nossa preocupação está na aprendizagem da docência do futuro professor, olhar para a organização da sua atividade (de ensino) tornase importante para compreender o seu movimento de formação. E, ao pensar no desenvolvimento e na constituição do professor, apoiamo-nos em Vigotsky (1994), para quem o ser humano desenvolve suas funçôes psicológicas superiores por intermédio das relaçóes com outros indivíduos de sua espécie; e em Leontiev (1978), que afirma não ser suficiente o que a natureza proporciona ao ser humano no seu nascimento para ele viver em sociedade; é preciso que cada indivíduo aprenda a ser homem. Para isso, é necessário que ele se aproprie do que foi construído e desenvolvido historicamente pela humanidade. Ou seja, o homem não nasce dotado das aquisiçóes históricas da sociedade humana, mas deve apropriar-se delas durante a sua vida para adquirir as propriedades e as faculdades verdadeiramente humanas. Toda a bagagem histórica e cultural elaborada pela humanidade somente se mantém viva por meio da sua transmissão e da apropriação pelas geraçóes posteriores, em um processo de comunicação e interação social, no qual a educação escolar tem um papel preponderante.

A apropriação da cultura pelas geraçóes é possível a partir do desenvolvimento das funçôes psicológicas superiores, especificamente humanas, mediatizadas e produzidas nas relaçóes interpessoais e históricas do homem com a cultura. Vigotsky (1994) refere-se às ferramentas psicológicas que, diferentemente das ferramentas materiais (condutoras das influências humanas sobre objetos de atividade ferramentas externamente orientadas), são internamente orientadas e transformam habilidades e competências humanas naturais em funçôes psicológicas superiores.

Nesse contexto, uma fonte propulsora e condição necessária para o desenvolvimento do homem, com suas funçóes psicológicas superiores, é a aprendizagem. Ambos - desenvolvimento e aprendizagem - não se acompanham de forma paralela, não se realizam em igual medida; e, como aponta Vigotsky (2001), a aprendizagem não é seguida pelo desenvolvimento, como a sombra segue o objeto que a projeta. 
Compreendemos, assim, que a diferença essencial entre o homem e os demais animais reside na aprendizagem com o indivíduo mais experiente, no desenvolvimento das funções psicológicas superiores (percepção, memorização, atenção, pensamento e imaginação) e no desenvolvimento de atividades (processo realizado a partir de uma necessidade particular do homem). Mas é importante ressaltar que, de acordo com nossa perspectiva teórica, nem toda ação que o indivíduo realiza se constitui como uma atividade de fato, pois se ela não estiver atendendo a uma necessidade particular do indivíduo, é considerada apenas uma ação ou tarefa. Caso não existam motivos e necessidades, também não haverá atividade. Portanto, a atividade constitui-se como tal mediante alguns elementos relacionados de forma específica, entre eles: motivos, necessidades, objetos, objetivos, açóes e operaçóes (LEONTIEV, 1978). O que dá origem à atividade é a manifestação de uma necessidade, que irá estabelecer as suas metas. O motivo, diferente da necessidade, é o que dirige a atividade, o que a estimula e impulsiona.

Outro aspecto relevante apresentado nessa teoria refere-se aos sentidos atribuídos pelos sujeitos a objetos, ações, etc. "O sentido é sempre uma formação dinâmica, fluida, complexa, que tem várias zonas de estabilidade variada." (VIGOTSKY, 2000, p. 465). O sentido de um objeto ou palavra é inesgotável; modifica-se de acordo com as vivências e a experiência do sujeito, traduzindo a sua relação com o objeto em questão por meio da sua definição pessoal. Em nosso trabalho, a compreensáo dos sentidos atribuídos pelos acadêmicos às açóes desenvolvidas faz-se importante, na medida em que podem tornar-se indicativos de sua aprendizagem quanto à organização do ensino.

Desse modo, tendo como suporte a Teoria Histórico-Cultural, compreendemos que os conhecimentos, dentre eles, o matemático, fazem parte da cultura humana e são construídos a partir das relaçóes sociais estabelecidas durante a sua história. Disso decorre o entendimento de que a Matemática se constitui como um conhecimento organizado e construído pela humanidade ao longo do tempo, com a finalidade de atender e satisfazer às necessidades que surgiram em determinado contexto e época histórica.

Como um produto de necessidades humanas, a Matemática insere-se no conjunto de elementos culturais que devem ser socializados, de modo a permitir a interação entre os sujeitos e possibilitar seu pleno desenvolvimento como homens. Assim sendo, os conhecimentos matemáticos podem contribuir de forma significativa para os alunos, pois, quando eles se envolvem em resolver os desafios que se apresentam nas atividades propostas na escola pelo professor, estáo se apropriando dos conhecimentos presentes nessa atividade, levando a novas aprendizagens que contribuem para o seu desenvolvimento. 
Nesse movimento, damos especial atenção para o papel do professor, ao organizar o ensino. $\mathrm{O}$ modo como irá desenvolver sua prática vai constituindose ao longo de sua história e pode ser modificado a partir de processos que lhe possibilitem aprender a ser professor. Para além de cursos de formaçáo inicial e continuada, o professor também aprende a partir da sua relação com o mundo, com os colegas e com seus alunos. E aprende no seu trabalho, na sua atividade de ensino.

Nessa perspectiva, entendendo o papel do professor no processo de ensino e aprendizagem, Moura $(1996,2001)$ propóe a Atividade Orientadora de Ensino (AOE) como um modo geral de organização do ensino, que possibilita a aprendizagem para alunos e professores. O termo Atividade Orientadora de Ensino designa uma atividade organizada intencionalmente, capaz de desencadear no aluno um conjunto de açóes que visam à solução coletiva de uma situaçãoproblema cujo objetivo é levar o sujeito à aprendizagem de um novo conceito. Para Moura (2001, p.155), ela

[...] se estrutura de modo a permitir que sujeitos interajam, mediados por um conteúdo, negociando significados, com o objetivo de solucionar coletivamente, uma situaçãoproblema. [...] a Atividade Orientadora de Ensino tem uma necessidade: ensinar; tem açôes: define o modo ou procedimentos de como colocar os conhecimentos em jogo no espaço educativo; e elege instrumentos auxiliares de ensino: os recursos metodológicos adequados a cada objetivo e ação (livro, giz, computador, ábaco, etc.). E por fim, os processos de análise e síntese, ao longo da atividade, são momentos de avaliação para quem ensina e aprende.

A AOE organiza-se de acordo com a estrutura da atividade proposta por Leontiev (1983) e, dessa forma, realiza-se por meio de finalidades - ensinar e aprender - e de ações que consideram as condições objetivas da escola (MOURA et al., 2010). É, portanto, uma unidade de formação do professor e do estudante, em que a função do professor é planejar açóes que se convertam em atividades e possibilitem a apropriaçáo dos conhecimentos e das experiências históricoculturais. O elemento fundamental, nesse processo, é a sua intencionalidade na organização e na concretização dos objetivos sociais do currículo escolar. Desse modo, aprender a ser professor não é apenas aprender o conteúdo a ser trabalhado, mas também fazer com que os conteúdos estejam, de alguma forma, acessíveis aos alunos. Tal premissa se torna particularmente importante quando nos propomos a investigar, como nesta pesquisa, o processo de formação de futuros professores. 
Contudo, a quantidade de conhecimentos produzidos em toda a história da humanidade é imensa e continua aumentando, o que inviabiliza um processo de ensino que possa propiciar o contato do estudante com o todo acumulado. Moura et al. (2010) apontam como soluçáo ensinar ao aluno um modo de ação generalizado, para acesso, utilização e criação do conhecimento. Dessa maneira, respeitando as especificidades de cada indivíduo e a partir da mediação do professor, é possível proporcionar a relaçáo entre o humano singular e o humano genérico no contexto educativo.

Como já afirmamos, a AOE compôe-se como proposta teórico-metodológica. Do ponto de vista teórico, ampara-se na Teoria Histórico-Cultural e na Teoria da Atividade; e, do metodológico, traz indicativos de elementos importantes para a organização do ensino. Destacamos, para esta nossa discussão, três deles: a Síntese Histórica do Conceito; a Situação Desencadeadora de Aprendizagem; e a Síntese da Solução Coletiva. O primeiro refere-se à organização e à constituição lógico-histórica, por parte da humanidade, do conceito a ser trabalhado, cuja compreensão pelo professor é essencial para a organização do ensino. O segundo concretiza-se na apresentação de um Problema Desencadeador de Aprendizagem aos alunos, a partir de uma Situação Desencadeadora de Aprendizagem (SDA), que mobilizará a turma a interagir para chegar a um nível elaborado de compreensão do conceito em questão. Esse movimento tem o objetivo de oportunizar a apropriação do conhecimento pelos alunos, de forma que contemple a gênese do conceito trabalhado. $O$ terceiro diz respeito aos alunos, quando, coletivamente, encontram a solução correta para o problema proposto. Nesse momento, a mediação deve levar os estudantes a respostas que coincidam com aquelas que a humanidade, ao longo da história, instituiu como corretas. A solução será construída a partir das interações mediadas pelos conhecimentos compartilhados no espaço de aprendizagem.

$\mathrm{Na}$ especificidade deste artigo, optamos por nos deter no primeiro momento, a Síntese Histórica do Conceito: futuros professores estudaram e discutiram acerca do conteúdo de grandezas e medidas, definido para uma atividade de ensino de Matemática que iriam desenvolver com alunos de uma escola de Educaçáo Básica. Apenas estudar a história, ler e conhecer sobre fatos que aconteceram de forma ilustrativa não contribui para a apropriação dos conceitos matemáticos. Ao adotarmos a AOE como premissa teórica e metodológica, entendemos a necessidade de uma organização do ensino que leve em consideração o caminho lógico e histórico percorrido pela humanidade na criaçáo dos conceitos matemáticos - no nosso caso, relativos a grandezas e medidas - e que coloque o aluno num movimento que lhe permita apropriar-se da essência desse conhecimento. 
Destacamos estas palavras de Kopnin (1978, p. 183-184):

Por histórico subentende-se o processo de mudança do objeto, as etapas de seu surgimento e desenvolvimento. O histórico atua como objeto do pensamento, o reflexo do histórico, como conteúdo. O pensamento visa à reprodução do processo histórico real em toda a sua objetividade, complexidade e contrariedade. O lógico éo meio através do qual o pensamento realiza essa tarefa, mas é o reflexo do histórico em forma teórica, vale dizer, é a reprodução da essência do objeto e da história do seu desenvolvimento no sistema de abstraçóes.

Compreendemos, assim, que o lógico é reflexo do histórico, ambos interdependentes; e, da mesma maneira, o histórico necessita da forma lógica de desenvolvimento para interpretá-lo. Segundo o autor anteriormente referido, para a revelação da essência do objeto, faz-se necessária a reprodução do processo histórico real de seu desenvolvimento, e esse só é possível ao conhecermos, então, o cerne do objeto - nesse caso, o conhecimento matemático, constituindo, desse modo, um ciclo de interdependência. $\mathrm{O}$ estudo da história nessa perspectiva, faz-se, portanto, necessário para atingir um grau mais elevado de conhecimento do objeto em questáo.

Além da história do objeto, o lógico traz o reflexo da história do seu conhecimento. "A unidade entre o lógico e o histórico é premissa metodológica indispensável na solução dos problemas da inter-relaçáo do conhecimento e da estrutura do objeto e conhecimento da história e seu desenvolvimento." (KOPNIN, 1978, p. 186). Como ressalta o autor, a unidade entre o lógico e o histórico torna-se uma premissa necessária para a total compreensão do movimento do pensamento.

Apresentados os pressupostos teóricos e metodológicos que orientam nossas ações no lócus de pesquisa, na próxima seção traremos episódios que, constituídos a partir dos momentos de estudos dos futuros professores, nos permitam discutir sobre a sua aprendizagem.

\section{O movimento de estudar para planejar: possibilidades para a aprendizagem da docência}

Como já explicitado, ao nos propormos a discutir sobre a aprendizagem da docência de futuros professores, o fazemos acompanhando um projeto desenvolvido em parceria entre a nossa universidade e escolas da rede pública estadual de ensino do estado do Rio Grande do Sul. Desse projeto, fazem 
parte professores universitários; professores da Educação Básica; estudantes de pós-graduação e de graduação. Sua dinâmica acontece a partir de estudo, planejamento, desenvolvimento e avaliaçáo de atividades de ensino de Matemática realizadas semanalmente com alunos dos anos iniciais do Ensino Fundamental, no horário regular das aulas - o que é possível devido à dimensão colaborativa de envolvimento das professoras regentes das turmas.

Embora a maior parte das açóes seja realizada de forma compartilhada, com a participação de todos os integrantes, nosso foco estará nas açóes dos sete acadêmicos, futuros professores, estudantes dos cursos de licenciatura em Matemática e Pedagogia, durante toda a organizaçáo de uma atividade sobre grandezas e medidas para ser desenvolvida com alunos do terceiro ano do Ensino Fundamental.

Os dados da pesquisa foram coletados em 15 encontros $^{4}$ a partir de gravaçóes de áudio e vídeo e, para sua análise, utilizamos o conceito de episódios proposto por Moura (1992, 2000, 2004), na expectativa de que sejam reveladores sobre a natureza e a qualidade das açóes. Eles se compóem de "frases escritas ou faladas, gestos e açóes que constituem cenas que podem revelar interdependência entre os elementos de uma ação formadora" (MOURA, 2004, p. 276), podendo ser definidos como "aqueles momentos em que fica evidente uma situação de conflito que pode levar à aprendizagem do novo conceito" (MOURA, 1992, p.77).

Apresentaremos dois episódios em que identificamos indícios de aprendizagem da docência, extraídos dos dois primeiros encontros do grupo que se preparava para organizar a atividade, na etapa inicial, que denominamos de "estudo", e objetiva a discussão sobre o conteúdo matemático a ser trabalhado, visando à organizaçáo do ensino para os alunos dos anos iniciais. Compóe-se de açôes a partir de referências bibliográficas da Matemática e da história da Matemática, dos pressupostos da AOE, da Teoria da Atividade e da Teoria Histórico-Cultural. Também nos reportaremos a algumas falas extraídas do terceiro encontro.

4 Cada atividade de ensino desenvolvida neste projeto (que envolve estudo, planejamento, desenvolvimento e avaliação) tem duraçấo variável e depende de aspectos como: conteúdo matemático envolvido, tipo de açóes planejadas, envolvimento dos alunos dos anos iniciais com os quais estamos trabalhando, entre outros. 


\section{Episódio 1 - A necessidade de estudar}

Este episódio desenvolveu-se no primeiro encontro e, como estávamos iniciando o trabalho, decidimos realizar com os acadêmicos uma Situaçáo Desencadeadora de Aprendizagem de uma atividade de ensino denominada Atividade da Rapunzel, já desenvolvida no ano anterior pelo mesmo grupo, com os alunos dos anos iniciais. $\mathrm{O}$ mesmo problema desencadeador apresentado às crianças daquela vez foi, agora, proposto para os acadêmicos. A SDA inicia com uma história virtual ${ }^{5}$, e o problema - que envolvia personagens da história consistia em descobrir por que o Gigante e os anóes, ao seguirem um certo mapa desenhado pela Bruxa, com indicações de medidas em passos, não conseguiram chegar ao local desejado, onde estava presa a personagem Rapunzel.

Cada um dos futuros professores resolveu individualmente o problema proposto e leu sua resposta. A partir disso, tiveram início a discussão e a reflexão sobre a atividade, que podemos acompanhar a seguir ${ }^{6}$ :

1.1. Pesquisadora: Pensando nessa atividade [da Rapunzel], qual o conceito que está nela, qual o conceito que as crianças aprenderam, se apropriaram, a partir desta atividade?

1.2. Todos: Unidade de comprimento, uma medida-padrão para a unidade de comprimento.

1.3. Orientadora: Mas nós não falamos de "metro" para as crianças. Só o problema desencadeador, da forma como foi encaminhado, não fala de metro. Vocês chegaram, na atividade, ao metro, mas como se chegou ao metro?

1.4. Pedro: Eu acho que, com essa atividade aqui, os alunos perceberam que existe uma necessidade de padronização, é isso, só isso.

1.5. Pesquisadora: Como um resultado posterior, surgiu o metro.

1.6. Orientadora: Então, será que podemos responder à pergunta: "Por que surgiu o metro?"

5 A história virtual é aqui compreendida como uma narrativa que proporciona ao estudante a possibilidade de envolver-se na soluçáo de um problema coletivo, tendo como finalidade a satisfaçáo de uma determinada necessidade, semelhante ao que pode ter acontecido em certo momento histórico com a humanidade (MOURA et al., 2010). Ou seja, é um dos modos que utilizamos para apresentar para as crianças um problema desencadeador de aprendizagem.

6 Os acadêmicos que participaram da pesquisa escolheram nomes fictícios para manter o anonimato. Ao aceitarem participar da pesquisa, eles assinaram o Termo de Consentimento Livre e Esclarecido, atendendo às orientaçóes do Comitê de Ética em Pesquisa da nossa instituição. 
1.7. Pedro: Como a resposta de uma necessidade.

1.8. Sabrina: Essa atividade foi a introdução do trabalho com essa unidade, porque a gente falou do metro, mas depois de toda essa introdução.

1.9. Pesquisadora: Mas quando ele criou o metro, quando sentiu a necessidade de padronizar as medidas? O homem já media antes disso, mas por que ele media? Por que o homem começou a medir?

1.10. Pedro: Ao se pensar nas civilizaçóes antigas, a necessidade de medir estava na delimitação de terras, mas isso ao pensar a partir do momento que o homem se torna nômade e começa a se constituir como sociedade [...] mas, ao se pensar antes disso, se o homem já media antes disso, se já sentia a necessidade antes disso...

1.11. Sabrina: Ele utilizava as partes do corpo antes também.

1.12. Orientadora: Mas por quê?? Por que o homem começou a medir?

1.13. Pesquisadora: Por que o primeiro homem ou os primeiros homens começaram a medir?

1.14. Sabrina: Porque ele sentiu a necessidade de medir.

1.15. Orientadora: Sentiram a necessidade por quê? Ou melhor, vou fazer outra pergunta: o que é medir? Aqui estamos falando sobre medida de comprimento, mas o que é medir?

1.16. Pedro: Medir é contar.

\subsection{Orientadora: Contar o quê?}

1.18. Pedro: É contar uma unidade estipulada para medida, porque para cada medida eu vou ter uma unidade estipulada; por exemplo, não vou contar horas em metro... medir é contar uma unidade que foi estipulada, convencionada historicamente.

1.19. Orientadora: $N a$ verdade, não estou dizendo que é certo nem errado, só quero que pensemos sobre isso.

1.20. Pesquisadora: De que forma podemos ter certeza se isto está correto, porque não podemos simplesmente afirmar uma informação. Você pode afirmar que medir é isso?

1.21. Pedro: Eu só acho que é.

1.22. Pesquisadora: E como verificamos se é isso mesmo? Como podemos verificar a definição de medir, grandeza, medida? 
1.23. Orientadora: Vocês já falaram que são padróes, se são padróes alguém estabeleceu, como a gente vai saber que o padrão é esse?

1.24. Pesquisadora: De que forma a gente conhece esses padróes?

\subsection{Beatriz: Através do estudo.}

1.26. Orientadora: Porque, se eles são padröes, alguém estabeleceu. Então, se são padrôes e foram estabelecidos por alguém, esse alguém é o sujeito humano... se o homem fez, o fez a partir das necessidades, e se alguém fez, uma determinada sociedade fez. Como a gente sabe que isso é dessa forma, hoje?

[...]

1.27. Beatriz: Temos que estudar, buscar referenciais teóricos... sobre os padröes criados pelo homem.

Nesse episódio, tentamos desenvolver uma atividade na perspectiva da AOE com os acadêmicos, buscando avaliá-la para pensar numa nova proposta a ser elaborada. $\mathrm{O}$ intuito era refletirmos se aquela atividade tinha realmente atendido ao objetivo de levar os alunos dos anos iniciais a apropriarem-se do movimento do surgimento da necessidade de medir. Nas primeiras discussóes, os acadêmicos atentaram para o fato de que replanejar uma atividade de ensino sobre os conceitos iniciais referentes ao que queríamos trabalhar envolveria, necessariamente, o estudo mais aprofundado sobre o tema, a constituição histórica dos conceitos e suas definiçóes e propriedades matemáticas.

Em sequência às falas apresentadas, ocorreu mais um momento de discussóes, em que o desencadeamento do diálogo nos possibilitou apontar algumas consideraçóes acerca das necessidades que ficaram evidentes na resolução do problema e nos motivos que mobilizaram os futuros professores. Ao discutirem sobre a Atividade da Rapunzel e os conteúdos matemáticos que ela envolveu, constataram uma falha: a atividade náo enfatizava a necessidade do ato de medir - partia direto para a padronização das unidades. Com essa nova ideia, até então não abordada no grupo, os acadêmicos, em suas falas, atentaram, de uma forma geral, para o fato de que não possuíam subsídios teóricos para elaborar e desenvolver uma atividade. E isso os levou à ação seguinte - estudar sobre grandezas e medidas.

Chamamos a atenção para o fato de que essa ação de estudar estava relacionada à organização do ensino e, sendo assim, em relação intrínseca com a aprendizagem para a docência. Sobre o professor em formação inicial, fica claro na afirmação de Lopes (2009, p.178) que 
[...] a constatação da necessidade de buscar conhecimentos, no sentido de aprender para ensinar, pode constituir-se como aprendizagem na medida em que o futuro professor toma consciência da importância de assumir a formação como um processo dinâmico, em constante reelaboraçáo.

Desse modo, a conclusão, pelos estudantes, de que se fazia necessário um estudo para organizar o seu ensino pode indicar que suas preocupaçóes se direcionem ao fato de tornar-se professor, pois visavam à aprendizagem por parte dos seus alunos. O que podemos observar, assim, é a existência de um motivo que mobilizou os estudantes a uma direção concreta: a elaboração da atividade de ensino. Ao destacar, especialmente na fala 25 , de Beatriz, que só "tomamos conhecimento das informaçôes imprescindiveis para o planejamento da escola através do estudo", percebemos que os motivos que impulsionaram e orientaram as açóes de estudo dos acadêmicos podem ser considerados geradores de sentido, na medida em que, ao estimular a atividade, conferiram-lhe sentidos pessoais (dos futuros professores) acerca da importância e da necessidade do estudo. E, além de buscar o aprendizado individual, todos tinham como intuito estudar e planejar coletivamente uma atividade que se adequasse às características da AOE.

Assim, evidenciamos a relaçáo entre os motivos dos estudantes e as necessidades que surgiram para o estudo. Podemos identificar que, a partir da necessidade de apropriar-se de conhecimentos para poder organizar o ensino, o motivo que os levou a estudar coincide com o objeto da atividade de estudar, que é apropriar-se do conteúdo. Isso nos leva a inferir que o estudo desenvolvido posteriormente pelos futuros professores pode ter-se constituído como uma atividade de aprendizagem, na perspectiva dos pressupostos que aqui adotamos.

\section{Episódio 2 - Onde buscar subsídios teóricos para o estudo}

No episódio apresentado anteriormente, os acadêmicos concluíram que, durante a Atividade da Rapunzel, foi destacada apenas a padronizaçáo de unidades de medida para comprimento, pois somente após o estabelecimento de uma unidade como padrão social foi instituído o metro. Entretanto, quando isso aconteceu, o homem já sabia medir. A partir disso, foram discutidos com o grupo vários aspectos: como o homem media antigamente, o que é medir, o que podemos medir, como conhecemos as mediçóes realizadas pelo homem ao longo da história. A reflexão dos acadêmicos possibilitou compreender que temos acesso aos conhecimentos por meio dos registros de épocas e sociedades passadas. 
No segundo encontro, retomamos as discussóes anteriores e propusemos uma nova pergunta: "Como fazemos para resgatar e conhecer os registros?"

2.1. Orientadora: Como fazemos para resgatar os registros?

2.2. Sabrina: Estudando, vivenciando, através da sintese histórica, é o que a gente tenta fazer; primeiro a gente faz um estudo teórico para ver como que a bumanidade foi se apropriando, depois faz uma tentativa de tentar fazer com que as crianças experienciem isso [...] pra ir se apropriando desse processo.

2.3. Branca: A gente usa e vai se apropriando de outras ideias já existentes, vai modificando conforme as nossas necessidades também.

$[\ldots]$

2.4. Orientadora: $O$ que seria esse estudo teórico em Matemática?

2.5. Branca: Como surgiu a necessidade do conteúdo, no caso da medida, qual foi a necessidade que o homem sentiu de medir.

2.6. Pedro: É importante este estudo da gênese do conceito [...] mas, num segundo momento, o estudo do conteúdo em si [...], o modo como eu vou abordar esse conteúdo com os alunos, a linguagem que eu vou usar pra ser uma linguagem que o aluno entenda, mas que não fuja da linguagem matemática [...]

2.7. Pesquisadora: Da forma como fizemos o estudo na [atividade] da Rapunzel, vocês acham que contemplou essa parte histórica e do conteúdo matemático?

2.8. Orientadora: $A$ necessidade de medir ficou respondida através desse problema desencadeador?

2.9. Pedro: Foi introduzida, eu acho.

2.10. Pesquisadora: Qual foi o conceito que a gente trabalhou nessa atividade?

2.11. Todos: Padronização.

2.12. Orientadora: E a necessidade de medida? Nós trabalhamos aqui?

2.13. Caroline: Se nem a gente sabe responder agora, acho que muito menos as crianças conseguiräo isso.

2.14. Orientadora: Será que não está faltando isso, quando a gente pensar em medidas?

2.15. Pesquisadora: Temos subsidios, condiçôes de responder agora qual foi essa necessidade do homem de medir?

2.16. Branca: Não. (Os outros concordam) 
2.17. Pesquisadora: E o que a gente pode fazer para atender essa necessidade nossa?

2.18. Beatriz: Estudar.

2.19. Pesquisadora: Boa ideia, mas de que forma a gente pode estudar?

2.20. Orientadora: Podemos, então, pegar um livro de Matemática do $5 .^{\circ}$ ano?

2.21. Pedro: Pra esse momento, não.

2.22. Pesquisadora: A gente vai encontrar essa resposta em um livro didático?

2.23. Branca: Não.

2.24. Pedro: $O$ que a gente tá procurando não, pra esse momento de estudo, não.

2.25. Pesquisadora: $O$ que a gente tem que procurar?

2.26. Pedro: Fontes que tragam essa retomada histórica.

Nesse episódio, ficaram evidentes as ações que o grupo apontou como solução para ter condiçóes de planejar novamente uma atividade sobre o conteúdo de grandezas e medidas. E, após esse encontro, um primeiro passo partiu dos estudantes: a realização de um estudo para subsidiar a elaboração de uma atividade que evidenciasse a necessidade de medir esse estudo, relacionado aos aspectos lógico e histórico do surgimento e sistematização do conceito de medir e também à melhor forma de trabalhá-los com as crianças.

A partir dessa etapa de encaminhamento das açóes, mais especificamente do diálogo anteriormente relatado, podemos assinalar algumas consideraçóes que julgamos relevantes.

Em relação ao conhecimento que o professor precisa ter para ensinar, as falas da acadêmica Sabrina, na linha 2, e da acadêmica Caroline, na linha 13, enfatizam a importância de o professor ter experiências e apropriar-se do conceito matemático, para, somente depois disso, ter condiçóes de desenvolver atividades em que os alunos também passem por esse processo de construção. Esse movimento de apropriaçáo do conhecimento, ao ser assumido como um elemento importante para o planejamento das aulas, pode promover a aprendizagem da docência e o desenvolvimento do sujeito. Moura et al. (2010, p. 90) afirmam que

[...] o professor que se coloca, assim, em atividade de ensino continua se apropriando de conhecimentos teóricos que lhe permitem organizar açóes que possibilitem ao estudante a apropriaçáo de conhecimentos teóricos explicativos da realidade e o desenvolvimento do seu pensamento teórico, ou seja, açóes que promovam a atividade de aprendizagem de seus estudantes. 
Sobre o estudo do professor, as falas dos estudantes, em especial nas linhas 2, 6, e 18, indicam a importância que os acadêmicos dedicam ao fato de o professor estudar e aprender para ensinar, ou seja, no momento em que desenvolve uma atividade de ensino, ela pode se converter também em atividade de aprendizagem para o professor. Mas, para que a ação de estudar se converta em atividade, é preciso que tenha origem em uma necessidade e que seu motivo coincida com o objeto. De acordo com Leontiev (1978, p.107-108),

[...] toda atividade é dirigida por um motivo que procura atender às necessidades do sujeito. Uma necessidade só pode ser satisfeita quando encontra um objeto, ou seja, um motivo. O motivo é o que impulsiona uma atividade, pois articula uma necessidade a um objeto. Objetos e necessidades isolados não produzem atividade, a atividade só existe se há um motivo.

Logo, ao estudar para planejar a atividade, os acadêmicos não poderiam estar preocupados em simplesmente ler um texto para cumprir uma tarefa proposta pelo grupo. Ao contrário, assim como o indicativo de estudar partiu deles, esse movimento, como já constatado anteriormente, esteve motivado pela necessidade de aprender sobre o assunto, coincidindo com o objeto - apropriar-se dos conteúdos envolvidos - e, como consequência, conseguir planejar a atividade. Ou seja, a atividade de aprendizagem subsidiou a atividade de ensino, na medida em que a apropriaçáo do conhecimento matemático por parte dos futuros professores permitiu a posterior organização de uma Situação Desencadeadora de Aprendizagem, visando à apropriação dos conceitos pelas crianças. Acreditamos que é nessa perspectiva que a AOE pode constituir-se como unidade formadora do professor e do aluno.

\section{Considerações sobre a aprendizagem dos futuros professores}

Buscando contemplar o objetivo inicialmente proposto de discutir a aprendizagem da docência de futuros professores, pautados nos pressupostos teóricos já explicitados, apontamos dois aspectos que evidenciamos e que orientaráo as consideraçóes que teceremos a partir dos episódios apresentados. Tais aspectos entrelaçam-se e dizem respeito à necessidade dos futuros professores de estudar sobre o conteúdo a ser ensinado e o sentido atribuído por eles a essa ação.

No decorrer dos diálogos dos dois episódios, as discussóes levaram os acadêmicos a concluir sobre a importância de estudar para apropriar-se do conhecimento matemático que iriam ensinar, atribuindo-lhe um caráter de 
pressuposto para planejar. Ou seja, o motivo deu um novo sentido ao estudar, agora, relacionado à organizaçáo do ensino.

Ao produzir novos motivos no decorrer da própria atividade o professor também passa a atribuir novos sentidos a ela, o que inclui novos sentidos às suas açôes, aos instrumentos que escolher e ao processo de trabalho coletivo que criou condiçôes para as mudanças percebidas. (MORETTI, 2007, p. 121).

Sobre os motivos, Leontiev (1978) apresenta dois tipos: os motivos apenas compreensíveis e os motivos realmente eficazes, geradores de sentido. O motivo é compreensível quando é externo à atividade do sujeito, funciona como um estímulo e é apenas compreendido pelo sujeito. Porém, os motivos são eficazes na medida em que geram um sentido pessoal ao sujeito em atividade. Nessa perspectiva, Leontiev destaca e aprecia o papel da escola e do professor na transformaçáo de motivos e no desenvolvimento psíquico.

Muitas atividades podem ter, inicialmente, motivos apenas compreensíveis. Entretanto, a partir dos resultados das suas açôes, vão se tornando motivos eficazes. No nosso trabalho, nas reflexóes sobre a SDA da Atividade Rapunzel, foi possível observar três pontos em que houve mudança a partir de motivos geradores de sentido e atribuição de novos sentidos pelos acadêmicos: a compreensão de que, ao trabalhar com grandezas e medidas, a primeira SDA a ser proposta deve ser sobre o conceito de medir; a percepção de que o estudo para a atividade realizada anteriormente não havia sido suficiente; e a conclusão de que não é qualquer referencial teórico que lhes pode subsidiar o estudo e permitir a apropriaçáo da essência do conceito a ser trabalhado.

Ainda ao discutir sobre a SDA da Atividade da Rapunzel, nos dois episódios, a ação de estudar, decorrente das reflexóes, ficou bem marcada como oriunda de uma necessidade explicitada nas falas dos acadêmicos em vários momentos: a apropriação de conhecimentos para organizar o ensino.

A partir disso, é possível dizer que o conhecimento a que se referem os acadêmicos diz respeito tanto ao conceito matemático em questáo quanto aos aspectos relevantes para a efetivaçáo de um trabalho pedagógico que leve os alunos a aprender. Portanto, a necessidade de estudar e organizar o estudo também reflete no grupo a "necessidade de criar situaçóes que permitam aos sujeitos estabelecerem apropriaçóes das objetivaçóes humanas produzidas historicamente." (MORETTI, 2007, p. 48). Acreditamos que os indivíduos possam interagir e apropriar-se da cultura elaborada pelo homem em diferentes contextos e, por isso, concordamos com Moura (2001) quando aponta que é no processo de educaçẫo escolar que acontece a apropriação de conhecimentos ligados à intencionalidade social. 
Sobre a apropriação e a apresentação do conhecimento matemático nas ações dos acadêmicos, em especial nas falas relatadas nos episódios, eles próprios indicam que a sua bagagem de estudos matemáticos é insuficiente para bem desempenhar o papel de professores. Essa Matemática é oriunda da sua formação, seja na Educação Básica ou na formação inicial como educadores, e mostra-se deficitária, ao pensar em como ensiná-la para as crianças. E isso fica evidente tanto nos alunos da Licenciatura em Matemática quanto nos da Pedagogia. A possibilidade de integrar um grupo de estudos e pesquisas que se volte para essas preocupaçóes é uma oportunidade de refletir sobre essas dificuldades, embora tal processo de estudo, discussão e organização do ensino possa consolidar-se como recorrente na sua prática.

A prática do estudo coletivo faz parte da dinâmica do nosso grupo, de modo que o planejamento das atividades também acontece de forma compartilhada e intencional a partir desse estudo. O referido pressuposto decorre da ideia de Vigotsky (1994) de que as funçóes psicológicas superiores se desenvolvem a partir das relaçóes sociais que o indivíduo estabelece com o mundo. Ou seja, resultam da relação entre as pessoas, para depois serem interiorizadas. Assim, acreditamos que esse movimento favoreça o desenvolvimento e a aprendizagem da docência de cada indivíduo, como parte de um grupo que possui as mesmas preocupaçóes e os mesmos interesses. Apontamos a importância de que essa prática de organização do ensino compartilhada ocorra em todos os espaços escolares, conforme Moura (2001, p. 157) discute:

As atividades de ensino, portanto, deveriam ser fruto de acordos coletivos sobre os fins da educaçáo que se quer. A intencionalidade educativa é, no seu nascedouro, o resultado de múltiplos fatores que se unem num propósito coletivo de querer influenciar ou modificar comportamentos. E esta modificação por sua vez poderá servir para alterar algum aspecto da realidade, graças à aprendizagem sobre como realizar açôes concretas, tais como: construir uma ferramenta, realizar uma intervenção cirúrgica ou construir estradas. $\mathrm{Ou}$ seja, as intencionalidades educativas proporcionaráo mudanças em sujeitos que adquirem novas competências, comportamentos e valores e, na realidade objetiva, como resultado das açôes desses sujeitos.

Todavia, para organizar o ensino de forma coletiva, na perspectiva apontada, levantamos uma outra questão: qual é o conhecimento matemático que o professor precisa para organizar e desenvolver seu trabalho? As falas dos acadêmicos indicam que eles esperam realizar um estudo que lhes permita compreender a essência dos conceitos que irão trabalhar com as crianças. Entretanto, o enfoque do conteúdo descontextualizado do seu movimento lógico-histórico ou ainda o simples relato 
de um fato histórico não será suficiente para essa aprendizagem. É necessário um estudo que permita compreender a relação entre o lógico e o histórico do conceito. O histórico corresponde ao processo com as etapas de surgimento e desenvolvimento do conhecimento matemático, enquanto o lógico representa "o estudo da estrutura, dos meios de demonstração, do surgimento e evolução de uma teoria científica" (KOPNIN, 1978, p.21) - de certa forma, uma apropriação dos aspectos históricos pelo pensamento do homem.

\begin{abstract}
À base do conhecimento da dialética do histórico e do lógico resolve-se o problema da correlaçáo entre o pensamento individual e o social; em seu desenvolvimento intelectual individual o homem repete em forma resumida toda a história do pensamento humano. (KOPNIN, 1978, p. 186).
\end{abstract}

No dizer do autor já referido, "para revelar a essência do objeto é necessário reproduzir o processo histórico real de seu desenvolvimento, mas este é possível somente se conhecemos a essência do objeto." (KOPNIN, 1978, p.184). Assim sendo, a compreensão do processo lógico-histórico do conceito é importante ao desenvolvermos um trabalho pedagógico fundamentado na THC, em que a lógica do conceito e a sua construção humana histórica caminham juntas.

Por fim, destacamos que, no processo de organização do ensino, a necessidade de elaborar as açôes a serem desenvolvidas pelos alunos pode mobilizar a aprendizagem da docência a partir da apropriaçáo de novos conhecimentos relativos aos conteúdos e aos conceitos que serão trabalhados em sala de aula. Dessa forma, os conhecimentos matemáticos adquiridos pelos acadêmicos e utilizados durante suas açôes, a partir da dinâmica do grupo, permitiram a organização e o desenvolvimento da prática pedagógica na escola. Para além disso, consideramos que lhes permitiram também construir um modo geral de organizaçáo do ensino que poderá ser utilizado em outros momentos, na solução de problemas e em novas atividades escolares.

\title{
Referências
}

D'AMBROSIO, U. Da realidade à ação: reflexôes sobre educação e matemática. São Paulo: Summus, 1986.

KOPNIN, P. V. A dialética como lógica e teoria do conhecimento. Rio de Janeiro: Civilização Brasileira, 1978.

LEONTIEV, A. N. O desenvolvimento do psiquismo. São Paulo: Moraes, 1978. 
Actividad, consciência, personalidad. 2. ed. Habana: Pueblo y Educación, 1983.

LOPES, A. R. L. V. Aprendizagem da docência em matemática: o Clube de Matemática como espaço de formação inicial de professores. Passo Fundo: Ed. Universidade de Passo Fundo, 2009.

MORETTI, V. D. Professores de Matemática em atividade de ensino: uma perspectiva histórico-cultural para a formação docente. 2007. Tese (Doutorado em Educação) - Faculdade de Educação da Universidade de São Paulo, São Paulo, 2007.

MOURA, M. O. de. Construçáo do signo numérico em situaçáo de ensino. Tese (Doutorado em Educação) - Faculdade de Educação, Universidade de São Paulo, São Paulo, 1992.

A atividade de ensino como unidade formadora. Bolema, Rio Claro, v. 12, p.29-43, 1996.

O educador matemático na coletividade de formaçáo: uma experiência com a escola pública. Tese (Livre-Docência) - Faculdade de Educação, Universidade de São Paulo, São Paulo, 2000.

A atividade de ensino como açáo formadora. In: CASTRO, A. D. de; CARVALHO, A. M. P. de (Org.). Ensinar a ensinar: didática para a escola fundamental e média. São Paulo: Pioneira Thompson Learning, 2001. p. 143-162.

Pesquisa colaborativa: um foco na açáo formadora. In: BARBOSA, R. L. L. (Org.) Trajetórias e perspectivas da formação de educadores. São Paulo: Editora Unesp, 2004. Cap. 18, p. 257-284.

MOURA, M. O. et al. A atividade orientadora de ensino como unidade entre ensino e aprendizagem. In: MOURA, M. O. (Org.). A atividade pedagógica na teoria histórico-cultural. Brasília: Liber Livro, 2010.

VIGOTSKY, L. S. A formaçáo social da mente: o desenvolvimento dos processos psicológicos superiores. São Paulo: Martins Fontes, 1994.

Fontes, 2000.

A construçáo do pensamento e da linguagem. São Paulo: Martins - Uma contribuiçáo à teoria de desenvolvimento da psique infantil. In: VIGOTSKII, L. S.; LURIA, A. R; LEONTIEV, A. N. Linguagem, desenvolvimento e aprendizagem. 2.ed. São Paulo: Ícone, 2001. p. 59-83.

Recebimento em: 09/08/2015.

Aceite em: 15/12/2015. 


\section{Notas de leituras, resumos e resenhas}





\title{
Educação e Democracia: as lições da Finlândia para o Brasil
}

\author{
Education and Democracy: \\ the learning of Finland in Brazil
}

SAHLBERG, Pasi. Lições Finlandesas 2.0: o que a mudança educacional da Finlândia pode ensinar ao mundo? Tradução de Elena Gaidano. São Paulo: SESISP Editora, 2018. 320 p.

Camila EMÍlIO' Marineide de Oliveira GOMES²

Pasi Sahlberg iniciou sua carreira como professor de matemática e física no ensino básico da Finlândia e exerceu a docência em Universidades. Atualmente é professor de Política Educacional no Instituto Gonski de Educação da Universidade de New South Wales, em Sydney, na Austrália e foi ganhador, com a obra, do Prêmio Grawemeyer, em 2013. O livro resulta de síntese de dez anos de análises políticas e de experiências como professor e gestor educacional, além dos diálogos com milhares de educadores pelo mundo.

Sahlberg conta, nesse livro, como o sistema educacional da Finlândia essencialmente público, em todos os níveis - que era considerado medíocre nos anos 1980, tornou-se um modelo exitoso e motivo de cobiça por outros países, contextualizando as reformas educacionais que abrangeram não apenas o campo da educação, mas a política e a sociedade finlandesa. Ressal ta a lentidão das mudanças educacionais com vistas à sua efetividade e a necessidade de tais mudanças envolverem e serem assumidas pelo conjunto da sociedade. No caso da Finlândia isso ocorreu ao longo de três décadas de reformas e ajustes, o que teve como consequência, entre outros aspectos, os resultados positivos

1 Professora de Artes e mestranda do Programa de Pós-Graduação em Educaçáo (PPGE) da Universidade Católica de Santos. E-mail: <camilaemilio@gmail.com>.

2 Doutora em Educaçáo (FE-USP), com pós-doutoramento pela Univ. Católica Portuguesa (Lisboa) e professora do Programa de Pós-Graduação em Educaçáo (PPGE) da Universidade Católica de Santos. E-mail: <neide.ogomes@gmail.com>.

R. Educ. Públ.

Cuiabá

v. 28

n. 67

p. $241-244$

jan./abr. 2019 
nos exames internacionais (aspecto da educação finlandesa que se tornou mais visível para o mundo).

A obra está dividida em breve Introdução, seguida de cinco capítulos. No início, o autor aborda o desafio de preparar os jovens para o mundo do trabalho do futuro, ilustrando com uma expressão alarmante de um ex-presidente da Finlândia de que nos próximos dez anos haverá no mundo cerca de um bilhão de jovens entre 15 e 30 anos sem emprego. No primeiro capítulo, "O sonho Finlandês: uma boa escola para todos", o autor traz um panorama histórico sobre a Finlândia pós-guerra e como ocorreu o processo de reestruturação política, econômica e educacional, importante para o entendimento da situação educacional finlandesa atual em que a associação de professores finlandesa de educação primária teve papel fundamental na criação do sistema educacional público nos anos 1970. No segundo capítulo: 'Paradoxo finlandês: menos é mais', fica evidenciada a estabilidade no ensino finlandês, comprovadamente bem-sucedida, sobretudo pelo uso de estratégias alternativas de desenvolver bons sistemas públicos de educação que diferenciem daqueles oferecidos nos fóruns mundiais de Políticas Educacionais.

O capítulo 3 intitulado: 'A vantagem finlandesa: os professores', se atribui a estes profissionais parcela considerável do êxito alcançado pela educação na Finlândia, demarcando na história da formação dos professores daquele país, um episódio significativo em 1979, no contexto de uma reforma educacional, em que os professores foram desafiados ao uso de métodos instrucionais alternativos e de desenvolverem ambientes de aprendizagem para um ensino diferenciado, aliado à exigência de melhoria na qualificação profissional docente, com o oferecimento de cursos gratuitos de pós-graduação. $\mathrm{O}$ autor ressalta a necessidade de autonomia relativa das escolas em gerir seus projetos educacionais e a importância da confiança nos professores para propor mudanças no cotidiano escolar, elaborar e utilizar alternativas diferenciadas de ensino.

No capítulo 4, 'A via finlandesa: estado competitivo de Bem-estar social', -fica evidenciada a importância do grau de desenvolvimento em outras áreas setoriais para haver sucesso no sistema educacional, com bons índices em áreas como comércio, tecnologia, igualdade de gênero, bem-estar infantil, boa governança e sobretudo, uma adequada estrutura de saúde e emprego para todos. O último capítulo traz uma pergunta: 'O futuro, é finlandês?' Nele o autor reafirma alguns pontos positivos do ensino na Finlândia, discutidos no livro, com ênfase ao que considera ser o fundamental no trabalho dos professores: ajudar as crianças a aprender e prestar atenção nas suas necessidades, o que se apresenta como sentido do trabalho docente. Dentre as propostas do autor para se atingir a excelência de ensino, a mais valiosa de todas, é que uma educação democrática só acontecerá em um país consolidado democraticamente. 
A profissão docente (em sua maioria exercida por mulheres) é hoje a mais concorrida do país. O desejo pela profissão na Finlândia chega a 98\% dos estudantes aptos a concorrerem à vaga. Os salários dos professores finlandeses são equiparados aos salários de outras profissôes prestigiadas, sendo que o fator que atrai os jovens professores é a autonomia profissional, vez que boa parte dos professores finlandeses desistiria da profissão, caso precisasse cumprir metas estabelecidas por avaliaçóes e exames externos. A construção social e as imagens interna e externa da profissão docente contribuem assim para gerar uma motivação crescente nos professores.

O tempo diário de aula dos estudantes e dos professores finlandeses é inferior à média dos países que estão no topo das avaliaçóes internacionais (média de 20 horas semanais), o que contraria a ideia de que um tempo maior de estudantes e professores na escola representa maior aprendizagem dos estudantes. Das áreas curriculares há a prioridade para a leitura e a escrita com reflexos sociais: a populaçáo finlandesa lê assiduamente, sendo que dois de cada três adultos na Finlândia são bons ou excelentes leitores.

Com a política educacional finlandesa de prioridade à educação e de valorização de professores, a Finlândia caminha em sentido contrário às Políticas Educacionais globais pois não existe concorrência entre as escolas, nem há padronização da educação, as prestaçóes de contas não se pautam pelos testes em larga escala e o foco em disciplinas essenciais do currículo não subestima as demais áreas do conhecimento. A valorização profissional dos professores levouos à criação de políticas alternativas de estímulo das crianças e jovens visando um desenvolvimento humano e integral. $\mathrm{O}$ sucesso nos testes padronizados internacionais resulta de consequência natural do sucesso de Políticas Públicas Educacionais que priorizam a educação pública e é alimentado pelos diferentes atores educacionais e pela sociedade que têm a educação como valor.

$\mathrm{O}$ autor discute a função social da educação básica em um país democrático que ao longo de três décadas construiu socialmente um pacto pela educação pública, com uma perspectiva integrada e sistêmica, pela valorização e promoção da autonomia das escolas e dos professores, de modo a formar o estudante para os desafios da vida, de forma global e articulada.

Em relaçáo ao baixo desempenho educacional do Brasil (ocupando a 60a posição - dentre 76 países, na avaliação do teste Pisa, realizada em 2015), escolhemos ir ao ponto que julgamos fundamental para que a educação entre nós alce patamares dignos e que seja reveladora de reais aprendizagens para todos os envolvidos nos processos educacionais e que é reforçado pelo autor: a necessidade de democracias consolidadas para o êxito educacional, exercida por uma boa governança política em todas as esferas, entendida a educação como 
bem público. Tal condição, ao nosso ver, se configura como peça-chave para a compreensão do sistema educacional brasileiro em que as disputas históricas entre o público-privado se intensificam, sempre que os privilégios das grandes corporaçóes se veem ameaçadas. Ao mesmo tempo as 'lições da Finlândia' lançam luzes sobre possibilidades de melhoria na educação que temos, se considerarmos a apropriação pela sociedade das Políticas Educacionais por meio do conceito de governança pública, pautado nos princípios do controle do Estado (interno e externo) e da sociedade, pelo estímulo à transparência, à equidade, à justiça e à accountability (prestação de contas com responsabilidade pública).

No Brasil, país de profundas desigualdades sociais que se polariza entre as carências e os privilégios, o campo da Educação tem pouco a avançar se as condiçóes básicas de vida da população, em geral, não evoluir, se a profissão docente não conquistar outro status de reconhecimento social (o que não se faz da noite para o dia), se a educação não for entendida como processo e não medida somente por resultados de avaliações externas, que não dialogam com a realidade das escolas e dos professores e se não for enfrentado o cartel dos grandes grupos econômicos financistas que pautam as Políticas Públicas Educacionais e ameaçam o direito à educação (entre outros aspectos). No que se refere à consolidaçáo democrática, as ameaças à democracia no país se fazem presentes ao longo da nossa história (do processo de colonização do país aos dias atuais). Os avanços sociais observados nas últimas décadas náo estão consolidados, ao contrário, as características básicas da sociedade brasileira calcadas no patrimonialismo e no clientelismo continuam a reforçar a tutela e o favor nas relaçóes entre Estado, governo e sociedade e prestam um des-serviço na perspectiva da educação como direito.

Das 'lições da Finlândia', o dever de casa da educação pública no Brasil - fruto de processo democrático - ainda está por ser feito... 


\section{Informes da pós-graduação e da pesquisa}





\title{
Seminário Educação 2018: 30 Anos do Programa de Pós-graduação em Educação - Diálogos entre Políticas Públicas, Formação de Professores e Educação Básica
}

\author{
Seminar on Education 2018: 30 Years of the Post-graduate \\ Program in Education - Dialogue between Public Policies, \\ Teacher Training and Basic Education
}

Filomena Maria de Arruda MONTEIRO'

Durante o Seminário Educação 2018 (SEMIEDU), realizado entre os dias 4 a 7 de novembro de 2018, na Universidade Federal de Mato Grosso/UFMT, em que se comemorou os 30 anos do Programa de Pós-Graduaçáo em Educaçáo - PPGE, o diálogo entre Políticas Públicas, Formação de professores e Educação Básica esteve em foco nos diferentes momentos do evento. Criado em 1987, o Programa de Pós-Graduação em Educação/Instituto de Educação-PPGE, passa a ser o primeiro programa stricto sensu do estado, iniciando suas atividades de pósgraduação em 1988. Nesta edição, o evento contou com a coorganizaçáo da linha "Organização Escolar Formação e Práticas Pedagógicas" mais especificamente, o grupo de Estudos Pesquisas em Política e Formação Docente (GEPForDoc) que tem se caracterizado no desenvolvimento de estudos no âmbito da educação formal, realizando uma interlocução sistemática com várias áreas do saber, entre elas a Didática, o Currículo, a Formação de Professores, as Políticas Públicas e a Profissão Docente, referenciados na ciência política, na sociologia, na antropologia, na psicologia social e educacional, na filosofia e na história.

O evento se revestiu de relevância devido ao elevado número de participantes, ao grande número de trabalhos submetidos e ao excelente nível das palestras e conferências realizadas. Foram inscritos no evento 786 profissionais da educação básica, 372 alunos da graduação, 132 pesquisadores e 279 pós-graduandos, que puderam apresentar seus trabalhos e compartilhar suas experiências com elevados ganhos sociais. Estiveram presentes também participantes e conferencistas de diversos países, como Espanha, México, Colômbia, Argentina, Venezuela, Chile,

1 Vice-coordenadora do Programa de Pós-graduação em Educação PPGE-UFMT, coordenadora geral do Seminário Educação 2018 (SEMIEDU). E-mail: <filarruda@hotmail.com>. 
e Guiné-Bissal, demonstrando sintonia com o processo de internacionalização em curso na UFMT e no PPGE. Foram realizadas ainda reunióes e tratado de projetos em pareceria, em âmbito nacional e internacional.

A conferência de abertura intitulada "Os professores e os desafios das diversidades e das migrações: formação, currículo e políticas educativas" foi proferida por José Gonzales Monteagudo (Universidad de Sevilla).

A temática de Políticas Públicas, Formação de Professores e Educação Básica, foi contemplada também, em duas mesas com discussóes específicas sobre a pósgraduação "Perspectivas e desafios da Pós-graduação em Educação no Brasil" e "Pesquisa na Pós-graduação em Educação". Nessas mesas contamos com a participação de Andréa Barbosa Gouveia - UFPR; Maria de Fátima Cardoso Gomes - UFMG; João Ferreira de Oliveira - UFG; Maritza Maciel Castrillon Maldonado - UNEMAT; e Wander Miguel de Barros - IFMT. Tais debates colaboram na constituição de um momento de intensa reflexão para todos os envolvidos na pós-graduação em Educação no PPGE, e, também, ampliou possibilidades para perspectivar seu avanço, baseado no diálogo com a educação pública, com os movimentos sociais, e a configuração de novas redes nacionais e internacionais de pesquisa. 


\title{
Relação das defesas de Mestrado e Doutorado realizadas no PPGE/UFMT no período acadêmico 2018/2
}

\author{
Quadro 1 - Mestrado
}

\begin{tabular}{|c|c|c|c|}
\hline Título & Autor & Banca & Data \\
\hline $\begin{array}{l}\text { "Treinamento em Serviço: } \\
\text { formação de professoras e } \\
\text { professores não titulados } \\
\text { no Projeto Logos II em } \\
\text { Alta Floresta, Mato Grosso } \\
(1980-1993) "\end{array}$ & $\begin{array}{l}\text { Rosemary da } \\
\text { Luz }\end{array}$ & $\begin{array}{l}\text { Profa. Dra. Nilce Vieira } \\
\text { Campos Ferreira; Profa. Dra. } \\
\text { Marlene Gonçalves; Prof. } \\
\text { Dr. Josemir Almeida Barros; } \\
\text { Profa. Dra. Oresta López } \\
\text { Pérez; Profa. Dra. Márcia dos } \\
\text { Santos Ferreira. }\end{array}$ & 29/10/2018 \\
\hline $\begin{array}{l}\text { "A imagem de afirmação } \\
\text { de professoras da educação } \\
\text { básica: uma discussão mediada } \\
\text { pela dimensão pedagógica do } \\
\text { cinema negro" }\end{array}$ & Agnaldo Périgo & $\begin{array}{l}\text { Prof. Dr. Celso Luiz Prudente; } \\
\text { Prof. Dr. Neudson Johnson } \\
\text { Martinho; Prof. Dr. Luiz Felipe } \\
\text { de Alencastro; Prof. Dr. Silas } \\
\text { Borges Monteiro. }\end{array}$ & $08 / 11 / 2018$ \\
\hline $\begin{array}{l}\text { "Quilombo Itambé: saberes e } \\
\text { fazeres dos professores da área } \\
\text { de linguagem, código e suas } \\
\text { tecnologias" }\end{array}$ & $\begin{array}{l}\text { Silvana Alves } \\
\text { dos Santos }\end{array}$ & $\begin{array}{l}\text { Profa. Dra. Suely Dulce de } \\
\text { Castilho; Profa. Dra. Nilce } \\
\text { Vieira Campos Ferreira; } \\
\text { Prof. Dr. José Mauricio Paiva } \\
\text { Andion Arruti; Prof. Dr. Darci } \\
\text { Secchi. }\end{array}$ & $30 / 11 / 2018$ \\
\hline $\begin{array}{l}\text { "As Tecnologias de } \\
\text { informação e comunicação } \\
\text { como mediadoras na } \\
\text { aprendizagem significativa } \\
\text { do conceito de função numa } \\
\text { escola da Colômbia" }\end{array}$ & $\begin{array}{l}\text { Oscar Orlando } \\
\text { Hoyos Gaviria }\end{array}$ & $\begin{array}{l}\text { Profa. Dra. Marta Maria } \\
\text { Pontin Darsie; Prof. Dr. } \\
\text { Alexandre Martins dos Anjos; } \\
\text { Profa. Dra. Jacqueline Borges } \\
\text { de Paula; Profa. Dra. Irene } \\
\text { Cristina de Mello. }\end{array}$ & $06 / 12 / 2018$ \\
\hline $\begin{array}{l}\text { "Metacognição no Ensino- } \\
\text { Aprendizagem de Porcentagem } \\
\text { na Educação de Jovens e } \\
\text { Adultos" }\end{array}$ & $\begin{array}{l}\text { Mariana } \\
\text { Figueira } \\
\text { Secafim }\end{array}$ & $\begin{array}{l}\text { Profa. Dra. Marta Maria } \\
\text { Pontin Darsie; Profa. Dra. Rute } \\
\text { Cristina Domingos da Palma; } \\
\text { Profa. Dra. Kátia Maria de } \\
\text { Medeiros; Profa. Dra. Mariuce } \\
\text { Campos de Moraes. }\end{array}$ & $10 / 12 / 2018$ \\
\hline $\begin{array}{l}\text { "O uso de estratégias } \\
\text { metacognitivas na resolução } \\
\text { de problemas matemáticos por } \\
\text { alunos do } 8^{\circ} \text { ano do ensino } \\
\text { fundamental de uma escola } \\
\text { pública de MT" }\end{array}$ & $\begin{array}{l}\text { Luciane } \\
\text { Reichert Costa }\end{array}$ & $\begin{array}{l}\text { Profa. Dra. Marta Maria } \\
\text { Pontin Darsie; Profa. Dra. } \\
\text { Gladys Denise Wielewski; } \\
\text { Profa. Dra. Eliana Alves } \\
\text { Pereira Leite; Prof. Dr. } \\
\text { Adelmo Carvalho da Silva. }\end{array}$ & $11 / 12 / 2018$ \\
\hline
\end{tabular}




\begin{tabular}{|c|c|c|c|}
\hline Título & Autor & Banca & Data \\
\hline $\begin{array}{l}\text { "Planejamento escolar na } \\
\text { Educação Física: concepção } \\
\text { de professores iniciantes ex- } \\
\text { participantes do PIBID" }\end{array}$ & $\begin{array}{l}\text { Elaine Cristina } \\
\text { Silva }\end{array}$ & $\begin{array}{l}\text { Prof. Dr. Evando Carlos } \\
\text { Moreira; Prof. Dr. José } \\
\text { Tarcísio Grunennvaldt; } \\
\text { Prof. Dr. António Camilo } \\
\text { Teles Nascimento Cunha; } \\
\text { Profa. Dra. Marcia Cristina } \\
\text { Rodrigues da Silva Coffani. }\end{array}$ & $12 / 12 / 2018$ \\
\hline $\begin{array}{l}\text { "A Literatura no Currículo } \\
\text { dos Anos Iniciais do Ensino } \\
\text { Fundamental em Vilhena-RO" }\end{array}$ & $\begin{array}{l}\text { Adriana Silva } \\
\text { da Costa }\end{array}$ & $\begin{array}{l}\text { Profa. Dra. Ozerina Victor de } \\
\text { Oliveira; Profa. Dra. Bárbara } \\
\text { Cortella Pereira de Oliveira; } \\
\text { Profa. Dra. Geniana dos } \\
\text { Santos; Profa. Dra. Candida } \\
\text { Soares da Costa; Profa. Dra. } \\
\text { Celeida Maria Costa de } \\
\text { Souza e Silva. }\end{array}$ & $14 / 12 / 2018$ \\
\hline $\begin{array}{l}\text { "Compreensão da Leitura de } \\
\text { alunos do Ensino Médio: um } \\
\text { estudo com o teste Cloze" }\end{array}$ & $\begin{array}{l}\text { Renata } \\
\text { Francisca } \\
\text { Ferreira Lopes }\end{array}$ & $\begin{array}{l}\text { Profa. Dra. Tatiane Lebre } \\
\text { Dias; Profa. Dra. Bárbara } \\
\text { Cortella pereira de Oliveira; } \\
\text { Profa. Ângela Rita Christofolo } \\
\text { de Mello; Prof. Dr. José } \\
\text { Tarcísio Grunennvaldt. }\end{array}$ & $18 / 12 / 2018$ \\
\hline
\end{tabular}

Fonte: Programa de Pós-graduação em Educação, nov. 2018. 


\section{Quadro 2 - Doutorado}

\begin{tabular}{|c|c|c|c|}
\hline Título & Autor & Banca & Data \\
\hline $\begin{array}{l}\text { "Leitores e e-books: } \\
\text { novas formas de leitura } \\
\text { e suas aquisições" }\end{array}$ & $\begin{array}{l}\text { Carlos Henrique } \\
\text { Tavares de Freitas }\end{array}$ & $\begin{array}{l}\text { Profa. Dra. Kátia Morosov } \\
\text { Alonso; Prof. Dr. Cristiano } \\
\text { Maciel; Prof. Dr. Danilo } \\
\text { Garcia da Silva; Profa. Dra. } \\
\text { Edenar Souza Monteiro; } \\
\text { Profa. Dra. Maristela Abadia } \\
\text { Guimarães; Profa. Dra. } \\
\text { Terezinha Fernandes Martins } \\
\text { de Souza; Profa. Dra. Ana } \\
\text { Lara Casagrande. }\end{array}$ & $18 / 07 / 2018$ \\
\hline $\begin{array}{l}\text { "Sentidos e } \\
\text { significados da } \\
\text { educação física } \\
\text { para os alunos do } \\
\text { IFMT - Campus São } \\
\text { Vicente: a pesquisa- } \\
\text { ação como forma de } \\
\text { construção coletiva de } \\
\text { conhecimentos" }\end{array}$ & $\begin{array}{l}\text { Larissa Beraldo } \\
\text { Kawashima }\end{array}$ & $\begin{array}{l}\text { Prof. Dr. Evando Carlos } \\
\text { Moreira; Prof. Dr. José } \\
\text { Tarcísio Grunennvaldt; Prof. } \\
\text { Dr. Cleomar Ferreira Gomes; } \\
\text { Profa. Dra. Lílian Aparecida } \\
\text { Ferreira; Prof. Dr. Ricardo } \\
\text { Rezer; Profa. Dra. Tatiane } \\
\text { Lebre Dias; Prof. Dr. Felipe } \\
\text { Quintão de Almeida. }\end{array}$ & $30 / 11 / 2018$ \\
\hline $\begin{array}{l}\text { "O percurso } \\
\text { da Educação a } \\
\text { Distância na UFMT: } \\
\text { possibilidades e limites } \\
\text { do seu processo } \\
\text { de consolidação } \\
\text { institucional" }\end{array}$ & $\begin{array}{l}\text { Rosemery Celeste } \\
\text { Petter }\end{array}$ & $\begin{array}{l}\text { Prof. Dr. Cristiano Maciel; } \\
\text { Profa. Dra. Kátia Morosov } \\
\text { Alonso; Profa. Dra. Taciana } \\
\text { Mirna Sambrano; Profa. Dra. } \\
\text { Daniela da Costa Britto Pereira } \\
\text { Lima; Prof. Dr. Daniel Ribeiro } \\
\text { Silva Mill; Prof. Dr. Delarim } \\
\text { Martins Gomes; Profa. Dra. } \\
\text { Karine Nunes de Moraes. }\end{array}$ & $17 / 12 / 2018$ \\
\hline
\end{tabular}

Fonte: Programa de Pós-graduação em Educação, nov. 2018. 


\section{Diretrizes para autores}

\section{Normas para publicação de originais}

A Revista de Educação Pública - ISSN 0104-5962 - e-2238-2097 - é um periódico científico quadrimestral articulado ao Programa de Pós-Graduação em Educação (PPGE) da Universidade Federal de Mato Grosso (UFMT).

Aceita artigos, predominantemente, resultantes de pesquisa em educação, bem como ensaios e resenhas que privilegiem obras de relevância na área. Os ensaios destinam-se somente às questóes teóricas e metodológicas relevantes às seçóes. Estudos sobre o estado da arte acerca de temáticas voltadas ao campo educativo também são aceitos.

Os trabalhos recebidos para publicação são submetidos à seleção prévia do editor científico da seção a que se destina o texto. As seçôes estão circunscritas às seguintes temáticas: Cultura Escolar e Formação de Professores; Educação, Poder e Cidadania; Educação e Psicologia; Educação Ambiental; História da Educação; Educação em Ciências e Matemática.

A publicação de um artigo ou ensaio implica automaticamente a cessão integral dos direitos autorais à Revista de Educação Pública.

A exatidão das ideias e opiniōes expressas nos trabalhos são de exclusiva responsabilidade dos autores.

O autor deve indicar, quando for o caso, a existência de conflitos de interesse.

\section{Resenha}

Resenhas de livros devem conter 4 (quatro) páginas e respeitar as seguintes especificaçôes técnicas: título atribuído à resenha; subsequentemente, nas próximas linhas, apresentar dados bibliográficos completos da publicação resenhada; nome(s) do(s) autor(es) da resenha com informaçóes no pé da página sobre a formação e a instituição a que esteja vinculado. Informaçóes no texto ou referências que possam identificar o(s) autor(es) devem ser suprimidas e enviadas separadamente via documento suplementar. Uma vez aceito o trabalho, tais dados voltarão para o texto na revisão final. Comunicaçóes de pesquisa e outros textos, com a mesma quantidade de páginas serão publicados por decisão do Conselho Científico. Resenhas, informes ou comunicaçóes, com revisóes textuais devem conter título em inglês, ou francês ou em língua de origem. 


\section{Artigo}

Os procedimentos para análise e aprovação dos manuscritos centram-se em critérios como:

a. Máximo de três autores por artigo, sendo um deles necessariamente com título de doutor. Cada autor deverá aguardar um intervalo de dois anos para nova publicação.

b. A Introdução deve indicar sinteticamente antecedentes, propósito, relevância, pesquisas anteriores, conceitos e categorias utilizadas;

c. Originalidade (grau de ineditismo ou de contribuição teórico-metodológica para a seção a que se destina o manuscrito);

d. Metodologia (critérios de escolha e procedimentos de coleta e análise de dados);

e. Resultados (apresentar descrição clara dos dados e sua interpretação à luz dos conceitos e categorias);

f. Conclusão (exposição dos principais resultados obtidos e sua relação com os objetivos e limites);

g. A correção formal do texto (a concisão e a objetividade da redação; o mérito intrínseco dos argumentos; a coerência lógica do texto em sua totalidade);

h. O potencial do trabalho deve efetivamente expandir o conhecimento existente;

i. A pertinência, diversidade e atualidade das referências bibliográficas e cumprimento das normas da Associação Brasileira de Normas Técnicas - ABNT;

j. Conjunto de ideias abordadas, relativamente à extensão do texto e exaustividade da bibliografia pertinente é fundamental ao desenvolvimento do tema;

k. Como instrumento de intercâmbio a Revista prioriza mais de $70 \%$ de seu espaço para a divulgação de resultados de pesquisa externos à UFMT. São aceitos também artigos em idiomas de origem dos colaboradores.

1. Os artigos, incondicionalmente inéditos e resultantes de pesquisas empíricas devem ser submetidos à REVISTA DE EDUCAÇÃO PÚBLICA somente mediante cadastro realizado por meio deste mesmo endereço eletrônico: $<$ http://periodicoscientificos.ufmt.br/index.php/educacaopublica/about/ submissions\#authorGuidelines>

O Conselho Científico tem autonomia para decidir sobre publicação de artigos de convidados externos de alta relevância para as linhas de pesquisa vinculadas ao Programa de Pós-Graduação em Educação da UFMT. 


\section{Para submissão, devem ser observados os seguintes critérios:}

a. Título do artigo (conciso contendo no máximo 15 palavras). Utilizar maiúsculas somente na primeira letra, nomes próprios ou siglas. Título em Inglês entram logo após o título em português.

b. Resumo, em português, contendo até 100 palavras; digitado entrelinhas simples, ressaltando objetivo, método e conclusôes. Resumo em língua estrangeira também deverá ser entregue, preferencialmente em inglês (abstract);

c. Palavras-chave (até quatro palavras) devem ser esclarecedoras e representativas do conteúdo. Tratando-se de resumo em língua estrangeira deverão ser encaminhados o keywords, ou equivalente na língua escolhida;

d. Informaçóes no texto ou referências que possam identificar o(s) autor(es) devem ser suprimidas do texto e enviadas separadamente via documento suplementar. Uma vez aceito o trabalho, tais dados voltarão para o texto na revisão final.

Marcas de identificação do autor no texto, impossibilitarão o manuscrito de seguir para o trâmite de avaliação.

\section{Formatação}

Para a formataçáo do texto utilizar o processador o formato Word for Windows.

a. Digitar todo o texto na fonte Times New Roman, tamanho 12, com espaçamento entre linhas $1,5 \mathrm{~cm}$, inclusive nos parágrafos, margens superior/ esquerda 3,0 cm; margem direita/inferior 2,0 cm; papel A4.

b. Em caso de ênfase ou destaque no corpo do texto usar apenas itálico.

c. Para as citaçóes diretas com mais de três linhas, usar fonte 10, observando-se um recuo de $4 \mathrm{~cm}$ da margem esquerda. Utilizar 1 (um) espaço antes e depois de citação.

As citações devem obedecer a NBR 10520 (2002) da ABNT, indicadas no texto pelo sistema de chamada autor-data. As citaçôes diretas (transcriçóes textuais de parte da obra do autor consultado), de até três linhas, devem estar contidas entre aspas duplas indicadas por chamadas assim: (FREIRE, 1974, p. 57).

As citaçóes indiretas (texto baseado na obra do autor consultado) devem indicar apenas o autor e o ano da obra. 
d. As ilustraçóes e tabelas deverão ser enviadas no corpo do texto, claramente identificadas (Ilustração 1, Tabela 1, Quadro 1, etc., com respectivos títulos e devem ser alocadas na parte superior da ilustração/figura, bem como a inserção da fonte, deve ser inserida na parte inferior). No caso de fotografias, é necessário o nome do fotógrafo e autorização para publicação, assim como a autorização das pessoas fotografadas. Tais informações devem ser enviadas em documento suplementar da submissão.

As tabelas, figuras, fotos, ilustraçóes e diagramas a serem inseridos no corpo do texto deverão conter:

- Tamanho equivalente a mancha da página (12x18);

- Qualidade de impressão (300 dpi);

- Guardar legibilidade e definição.

Os artigos devem conter no mínimo 10 e máximo de 20 páginas. Necessariamente deverão ter passado por revisão textual.

As Referências, digitadas em ordem alfabética no final do texto, devem seguir a NBR 6023 (2002). Eis alguns casos mais comuns:

\section{LIVRO:}

FREIRE, P. Educaçáo como prática da liberdade. 4. ed. Rio de Janeiro: Paz e Terra, 1974. 150 p. (Série Ecumenismo e Humanismo).

\section{EVENTO:}

OLIVEIRA, G. M. S. Desenvolvimento cognitivo de adultos em educação a distância. In: Seminário Educação 2003. Anais... Cuiabá: UNEMAT, 2003, p. 22-24.

\section{ARTIGO EM PERIÓDICO:}

GADOTTI, M. A eco-pedagogia como pedagogia apropriada ao processo da Carta da Terra. Revista de Educaçáo Pública, Cuiabá, v. 12, n. 21, p. 11-24, jan./jun. 2003.

\section{DOCUMENTO COM AUTORIA DE ENTIDADE:}

MATO GROSSO. Presidência da Província. Relatório: 1852. Cuiabá, 20 mar. 1853. Manuscrito. 26 p. In: APMT, caixa 1852.

UNIVERSIDADE FEDERAL DE MATO GROSSO. Relatório: 2003, Cuiabá, 2004. $96 \mathrm{p}$. 
5. CAPÍTULO DE LIVRO:

FARIA FILHO, L. M. O processo de escolarização em Minas: questôes teóricometodológicas e perspectivas de análise. In: VEIGA, C. G.; FONSECA, T. N. L. (Org.). História e Historiografia da Educaçáo no Brasil. Belo Horizonte: Autêntica, 2003. p. 77-97.

\section{ARTIGO E/OU MATÉRIA DE REVISTA, BOLETIM E OUTROS EM MEIO ELETRÔNICO:}

CHARLOT, Bernard. A produçáo e o acesso ao conhecimento: abordagem antropológica, social e histórica. Revista de Educaçáo Pública, Cuiabá, v. 14, n. 25, jan./jun. 2005. Disponível em: <http://www.ie.ufmt.br/revista>. Acesso em: 10 nov. 2006.

As notas explicativas, restritas ao mínimo, deverão ser apresentadas no rodapé.

Revista de Educação Pública

Universidade Federal de Mato Grosso

Instituto de Educação, Revista de Educação Pública, Sala 101, térreo.

Av. Fernando Corrêa da Costa, 2.367, Boa Esperança, CEP 78.060-900

Cuiabá-MT, Brasil

Telefone: (65) 3615-8466

E-mail: <rep@ufmt.br>

Endereço eletrônico: <http://periodicoscientificos.ufmt.br/index.php/ educacaopublica/index> 


\section{Cultura Escolar e Formação de Professores}

Sentidos de qualidade: vozes de professores e estudantes egressos da EJA no Ensino Superior

Caroline de Moura ROSA • Sita Mara Lopes SANT' ANNA • Odilon Antônio STRAMARE

\section{Educação e Psicologia}

A presença dos jogos de papéis na Educação Infantil

Maria Lidia Sica SZYMANSKI • Lisiane Gruhn COLUSSI

Pesquisa com crianças: entre a experiência no campo e a escrita do texto

Irene Carrillo Romero BEBER - Maria Carmen Silveira BARBOSA

\section{Educação, Poder e Cidadania}

Diferenças, alteridade e construção de valores inclusivos

Sandrelena da Silva MONTEIRO

Aquarela brasileira: fantasmas melaninos, venenos melanômicos

Armando de Melo LISBOA

\section{Educação Ambiental}

Formação continuada em Educação Ambiental: uma proposta em movimento Raquel Fabiane Mafra ORSI - Antonio Fernando Silveira GUERRA

\section{História da Educação}

Cartas Sororales entre de dos mujeres intelectuales: Palma Guillen y Gabriela Mistral Oresta LÓPEZ PÉREZ

Reformas na educação profissional brasileira na década de 1990: consenso e hegemonia

Arão Davi OLIVEIRA • Celeida Maria Costa de SOUZA e SILVA

\section{Educação em Ciências e Matemática}

Ciência escolar e ciência fora da escola: opiniões e interesses de jovens brasileiros

Graciela S. OLIVEIRA • Nelio BIZZO

Aprendizagem da docência na formação inicial de professores: estudar para ensinar matemática Simone POZEBON • Anemari Roesler Luersen Vieira LOPES

Notas de leituras, resumos e resenhas

Educação e Democracia: as lições da Finlândia para o Brasil

Camila EMÍLIO - Marineide de Oliveira GOMES

Informes da pós-graduação e da pesquisa 